BNWL-1900

Volume 2

HIGH-LEVEL RADIOACTIVE WASTE MANAGEMENT ALTERNATIVES

SECTION 4: GEOLOGIC DISPOSAL.

May 1974

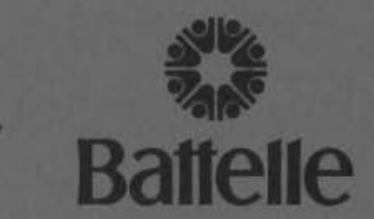

Pacific Northwest Laboratories

Richland, Washington 99352

Prepared for the U.S. Atomic Energy

Commission under Contract AT(45-1):1830 


\title{
NOTICE
}

The report was ptepared as an account of work sponsored by the United States Government. Neither the United States nor the United States Atomic Energy Commission, nor any of their employees, nor any of their contractors, subcontractors, of their employees, makes any warranty, express or implied, or assumes any legal liability or responsibility far the accuracy. completeness or usefuiness of any information, apparatus, product or process disciosed, or represents that its use would not intringe privately owned rights.

\author{
PACIFIC NORTHWEST LABORATORY \\ operated by \\ BATTELLE \\ for the \\ U.S. ATOMIC ENERGY COMMISSION \\ Under Contract AT(45-1)-1830
}

Printed in the United States of America

Available from

National technical Intormation Service

U.S. Department of Commerce

5205 Pont Royal Road

Springtield. Virginia 2215

Price: Printed Copy \$7 60: Microliche \$1.45

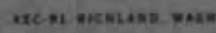




\section{HIGH-LEVEL RADIOACTIVE WASTE MANAGEMENT ALTERNATIVES}

SECTION 4: GEOLOGIC DISPOSAL

May 1974

Editors K. J. Schneider

A. M. Platt

Section 4 Contributors

M. R. Kreiter, Study Leader

K. J. Schneider, Study Leader

L. L. Ames

J. N. Hartley

G. Jansen

J. D. Kaser

J. R. Sheff

D. H. Stewart

D. D. Tillson

R. W. Wallace

W. K. Winegardner

G. A. Dinwiddie

E. B. Ekren

E. N. Hinrichs

J. W. Mytton

L. J. Schroder

W. Thordarson

J. E. Weir, Jr.

S. H. Woodcock

Fenix and Scisson Drilling Co. 


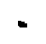

-

- 


\section{STUDY CONTRIBUTORS - TOTAL REPORT}

Following is a listing of the primary study contributors. Unless otherwise noted, they are affiliated with the Pacific Northwest Laboratory of Battelle Memorial Institute.

\section{Overall study Coordination}

K. J. Schneider

A. M. Platt

Background on High-Level Waste and Its Management

W. K. Winegardner, Study Leader

G. Jansen

Study Methodology and Safety Considerations

D. E. Deonigi, Study Leader

J. P. Corley, Study Leader

J. B. Burnham

T. I. McSweeney

D. H. Denham

D. A. Baker

J. K. Soldat

G. Jansen

R. C. Routson

Geologic Disposal Concepts

K. J. Schneider, Study Leader

M. R. Kreiter, Study Leader

R. W. Wallace

D. D. Tillson

W. K. Winegardner

J.R. Sheff

J. D. Kaser

J. N. Hartley

L. L. Ames

G. Jansen

D. H. Stewart

E. B. Ekren, USGS-Denver

G. A. Dinwiddie, USGS-Denver

J. W. Mytton, USGS-Denver

W. Thordarson, USGS-Denver

J. E. Weir, Jr., USGS-Denver

E. N. Hinrichs, USGS-Denver

L. J. Schroder, USGS-Denver

S. H. Woodcock

Fenix and Scisson Drilling Co.

Seabed Disposa 1 Concepts

R. W. Wallace, Study Leader

D. D. Tillson, Study Leader

W. H. Swift

J. R. Divine

P. J. Valent, Civil Engineering

H. J. Lee Laboratory, U.S.

D. G. True Naval Construction

R. J. Malloy Battalion Center
Ice Sheet Disposal Concepts
R. W. Wallace, Study Leader
D. D. Tillson, Study Leader
W. H. Swift
J. R. Divine

Extraterrestrial Disposal Concepts

K. Drumheller, Study Leader

C. L. Brown

B. Griggs

R. E. Hyland et a 1., NASA-Lewis

J. S. Mackay, NASA-Ames

D. R. O'Keefe, Gulf Energy \& Environmental Systems Company

Transmutation Elimination Concepts

R. C. Liikala, Study Leader

B. R. Leonard, Jr.

W. C. Wolkenhauer

D. L. Lessor

E. T. Merri11

T. I. McSweeney

J. B. Burnham

B. F. Gore

C. W. Lindenmeir

Waste Partitioning

R. E. Burns, Study Leader

J. W. Bartlett, Study Leader

L. A. Bray

L. L. Burger

J. L. Ryan

Waste Management Costs

R. W. Mckee, Study Leader

J.B. Burnham

S. A. Rao

R. D. Spil1man Automation Indus-

N. F. Stark $\}$ tries, Inc., Vitro Division

Policy Conflicts

J. B. Burnham

Public Response

J. B. Burnham, Study Leader

S. M. Nealey Human Affairs

W. S. Maynard\} Research Center, 
-

.

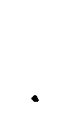

. 


\section{FOREWORD}

This report is a comprehensive overview study of potential alternative methods for long-term management of high-level radioactive waste. The study includes a compilation of information relevant to technical feasibility, safety, cost, environmental considerations, policy conflicts, public response and research and development needs for:

1. Disposal in terrestrial locations

a. In geologic settings on land

b. In the seabed

c. In ice sheets

2. Disposal into space

3. Elimination by transmutation (nuclear transformation of certain waste constituents into nuclides having less long-term toxicity).

The study is limited to the management of high-level radioactive waste from nuclear power by variations of these alternatives. Consideration of alternative types of electrical power generation are not within the scope of the study. In addition, evaluation of interim storage of radioactive waste in retrievable surface storage facilities is not part of this study. Disposal of waste in bedded salt deposits was studied extensively in other AEC programs, and the concept is included here as part of the overall matrix of geologic disposal techniques.

To complement these studies, investigations were also conducted on waste partitioning (separation of radionuclides in radioactive waste into different elements or groups of elements according to their long-term toxicity or suitability for different disposal methods), and systems methodology was developed to assess the effects of radionuclides from waste introduced into man's ecological cycle, assuming some failure of the primary waste containment.

Information pertinent to evaluating the various potential waste disposal techniques was developed without promoting any single disposal concept. The study is concerned with management of the waste and does not consider the potential for recovery of resources within the waste, including the heat. Concepts are developed only to the detail necessary to describe them for the overall investigation and in general are studied on a systematic, generic basis. This information can be used in comparing and assessing the various disposal concepts as a basis for decisions regarding their further study. 
The evaluations of feasibility are not restricted to currently available technology. Rather, the study attempts to take into account technology which can be developed or is expected to be available at least within the next four decades. Indeed, most of the concepts studied are estimated to require 15 to 30 years for full implementation.

The study includes most currently known waste management alternatives, but is not considered to be all-inclusive. As new data become available, and as new or varied concepts become evident (e.g., disposal in rocks in permafrost areas, isotopic dilution of selected materials, etc., ) comparable follow-on studies will be carried out.

This investigation has been performed largely by a multiple-discipline technical staff at the Pacific Northwest Laboratory of Battelle Memorial Institute with significant input from a large number of consultants and outside contributors. This wide involvement of persons was an attempt to assure up-to-date and accurate coverage of the broad scope of subject matter, including areas where there are diversities of opinions.

This report is issued as nine major sections in four volumes:

\begin{tabular}{|c|c|c|c|}
\hline \multirow{3}{*}{\multicolumn{2}{|c|}{ Volume 1}} & Section 1 & Summary $(a)$ \\
\hline & & Section 2 & Background and Data Base \\
\hline & & Section 3 & Evaluation Methodology \\
\hline Volume & 2 & Section 4 & Geologic Disposal \\
\hline \multirow[t]{2}{*}{ Volume } & 3 & Section 5 & Ice Sheet Disposal \\
\hline & & Section 6 & Seabed Disposal \\
\hline \multirow[t]{3}{*}{ volume } & 4 & Section 7 & Waste Partitioning \\
\hline & & Section 8 & Extraterrestrial Disposal \\
\hline & & Section 9 & Transmutation Processing \\
\hline
\end{tabular}

Appendix material is included with its own respective volume.

In general, metric system units are used in this report. Conversion factors to English units are given in Appendix 1.A.

a. This section is almost identical to WASH 1297, High-Level Radioactive Waste Management Alternatives, US AEC Division of Waste Management and Transportation, May 1974. 
ACKNOWLEDGMENTS - TOTAL REPORT

This study, performed over a period of about 1.5 years, received significant support from many people who are not 1 isted as key contributors. The contributions of these persons are gratefully acknowledged. Although the total of such participants is too numerous to mention, the following 1 ist shows many of the major contributors.

\section{Program Guidance, Funding and Review}

F. K. Pittman

U.S. A.E.C., Division of Waste

A. F. Perge

Management and Transportation

U.S.A.E.C., Division of Waste Management and Transportation

R. W. Ramsey

U.S.A.E.C., Division of Waste

H. F. Soule

Management and Transportation

U.S. A.E.C., Division of Waste

Management and Transportation

0. J. Elgert

U.S. A.E.C., Richland office

R. B. Goranson

U.S.A.E.C., Richland office

N. T. Karagianes

U.S. A.E.C., Richland office

R. D. Fogerson

U.S.A.E.C., Richland office

Overal1 Review

G. H. Daly

U.S. A.E.C., Division of Waste Management and Transportation

M. Skalka

U.S.A.E.C., Division of Waste

R. D. Walton

- Management and Transportation

U.S.A.E.C., Division of Waste Management and Transportation

W. K. Eister

U.S. A.E.C., Division of Waste

A. F. Kluk Management and Transportation

U.S. A.E.C., Division of Waste

V. G. Trice

Management and Transportation

U.S. A.E.C., Division of Waste Management and Transportation

T. L. Duncke 1

U.S. A.E.C., Division of Waste

Management and Transportation

C. L. Osterberg

U.S. A.E.C., Division of Biomedica 1 and Environmental

Research

H. M. Parker

Battelle, Pacific Northwest

Laboratory
C. M. Unruh

Battelle, Pacific Northwest Laboratory

R. F. Foster Battelle, Pacific Northwest Laboratory

Study Methodology and Safety Considerations

\section{Fault Tree Consultant}

P. A. Crosett $i$ United Nuclear Industries

\section{Risk and Public Response Task Force}

S. S. Epstein, M.D. Case Western University

J. McCarrol1, M.D. Los Angeles Medical Services Division

S. M. Nealey Battelle, Human Affairs Research Center

L. H. Rappoport Kansas State University

L. A. Sagan, M.D. Palo Alto Clinic

C. Starr Electric Power Research Institute

P. Slovic Oregon Research Institute

N. E. Rasmussen Massachusetts Institute of Technology

Geologic Disposal Concepts

\section{Reviewers}

W. S. Twenhofe 1

U.S. Geological Survey, Denver

R. K. Blankennagel

U.S. Geological Survey, Denver

G. D. deBuchannane

U.S. Geological Survey, Washington, DC

A. L. Boch

Oak Ridge National Laboratory

T. F. Lomenick

Oak Ridge National Laboratory 
W. C. McClain

Oak Ridge National Laboratory

J. 0. Blomeke

Oak Ridge National Laboratory

\section{Consultants}

R. F. Walters, Walters Drillina Co.

P. F. Kerr

H. A. Coombs University of Washington

J. Gilluly

R. L. Loofbourow

G. C. Kennedy University of California Los Angeles

Ice Sheet Disposal Concepts

Consultant and Reviewer

C. B. B. Bull Ohio State University

Reviewers

J. H. Zumberge University of Nebraska

M. F. Meier U.S. Geological Survey

E.J. Zeller University of Kansas

Seabed Disposal Concepts

Consultant and Reviewer

M. N. A. Peterson Scripps Institution of Oceanography

Reviewers and Technical Editorial Assistance

W. P. Bishop Sandia Laboratories

C. D. Hollister Woods Hole Oceanographic Institute

\section{Reviewers}

D. A. McManus University of Washington

J. S. Creager University of Washington

A. J. Coyle Battelle Columbus
Transmutation Concepts

\section{Reviewers}

A. S. Kubo

U.S. Military Academy

West Point

B. I. Spinrad

Oregon State University

H. W. Lefevre University of Oregon

C. J. Poncelet Carnegie-Mel1on Institute

J. L. Crandall

E. I. duPont de Nemours and Co.

R. E. Hellens Combustion Engineering, Inc.

D. G. Foster, Jr. University of California

Waste Partitioning

Amicon Corp., Cambridge, MA

C. E. Armantrout U.S. Bureau of Mines

L. E. Bruns Atlantic Richfield Hanford Co.

W. W. Schulz Atlantic Richfield Hanford Co.

C. R. Cooley Hanford Engineering Development Laboratory

R. E. Lerch Hanford Engineering Development Laboratory

G. L. Richardson Hanford Engineering Development Laboratory

R. E. Leuze Oak Ridge National Laboratory

D. F. Peppard Argonne National Laboratory

H. C. Rathvon Exxon Nuclear

T. H. Siddall Louisiana State University

R. E. Sparks

G. W. Watt Washington University

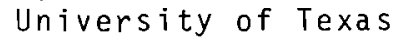

\section{Report Editor}

J. A. Powe 11 


\section{CONTENTS - TOTAL REPORT}

Abbreviated contents of the total 4-volume report are 1 isted here. Detailed contents of each of the nine sections are listed at the front of each section.

\section{VOLUME 1}

STUDY CONTRIBUTORS - TOTAL REPORT FOREWORD.

ACKNOWLEDGMENTS - TOTAL REPORT

CONTENTS - TOTAL REPORT .

1.0 SUMMAR

1.1 INTRODUCTION

1.2 HIGH-LEVEL RADIOACTIVE WASTE MANAGEMENT

1.3 HIGH-LEVEL RADIOACTIVE WASTE

1.4 STUDY METHODOLOGY .

1.5 SAFETY CONSIDERATIONS .

1.6 DISPOSAL CONCEPTS - DEESCRIPTION AND SYSTEMS

1.7 TECHNICAL FEASIBILITY

1.8 RESEARCH, DEVELOPMENT, AND TIMING.

1.9 WASTE MANAGEMENT COSTS.

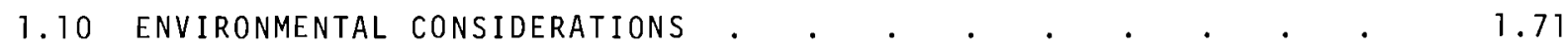

1.11 POLICY CONFLICTS . . . . . . . . . . . . . . . . . . . . . . . . . . . . . . . . .

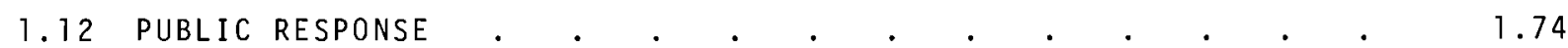

1.13 SELECTED BIBLIOGRAPHY . . . . . . . . . . . . . . . . . . . . . 1.76

2.0 BACKGROUND AND DATA BASE . . . . . . . . . . . . . . . . . 2.1

2.1 WASTE MANAGEMENT OPTIONS . . . . . . . . . . . . . . . . . . . . 2.1

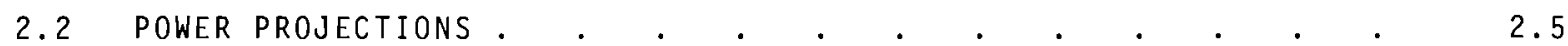

2.3 REACTOR PLANTS. . . . . . . . . . . . . . . . . . . . . . 2.7

2.4 FUEL REPROCESSING AND HIGH-LEVEL WASTE. . . . . . . . . . . . . 2.9

2.5 HIGH-LEVEL WASTE CHARACTERISTICS . . . . . . . . . . . . 2.13

REFERENCES . . . . . . . . . . . . . . . . . . . . . . . . . . .

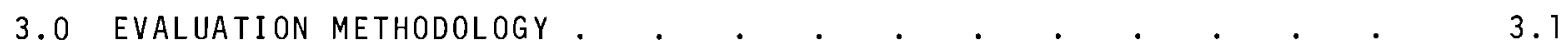

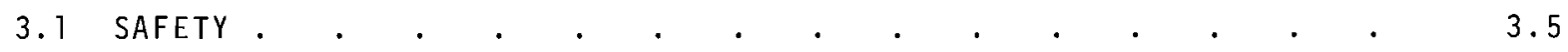

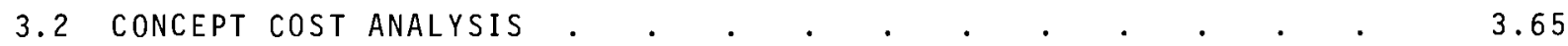

3.3 POLICY CONSIDERATIONS

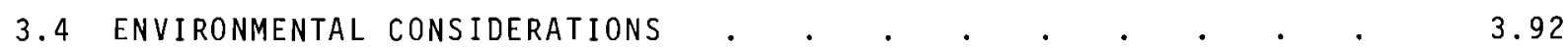

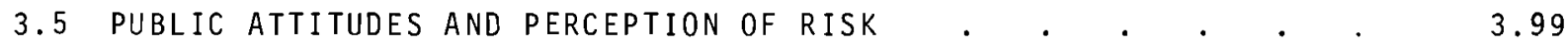
REFERENCES . . . . . . . . . . . . . . . . . . . . 3.112 


\section{APPENDICES FOR VOLUME 1}

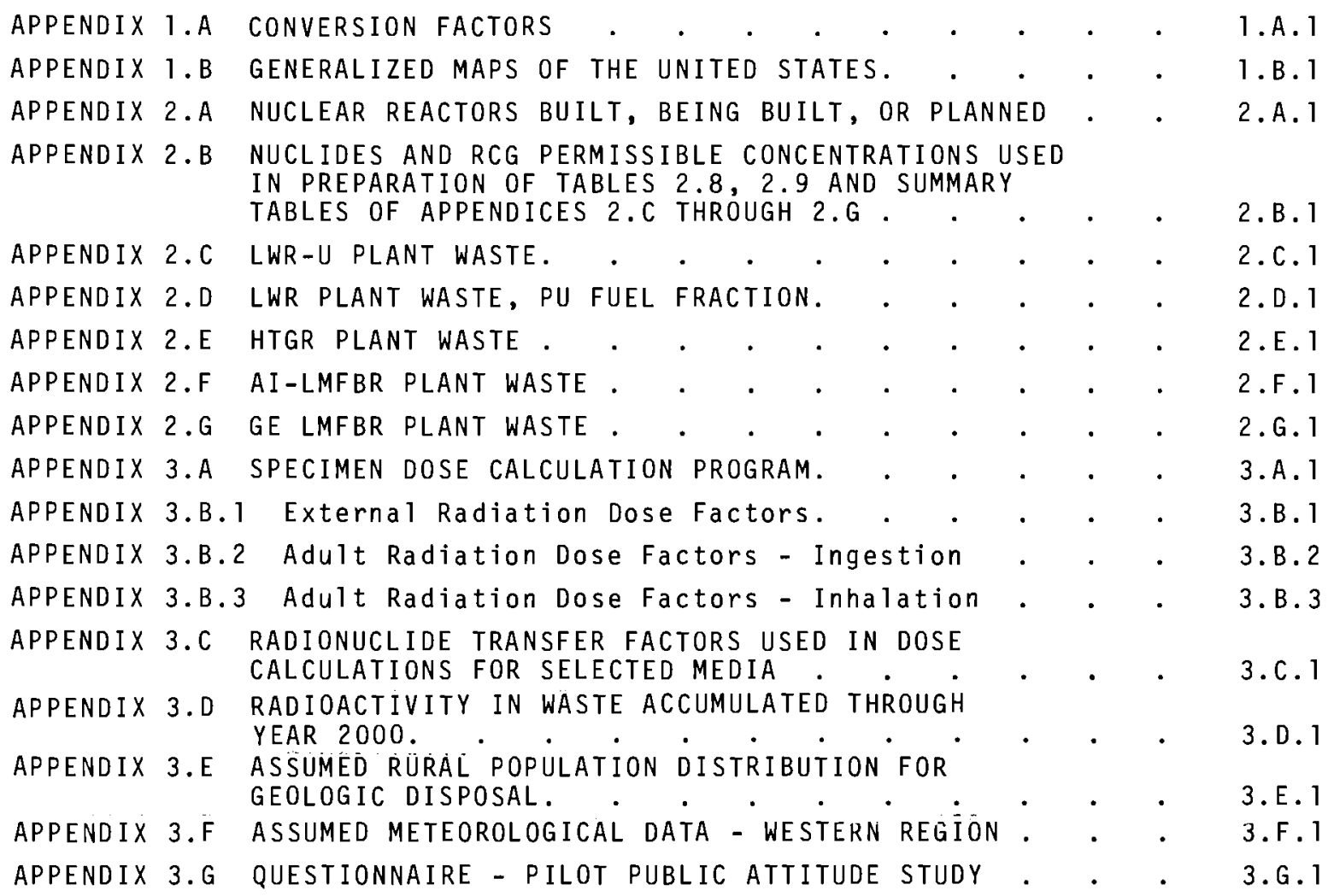

VOLUME 2

STUDY CONTRIBUTORS - TOTAL REPORT

FOREWORD

ACKNOWLEDGMENTS.

CONTENTS - TOTAL REPORT.

4.0 GEOLOGIC DISPOSAL .

4.1 DESCRIPTION OF GEOLOGIC DISPOSAL CONCEPTS . $. \quad . \quad$. $\quad . \quad$. $\quad . \quad 4.104$

4.2 SYSTEM REQUIREMENTS FOR THE CONCEPTS . . . . . . . . . . . 4.138

4.3 GEOLOGIC CONSIDERATIONS FOR SPECIFIC CONCEPTS . $\quad . \quad$. $\quad . \quad . \quad 4.148$

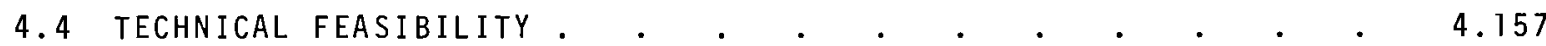

4.5 SAFETY. . . . . . . . . . . . . . . . . . . . . . . . . . . . . . . . . . . . . .

4.6 RESEARCH AND DEVELOPMENT NEEDS. . . . . . . . . . . . . . . . . 4.165

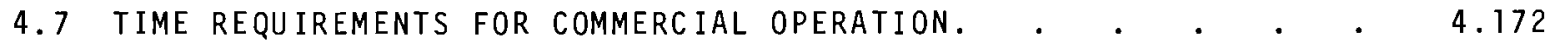

4.8 CAPITAL AND OPERATING COSTS . . . . . . . . . . . . . . . 4.172

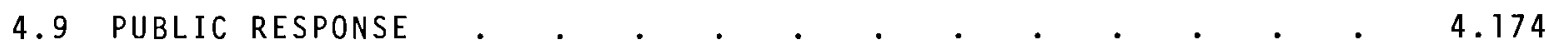

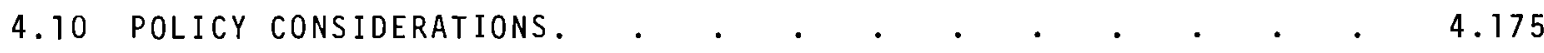

4.11 ENVIRONMENTAL IMPACT . . . . . . . . . . . . . . . . . . . 4.177 


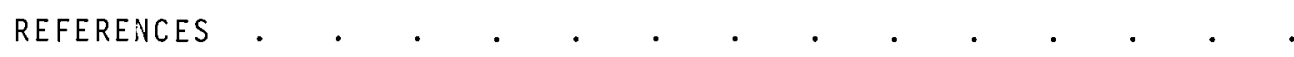

APPENDIX 4.A GLOSSARY OF GEOHYDROLOGIC TERMS . . . . . . .

APPENDIX 4.B MAJOR STRATIGRAPHIC AND TIME DIVISIONS • • •

4. B. 1

APPENDIX 4.C CHEMICAL COMPOSITIONS (IN PERCENT) AND PHYSICAL AND

4.C. 1

APPENDIX 4.D MO HYDROLOGIC PROPERTIES OF PRINCIPAL ROCK TYPES . .

APPENDIX 4.E PROMINENT EARTHQUAKES IN THE UNITED STATES

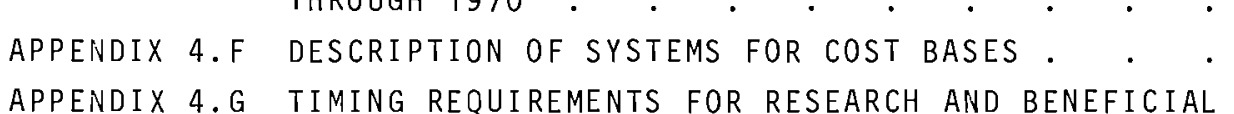

4. E. 1

4.F. 1 OCCUPANCY OF A COMMERCIAL REPOSITORY $\cdot$.

4. G. 1

VOLUME 3

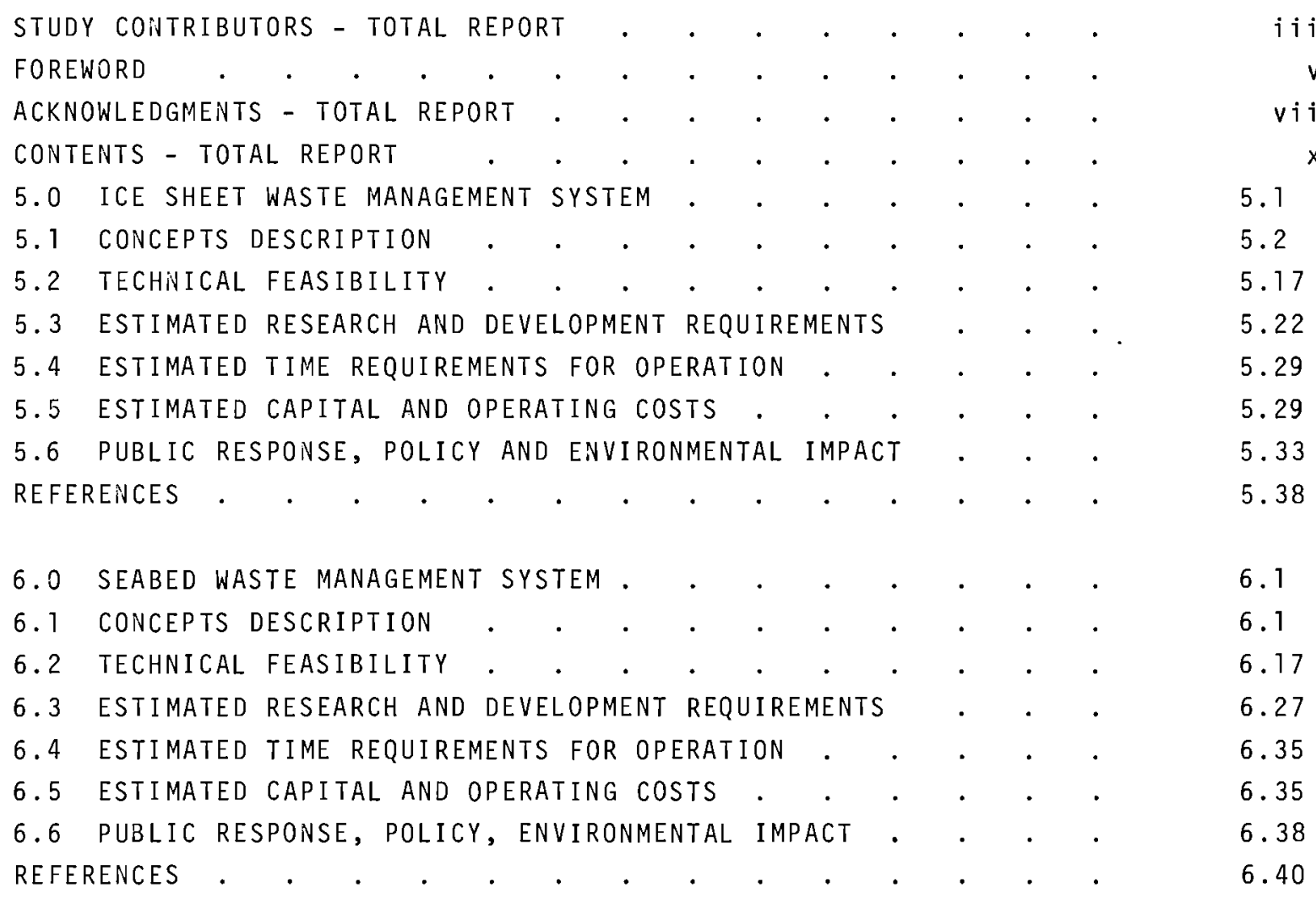

APPENDICES FOR VOLUME 3

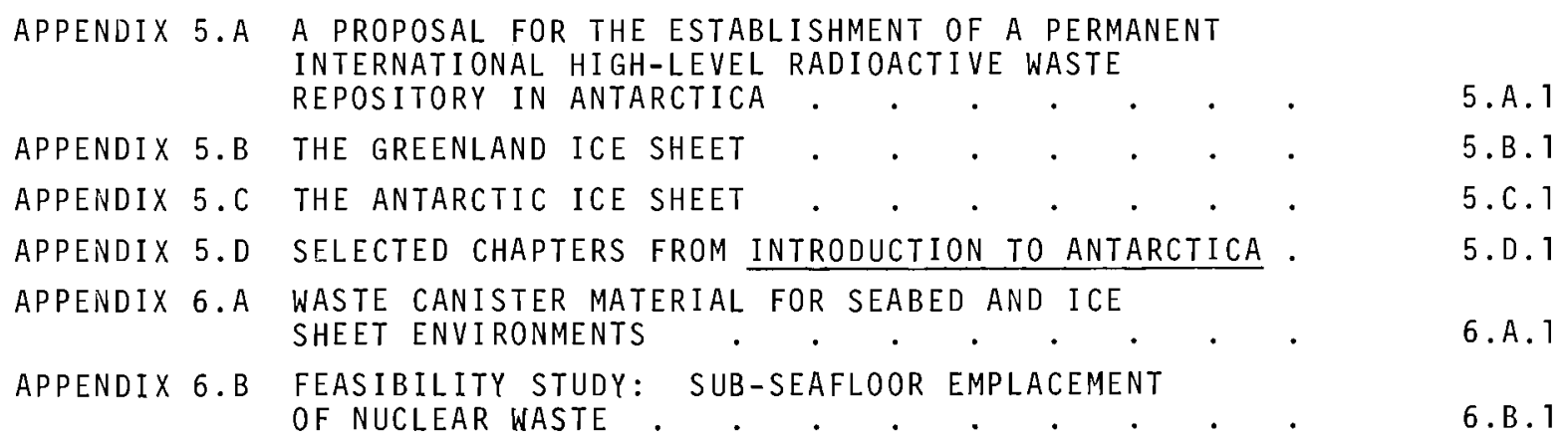


VOLUME 4

STUDY CONTRIBUTORS - TOTAL REPORT

FOREWORD.

ACKNOWLEDGMENTS - TOTAL REPORT

CONTENTS - TOTAL REPORT.

7.0 POTENTIAL FOR WASTE PARTITIONING

7.1 BENEFITS TO BE GAINED

7.2 PARTITIONIING PROCESSES

7.3 ANALYTICAL REQUIREMENTS.

7.4 PARTITIONING COSTS

7.5 RESEARCH AND DEVELOPMENT REQUIREMENTS REFERENCES

8.0 EXTRATERRESTRIAL DISPOSAL

8.1 EXTRATERRESTRIAL WASTE MANAGEMENT SYSTEM

8.2 TECHNICAL FEASIBILITY

8. 3 RESEARCH AND DEVELOPMENT REQUIREMENTS

8.4 TIME REQUIREMENTS FOR COMMERCIAL OPERATION

8.5 CAPITAL AIND OPERATING COSTS

8. 6 PUBLIC RESPONSE, POLICY AND ENVIRONMENTAL

REFERENCES

9.0 TRANSMUTATION PROCESSING/ELIMINATION

9.1 TRANSMUTATION WASTE MANAGEMENT SYSTEMS

9.2 TECHNICAL FEASIBILITY

9.3 ESTIMATED RESEARCH AND DEVELOPMENT REQUIIREMENTS

9.4 ESTIMATED TIME FOR REQUIREMENTS FOR OPERATION

9.5 CAPITAL AND OPERATING COSTS

9.6 PUBLIC RESPONSE

9.7 POLICY CONSIDERATIONS

9.8 ENVIRONMENTAL CONSIDERATIONS

9.9 SAFETY ASPECTS OF ACTINIDE RECYCLE IN LWRS

REFERENCES

\section{APPENDICES FOR VOLUME 4}

APPENDIX 8.A NASA EXECUTIVE SUMMARY - FEASIBILITY OF SPACE DISPOSAL OF RADIOACTIVE NUCLEAR WASTE . $. \quad . \quad . \quad . \quad 8 . A .1$

APPENDIX 8.B STUDY OF EXTRATERRESTRIAL DISPOSAL OF RADIOACTIVE WASTES PART II

8. B. 1

APPENDIX 8.C AN EVALUATION OF SOME SPECIAL TECHNIQUES

FOR NUCLEAR WASTE DISPOSAL IN SPACE . . . . . . . 8.C. 1

APPENDIX 8.D FEASIBILITY OF USING AN ORBITING ACCELERATOR

TO EJECT RADIOACTIVE WASTE PRODUCTS INTO SPACE. . . . 8.D.1 
APPENDIX 8. E TERRESTRIAL AND STELLAR CONTAMINATION FROM SPACE DISPOSAL OF NUCLEAR WASTES

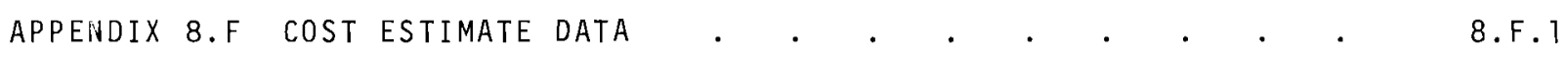

APPENDIX 9.A TRANSMUTATION BY ACCELERATORS . . . . . . . . . . . . 9.A.1

APPENDIX 9.B TRANSMUTATION BY FISSION AND THERMONUCLEAR

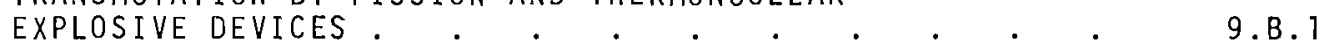

APPENDIX 9.C TRANSMUTATION BY FISSION REACTORS . . . . . . . . . 9.C.1

APPENDIX 9.D TRANSMUTATION BY FUSION (CTR) REACTORS. . . . . . . 9.D.1

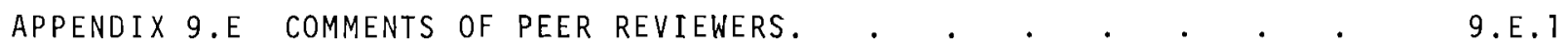


SECTION 4: GEOLOGIC DISPOSAL

Section 4 Contributors

M. R. Kreiter, Study Leader

K. J. Schneider, Study Leader

L. L. Ames

J. N. Hartley

G. Jansen

J. D. Kaser

J. R. Sheff

D. H. Stewart

D. D. Tillson

R. W. Wallace W. K. Winegardner

G. A. Dinwiddie

E. B. Ekren

E. N. Hinrichs

J. W. Mytton

USGS-Denver

L. J. Schroder

W. Thordarson

J. E. Weir, Jr.,

S H. Woodcock

Fenix and Scisson Drilling Co. 


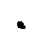


LIST OF FIGURES

LIST OF TABLES

4.0 GEOLOGIC UISPOSAL

4.0.1 Background on Geologic Disposal Concepts . . . . . . . . 4.1

4.0.2 General Systems Requirements for Geologic Concepts. . . 4.2

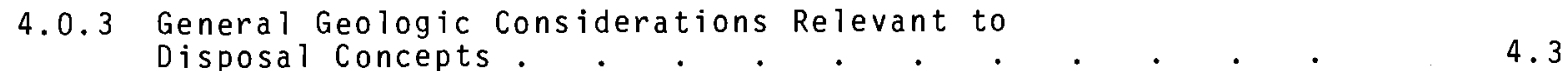

4.0.3.1 Basic Description of Earth System . . . . . . . . . 4.5

4.0.3.2 Lithologic Considerations . . . . . . . . . . . . . . . . . . . . 4.9

4.0.3.2.1 Sedimentary Rocks . . . . . . . . . . . . . . . . . . 4.9

4.0 .3 .2 .2 Igneous Rocks. . . . . . . . . . . . . . . . . . . . . . . 43

4.0.3.2.3 Metamorphic Rocks. . . . . . . . . . . . . . . . . 4.15

4.0.3.3 Hydrologic Considerations . . . . . . . . . . . . . . . . . 47

4.0 .3 .3 .1 Flow Systems. . . . . . . . . . . . . . . . . . . . 47

4.0.3.3.2 Stratification and Faulting . . . . . . . . 4.20

4.0.3.3.3 Permeability . . . . . . . . . . . . . . . . 4.20

4.0.3.3.4 Liquid-Versus Solid-Waste Disposal. . . . . . . 4.20

4.0.3.3.5 Groundwater Transport . . . . . . . . . . . . . . 4.23

4.0.3.3.6 Sedimentary Basins. . . . . . . . . . . . . . . . . . . . . 4.26

4.0.3.3.7 Igneous and Metamorphic Systems . . . . . . . 4.30

4.0.3.4 Geochemical Considerations . . . . . . . . . . . . . . 433

4.0.3.4.1 Ion-Exchange Reactions. . . . . . . . . . . . . 4.33

4.0.3.4.2 Rock-Waste Interactions in the Presence of Water. . 4.35

4.0.3.4.3 Molten Rock-Waste Interactions. . . . . . . 4.40

4.0.3.5 Physiographic Considerations . . . . . . . . . . . 4.44

4.0.3.5.1 Erosion and Denudation Effects . . . . . . . . 4.45

4.0.3.6 Seismologic Considerations . . . . . . . . . . . . . . . . . 4.48

4.0.3.7 Climatic Changes . . . . . . . . . . . . . . . . . . . . . 4.54

4.0.3.7.1 Effects of Glacial Climate . . . . . . . . . . . . . . 4.56

4.0.3.7.2 Effects of Sea-Level Change . . . . . . . . . . . . 4.58

4.0.3.7.3 Effects of Pluvial Climate . . . . . . . . . . . 4.59

4.0.3.8 Resource Potential . . . . . . . . . . . . . . . . 4.59

$\begin{array}{lll}\text { 4.0.3.9 Resume of Preferred Geohydrologic } & & \\ \text { and Related Characteristics } & 4.61\end{array}$

4.0.3.9.1 Mined Cavity Concepts . . . . . . . . . . . . . 4.61

4.0.3.9.2 Mined Cavity with Separate Manmade Structures . . 4.64

4.0.3.9.3 Exploded Cavity Concepts . . . . . . . . . . 4.64

4.0.3.9.4 Matrix Drilled Holes (300 to 6000 meters). . . . 4.66

4.0.3.9.5 Deep Drilled Hole (9000 to 16,000 meters). . . . 4.69

4.0.4 Radionuclide Migration in Soils . . . . . . . . . . . . . 4.72

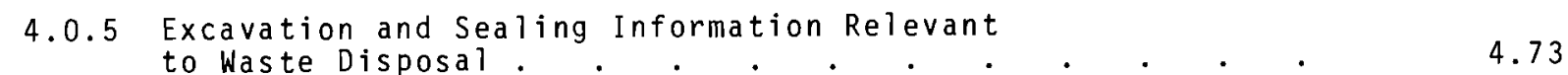

4.0.5.1 Hole Forming . . . . . . . . . . . . . . . . . 4.74 
4.0.5.1.1 Conventional Dritiing.

4.0.5.1.2 Advanced Hole Forming Technology . . . . . . . . . . . 4.79

4.0 .5 .2 Cavity Forming . . . . . . . . . . . . . . . . . . . . . 4.86

4.0.5.3 Borehole Sealing . . . . . . . . . . . . . . . . . . . 4.88

4.0.6 Heat Removal Relative to Waste Disposal . . . . . . 4.93

4.0.6.1 The Nature of the Heat Transfer Problem. . . . . . 4.94

4.0.6.2 Arrays of Heat Sources . . . . . . . . . . . . . . . . . . . 46

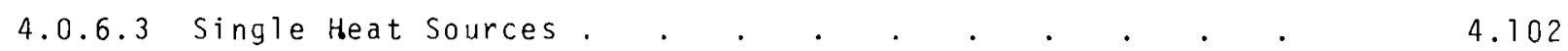

4.1 DESCRIPTION OF GEOLOGIC DISPOSAL CONCEPTS . . . . . . . 4.104

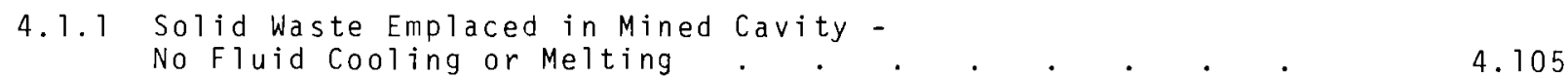

4.1.2 Solid Waste Emplaced in Mined Cavities - Interim
Liquid Cooling and Conversion to Rock-Waste Matrix. . . 4.107

4.1.3 Solid Waste Emplaced in Manmade Structures in Geologic Formations--Interim Air Cooling . . . . . . . 4.113

4.1 .4 Solid Waste Emplaced in Manmade Structures in
Geologic Formations--Interim Water Cooling. . . . . . . 4.16

4.1.5 Liquid Waste Emplaced in a Mined Cavity - In-Place

4.1.6 Liquid Waste Emplaced in Exploded Cavities In-Place Drying and Conversion to Rock-Waste Matrix . . 4.121

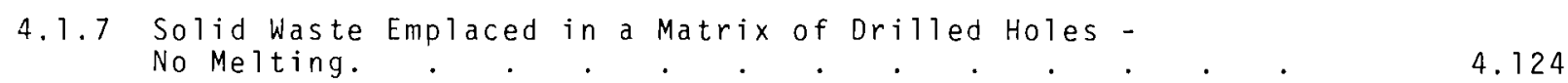

4.1.8 Solid Waste Emplaced in a Deep Hole - In-Place
Conversion to a Rock-Waste Matrix. . . . . . . . . . 4.127

4.1.9 Liquid Waste Emplaced in a Deep Hole - In-Place . . . . .
Drying and Conversion to Rock-Waste Matrix. . 429

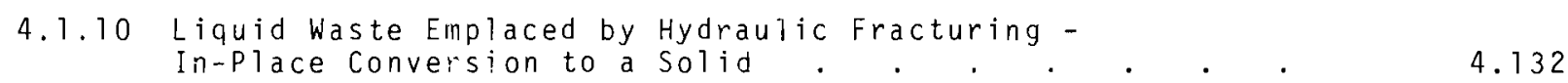

4.2 SYSTEM REQUIREMENTS FOR THE CONCEPTS . . . . . . . . . . 4.138

4.2.1 Prior Waste Treatment and Handiing . . . . . . . . . 4.139

4.2 .2 Site Preparation . . . . . . . . . . . . . . . . . . . . . . 440

4.2.3 Transportation to the Site . . . . . . . . . . . . . 442

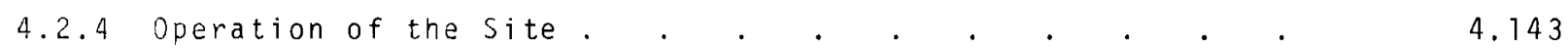

4.2.5 Final Sealing from Man's Environment . . . . . . . . . 4.148

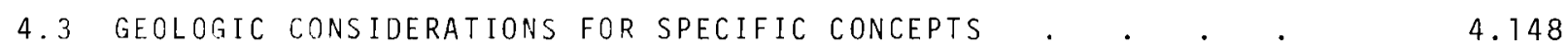

4.3.1 Thermal Properties of the Host Rock . . . . . . . . 4.150

4.3.2 Engineering Properties of the Host Rock . . . . . . 4.150

4.3 .3 Water Content of the Host Rock . . . . . . . . . 4.153

4.3.4 Mineral Resources Potential . . . . . . . . . 4.154

4.3.5 Geothermal Resource Potential . . . . . . . . . . . . 454

4.3 .6 Geographic Characteristics . . . . . . . . . . . . . . 4.154

4.3 .7 Seismicity and Faulting . . . . . . . . . . . . . . . . . 454

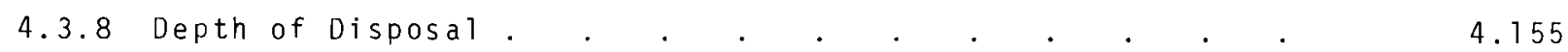

4.3.9 Dimensions of Host Rock . . . . . . . . . . . . . . . . . . . 457

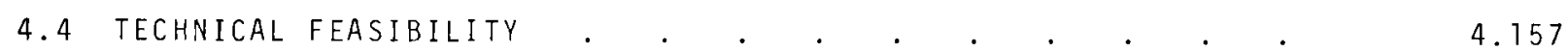

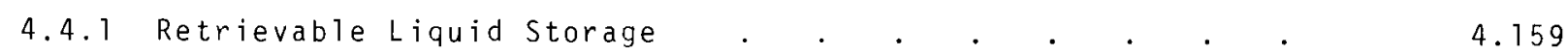




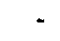

4

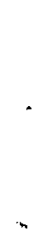

$+$ 


\section{LIST OF FIGURES}

4.1 System Requirements for High-Level Radioactive Waste Management in Geologic Locations . . . . .

4.2 Cross Sections of the Earth and Parts of the Earth's Crust and Mantle

4.3 Summary Map of Slip Vectors in the Pacific Area.

4.4 Idealized Gravity Flow Through Basin . . . . . . . . . . 4.18

4.5 Groundwater Areas . . . . . . . . . . . . . . . . . . 49

4.6 Locations of Sedimentary Basins. . . . . . . . . . . . . . 4.24

4.7 Geologic Section Through Delaware and Midland Basins,

4.8 Thermal Springs in the United States . . . . . . . . . . 4.29

4.9 Rock Salt Deposits in the United States, Parts of
Which Are Potentially Suitable for Waste Disposal . . . . $\quad 4.31$

4.10 Principal Areas of Intrusive Igneous and Metamorphic Rocks and Contours Showing Thickness of Sedimentary Rocks in the United States.. .0 .0 .4 .32$

4.11 Cross Section Through Pine Mountain and Warm Springs, Georgia, Showing Geologic Structure and (by Arrows) Probable Course of the Water That Enters Hollis Quartzite as Rain on Pine Mountain and Is Discharged at warm Springs

4.12 Ranges of Distribution Coefficients for Various . . . . 4.36

4.13 Distribution of Mineral Groups in a Temperature -
Pressure Diagram of the Earth's Upper Crust . . . . $\quad 4.37$

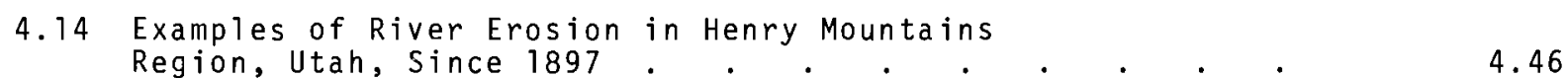

4.15 Damaging Earthquakes in the United States

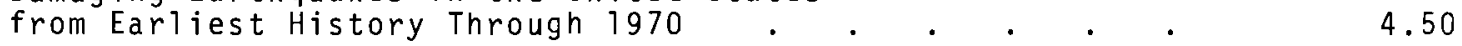

4.16 Principal Faults Located in the United States. . . . . 4.53

4.17 Seismic Risk Map of the United States. . . . . . . . 4.55

4.18 Maximum Extent of Glaciation in the United States. . . 4.57

4.19 Quaternary Sea-Level oscillations . . . . . . . . . 4 4.58

4.20 Areas of the United States That Would be
Inundated by 60 - and 150 Meters Sea-Level Rise . . . . $\quad 4.60$

4.21 Total Porosities of Sedimentary
Rocks Versus Depth.

4.22 Transient Temperature Around an Exponentially
Decaying Infinite Extent Plane Source. . . . . . . . . . . . 46

4.23 Transient Temperatures in an Exponentially Decaying
Plane Source - Effect of Thermal Conductivity . . . 4.97

4.24 Effect of Burial Depth on Maximum Temperatures in
an Exponentially Decaying Plane Source. . . . . . . . . 48

4.25 Effect of Disc Size on Maximum Temperature of
an Exponentially Decaying Heat Source . . . . . . . . . . . . 49 4.26 Effect of Spacing and Canister Radius on Temperature
in Arrays of Buried Waste Canisters Containing . . . . . . . . . 4.100 
4.27 Effect of Power Density and Canister Radius on

Temperature in Arrays of Buried Waste Canisters

Containing Exponentially Decaying Heat Source

4.28 Effect of Rock Thermal Conductivity and Power

Density on Temperature in Arrays of Buried Waste

Canisters Containing Exponentially Decaying Heat Sources

4.29 The Effect of Waste Age on the Maximum Wall

Temperature of Single Buried Canisters.

4.30 Size of Molten Pool as a Function of Heat

4.31 Solid Waste Emplacement in a Mined Cavity - No

Fluid Cooling or Melting

4.32 Overall Facility Needs - Solidified Waste in

Mined Cavity

4.33 Solid Waste Emplacement in a Mined Cavity - Interim

Liquid Cooling and Waste-Rock Melting . . . . . .

4.34 Flow Diagram Showing Emplacement of Solid Waste in a Mined Cavity - Interim Liquid Cooling and

4.35 Well-Head Concept for Solid Waste Emplacement in a Mined Cavity - Interim Liquid Cooling and WasteRock Melting

4.36 Solid Waste Emplacement in a Mined Tunnel - Interim Natural Convection Air Cooling, No Melting.

4.37 Solid Waste Emplacement in Manmade Structure with Interim Boiling Water Cooling, No Melting.

4.38 Liquid Waste Emplacement in a Mined Cavity - InPlace Drying and Conversion to Rock-Waste Matrix

4.39 Time Scale for Steps in Liquid Waste Emplacement in a Mined Cavity........

4.40 Flow Diagram for Liquid Waste Emplaced in Mined Cavities - In-Place Drying and Conversion to Rock-Waste Matrix

4.4l Facility Requirements at the Well Head - Liquid Waste Emplaced in Mined Cavities

4.42 Liquid Waste Emplacement in an Exploded Cavity - InPlace Drying and Conversion to Rock-Waste Matrix

4.43 Pipe and Bottom Hole Configuration for Exploded Cavity Concept with Liquid Waste

4.44 Solid Waste Emplacement in a Matrix of Drilled Holes - No Melting.

4.45 Conceptual Facilities for Solid Waste Emplaced in

4.46 Solid Waste Emplacement in a Deep Hole with InPlace Conversion to a Rock-Waste Matrix 
4.47 Flow Diagram for Solid Waste Emplacement

in a Deep Hole . . . . . . . . . . . . . . .

4.48 Facility Requirements at the Well Head - Solid

Waste Emplaced in Deep Holes with Melting . . . . . . $\quad 4.130$

4.49 Liquid Waste Emplacement in a Deep Hole - In-

Place Drying and Conversion to Rock-Waste Matrix... .

4.50 Liquid Waste Emplacement by Hydraulic Fracturing -

In-Place Conversion to a Solid. . . . . . . . . . .

4.134

4.51 Waste Injection Well for Hydraulic Fracturing

(Source: Reference 135) . . . . . . . . . . . . . . 435

4.52 Flow Diagram of Surface System for Hydraulic

Fracturing--Grout Mix-Waste Disposal

(Source: Reference 131) . . . . . . . . . . . . . . 4.136

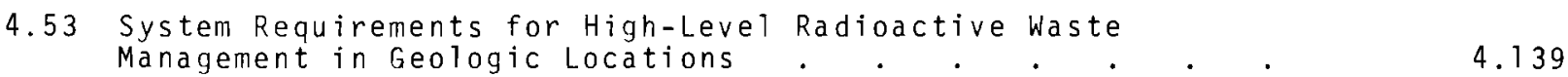

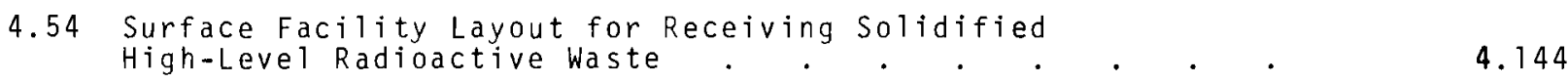




\section{LIST OF TABLES}

4.1 Principal Sedimentary Rocks . . . . . . . . . . . . . 4.10

4.2 General Classification and Principal Mineral

Assemblages of Igneous Rocks . . . . . . . . . . . . . . . . 4.14

4.3 Principal Metamorphic Rocks . . . . . . . . . . . . . 4.16

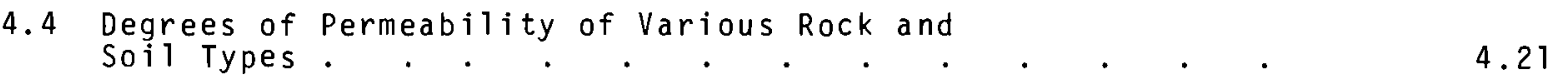

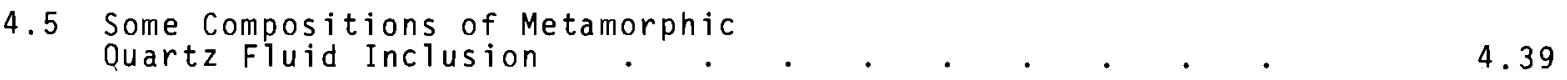

4.6 Composition of Melt Number 72-4 Minus the FP

4.7 Range of Minor Constituents of Average Composition

Rocks in Parts Per Milion ( $R E=$ rare earths,

PtGr = platinum group) . . . . . . . . . . . 4.41

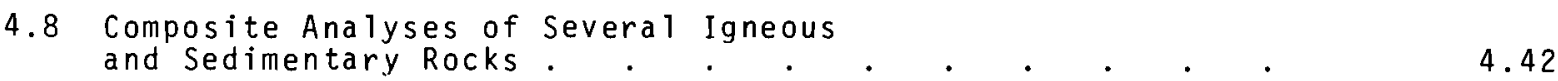

4.9 Synthetic Rocks Produced by Mixing Equal

Weights of Melt No. 72-4 and Several Natural

Rocks and Closest Natural Equivalents.

4.43

4.10 Mineral Phases Present in the Natural Equivalents
of the Synthetic Waste-Rock Mixtures of Table $4.9 \quad$. . $\quad 4.44$

4.11 Strain Release Index for Four Areas

of the United States. . . . . . . . . . . . . . 4.51

4.12 Recurrence of Earthquakes in Conterminous
United States per 100 Years for Modified Mercal1i Intensities V to VIII . . . . . . . . . 4.51

4.13 Recurrence of Earthquakes in Conterminous
United States per 100 Years per $100,000 \mathrm{~km}^{2}$, Intensities V to VIII . . . . . . . . 4.52

4.14 Large-Diameter Drill Hole Depths . . . . . . . . . . 4.77

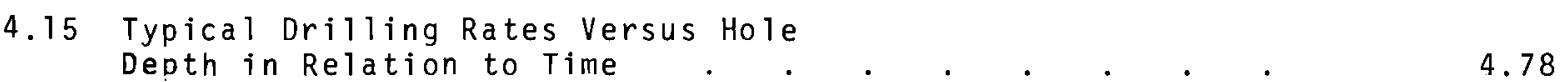

4.16 Classification of Novel Drills . . . . . . . . . . . . $\quad 4.80$

4.17 Water Penetration Through Cement and Clay-Sand
Plugs at Pressure of 6.8 Atmospheres . . . . . . . . . $\quad 4.90$

4.18 Portland Cement Characteristics . . . . . . . . . . 4.91

4.19 Specialty Hole Sealant Characteristics . . . . . . . 4.92

4.20 Properties Used in Molten Pool Calculations . . . . . 4.104

4.21 Characteristics of Geologic Disposal Concepts . . . 4.105

4.22 Summary of the 0verall Characteristics; Solid Waste Emplaced in Mined Cavity - No fluid Cooling

4.23 Summary of the overall Characteristics, Solid Waste Emplaced in Mined Cavity; Initial Water Cooling; Melting. 4.112

4.24 Summary of the Overall Characteristics; Solid Waste Emplaced in Manmade Structure in Mined Cavity; Initial Air Cooling; No Melting

4.25 Summary of the Overall Characteristics; Solid Waste Emplaced in Manmade Structure in Mined Cavity; Initial Water Cooling; No Melting 
4.26 Summary of the Overall Characteristics; Liquid Waste Emplaced in Mined Cavity; Initial Reflux Cooling; Melting

4.27 Summary of the 0verall Characteristics; Liquid Waste Emplaced in Exploded Cavity; Initial Reflux Cooling; Melting

4.28 Summary of the Overall Characteristics; Solid Waste Emplaced in Matrix of Drilled Holes; No Fluid

4.29 Summary of the Overall Characteristics; Solid Waste Emplaced in Deep Holes; No Fluid Cooling; Melting or Nonmelting

4.30 Summary of the Overall Characteristics; Liquid Waste Emplaced in Deep Holes; Initial Reflux Cooling; Melting

4.31 High-Level Waste Disposal by Hydraulic Fracturing Waste Injection Data. . . . . . . . . . . . . . . . . 437

4.32 Summary of the Overall Characteristics; Liquid Waste Emplaced by Hydrofracture; In-Place Curing: . . . . . 4.138

4.33 Typical Thermal Conductivity of Potential Host Geologic Rocks . . . . . . . . . . . . . . . . . 4.150

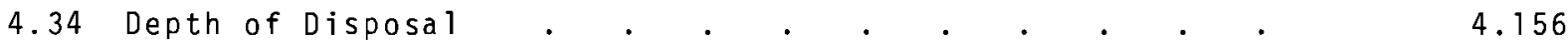

4.35 Summary of Technical Feasibility for Alternative Geologic Waste Management Systems . . . . . . . . .

4.36 Estimated Energy Requirements for Excavation . . . . . 4.162

4.37 Basic Geologic Disposal Failure Events Identified by Fault Tree Analysis . . . . . . . . . . . . . . . 4.166

4.38 Estimated Research and Development Needs and Timing to Routine Operations for Geologic Disposal Concepts

4.39 Capital and Operating Costs for Geologic Disposal Concepts 


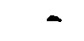

$\therefore$ 


\subsection{GEOLOGIC DISPOSAL}

Disposal of radioactive waste in geologic formations has the potential of isolating the waste from man's environment for extended time periods (millions of years). Geologic environments exist which have been physically and chemically stable for millions of years, are isolated from man's environment, and have the potential to provide effective barriers between the waste and man's environment for the time periods required.

Disposal in bedded salt, which is under study for the U.S. Atomic Energy Commission at the Oak Ridge National Laboratory, is not specifically covered in this study but it is included in the overall study matrix. The concepts presented in this report are typically suggested by others, sometimes with modifications which are outgrowths of the study itself.

The geologic disposal concepts were studied on a generic and systematic basis, with studies aimed at inherent characteristics. No attempts were made to define the concepts in detail or to optimize any of the concepts.

Section 4.0 discusses general considerations relevant to more than one concept. Sections 4.1 through 4.11 discuss the details of individual disposal concepts including a description of the concepts; waste management systems requirements beginning with discharge of highlevel liquid waste from a plant reprocessing "spent" nuclear fuel and ending with final waste emplacement in a geologic formation; concept related geologic considerations; technical feasibility; concept safety; research and development needs, including estimated costs; time required to commission, and estimated capital and operating costs associated with a facility for disposal of commercially generated radioactive waste; and policy, environmental, and public response considerations.

\subsubsection{Background on Geologic Disposal Concepts}

The basic requirement for any geologic environment to be suitable for disposal of radioactive waste is the capability to safely isolate the emplaced radioactive material until decay has reduced the radioactivity to nonhazardous levels. The geologic environment should a) be adequately far removed from man's environment, b) not permit waste transport readily, c) remain relatively stable over geologic time periods, and d) adequately contain a highly immobile waste form.

A geologic formation can be penetrated and altered in several ways to provide a repository for waste emplacement purposes. This study considers the use of drilling, mining (mechanical and dissolution), exploded cavity formation and hydraulic fracturing. All of these methods become more difficult with increasing depth. At depths up to nearly 3 kilometers any of the methods may be used. Drilling has the potential of going to great depths; the present record is around $9 \mathrm{kilom-}$ eters (about 5.5 miles). 
The general methods considered in this study for placement and disposal of radioactive waste in geologic formations include:

- Placing solidified waste directly in a geologic formation

- Placing solidified waste in manmade containment barriers within a geologic formation

- Placing solidified waste in a geologic formation in a configuration to allow the waste to melt and form a rock-waste matrix

- Converting 1 iquid waste in-place within a geologic formation to form a solid waste or a rockwaste matrix.

Each of these basic concepts has a number of variations, depending upon the specific method of accomplishing this placement of waste. Furthermore, each of the variations will have specific requirements with respect to the host geologic environment. A total of ten concept variations was considered in this study, with at least two in each of the basic methods listed above.

\subsubsection{General Systems Requirements for Geologic Concepts}

The general management system flow diagram for potential geologic waste disposal concepts is shown in Figure 4.1. This figure shows the major possible steps required in managing waste using geologic disposal. The flow diagram starts with bulk high-level aqueous waste from the fuel reprocessing plant and carries it through final isolation and sealing from man's environment.

In general, geologic disposal options are not considered to require preconditioning or partitioning of the aqueous waste. Geologic disposal does not preclude the use of these steps, but if such steps are taken, they may be done for reasons not directly related to geologic disposal needs. It is assumed in this study that geologic disposal options will be aimed at manaing the total high-level waste, including the long-1ived radionuclides.

Most geologic disposal concepts will require similar waste management steps. The primary differences exist between the liquid and the solid waste emplacement concepts. For the solid waste emplacement concepts interim retrievable storage of the liquid waste may or may not be used; solidification of the waste must be done at the reprocessing plant; interim retrievable storage of solid waste is optional, but is considered to be likely; (a) the solid waste must be transported to the disposal site; following site preparation, the waste is emplaced in the disposal site; and the disposal site is sealed from man's environment and monitored for an indefinite time period.

For the liquid waste disposal concept interim retrievable storage of the liquid waste is generally not anticipated (with the probable

a. Interim retrievable storage of solidified waste is planned to be done at the proposed federal repository, the Retrievable Surface Storage Facility, for extended periods of time (until an ultimate disposal concept is ready for use). 


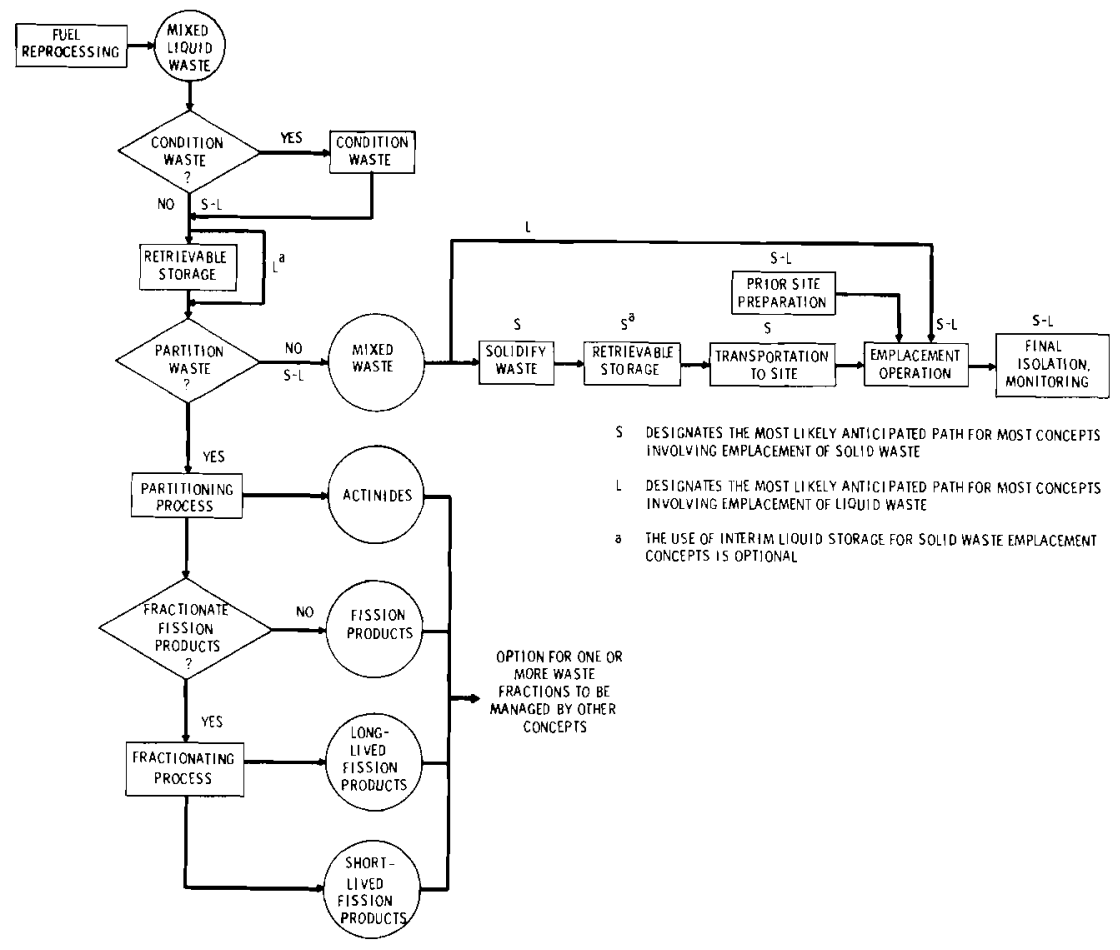

FIGURE 4.1 System Requirements for High-Leve?

Radioactive Waste Management in

Geologic Locations

exception of the hydrofracture concept); the bulk liquid waste would be emplaced directly into the geologic formation; and the disposal site is sealed from man's environment and monitored for an indefinite time period.

\subsubsection{General Geologic Considera- ations Relevant to Disposal Concepts}

This section presents the basis for and, to the extent possible, establishes general geohydrologic considerations that can be used in

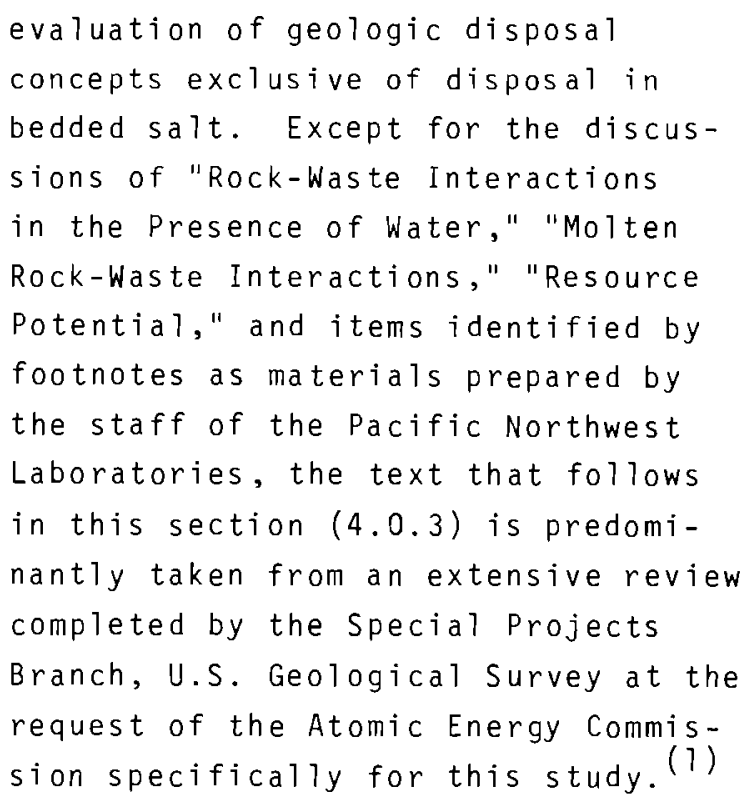


This review, "Geologic and Hydrologic Considerations for Various Concepts of High-Level Radioactive Waste Disposal in Conterminous United States," by E. B. Ekren, G. A. Dinwiddie, J. W. Mytton, W. Thordarson, J.E. Weir, Jr., E. N. Hinrichs and L. J. Schroder is available as an open file report in the Denver, Colorado office, U.S. Geological Survey. In addition to the general geohydrologic considerations summarized here, the USGS review briefly evaluates and identifies the geohydrologic environments in the conterminous United States that they consider as possibly suitable for the various geologic disposal concepts.

Because the following section on waste disposal has been oriented to an audience not necessarily familiar with geohydrologic terminology, a short glossary of terms has been included in Appendix 4.A. (1) A reference geologic time scale has been included as Appendix 4.B. (1)

of the various geohydrologic factors considered in evaluating potential sites for geologic disposal, the most important is hydrologic isolation to assure that the waste will be safely confined within an acceptable radius of the emplacement zone. To achieve this degree of hydrologic isolation the host rock for the waste should exhibit very low permeability and the site should be virtually free of geologic faults.

Areas considered generally unsuitable for waste disposal are those where seismic risk is high (seismic risk zone 3 ), where possible sea-level rise or changes in drainage patterns could inundate potential sites, where high topographic relief coincides with high fault densities and (or) unfavorable hydrologic conditions, where no suitable rock media are known to be present to reasonable depths, where a possible return of glacial or high rainfall climate will cause undesirable changes in the geology, where there is danger of exhumation by erosion, and where these strata either contain usable volumes of groundwater or have high oil and gas or other mineral potential

Potentially suitable media for the deep drill-hole method appear to be crystalline rocks, either intrusive igneous (e.g., granite) or metamorphic (e.g., quartzite) because of their potentially low permeabilities and high mechanical strengths. These same crystalline rocks, in addition to salt and suitable shale formations below about 2100 meters in depth, are candidates for matrix hole sites. salt (either in thick beds or stable domes), tuff, intrusive igneous and crystalline metamorphic rocks, and possibly shale appear to be suitable for mined chambers, cavities with separate manmade structures, and, exploded cavity methods. Salt appears to be suitable because of its very low permeability, high thermal conductivity, and natural plasticity. Tuff and shale appear suitable because of their very low permeabilities and high ion-exchange capacities. Sedimentary rocks other than shale and volcanic rocks, exclusive of 
tuff, are considered to be generally unsuitable for waste emplacement because of their potentially high permeabilities.

The physiography of a potentiat disposal site should have gentle relief to minimize any accelerated erosion or denudation that might occur because of natural climatic changes or changes brought about by the preparation for disposal operations. The most suitable geographic location for a disposal site is also one that is as far removed from major drainages, 1 akes, and oceans as possible and where the intrusion of man in a manner that will change the condition is minimal.

General areas and media that might be concluded to be potentialiy suitable for waste disposal will require further detailed evaluation at local levels in order to accurately define the most suitable specific locations. These localities will have to be (1) mapped in detail and seismically monitored to delineate active fault zones and areas of crustal unrest, (2) surveyed by geophysical techniques (where applicable) to locate buried fautts and to better define subsurface conditions and (3) drilled and hydraulicaliy tested to locate the zones having the lowest permeabilities. Finally, the drill core will have to be analyzed physically and chemically in order to predict the nature of the rock-waste interaction.

\subsubsection{Basic Description of Earth System}

A1 1 the geologic waste disposal concepts considered in this investigation involve emplacing waste in the earth's crust, which is the outermost layer or shell of the earth (Figure 4.2). Knowledge that the earth is made up of various layers is based principaliy on the behavior of seismic or earthquake waves as they pass through the earth. The crust of the earth ranges in thickness from about 5 kilometers in some places under the oceans to more than $50 \mathrm{kilo-}$ meters under high mountain ranges, such as the Sierra Nevada. In the continental parts of the United States the crust everywhere exceeds the maximum thickness or depth considered for the deep drili-hole concept (16 kilometers).

The continental crust is made up largely of light-colored igneous rocks such as granite, and the oceanic crust is made up almost entirely of basalt, which is darker and heavier than granite. The crust overlies a layer called the mantle which, in turn, overlies the earth's core.

The composition of the mantle as contrasted to the crust is $1 \mathrm{itt} 1 \mathrm{e}$ known. Knowledge of mantle composition is theorized from studies of volcanic lava and of the composition of diamond pipes and from laboratory experiments on minerals and rocks. These studies and seismic data indicate that the rocks of the upper mantle are denser than the crustal material and are composed most $1 y$ of iron and magnesium silicate minerals. In the lower mantie, because of very high pressure, only the simple oxides of iron, magnesium and silicon are thought to be present. (2) 

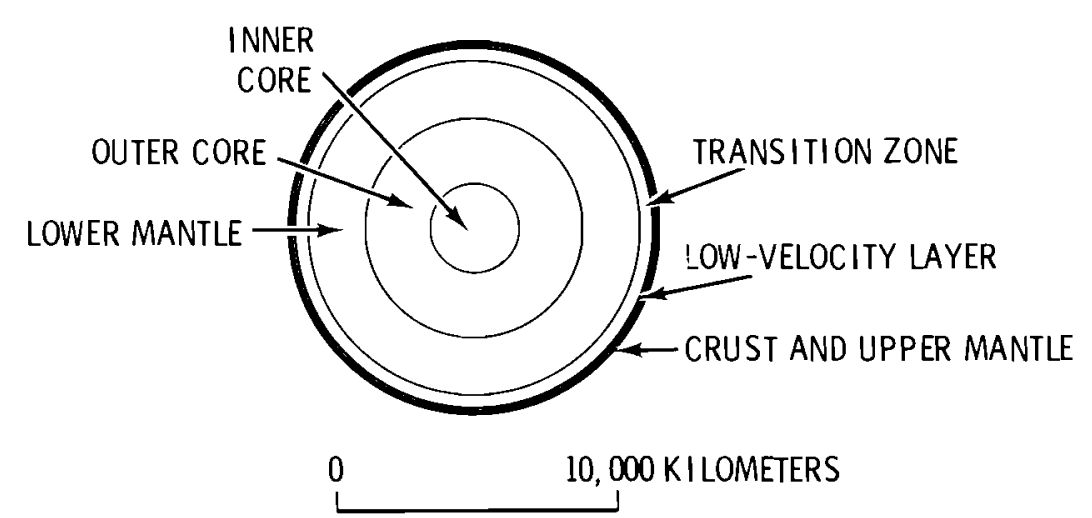

CROSS SECTION OF THE WHOLE EARTH, SHOWING CORE, MANTLE, AND CRUST

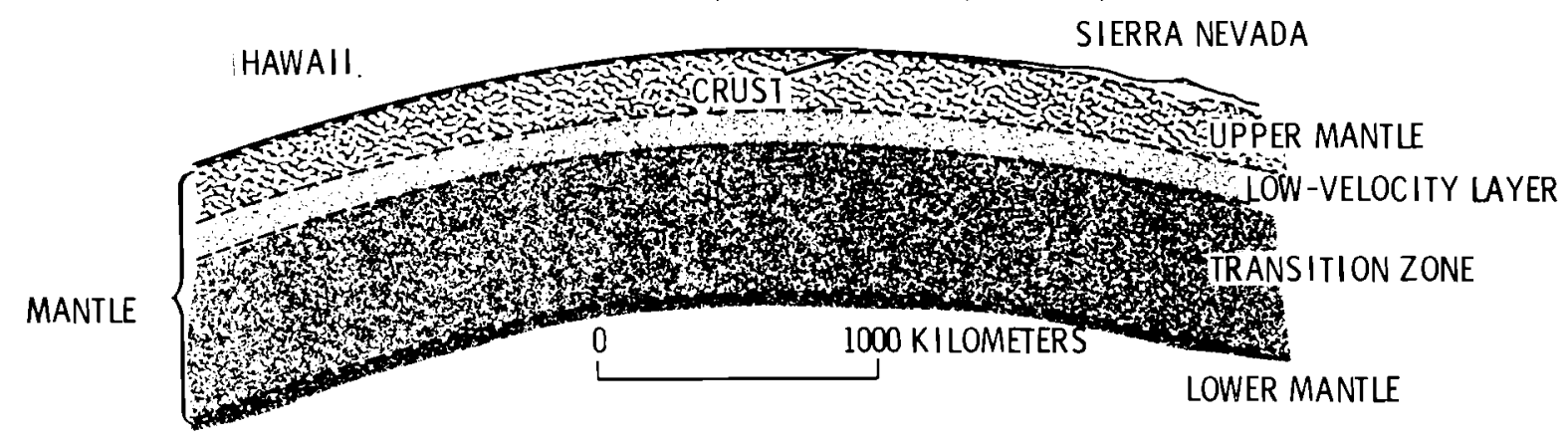

UPPER MANTLE AND CRUST BETWEEN HAWAII AND CALIFORNIA. THE CRUST IS VERY THIN RELATIVE TO THE REST OF THE EARTH.

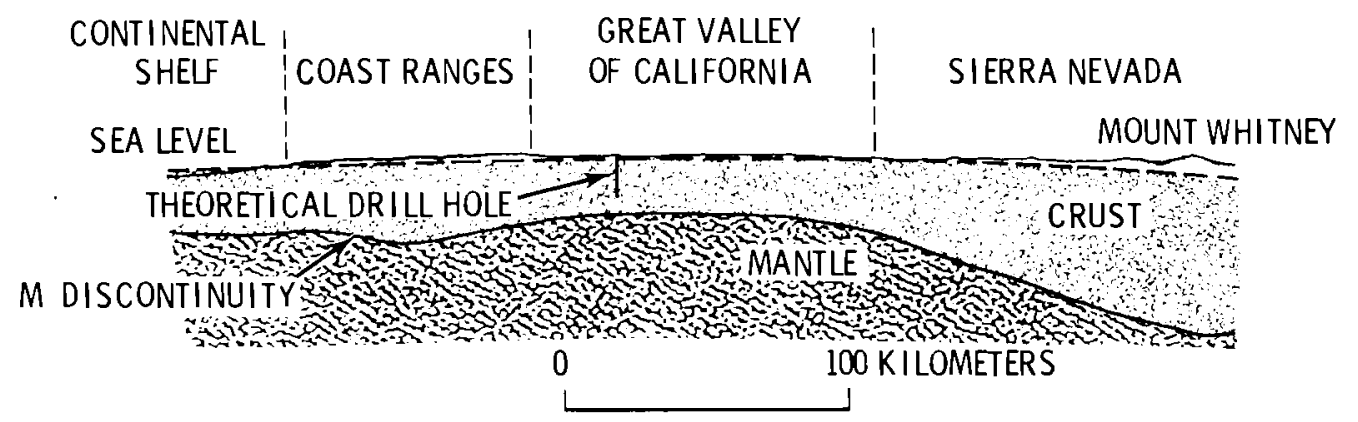

CONTINENTAL CRUST UNDER CALIFORNIA, SHOWING CRUSTAL THICKENING UNDER THE SIERRA NEVADA AND 15-KILOMETER DRILL HOLE

\section{FIGURE 4.2. Cross Sections of the Earth and Parts of the Earth's Crust and Mantle (Modified from
Robertson, 1966 ) $(2$ )}

Below the mantle is the earth's core, which is divided into an outer part and an inner part as shown on Figure 4.2. The outer core is presumed to be liquid because it does not transmit shear waves (earthquake waves in which particle motion is across, or transverse to, the direction of travel), and because it sharply reduces the velocity of compressional waves (earthquake waves in which particle motion is back and 
forth parallel to the direction of trave1). The inner core, detached because of its higher compressional wave velocity, is considered to be solid. The core occupies about 15 percent of the earth's volume, the mantle about 84 percent, and the crust on ly about 1 percent. (2)

of concern to waste disposal in Western United States is the knowledge that the Pacific Ocean and coastal California west of the San Andreas fault system is moving relatively northwestward with respect to the remainder of the United States at a rate estimated at from 5 to $8 \mathrm{~cm} / \mathrm{yr}$ ( 2 to 3 inches per year). (3) This movement breeds the earthquakes that shake California and is an example of tectonic activity that affects the entire globe. The science of this global tectonic activity is generally referred to as "plate tectonics."

Not only are southern California and the Pacific moving northwestward with respect to the North American plate, but continents and ocean basins alike throughout the globe are slowly moving across the face of the earth at rates that are extremely slow in terms of a man's lifetime but are exceedingly fast in terms of geologic time.

knowledge gained on a global scale now allows earth scientists to divide the earth's crust and uppermost mantle into some eight major geological plates or caps. (4) The plates move out from midoceanic ridges and plunge downward into the great deeps or troughs of the ocean (Figure 4.3) in zones referred to as subduction zones. The midoceanic ridges are linear "rift" zones where rock material from the earth's interior wells up to form new crust and then spreads outward on both sides of the ridge. This process is referred to as "sea-floor spreading." That the floor is indeed spreading has been confirmed by magnetic and fossil data which show that the ocean floor is youngest at the midoceanic ridges or divides and becomes progressively older outward in both directions. The continents gradually move away from the spreading ridges. It is inferred that about 200 million years ago the continents were al1 part of a single land mass or super continent.

Subduction zones (Figure 4.3) and other plate-junction zones are belts of major earthquake and volcanic activity. of principal concern in evaluating geologic waste disposal in the western United States is the junction of the Pacific and the North American plates along the San Andreas fault, which connects offset segments of the East Pacific Rise. The significance of movement along this junction from the standpoint of waste disposal is the fact that at the present rate southern California west of the San Andreas fault will move northwestward relative to the remainder of the continent at least 50 kilometers (30 miles) in a 1 million year period.

The San Andreas fault projects northward off-shore from California to intercept the east-trending Mendocino fracture zone. It is not clear what happens to the San Andreas at this junction. Neither the Mendocino fracture zone nor the San Andreas system offsets the other. (5) North of 


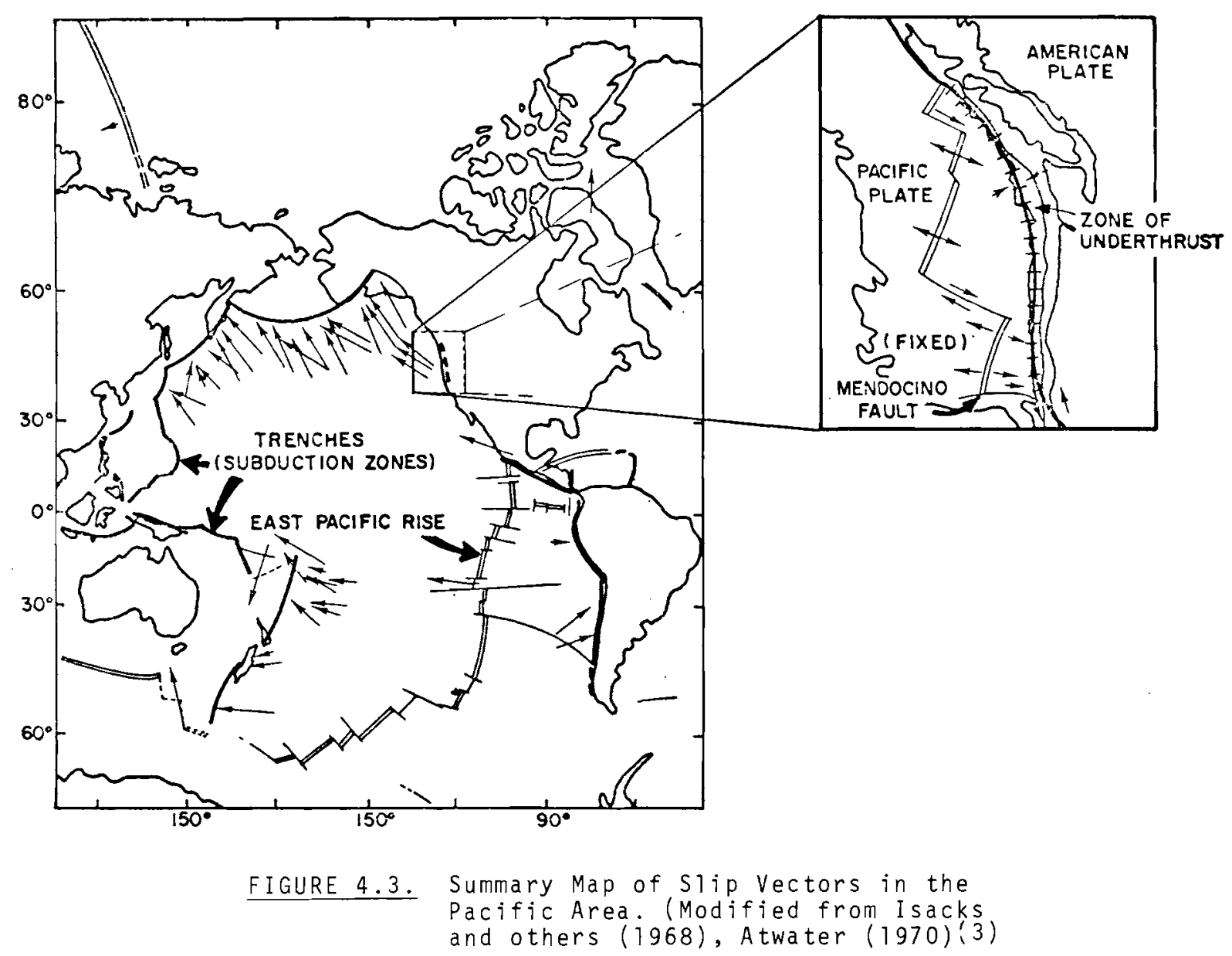

the junction, the East Pacific Rise is present (Figure 4.3) and is spreading at a rate of 5 to $8 \mathrm{~cm} / \mathrm{yr}$ (2 to 3 inches per year). ( 3 ) This motion and the possibility that the coasts of Oregon and washington are being underthrust by the ocean floor $(6-8)$ indicate that the lack of major earthquakes in that locality may not be a permanent condition. The development of tight folds in the Columbia Plateau and the indication of continuing crustal unrest in that region may be related directly or indirectly to the interaction of the oceanic and continental plates, and the next 1 million years could see an increase in tectonic activity in the northwestern part of the United States.

The disposal of waste is a special problem in each environment, and the occurrence of suitable rock types and favorable local geohydrologic conditions will dictate whether a particular area is suitable for waste disposal. However, certain general considerations must be evaluated for a 11 sites and are of primary concern. These considerations are: (1) 1 ithology, (2) hydrology, (3) geochemistry, (4) character of terrain and effects of erosion and rates of denudation 
(physiography), (5) seismicity,

(6) possible climatic changes, and

(7) resource potential. (a)

\subsubsection{Lithologic Considerations}

This section briefly describes the principal rocks found in the various geologic environments in the United States and presents tables of physical property data considered significant in evaluating waste disposal. The rocks include all the principal types found in the earth's crust. These are subdivided into three main categories: sedimentary, igneous, and metamorphic.

\subsection{Sedimentary Rocks.} Sedimentary rocks are those deposited on the earth's surface by the action of water, wind, accumulation of organic remains, or chemical precipitation. They are formed by the destruction (physical or chemical) of preexisting rocks, either igneous, sedimentary, or metamorphic. The principal sedimentary rocks are shown in Table 4.1.

Among the various sedimentary rocks there are extreme variations in physical properties, but, in general, the sedimentary rocks tend to be the weakest rocks in the crust and, exclusive of salt, have the greatest ability to store and transmit groundwater. Although sedimentary rocks are estimated to constitute only 5 percent of the volume of the earth's crust, they are the rocks most likely to be encountered on the upper surface of the earth.
Sandstone and conglomerate consist of grains of quartz, feldspar, and rock fragments cemented together with silica, calcium, carbonate, clay, or combinations of these ingredients. Sandstone and conglomerate vary considerably in physical properties, but, in general, they are strong rocks that will support unpropped excavations. They are generally drilled with ease and mined with a minimum of problems and hazards. They are often porous, and the pore spaces, commonly interconnected, can allow rapid transmission of water.

Shale is a general term for lithified clay and mud. Most shale contains some sand. Some geologists restrict the term to rock that breaks or weathers to tiny flat fragments a fraction of an inch thick that are parallel to original bedding planes. Most shale is weak and will not support unpropped excavations. It commonly contains swelling clays. It creeps in outcrop and "flows" under loading. It is, in general, a poor foundation rock and it is extremely difficult to drill and mine. The amount of "chimneying" above an underground nuclear blast in shale can be predicted to be extreme unless strong interbeds of sandstone or limestone are present. Shale, however, has the lowest permeability of sedimentary rocks. it has the highest ionexchange capacity, and, under certain conditions, may be a suitable host for waste disposal.

a. Item (7) is included by the staff of Pacific Northwest Laboratories (PNL). 
TABLE 4.1. Principal Sedimentary Rocks

$\begin{array}{ll}\text { Method of formation } & \frac{\text { Rock }}{\text { Mechanical }} \\ & \text { Sanglomerate } \\ & \text { Shale } \\ \text { Chemical } & \begin{array}{c}\text { Carbonate } \\ \text { (1imestone and } \\ \text { dolomite). }\end{array}\end{array}$

Salt

Organic Limestone, coal

Description
Almost entirely cemented
gravel
Cemented sand
Cemented mud and clay
Chemically precipitated
but commonly reworked
grains of calcite and
dolomite with admix-
tures of mud and sand

Fossiliferous calcite reconstituted plant rema ins
Sedimentary carbonate rocks are called limestones if composed predominantly of calcite $\left(\mathrm{CaCO}_{3}\right)$; they are called dolomite if abundant $\mathrm{CaMg}\left(\mathrm{CO}_{3}\right)_{2}$ is present. Carbonate rocks are water soluble in a variety of temperature-pressure conditions in the shallow subsurface and, consequently, form the famous cave areas of the world. In some areas, for example, in the Basin and Range province of the western United States, the carbonate rocks at great depths can be prolific water bearers with extremely high permeabilities. In other areas, for example, the Balmat-Edwards area of New York State, carbonate rocks have very low permeabilities even in the shallow subsurface. (9) They are strong rocks but their local high permeabilities and chemical instabilities would be considered a major disadvantage for waste storage or disposal.

Salt ( $\mathrm{NaCl}$ ) forms in basins that become isolated or partly isolated from the sea. It occurs in relatively pure beds, in thin layers interbedded with sediments and other evaporites, and in domes. Salt has several properties that are favorable for waste disposal. These properties, according to a report prepared by a committee on radioactive waste management of the National Academy of Sciences, (10) are:

1. Natural plasticity that will effectively seal the waste canisters in cells and will relieve stress concentrations produced by the mining operations

2. High compressive strength

3. Thermal conductivities that permit the dissipation of larger quantities of heat 
4. Gamma-ray shielding properties similar to concrete

5. Very low porosity and permeability which provide for isolation from man's environment.

In addition to the National Academy of Sciences' National Research Council study(10) many other investigations on the feasibility of using salt for repositories for radioactive waste have been completed (see selected References 11-22). These investigations were generally concerned only with shallow depth burial concepts. At shallow depth (about 1,000 meters or less) the natural plasticity of salt is not considered to pose problems for either cavity construction or long-term disposal of waste. At depths greater than about 1,000 meters, however, the ability of salt to flow may pose problems for waste disposal either in drill holes or in cavities. Many holes have been drilled in salt to depths of at least 4,000 meters. (21) No serious dri11ing problems have been reported. The possibility exists, however, that large-diameter holes not filled with drilling mud and large mined or explosion-induced cavities would not remain open for any appreciable period at depths much below a thousand meters.

Another consideration regarding the use of salt for waste disposal is the high solubility and the attendant danger of exposing the waste if the salt is attacked by groundwater. Dissolution of salt formations at shallow depths by circulating groundwater is a common phenomenon. To ensure the long-term containment of the waste in the salt, it would be necessary to establish the nature and rates of salt removal near each site.

In principle, salt domes of proven stability should be considered equally as feasible as bedded salt deposits for the disposal of radioactive waste. The National Academy of Sciences' Committee on Waste Disposal (10) made no distinction between salt domes and bedded formations as suitable prospects for waste disposal. Since that time, the studies made by ORNL and others $(11-21)$ on the general suitability of salt for the purpose of radioactive waste disposal have not revealed fundamental reasons for favoring bedded salt over domal structures or vice versa. (a)

There are several potential problems in selecting salt domes and, more importantly, in demonstrating the suitability of any specific dome as a site for radioactive waste disposal. These problems are related to determining the geometry of domes; establishing the tectonics of salt domes (diapirism); the hydrological regime associated with domes; the thermal and temporal effects on the tectonics and hydrology; and the $1 \mathrm{im-}$ ited geographic distribution of salt domes which would also have the necessary surface conditions suitable for

a. This paragraph plus the remainder of the section up to 4.0.3.2.2 Igneous Rocks presents material prepared by the Pacific Northwest Laboratoriesi staff. 
a waste disposal site (i.e., available land, remoteness, no

groundwater).

Salt domes can be very irregularly shaped. $(18,21)$ It would be necessary to accurately establish the geometry of any specific salt dome considered for waste disposal, primarily to assure that the disposal cavity would not too closely approach the dome edge and thereby possibly break through with a resultant inflow of water. To establish the necessary width of the barrier between the salt dome edge and a proposed disposal cavity would require a considerable research and design effort on each specific dome.

In regards to the tectonics of salt domes, it is generally agreed that domes have resulted from the upward intrusion of large volumes of salt from source beds buried at greater depths (diapirism). (18) The average velocity of emplacement is probably no more than a few millimeters per year and some of the domes may still be moving at that rate. (18) Before a particular dome could be considered suitable for waste disposal, it would be necessary to demonstrate that it is presently stable, that past movement had not produced any residual stress concentrations, and that rejuvenated movement affecting the waste disposal system would not likely occur over the next one million years.

Because salt domes occur by intrusion through overlying sediments, they are not generally protected from potential dissolution by circulating groundwater. The anhydrite (calcium sulfate) "cap rock" immediately overlying most salt domes in the Gulf Coast region is believed to be the insoluble residue left by the dissolution of as much as a thousand meters of the original dome. (18) Site investigations for waste disposal in a specific salt dome would have to define the characteristics of the groundwater system around the dome in considerable detail in order to demonstrate that further dissolution would not occur. A further consideration in this respect is the possibility of encountering a zone of higher permeability rock inside the dome that could be hydrologically connected with the groundwater systems.

In order to assure adequate containment of waste products over their toxic lifetime if disposal is made in a salt dome, consideration will also have to be given to the future effects of cavity excavation and added heat from radioactive decay on both the tectonic and hydrologic systems. Salt is quite plastic and when occurring in domes is already in a high potential state of mobility. It would be necessary to demonstrate that renewed diapirism would not occur from movement of salt into the cavity; from response to the wider induced stress field in the case of an explosion formed cavity; or from the stress that would be induced by added heat from the waste products over periods of several hundreds of thousands of years.

Geographically, salt is distributed over several large regions of the United States. Individually 
salt domes cover a relatively small area within any given basin. Consideration would therefore have to be given to finding a salt dome with suitable subsurface characteristics that also had satisfactory surface features. In the Gulf Coast region where most of the salt domes are known to occur, the surface land is already committed to production of $0 i 1$ and gas, to mining salt from the domes, or to agricultural use because of the shallow and prolific surface water systems.

\subsection{Igneous Rocks. Igneous} rocks are those formed by the solidification of molten rock. They include intrusive (plutonic) rocks that solidified below the earth's surface at various depths, and extrusive (volcanic) rocks that solidified after being erupted onto the earth's surface. The intrusive rocks are fine, medium, or coarse grained depending upon the depth of intrusion, rate of cooling, and presence of gaseous constituents. The extrusive rocks are fine grained or glassy (with or without crystals) and are subdivided into 1) lavas--rocks formed from 1 iquid magma that flowed directly onto the earth's surface and 2) tuff--rocks that formed from eruptive ash that either flowed directly onto the earth's surface from a volcanic vent (ash-flow tuff) or fell from the atmosphere after being explosively erupted into the air from a volcanic vent (ash-fall tuff). Igneous rocks are commonly classified on the basis of their texture (grain size), minerals present, and the abundance of silica $\left(\mathrm{SiO}_{2}\right)$. A general classification and the principal mineral assemblages of igneous rocks are shown in Table 4.2 .

The igneous rocks vary individually in hardness and strength dependent upon crystal size, the mode of eruption, and the presence or absence of voids. The plutonic (intrusive) rocks have low porosities and permeabilities, whereas the volcanic (extrusive) rocks vary in these properties from very low to extremely high.

Plutonic igneous rocks which consist of granite, granodiorite, diorite, gabbro, and other varieties can be generally regarded as a single rock type from the standpoint of mechanical strength and overall suitability for waste disposal. The granitic rocks, however, have the lowest melting points and are somewhat weaker than the other rocks in this category. Because of 10 porosities and permeabilities and high mechanical strengths, the plutonic rocks could be considered favorable for waste disposal.

Volcanic igneous rocks are the fine-grained (extrusive) equivalents of the plutonic (intrusive) rocks. Although some volcanic rocks are chemically identical to some plutonic rocks, their physical properties are, in general, decidedly different, and, a though lavas and tuffs may have identical chemical compositions, they generally differ significantly in physical properties.

Throughout the United States lavas occur that vary in composition from rhyolite to basalt, and although the various lavas have many features in common, they display some inherent 
TABLE 4.2. General Classification and Principal Mineral Assemblages of Igneous Rocks

\begin{tabular}{|c|c|c|c|c|}
\hline Texture & $\begin{array}{c}>66 \text { percent silica } \\
\text { (acid) }\end{array}$ & $\begin{array}{l}52-156 \text { percent } \\
\text { (intermedt. }\end{array}$ & $\begin{array}{l}\text { silica } \\
a(e)\end{array}$ & $\begin{array}{c}<52 \text { percent silica } \\
\text { (basic) }\end{array}$ \\
\hline 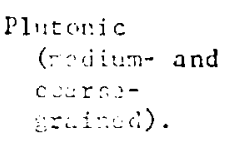 & Granite & Gramodiortte & Diorite & Caubro \\
\hline \multirow[t]{2}{*}{$\begin{array}{l}\text { Volcanic (fine- } \\
\text { graincd or } \\
\text { glassy lava } \\
\text { o: Euts). }\end{array}$} & Rhyo11te & $\begin{array}{l}\text { Quartz latite } \\
\text { and } \\
\text { rhyodacite. }\end{array}$ & $\begin{array}{l}\text { Dacite and } \\
\text { andesite. }\end{array}$ & $\begin{array}{l}\text { Basalt and basa } 1 t 1 \mathrm{c} \\
\text { andesite. }\end{array}$ \\
\hline & $\begin{array}{l}\text { Wa jor minerals- } \\
\text { quartz, potassium, } \\
\text { feldspir, mica. }\end{array}$ & $\begin{array}{l}\text { Mijor minerals-- } \\
\text { quartz, } \\
\text { sodiuri-calcium } \\
\text { feldspar, mica, } \\
\text { amphibole. }\end{array}$ & $\begin{array}{l}\text { Ma jor minerals-- } \\
\text { calcium-sodium } \\
\text { feldspar, mica, } \\
\text { amphibole. }\end{array}$ & $\begin{array}{l}\text { Major minerals-- } \\
\text { calcium-sodium } \\
\text { feldspar, } \\
\text { pyroxene, } \\
\text { ollutne. }\end{array}$ \\
\hline
\end{tabular}

differences that would be significant to waste disposal. Rocks that are rich in $\mathrm{SiO}_{2}$ or contain intermediate amounts of $\mathrm{SiO}_{2}$ are erupted at lower temperatures than the basalts and other similar low-silica lavas, and they are much more viscous. Because of greater viscosity, these lavas move across the earth's surface slowly, congealing and freezing on the flanks, at top, and base and become flow contorted and brecciated (broken fragments cemented by finer grained materials). The brecciation increases the porosity and permeability of the rock, and, consequently, many of the silicic lavas are prolific water bearers. Although they are strong rocks except where they are extensively brecciated, and although they are easily mined and drilled, most silicic lavas would be considered unfavorable for waste disposal or storage. The basaltic and other low-silica lavas are erupted at higher temperatures and are more fluid. They commonly solidify without extensive brecciation except at top and base. Individual flows, however, are often thin (less than 60 meters) and the brecciated contacts between flows are consistently zones of high porosities and permeabilities.

Tuffs solidify from soft ash by a process called welding, which is a result of heat and load pressure, and by bonding of matrix material by secondary processes during burial beneath the water table. The degree of welding is the principal factor that controls the hardness of the tuffs. Densely welded tuffs have physical properties that are similar to those of lavas. Partially or nonwelded tuffs are similar to soft sandstones. Porosity in tuffs is dependent on the degree of welding and the amount of 
alteration or secondary crystallization that occurred during and after cooling, including zeolitization.

Most tuffs have more than 20 percent open pore space (porosity) but they also tend to have lower permeabilities than most lavas because the pore spaces are not extensively interconnected. The tuffs are easily drilled and mined. They have the highest ionexchange capacities of all the igneous rocks. Where sufficiently thick and not faulted the tuffs could provide potential media for waste disposal.

\subsection{Metamorphic Rocks.} Metamorphic rocks are formed from original igneous, sedimentary, or other metamorphic rocks through alterations produced by pressure, heat, or introduction of other materials at depths below the surface zones of weathering and cementation. They are more or less reconstructed in place while remaining virtually solid. New minerals and textures come into being and are stable under conditions that produce the change. (23) Grain sizes, compositions, and derivations of the principal metamorphic rocks are given in Table 4.3. Quartzites, marbles, and amphibolites are unfoliated to faintly foliated, whereas the other types are foliated, cleaved, or banded, and some types (especially slate) tend to split in well-defined thin layers. All these rocks are considered to be stronger than their sedimentary equivalents and have lower permeabilities, but, in general, they are weaker and have higher permeabilities than most intrusive igneous rocks.
In general, there are often no sharp boundaries between the various types of metamorphic rocks. Within a small area several rock types may occur; therefore, locating a particular metamorphic type at depth often requires more intense surface and subsurface investigations than is normally required for intrusive igneous (plutonic) rocks.

Quartzites are made up of interlocking grains of quartz. They are essentially extremely well cemented quartz sandstones. When fractured, quartzites break across the grains in contrast to sandstones which break around the mineral grains. Quartzites are very hard, are chemically inert, and have the highest thermal conductivity and thermal expansion of the principal rock types discussed. Most quartzites have very low porosity and permeability. Their susceptibility to fracturing, however, increases their permeability, especially at shallow depths. At greater depths, quartzites could be more favorable for the disposal of waste because fractures would tend to be closed.

Marbles are recrystallized limestones or dolomites, and their chemical and physical properties do not differ markedly from these sedimentary rock types. They have the greatest solubility of the metamorphic rocks and are chemically unstable in an acid environment and at higher temperatures. Because of their chemical instability and potential for locally high permeabilities in most geohydrologic environments, marbles would be generally unsuitable for waste disposal. 
TABLE 4.3. Principal Metamorphic Rocks

\begin{tabular}{|c|c|c|c|}
\hline Rock Type & Grain Size & Chief Minerals & Derivation \\
\hline Gneiss & $\begin{array}{l}\text { Coarse to medium } \\
\text { grained }\end{array}$ & $\begin{array}{l}\text { Quartz, feldspar, } \\
\text { mica, hornblende }\end{array}$ & $\begin{array}{l}\text { Granite, mica, } \\
\text { schist, shale }\end{array}$ \\
\hline Quartzite & $\begin{array}{l}\text { Coarse to medium } \\
\text { grained }\end{array}$ & Quartz & Sandstone \\
\hline Amphibolite & $\begin{array}{l}\text { Coarse to medium } \\
\text { grained }\end{array}$ & $\begin{array}{l}\text { Hornblende, } \\
\text { plagioclase, minor } \\
\text { garnet and quartz }\end{array}$ & $\begin{array}{l}\text { Basalt, gabbro, } \\
\text { tuff }\end{array}$ \\
\hline Marble & $\begin{array}{l}\text { Coarse to fine } \\
\text { grained }\end{array}$ & Calcite, dolomite & Limestone, dolomite \\
\hline Schist & $\begin{array}{l}\text { Coarse to fine } \\
\text { grained }\end{array}$ & $\begin{array}{l}\text { Mica, quartz, } \\
\text { feldspar }\end{array}$ & Shale, igneous rocks \\
\hline Phyllite & Fine grained & $\begin{array}{l}\text { Mica, quartz, } \\
\text { kaolinite }\end{array}$ & Shale, tuff \\
\hline Slate & Very fine & Mica, kaolinite & Shale, tuff \\
\hline
\end{tabular}

Most amphibolites are coarsegrained rocks consisting of amphibole and plagioclase and lesser amounts of garnet, quartz, and epidote. They are derived from basalts, gabbros, and rocks of similar composition. Some are derived from impure dolomite. of the principal metamorphic rock types, amphibolites have the greatest strength and should be less susceptible to fracturing than quartzites, and, therefore, less permeable at shallower depths. Amphibolites also have the highest density and magnetic susceptibility of the common metamorphic rocks, which would be advantageous in determining their distribution through geophysical methods. The potential for very low permeabilites indicates that amphibolites could be suitable for waste disposal.

Gneisses have distinct layers or lenses of different minerals. The mineral composition, although variable, consists of abundant feldspar and moderate amounts of quartz, amphibole, garnet, and mica. Gneisses form from numerous parent rocks, igneous, sedimentary, or metamorphic. They a:e second to amphibolites in strength and second to quartzites in thermal conductivity. Because gneisses vary considerably in their mineralogy and origin, their physical and chemical properties generally are not consistent. Therefore, some varieties of gneiss could prove to be more favorable for waste disposal than others. Gneisses, in general, have very low permeabilities, but gneisses formed from igneous rocks tend to have lower permeabilities than those formed from sedimentary rocks.

Schists are crystalline metamorphic rocks having closely spaced foliation. They tend to split readily 
into thin flakes or slabs. There is a complete gradation between schists and gneisses to schists and slates.

The names of the varieties of schist are based chiefly on the mineral responsible for the foliation, that is, biotite schist, chlorite schist, and graphite schist. Schists have lower thermal conductivities than quartzites, amphibolites, and gneisses, and have the least strength of any of the principal metamorphic rocks. Because of their wide variation in mineralogy and origin, schists should vary considerably with respect to physical and chemical properties, and their favorability for waste disposal will depend on the rock type in question.

Phyllites are fine-grained foliated rocks that are intermediate between mica schists and slates. Practically all phyllites are derived from fine-grained sedimentary rocks by mechanical deformation and recrystallization. Fracturing is intermediate between the rather splintery fissility of schist and the smooth, even cleavage of slate. Both phylites and slates are highly foliated and, because of their excellent foliation, split into thin sheets.

slates are homogeneous metamorphic rocks so fine grained that no mineral grains are visible to the naked eye. Some slates split into slabs having plane surfaces almost as smooth as the cleavage planes of minerals. Slate is harder than shale, although the difference is slight. Slates and phyllites have the greatest ionexchange capacities of the common metamorphic rocks. Slates may 10cally be suitable waste disposal rocks from the standpoint of perme- . ability, especially at great depths where open fractures along cleavage planes may be at a minimum. Slates have the least thermal conductivity, and their thermal expansion is nearly as high as in quartzites.

Chemical compositions and additional physical and hydrologic properties of principal rock types (sedimentary, igneous, and metamorphic) are given in Appendix 4.C.

\subsubsection{Hydrologic Considerations}

Hydrology, specifically groundwater hydrology, is one of the most important considerations when planning for the ultimate disposal of high-level radioactive waste, because groundwater flow systems are the primary means by which waste constituents might regain contact with man's environment. Basically, where a hydraulic gradient is developed by difference in head, groundwater has the potential to move from areas of high head toward areas of lower head. If this potential exists and if avenues for movement are open, a groundwater flow system is established.

\subsection{Flow systems. Fig-} ure 4.4 illustrates basic patterns of groundwater flow in sedimentary basins under rather uncomplicated conditions and shows how contaminants could regain contact with man's environment even if placed in the deeper parts of the basins. Water enters permeable rock in areas of outcrop and travels downward, then laterally through the rock by gravity. In some basins, if permeable rock is overlain 


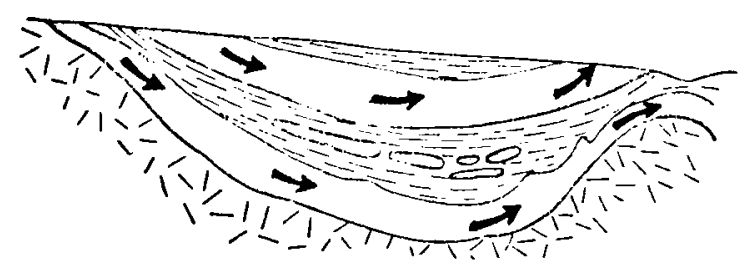

GRAVITY FLOW THROUGH IDEALIZEO BASIN

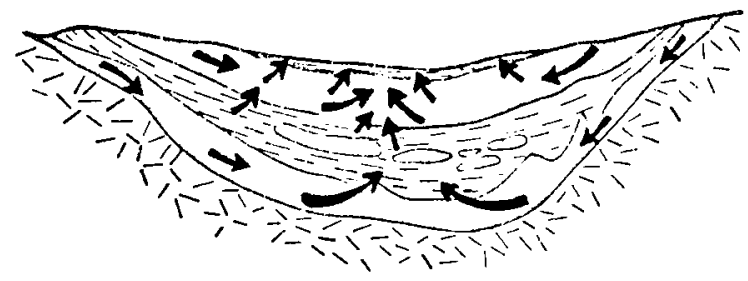

GRAVITY FLOW TOWARD CENTER OF BASIN

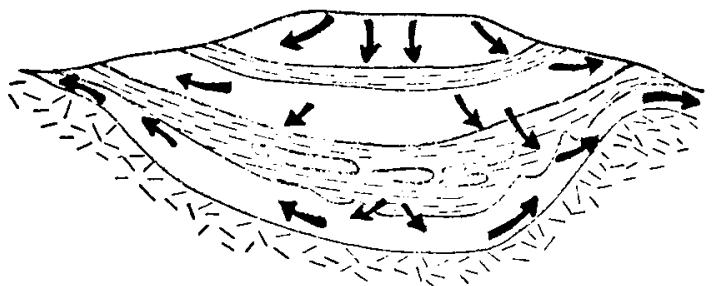

GRAVITY FLOW TOWARD SIDES OF BASIN

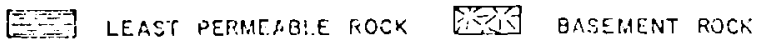

$\longrightarrow$ MOST PERISFLULE FOCK $\longrightarrow$ FLOW

FIGURE 4.4. Idealized Gravity Flow Through Basin

by relatively low permeability rock, artesian conditions can develop; this could create especially hazardous conditions for waste disposal.

The sedimentary basins in the United States are far more complicated than these diagrams indicate, and it is apparent that a thorough knowledge of hydraulic conditions in any basin considered for waste disposal is absolutely essential. Figure 4.5 shows the principal consolidated and unconsolidated groundwater systems in the United States and the surface drainage systems that are an important factor in controlling hydraulic conditions. It can be seen that the recharge source for a given basin can come from long distances and be affected by a variety of surface processes not indigenous to the basin.

Damming of rivers for the purposes of flood control, power production, or irrigation has been known to cause significant changes in associated groundwater systems. The major withdrawals of groundwater for irrigation (San Joaquin Valley, California; New Mexico; Texas; and Eastern Washington) has caused a lowering of the water table and an increase in hydraulic gradient. Other areas may show a marked increase in shallow 


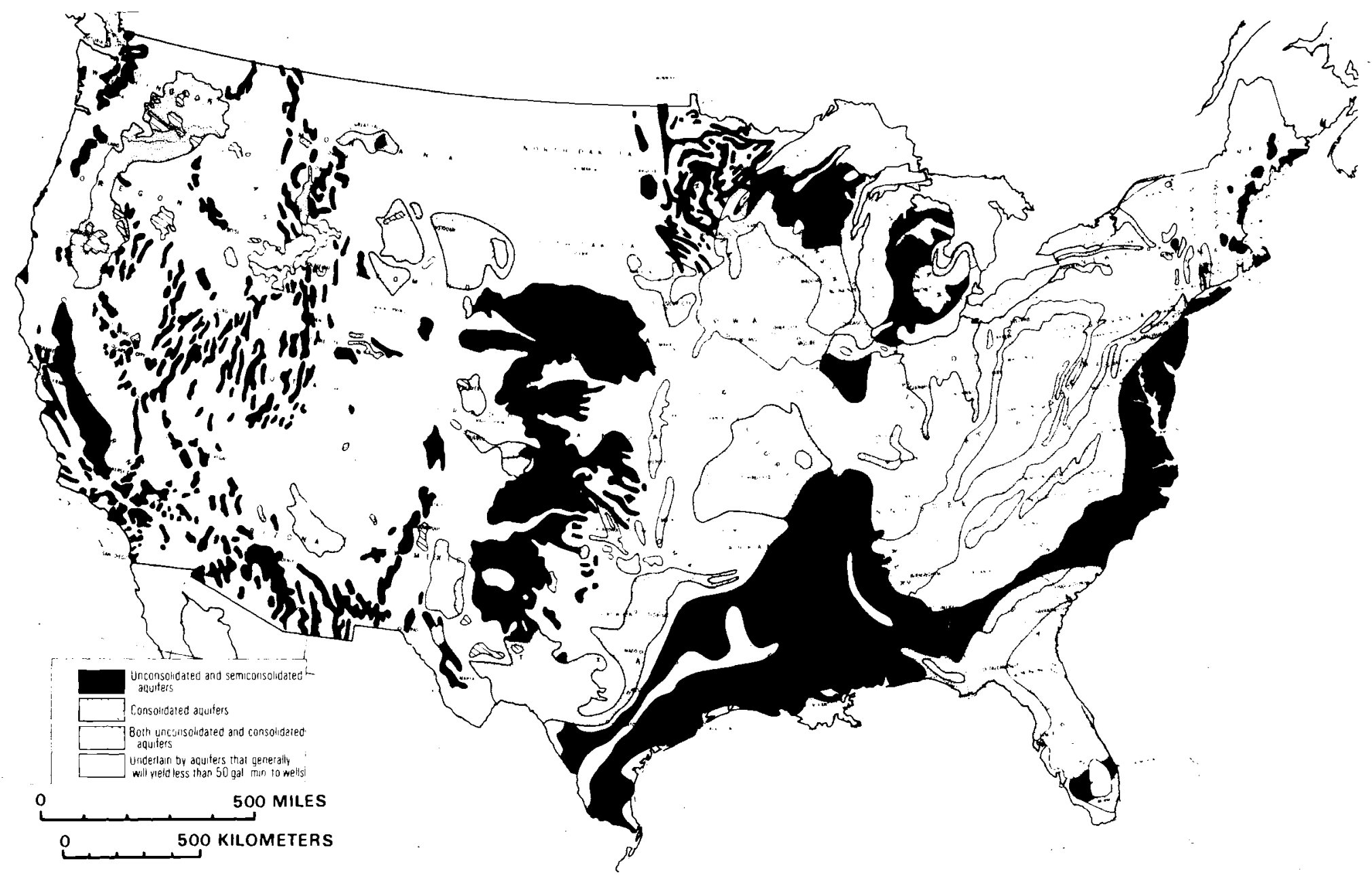


groundwater levels when the soils are impermeable and infiltration rates are too low to readily accommodate the increased water from irrigation and damming. These changes in the hydraulic system caused by man's manipulation of his environment are often difficult to predict because of the relatively slow travel time of groundwater. To foresee the changes that man may enact in the future and also predict the attendant changes in the groundwater systems will be even more difficult.

\subsection{Stratification and}

Faulting. Groundwater flow systems as discussed in the previous section are ideal and can be complicated by a disruption of the geologic framework of the system. The basic flow pattern through a basin usually is complicated, at least locally, by stratification and faulting. Stratification can change the direction of groundwater flow. Faults (fractures along which there has been relative displacement of the rocks) significantly affect flow patterns in any groundwater system. They can either be conduits for flow of water between transmissive zones or be obstructions to flow of water in an aquifer. Faults that are potential conduits of flow have been found at depths of one thousand or more meters. These faults are potentially hazardous to waste containment because they can serve as connections between disposal sites and man's environment even in an otherwise dense rock of very low permeability. Therefore, any site selected for disposal of waste must be hydrologically iso- lated from permeable fault systems. Thermal springs, commonly associated with volcanic rocks, can be surface expressions of faults. Certainly thermal springs are an indication of permeability and rather rapid groundwater circulation at depth. Conversely, absence of thermal springs does not necessarily suggest impermeable rocks below.

4.0.3.3.3. Permeability. Of principal concern for the safe emplacement of high-level radioactive waste is the permeability of the rock media. Permeability, as used in this study, is a measure of the ability of a rock to allow movement of water through its connected openings. Permeability (hydraulic conductivity) is described by Lohman and others (26) as follows: "If the porous medium is isotropic and the fluid is homogeneous, the medium has a hydraulic conductivity of unit length per unit time if it will transmit in unit time a unit volume of water at the prevailing kinematic viscosity through a cross section of unit area, measured at right angles to the direction of flow, under a hydraulic gradient of unit change in head over unit length of flow path." Permeability is a property of rock that has been measured frequently and, as such, can be discussed with some confidence in terms of general rock types. Table 4.4 defines degrees of permeability for use in later discussion of geohydrologic environments and rock and soil types.

\subsection{Liquid-Versus Solid-} Waste Disposal. In consideration of 


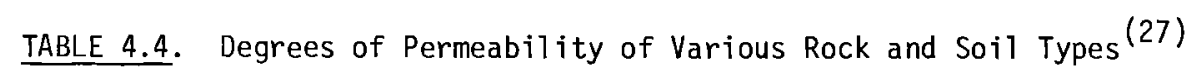

[By G. A. D1nw1dd1e, 1973, U.S. Geolog1cal Survey]

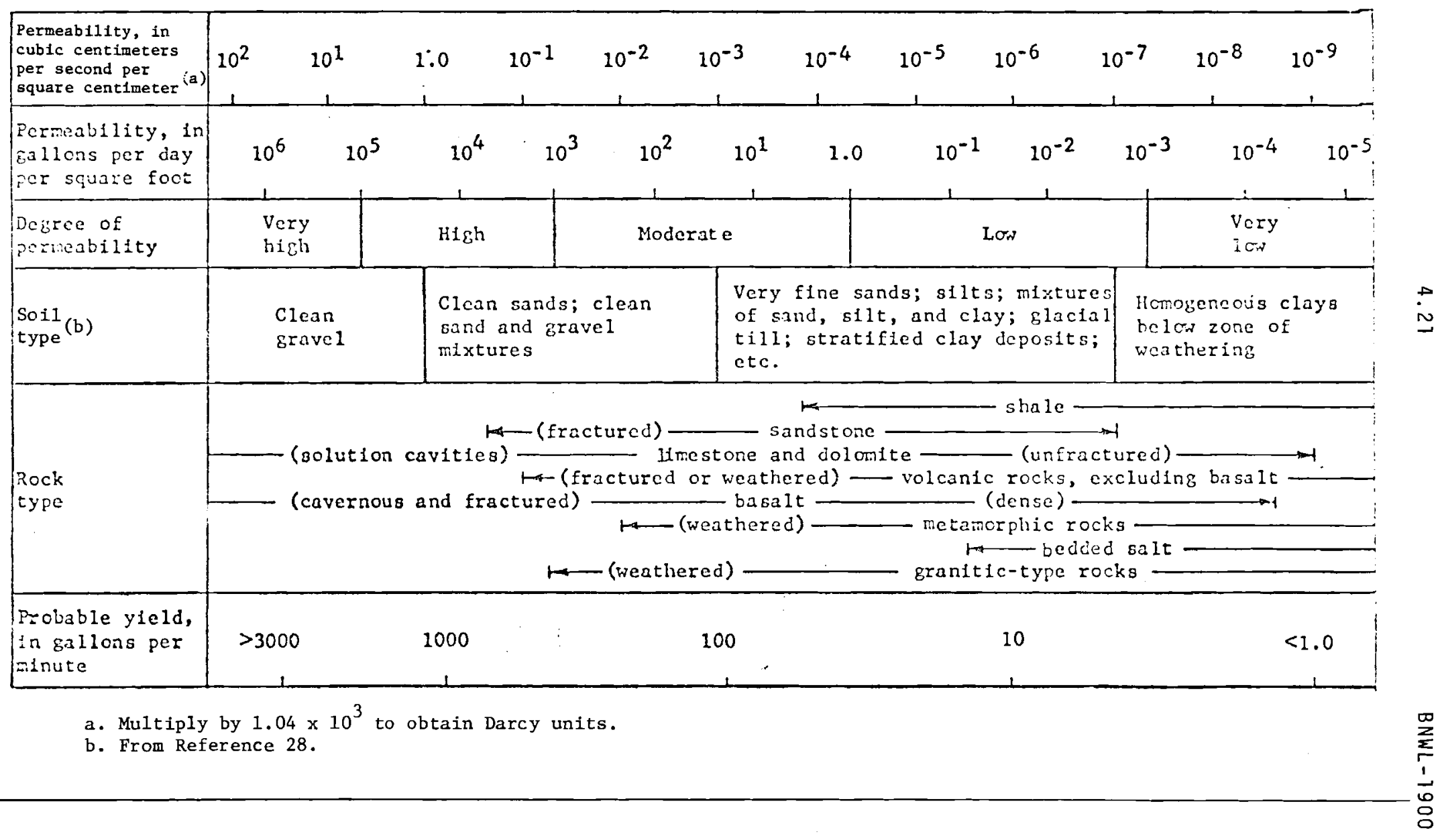


groundwater flow systems as limiting factors for planning the ultimate disposal of high-level radioactive waste, it is necessary to evaluate whether underground emplacement of liquid waste is hydrologically feasible in any geologic environment and, if it is, to consider the relative hazards of liquid-and solid-waste emplacement.

Liquid-waste disposal presents some obvious problems. Any plan to inject or place liquid waste within sedimentary rocks could be hazardous even if the waste first melts the host rock and then solidifies with the rock. All sedimentary rock has some permeability--has some degree of ability to transmit water and thus to transmit waste contaminants.

The alternatives to sedimentary rocks for liquid waste disposal are dense, unfractured metamorphic and igneous rocks, including the basement rocks. Most of the metamorphic and igneous rocks are crystalline, and the hydrologic implications are that interstitial porosity and permeability are very low and that any significant permeability established in these crystalline rocks must be fracture permeability. The crystalline rocks are weathered and fractured at shallow depths, but below a depth of about a thousand meters the likelihood of encountering water-bearing fractures, especially in the granitic type rocks, is low because lithostatic pressure generally serves to keep fractures closed and to prevent formation of new tensile fractures. Therefore, the crystalline rocks seem to be much better hosts for all concepts of liquidwaste disposal than do sedimentary rocks. Secor (29) has presented arguments indicating that appropriate fluid pressures in sedimentary rocks of magnitudes observed in deep oil tests could serve both to form tension fractures and to open up previously formed fractures at great depth. Such a process potentially provides paths for the migration of groundwater. Determining the existence of the appropriate conditions would require hydrologic evaluation of the specific area including deep drilling and studies of existing mines.

Fractures might also develop as a result of melting and subsequent expansion of the host rock by high temperature liquid waste whether placed in an exploded cavity or a deep drill hole. Whether or not such possible fracturing would extend far into the rock and form potential avenues for escape of contaminants can only be evaluated by laboratory and smallscale field experiments.

Disposal of high-level radioactive waste as glassy or micro-crystalline solids in the initial phase of disposal appears an advantageous concept to assure waste confinement. The main advantage is that the radionuclides from the first contact with the host media are not subject to aqueous migration until such time that they are leached from the binding solids. An additional advantage is a much greater degree of safety during the period of waste emplacement. 
For all of the disposal concepts considered herein it is presumed that the waste canister would be leakproof during the period of waste emplacement and that final sealing of the hole will be complete. The sealant should be of such integrity that it will remain impervious for the long time period of concern. Because of the possibility that the above conditions can not be positively guaranteed, potential site localities containing permeable strata above the emplacement zone must always be regarded as less suitable than those localities where the rocks, from the surface through the emplacement zone, have very low permeabilities. (17)

\subsection{Groundwater Transport.} Radioactive contaminants can migrate from an underground source of contamination through groundwater systems. Fenske(30) discusses the phenomena of the migration of radionuclides away from sites of nuclear explosions in terms of radionuclide transport in groundwater. Important physical parameters of radionuclide transport include: (1) radioactive decay constants, (2) initial concentrations of contaminants, (3) dispersion and diffusion of radionuclides, (4) retardation of radionuclides by ionic sorption, and (5) velocity of groundwater. These same parameters are pertinent to the problem of transport of radionuclides away from a waste-disposal site.

Dispersion (spreading and dilution) of contaminants in groundwater is caused principally by variations in velocity within a groundwater system. The greatest dispersion will be in a system with the greatest range in velocity wherein movement paths are tortuous. Therefore, dispersion will be greater in heterogeneous, anisotropic host rock than in homogeneous, isotropic media. Certain portions of the groundwater system having velocities greater or less than the average velocity will tend to retard or slightly accelerate the first arrival of contaminants at terminal flow points relative to average groundwater velocity.

Retardation of radionuclides is any means by which the rate of migration of radionuclides is slowed to less than the rate of groundwater movement. The principal retarding effect is that of ion-exchange capacity. The initial effect of ion exchange is reduction of concentration of ions (such as radionuclides) in solution when these ions are exchanged with ions from the host rock. The final effect is elution (desorption) of the radionuclides from the host rock over relatively long time periods compared to initial sorption. The net effect is usually significant dilution of the ions in the water and significant delay in nuclide transport through the rock. Some experiments have been made to determine retarding effects of specific rock types on selected radionuclides. The results of these studies and an expanded discussion of retardation are presented in section 4.0.3.4.

Because radionuclides migrate within groundwater flow systems, the rate of groundwater movement is one of the principal controlling factors of the extent of migration. Velocity of groundwater movement is controlled 


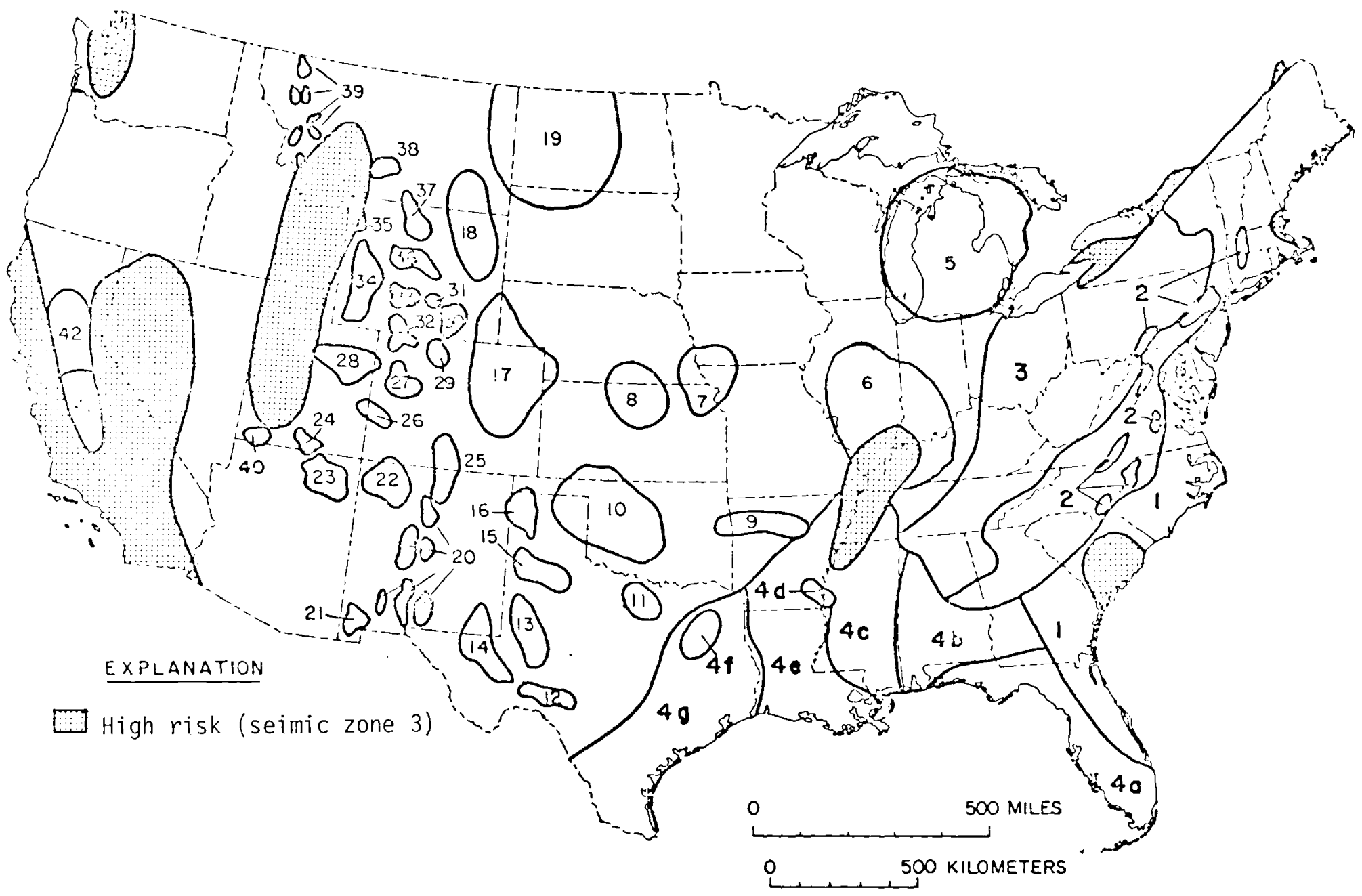

FIGURE 4.6. Locations of Sedimentary Basins

(Basins from Love and Hoover, 1961 (19)

and Seismic Risk from Algermissen,

$\sum_{2}^{\infty}$
$\frac{1}{1}$
0
0 
Key to Sedimentary Basin Locations in Figure 4.6

\begin{tabular}{|c|c|c|c|}
\hline $\begin{array}{c}\text { Map } \\
\text { number } \\
(\mathrm{Fig} \cdot 4.6)\end{array}$ & Basin & $\begin{array}{c}\text { Map } \\
\text { number } \\
(\mathrm{Fig} \cdot 4.6)\end{array}$ & Basin \\
\hline 1 & Atlantic Coastal Plain & 20 & Rio Grande basins, six \\
\hline 2 & $\begin{array}{l}\text { Eastern Triassic basins, } \\
\quad \text { eight }\end{array}$ & 21 & SW New Mexico basins, six \\
\hline 3 & Appalachian basin & 22 & San Juan basin \\
\hline 4 & Gulf Coastal Plain: & 23 & Black Mesa basin \\
\hline $4 a$ & Florida & 24 & Kaiparowits basin \\
\hline $\begin{array}{l}4 b \\
4 c\end{array}$ & $\begin{array}{l}\text { Alabama } \\
\text { Mississippi }\end{array}$ & 25 & San Luis basin \\
\hline $4 d$ & Desha & 26 & Paradox basin \\
\hline $4 e$ & Louisiana & 27 & Piceance basin \\
\hline $\begin{array}{l}4 f \\
4 g\end{array}$ & $\begin{array}{l}\text { Tyler } \\
\text { Texas Gulf }\end{array}$ & 28 & Uinta basin \\
\hline 5 & $\begin{array}{l}\text { Michigan basin, inluding } \\
\text { Canada }\end{array}$ & $\begin{array}{l}29 \\
30\end{array}$ & $\begin{array}{l}\text { North and Middle Parks } \\
\text { Laramie basin }\end{array}$ \\
\hline 6 & Illinois basin & 31 & Hanna basin \\
\hline $\begin{array}{l}7 \\
8\end{array}$ & $\begin{array}{l}\text { Forest City basin } \\
\text { Salina basin }\end{array}$ & 32 & $\begin{array}{l}\text { Washakie and Sand Wash } \\
\text { basins }\end{array}$ \\
\hline 9 & McAlester-Arkansas basin & 33 & Red Desert basin \\
\hline 10 & Anadarko basin & 34 & Green River basin \\
\hline 11 & Fort Worth basin & 35 & Jackson Hole \\
\hline 12 & Val Verde basin & 36 & Wind River basin \\
\hline 13 & Midland basin & 37 & Bighorn basin \\
\hline 14 & Delaware basin & 38 & Crazy Mountain basin \\
\hline 15 & Palo Duro basin & 39 & $\begin{array}{l}\text { Western Montana basins, } \\
\text { eight }\end{array}$ \\
\hline 16 & Dalhart basin & 40 & SW Utah basin \\
\hline 17 & Denver basin & 41 & San Joaquin basin \\
\hline 18 & Powder River basin & 42 & Sacramento basin \\
\hline 19 & $\begin{array}{l}\text { Williston basin, including } \\
\text { Canada }\end{array}$ & & \\
\hline
\end{tabular}


by effective porosity and permeability of the host rock and by hydraulic gradient. Within the scope of discussion of general rock types and geohydrologic environments, only permeability can be evaluated on a generalized basis.

\subsection{Sedimentary Basins.} The sedimentary basins throughout the United States (Figure 4.6) all owe their existence to downwarping and (or) downfaulting of the earth's crust. They differ individually in depth to basement rocks, in structure, and in geologic age. They are similar in that they are filled with relatively gently dipping sedimentary and, locally, volcanic rocks. They range in area from 2,500 to 250,000 square kilometers, and they range in depth from about 1,200 meters to more than 15,000 meters. Many of the younger basins in the western area of the United States and in the Coastal Plains contain unconsolidated sediments or slightly consolidated rocks. The older basins in the central and eastern areas of the United States contain mostly well consolidated rocks. Unconsolidated and slightly consolidated sand and gravel deposits are the predominant aquifers, especially in the western basins, $(32,33)$ but consolidated rocks such as sandstone, limestone and dolomite are also important aquifers in many areas.

Most of the sedimentary basins are important producers of oil, gas, or coal. Some produce salt, potash, ceramic clays, and various other nonmetallic and metallic minerals.

A generalized cross section through two typical sedimentary basins is shown on Figure 4.7 .

Groundwater. Groundwater occurs under both water-table and artesian conditions. At places where the aquifers are unconfined, groundwater occurs under water-table conditions, and water levels in wells do not rise above the top of the aquifer. (34) At places where the aquifers are confined by strata with very low permeability, such as shale, groundwater can occur under artesian conditions. There the water is under pressure so that the water levels in wells rise above the top of the aquifer. If the pressure is great enough, the well will flow at the land surface.

The water levels found in wells are generally shallower in areas of high precipitation or in areas of low topographic relief, such as basins in the eastern half of the United States. There water levels commonly range from above land surface (artesian) to shallow depths less than 30-60 meters. Water levels are generally deeper in areas of high topographic relief, such as basins in the western half of the United States. In those basins, water levels commonly range from above land surface to depths of 150 to more than 300 meters.

The movement of groundwater genera $11 y$ consists of recharge of water to an aquifer either from precipitation or from seepage from streams. This recharge moves downward and laterally under the forces of gravity and hydrostatic pressure through the aquifer toward points or areas of discharge. Discharge generally occurs in springs, in areas of evaporation and transpiration by plants, or by subsurface 


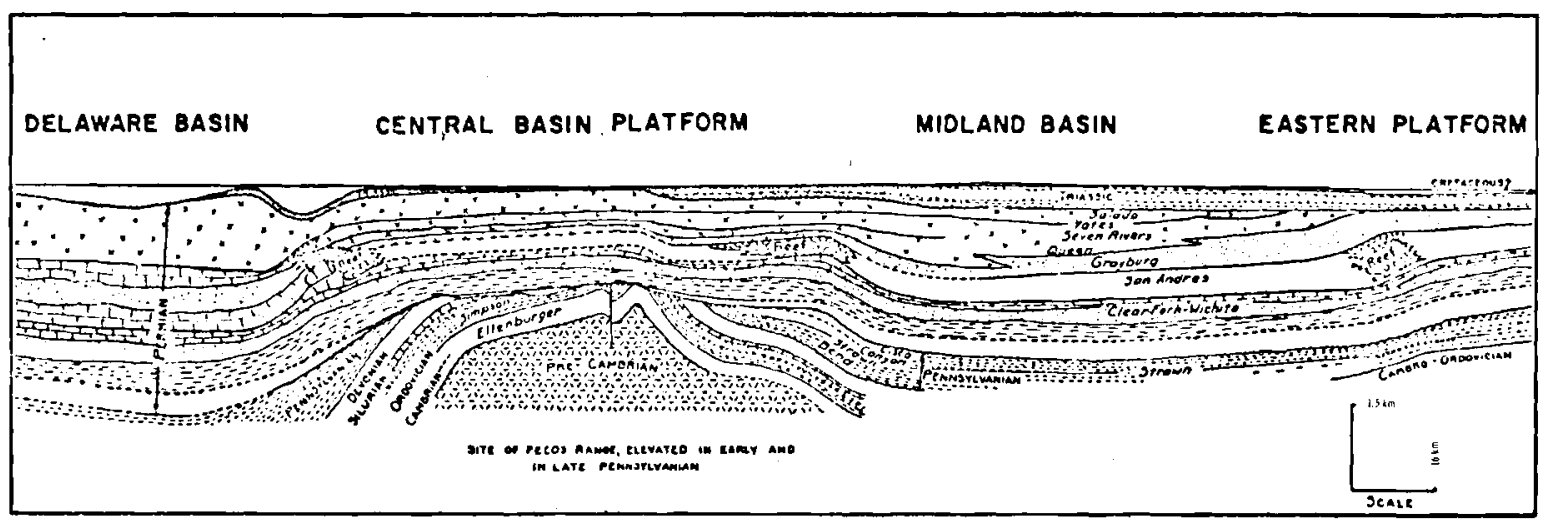

LIMESTONE SANDSTONE SHALE IGNEOUS, METAMORPHIC $\because \because$ SALT, GYPSUM

FIGURE 4.7. Geologic Section Through Delaware and Midland Basins, New Mexico and Texas (Modified from King and 0 thers, 1942)(35)

flow out of a basin either into surrounding rock, into flowing streams, or into a body of water such as a lake or an ocean. Figure 4.4 presents examples of groundwater flow under artesian conditions from areas of recharge at the land surface toward areas of discharge at the center or the margins of the basins.

Most sedimentary basins contain geologic structures such as faults and folds. All contain many lateral and vertical variations in rock types and permeability resulting in a complex pattern of groundwater flow. Geologic structures exert considerable influence on the movement of groundwater, and aquifers that are generally separated by rocks with very low permeability may be hydraulically connected along faults and fractures. A decrease in porosity and permeability at great depths may occur due to the compaction of rocks under the great weight they were exposed to during compaction of the sediments. The velocity of water movements related to basin flow systems can be greatly decreased by the occurrence of overlying rocks. (32) If pressures differ between aquifers, flow may occur through either interstices or fractures across the rocks of very low permeabilities that separate the aquifers. In many sedimentary basins the determination of the exact flow path of groundwater movement from recharge area to discharge area may not always be possible.

Several other potential factors of significance in sedimentary basins are abnormal subsurface pressures, the presence of saltwater or highly mineralized water, and the occurrence 
of thermal springs. Abnormal subsurface pressures may influence the movement of groundwater. Some basins in California and Wyoming and in the Gulf Coastal Plain have subsurface pressures that are higher than normal, probably owing to the compaction of unconsolidated sand and clay deposits. (36) Saltwater or highly mineralized water may affect the movement of groundwater. The aquifers in the Atlantic and Gulf Coastal Plains were filled with saltwater when the sands were deposited under the sea, but now the aquifers have been flushed by freshwater to great depths of from 300 to 1800 meters. (37) In other basins, some deep water is highly mineralized, although shallow water is fresh.

Hot or warm thermal springs (Figure 4.8) that originate at great depths and rise along deep faults or fissures indicate an upward movement of water aided by artesian pressure and hydrothermal activity or both. Nearly all thermal springs are associated with volcanic rocks, possibly indicating that unpredictable upward movement of groundwater may occur in basins that contain hot springs.

Suitability for Disposal. Sedimentary basins represent a significant part of conterminous United States; however, most sedimentary rocks, excluding shale, commonly can have significant porosities and permeabilities to depths as great as 6000 meters. This fact and the common occurrence of important aquifers and (or) oil-and gas-producing strata above, below, and within shale sequences could make the basins generally unsuitable for most wastedisposal concepts except for disposal in $5 a 1 t$.

Because shale has very low permeability and high ion-exchange capacity, it has been used as a repository for low-level waste at the 0ak Ridge National Laboratory in Tennesssee. Partly as a result of this usage, consideration has been given to using shale as repositories for high-level waste. Shale sequences throughout the United States recently have been generally evaluated for radioactive waste disposal by Merewether, Sharps, Gill, and Cooley. (39) They conclude that, in general, the shale sequences are not suitable for waste disposal but that detailed investigations may disclose some strata that are acceptable.

In most basins where thick shale sequences occur, drill-hole data indicate that few zones exist without thin interbeds of sandstone and (or) limestone that drastically increase the overall permeability of the sequence. In some basins water moves slowly through shale because of permeable interbeds that are cut and displaced by faults and fractures. At shallow depths both water-bearing fractures and faults and permeable interbeds will probably occur in the vicinity of any potential wastedisposal site. It would be difficult, therefore, to assure that waste can be effectively contained for very long time periods if the waste is initially emplaced in shale below existing water tables. There is a possibility, however, that shale can 


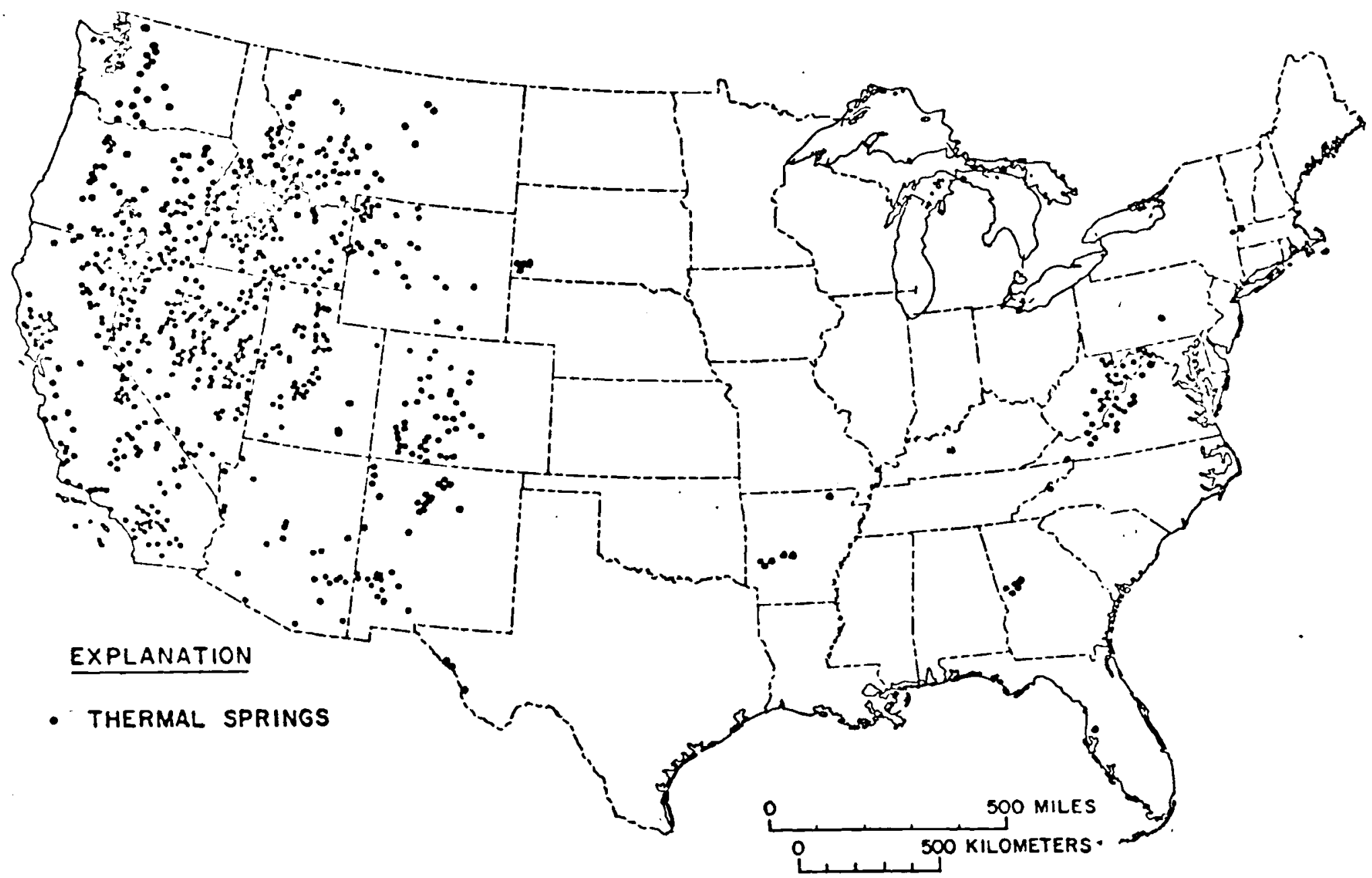

FIGURE 4.8. Thermal Springs in the United States
(Modified from Waring, 1965)(38)

$\sum_{2}^{\infty}$
$\frac{1}{1}$
0
8
0 
be used for shallow-depth mined cavities above the water table provided the water table is deep enough.

At depths below 2000 meters detailed investigations in some basins may define thick shale sequences in which fluid flow can be predicted to be extremely slow. Therefore, this geologic environment could be considered as possibly suitable for the matrix hole and exploded cavity concepts. The basic premise is that at depths below about 2000 meters fractures in shale will probably be tight and porosities and permeabilities of thin interbeds will be diminished.

At these depths, however, the structural instability of some shale may prove to be a difficult problem during operational phases.

Geologically and hydrologically, salt may be one of the more suitable media for waste disposal in sedimentary basins (Figure 4.9). Studies so far indicate that salt (bedded or in stable domes) can be potentially suitable for shallow-depth mined cavities and shallow-or moderatedepth explosive cavities. Salt could also be potentially suitable for the matrix of drill holes, but largediameter drill holes may be unstable and close rapidly in salt at depths below 1000 to 1500 meters.

\subsection{Igneous and Metamorphic}

Systems. Crystalline igneous and metamorphic rocks occur in several large areas in the Eastern, Western, and Northern United States and also in several small areas in the continental interior. Because these rocks have very low porosities and permeabilities (where they are not faulted) especially in the subsurface below depths of about 1000 meters, they are potentially suitable for waste disposal. The principal areas are shown by the stippled pattern on Figure 4.10. The granite and ultramafic bodies and the gneissic rocks seem to comprise the most suitable igneous and metamorphic media for waste disposal. At the Atomic Energy Commis sion's Savannah River plant, near the boundary of the piedmont and the coastal plain, hydraulic tests were run in several holes completed in crystalline rock at relatively shallow depths (to 550 meters). (40) A11 the rock contained fractures, but permeabilities were low, averaging 0.01 liters per day per square meter; this was estimated from transmissivities ranging between 0.025 and 2.5 liters per day per meter. At deeper levels the rocks probably would have even lower permeabilities.

Groundwater. Igneous and metamorphic rocks of the eastern metamorphic belt yield abundant water to wells that average less than 140 meters in depth. (41) Fractures in the rock carry the water, and these logically may be tight and possibly healed in the deeper subsurface. Where sheet mica is mined successfully in the Piedmont at shallow depths, the mines are virtually dry.

Precambrian shield rocks yield little water and usually are explored only for small domestic water supplies. Near the surface, fractures and clayey weathered zones in the igneous and metamorphic rocks yield small supplies of water. (37) Mines in the shield rocks at Sudbury, ontario, are extremely dry in levels 


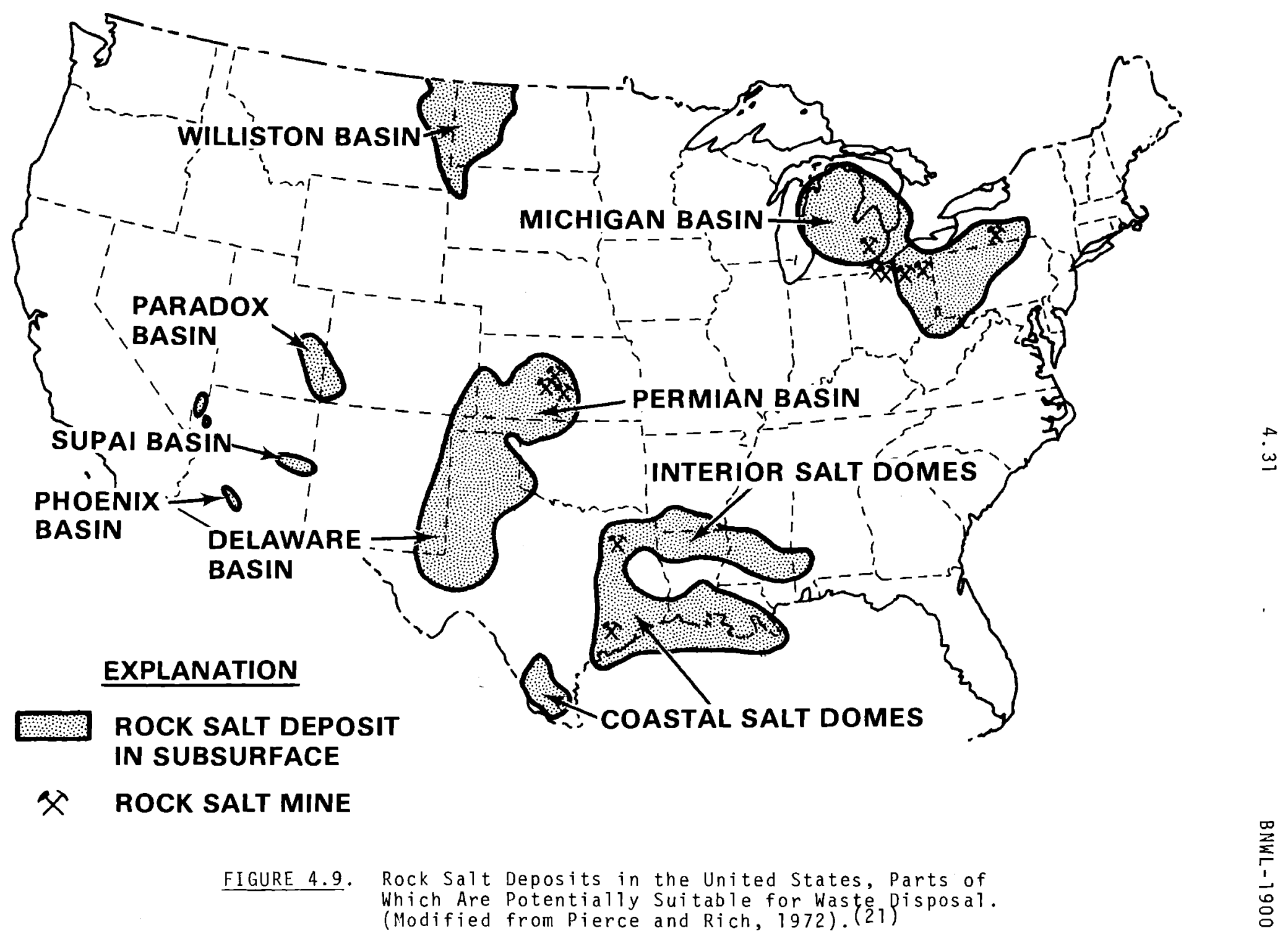




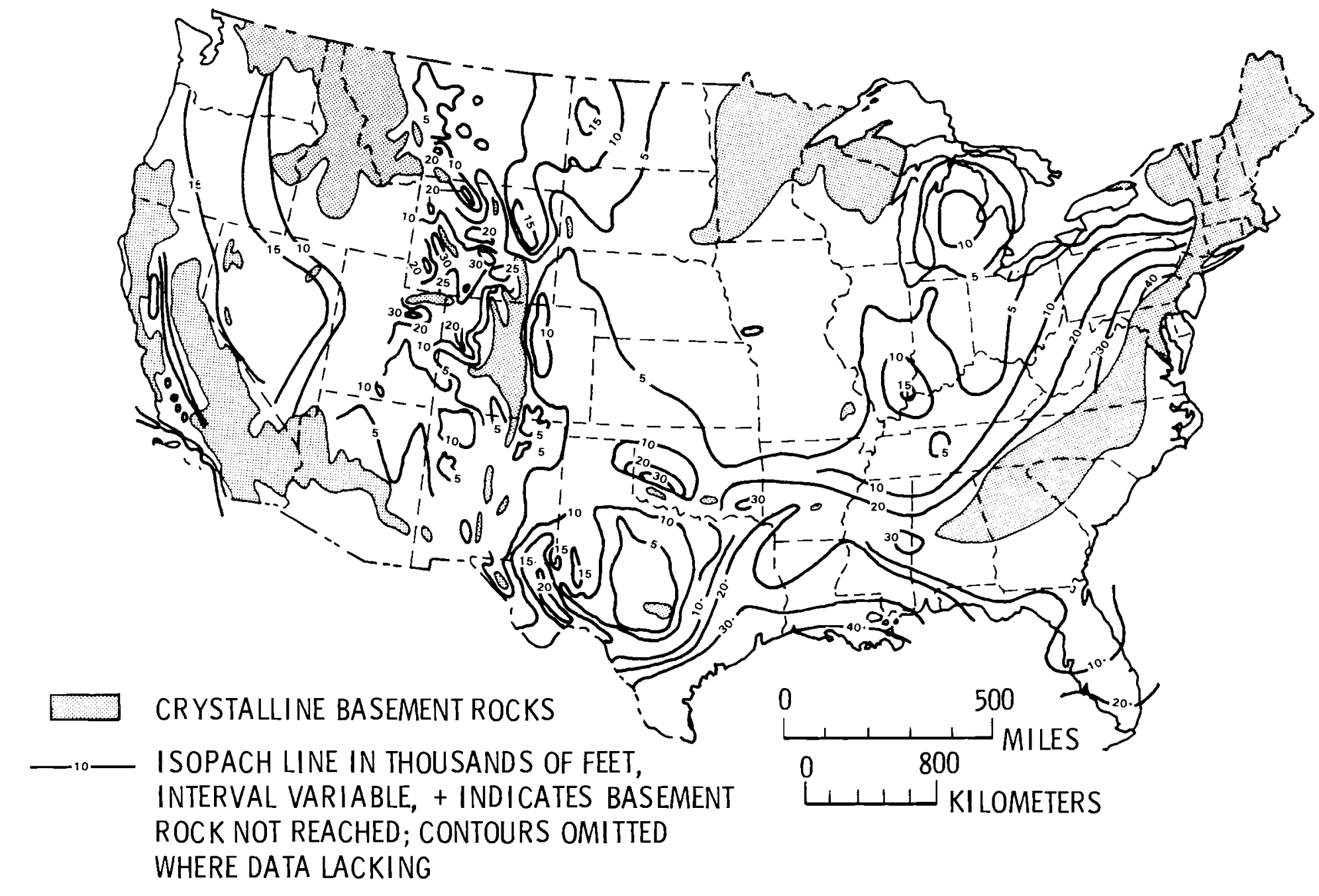


below a hundred meters of the surface. Mines of the Michigan Copper Company, which have hundreds of kilometers of workings to depths of 1500 meters, encounter such smal1 amounts of water that no pumps are required.

The ability of a metamorphic rock to prevent the escape of liquids within a thousand meters of the surface and the ability of another rock to readily transmit liquids are illustrated by the probable movement of water below the surface at Warm Springs, Georgia (Figure 4.11). Water percolating downward through permeable basal beds of a quartzite underlain by a gneiss with very low permeability encounters a marked fault that offsets the quartzite. The fault acts as a barrier to the movement of the water, causing it to return to the surface through permeable beds in the uppermost part of the quartzite. These beds are overlain by a schist having relatively low permeability, which prevents the escape of the water before it reaches the surface at Warm Springs. The fact that the fault acts as a barrier rather than as a conduit is an example of an old fault encountered at depth being completely healed and not necessarily detrimental.

Suitability for Disposal. It is concluded that metamorphic and intrusive igneous rocks are suitable or possibly suitable for waste disposal in the shield area, the eastern metamorphic belt, and small areas in the continental interior. This conclusion is based on the inference that if faults are avoided these rocks will have very low permeabilities a few thousand or a few hundred meters below the surface. The inference stems from field observations, shallow-well data, and the knowledge that some mines in metamorphic and igneous rocks are dry at shallow depths. Data are scanty, however, and until the areas are drilled and hydraulically tested, the conclusion should be regarded as tentative.

\subsubsection{Geochemical Considera- tions}

4.0.3.4.1 Ion-Exchange Reactions. Nearly all rocks exhibit the capability of sorbing cations (ion-exchange) such as cesium and strontium from solution. The sorbing capability is especially high in clay minerals. The gross effect of sorption is reduction of the velocity of cation travel to less than the velocity of the transporting water. The degree of retardation of ionic flow depends on the chemical nature of the species, the concentrations of competing species in solution, and the extent and nature of the host rock.

A side effect of sorption is that exchangeable ions are released from the host rock into solution. For instance, sorption of cesium or strontium ions by clay releases sodium or potassium ions into the water, and these released ions, together with ions originally present in the solution, can compete with waste material for available exchange sites. This is the reason that cation movement is only retarded and not stopped. Calcium and magnesium ions tend to affect significantly the retardation of 


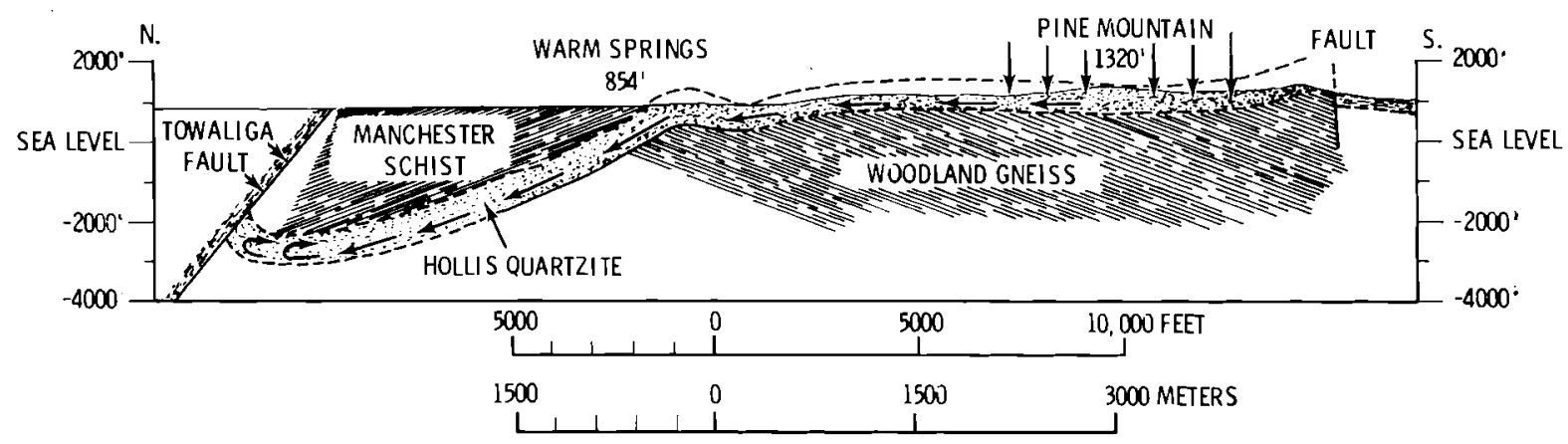

FIGURE 4.11. Cross Section Through Pine Mountain and Warm Springs, Georgia, Showing Geologic Structure and (by Arrows) Probable Course of the Water That Enters Hollis Quartzite as Rain on Pine Mountain and Is Discharged at Warm Springs. (Modified from Hewett and Crickmay, 1937). (42)

strontium ions, and sodium and potassium ions affect strontium retardation very little except at high concentrations. For example, disposal of strontium in dolomite would result in releasing calcium and magnesium ions to solution which then would compete with the remaining strontium ions, and the travel of strontium ions woll $1 \mathrm{~d}$ not be retarded as much as through some other type of host rock.

The degree of retardation also depends on physical parameters such as bulk density and effective porosity of the host rock. Sorption is a phenomenon displayed by all solid substrates. The degree to which these substrates may accommodate sorbants partly depends on the nature of, but more significantly, on the total surface area of the substrate. The larger the surface area per unit mass for a given substrate the greater will be its sorption capacity. If the substrate particles are small enough (e.g., colloidal), they may move with the groundwater together with their sorbed materials, effectively increasing the transport velocity of the sorbents. Should these colloidal materials have a residual electrical charge, however, they in turn may be sorbed on bulkier substrates, thereby decreasing the effective sorbent velocities.

The preceding dicussion has been focused on sorption of cations; however, sorption may or may not have as much effect on movement of anions such as bromides, iodides, and sulfides. Very little study, beyond laboratory conditions, has been conducted on anionic solutions. Most of these studies have been made with iodide. The movement of iodide ions has been measured at significantly higher rates than those of most cations under similar conditions; therefore, it is probable that the mechanisms that control retardation of cations do not readily apply to retardation of anions. 
Another group which must be examined is the potential nonionic species of waste constituents. Tritiated water is in the nonionic group. The effect of host rocks on the movement of tritium, as tritiated water, has been studied with varying degrees of success. Although it is not well defined, it is an accepted fact that there is some measurable retardation of tritium; however, the leading edge of a pulse of tritiated water may move at about the same rate as the water.

A distribution coefficient $\left(K_{d}\right)$ is a measure of retardation potential of a host rock. Figure 4.12 illustrates ranges of distribution coefficients for some rock types measured under laboratory conditions. However, the rock samples were in "natural state"-as physically undisturbed as possible. Ideally, when selecting a geologic environment for waste disposal, the waste constituents and the host environment should be matched for favorable retardation. Movement of cations should be significantly retarded in rocks containing clay or zeolites, which exhibit large surface areas capable of ion exchange. Anionic and nonionic wastes probably should be disposed in water-insoluble forms to minimize leaching by the formation water.

\subsection{Rock-Waste Interactions} in the Presence of Water. In all geologic disposal concepts, it is most likely that the solid waste forms will eventually come into direct contact with the rocks. Such contact will result in chemical and physical interactions of the waste and the rock. These interactions will tend to be accelerated by the higher-thanambient temperatures associated with the waste. A brief review is presented of rock-waste interactions possible in the presence of water as pore water in the rocks, as underground aquifers, or as water associated with the waste.

To place glass-waste composition into rock storage with potential or actual water contact is to invite migration of ions, including the radionuclide ions. Boron and the alkalis ( $N a, K$ and presumably $C S$ ) are known to have migrated several hundreds of meters under the impetus of a thermal gradient during geologic time spans. Many crystalline phases are theoretically possible under self-heating conditions, but ion migration is just as likely a possibility in any rock type, especially if the waste was originally in aqueous solution.

To examine the ion migration process further, some data are reviewed which were obtained'in a study of metamorphic processes most closely resembling the self-heating aqueous waste. A temperature-pressure diagram of the upper crust of the earth summarizes the metamorphic processes $(44)$ in Figure 4.13. In this diagram, the metamorphic processes are considered to extend between diagenesis (processes that occur under the relatively mild thermal conditions of sedimentation and include ion exchange, compaction, pore water migration, etc.) on the one hand (left side) and the minimum temperature for melting of granite on the other. As the rock begins to melt on the other end of the scale, the rock 


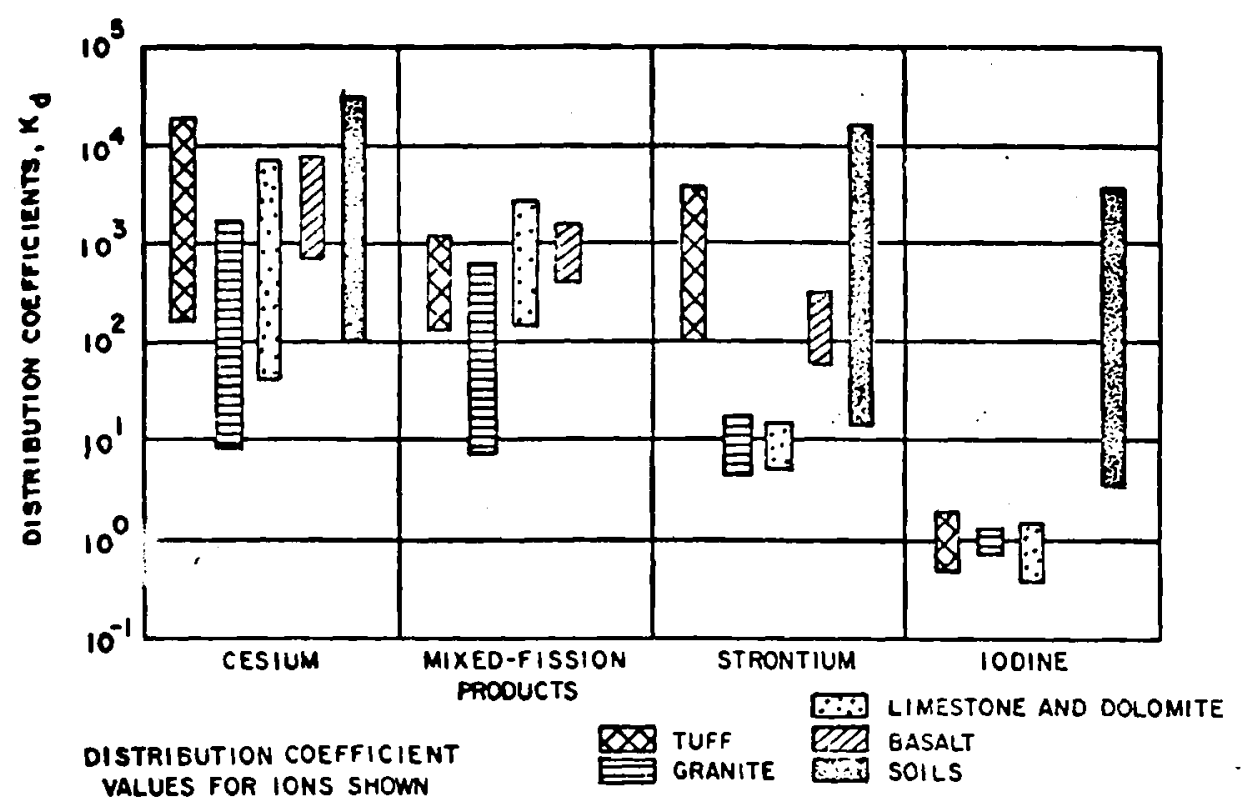

FIGURE 4.12. Ranges of Distribution Coefficients fgr Various
Rock Types (After D. B. Grove, 1970)

becomes igneous, or undistinguishable from an igneous rock. The various rock groups referred to in the diagram comprise a stable group of mineral phases characteristic of given temperature, pressure and compositional conditions.

It is seen from Figure 4.13 that the rocks or minerals change as a function of temperature and pressure. To restate, the minerals recrystallize with increased temperature and pressure to a different group of rocks that is stable under the new pressure-temperature conditions. Recrystallization rates are also greatly affected by the presence or absence of volatile components (water, $\mathrm{CO}_{2}$ and other gases). Some metamorphic rocks have apparently endured high temperatures and pressures for a span of geological time with little recrystallization. Nonetheless, other compositionally similar rocks at lower temperatures have undergone extensive recrystallization of components. This apparently contradictory behavior is explained by the presence or absence of hydrothermal solutions (warm water solutions) during the metamorphism. With water present, recrystallization is relatively rapid and extensive. These hydrothermal solutions obviously leave the rock after metamorphism. Thus, the rock can show a bulk composition that is nearly the same before and after metamorphism but possess an entirely different bulk composition during metamorphism. The rock bulk compositions before and after metamorphism can also be considerably different due to materials added or removed by the hydrothermal solutions during metamorphism. The composition of these hydrothermal aqueous solutions are of 


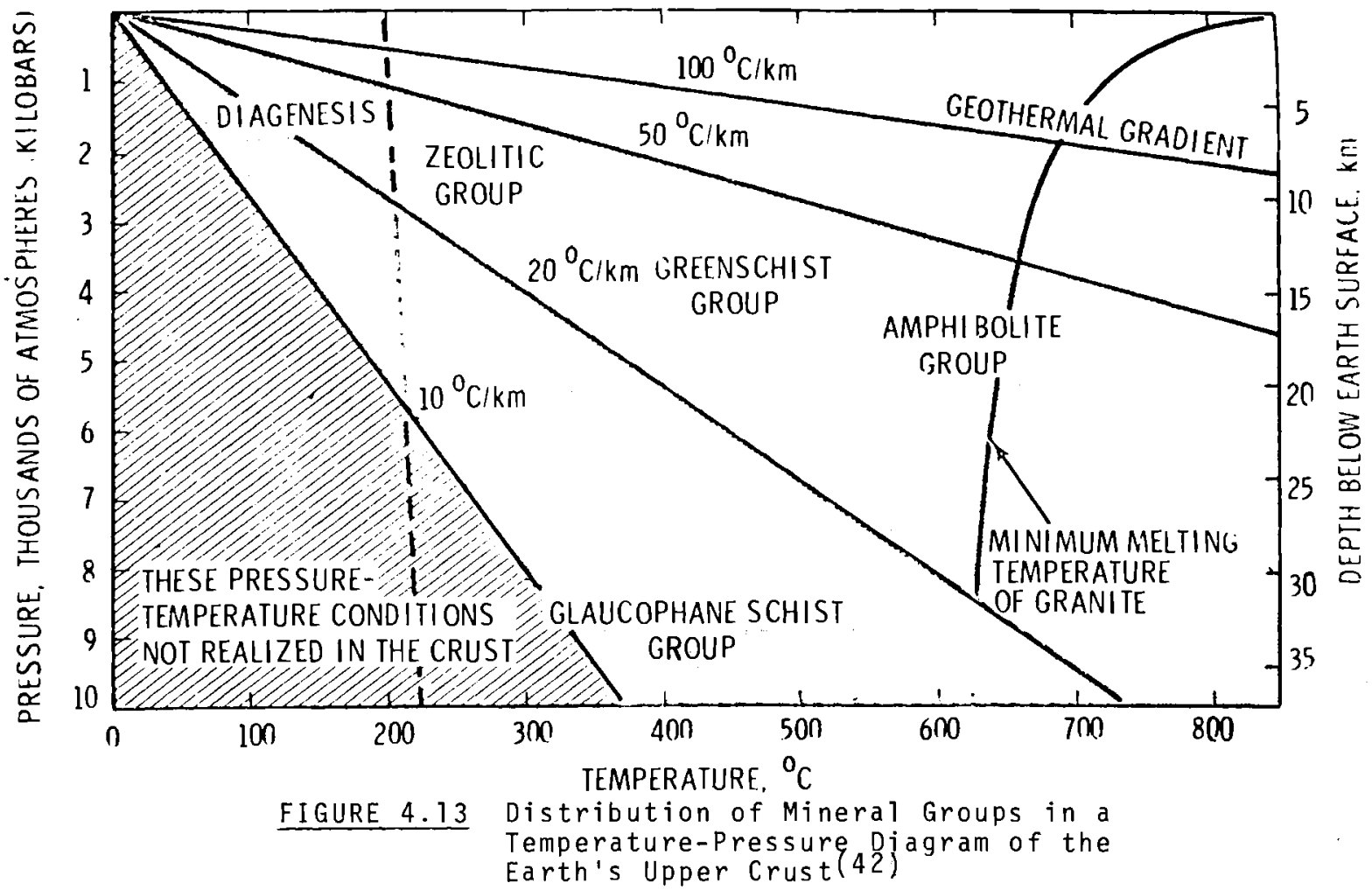

interest to us here because these compositions represent ions migrating under the impetus of a thermal driving force that may result in hydrothermal alteration.

Hydrothermal alteration literally refers to the changing of a rock through the agency of hot water. The changes may involve isochemical transformations, or attainment of a new crystal structure without a compositional change, in response to new temperature and pressure conditions. Usual1y, however, a compositional change occurs as well. The new phases formed are those stable under the new pressure, temperature and compositional conditions. There is usually an increase in altered rock porosity, which means that rock alteration is usually not a constant volume process.
Probably the most important chemical process in rock alteration is that of mineral hydrolysis. Sericitization of orthoclase feldspar in an aqueous solution is a common example of hydrolysis:

$$
\begin{aligned}
3 \mathrm{KATSi}_{3} \mathrm{O}_{8} & +2 \mathrm{H}^{+}=\mathrm{KAT}_{2} \mathrm{AlSi}_{3} \mathrm{O}_{10}(\mathrm{OH})_{2} \\
& +2 \mathrm{~K}^{+}+6 \mathrm{SiO}_{2}
\end{aligned}
$$

(orthoclase) (sericite mica)

Many of the equilibrium activity diagrams for the common mineral phases encountered in hydrothermal alteration have been determined, and they are useful for evaluating the phases stable in a given temperature and composi tional environment and how these change with a changing environment.

The process of solution and redeposition of mineral phases by a hydrothermal solution during metamorphism is called metasomatism. During metasomatism, certain elements 
are mobile and others are immobile as a function of the prevailing pressure, temperature and compositional conditions. No list of relative mobilities of the elements can be given that is valid under all system conditions. However, Korzhinsky(45) has proposed an average list of elemental mobilities after much study, from high to low mobilities: $\mathrm{H}_{2} \mathrm{O}, \mathrm{CO}_{2}, \mathrm{~S}$, $\mathrm{SO}_{3}, \mathrm{Cl}, \mathrm{K}, \mathrm{Na}, \mathrm{F}, \mathrm{Ca}, \mathrm{O}_{2}, \mathrm{Fe}, \mathrm{Mg}, \mathrm{Si}$, $\mathrm{P}, \mathrm{A} 1, \mathrm{Ti}$.

When mineral phases grow or recrystallize in a hydrothermal solution medium, growth irregularities of many kinds trap small portions of the growth solution medium in the solid crystal. (46) These fluid inclusions can be found in most metamorphic mineral rock types, thereby giving evidence for the presence of a fluid phase during metamorphic crystal growth or recrystallization. The inclusions are called fluid rather than aqueous because they sometimes contain liquid $\mathrm{CO}_{2}$ or petroleum as well as a crystalline solid phase such as pyrite $\left(\mathrm{FeS}_{2}\right)$ cubes or halite ( $\mathrm{NaCl}$ ) cubes in aqueous media. They vary in size from the usual microscopic dimensions to several centimeters in a few cases. Fluid inclusions larger than 0.1 millimeter are relatively uncommon, with the majority less than 0.01 millimeter in size. Ordinary white, metamorphic quartz $\left(\mathrm{SiO}_{2}\right)$ usually contains about $10^{9}$ fluid inclusions $/ \mathrm{cm}^{3}$. Even the white color in this quartz is due to light dispersion by the inclusions; quartz without inclusions is transparent. In any case, the fluid inclusions represent small samples of the original crystal growth solution medium, or metasomatic solution.

Examples of some analyses of metamorphic quartz fluid inclusion are given in Table 4.5 The total salt content in the aqueous inclusion fluids varied from 3850 to $291,000 \mathrm{ppm}$ $(0.38$ to $29 \mathrm{wt} \%$ ) from the more than 800 available analyses with over $100,000 \mathrm{ppm}$ average for total salt content. Twenty weight percent total salts in the aqueous solutions are common. Homogenization temperatures, or temperatures at which the aqueous fluid inclusions became a single liquid phase when more than one fluid phase (e.g., vapor and liquid) was present and completely filled the original cavity in the crystal, were determined by applying heat and assuming a pressure correction. Homogenization temperatures varied from about $100^{\circ}$ to $500^{\circ} \mathrm{C}$ for metamorphic quartz.

Although complete chemical analyses of the fluid inclusions are not available, in general they contain rather large amounts of all the alkali metals including cesium plus many of the alkaline earth metals, presumably including some strontium.

Metasomatic processes have occurred in all rock types with the exception of rock salt, which presupposes the absence of water or other volatile constituents. Placing liquid waste into rock salt formations would negate the one redeeming feature of a nearly anhydrous environment, and dispersive metasomatic 
TABLE 4.5. Some Compositions of Metamorphic Quartz Fluid Inclusion

$\mathrm{ppm} / 10,000 \mathrm{ppm} \mathrm{C1}$

\begin{tabular}{|c|c|c|c|c|c|c|c|c|c|c|}
\hline Sample & $\underline{\mathrm{Li}}$ & $\mathrm{Na}$ & $K$ & $\underline{\mathrm{Rb}}$ & $\mathrm{Cs}$ & $\mathrm{Mg}$ & $\mathrm{Ca}$ & $\mathrm{SiO}_{2}$ & $\mathrm{HCO}_{3}^{-}$ & $\underline{S O}_{4}=$ \\
\hline 1 & -- & 3500 & 1400 & -- & -- & 600 & 2000 & 9000 & 2500 & 5200 \\
\hline 2 & 60 & 8000 & 10100 & 30 & $<7$ & -- & - & -- & -- & 800 \\
\hline 3 & 100 & 8300 & 8300 & 32 & $<3.5$ & -- & -- & -- & -- & 2000 \\
\hline
\end{tabular}

1. Quartz crystals from veins in metamorphosed sediments, Dagestan, U.S.S.R. Homogenized at 105 to $200^{\circ} \mathrm{C}$.

2. Microscopic inclusions in massive, white, 3 -foot quartz pod in in chlorite schist, Antelope Island, Great Salt Lake, Utah. Homogenization estimated at $200^{\circ} \mathrm{C}$.

3. Massive quartz, Empire Gold Vein, Grass Valley, California. Homogenization at 80 to $185^{\circ} \mathrm{C}$.

processes may once again become operative. A critical evaluation of data and theories about the composition and origin of marine salt deposits was presented by Braitsch. (47) Phase studies prove that the present composition of certain salt deposits may have been formed from low-temperature metamorphism.

The effect of the geothermal gradient on metamorphic processes is another consideration in geologic waste disposal. The average geothermal gradient is about $20^{\circ} \mathrm{C} / \mathrm{ki}$ lometer, although this can range from $5^{\circ} \mathrm{C} / \mathrm{kilometer}$ to $200^{\circ} \mathrm{C} / \mathrm{kilometer}$ in the upper crust of the earth. In the latter case, it is safe to assume that the large heat flow is emanating from a radiating, magmatic heat source at greater depth. To minimize the potential for ion migration, it would generally be wise to avoid such areas of high heat flow for waste disposal.

At least some of the chemical ions of elements which have radionuclides in the waste are known to occur in metasomatic solutions that have passed through several hundred meters of nearly impermeable rock during geological time and were eventually dispersed to the environment through groundwater mixing, hot springs, etc. Care must be exercised in the placement of self-heating solidified wastes that can interact with water already present in the environment, to minimize generation of metasomatic solution and dispersion of the radionuclide ions over considerable distances during geologic time spans.

The waste should preferably be in solid form to assure that rock-waste 
interactions will include recrystallization processes that completely immobilize the fission product ions. Consideration of similar natural processes involving heat and hydrothermal solutions (metasomatism) suggest that dispersive processes are more likely for the alkali and alkaline earth metal fission product ions. In solid form, such as incorporated into a glass, the waste should be kept out of contact with aqueous solutions potentially present in a disposal environment. Hence, to minimize such waste ion migration, long-term disposal in relatively anhydrous rocks is preferred. Such rocks include salt and dry igneous rocks.

Most marine sedimentary rocks contain an aqueous pore solution that approximates seawater in composition. (48) These pore solutions can move about if the sedimentary rock has any permeability and often do so. placing a heat source such as selfheating waste in a permeable sedimentary rock containing a pore solution is conducive to dispersing this pore solution plus some of the radionuclide ions.

Thus the preferred rock types and waste disposal forms present a tradeoff of sorts. If the anhydrous condition of the disposal site can be assured over the required time span, the waste form is less critical. If water contact can be expected, the waste form becomes very critical for safe disposal.

\subsection{Molten Rock-Waste Inter-} actions. In all geologic disposal concepts considered, it is most. likely that the waste forms will eventually come into direct contact with the rocks. Such contact will result in chemical and physical interactions of the waste and the rock that will tend to be accelerated due to the higher-than-ambient temperatures associated with the waste. A brief review is presented of general rockwaste reactions which could be expected in various disposal schemes.

The reaction of a reference borosilicate glass used in the Waste Fixation Program at PNL (melt number 72-4, Table 4.6) with several rocks is considered. The rocks included a typical basalt, granite, nepheline syenite, graywacke sandstone, shale, limestone and rock salt (Tables 4.7 and 4.8). Three cases of melting of these rocks of average composition with the reference waste formulation were reviewed.

TABLE 4.6. Composition of Melt Number 72-4 Minus the FP oxides (12.8 wt\% in the original composition)

\begin{tabular}{cr} 
Constituent & Wt $\%$ \\
\hline $\mathrm{SiO}_{2}$ & 36.4 \\
$\mathrm{Al}_{2}{ }_{2}{ }_{3}$ & 7.7 \\
$\mathrm{~B}_{2} \mathrm{O}_{3}$ & 15.9 \\
$\mathrm{Fe}_{2} \mathrm{O}_{3}$ & 9.1 \\
$\mathrm{CaO}$ & 12.8 \\
$\mathrm{Na}_{2} \mathrm{O}_{3}$ & 10.6 \\
$\mathrm{U}_{3} \mathrm{O}_{8}$ & 7.4 \\
& 99.9
\end{tabular}


In the first case it was assumed that only the waste borosilicate glass itself would recrystallize upon cooling from the molten phase. Possible phases from this recrystallization include danburite $\left(\mathrm{CaB}_{2} \mathrm{Si}_{2} \mathrm{O}_{8}\right)$, reedmergnerite
(NaBSi $\left.{ }_{3}{ }_{8}\right)$, coffinite $\left(\mathrm{USiO}_{4}\right)$ or uraninite $\left(\mathrm{UO}_{2}\right)$, hematite $\left(\mathrm{Fe}_{2} \mathrm{O}_{3}\right)$ and plagioclase feldspar ( $\mathrm{Ca}, \mathrm{Na}_{2} \mathrm{Al}_{2} \mathrm{Si}_{2} \mathrm{O}_{8}$ ). The estimates of phases crystallizing from the melt are based on knowledge of similar natural systems.

TABLE 4.7. Range of Minor Constituents of Average Composition Rocks in Parts Per Million ( $R E=$ rare earths, PtGr = platinum group)

\begin{tabular}{|c|c|c|c|c|c|c|c|}
\hline & Granite & Basalt & $\begin{array}{l}\text { Nepheline } \\
\text { Syenite }\end{array}$ & $\begin{array}{l}\text { A11 } \\
\text { Igneous } \\
\text { Rocks } \\
\end{array}$ & $\begin{array}{l}\text { Sands tone } \\
\text { (Graywacke) }\end{array}$ & Shale & Limes tone \\
\hline $\mathrm{Ag}$ & 0.02 & 0.03 & 0.03 & 0.07 & 0.07 & 0.05 & 0.05 \\
\hline B & 10 & 1.6 & 10 & 10 & 35 & 100 & 20 \\
\hline $\mathrm{Ba}$ & 430 & 600 & 520 & 425 & 50 & 580 & 120 \\
\hline $\mathrm{Cd}$ & 0.12 & 0.19 & $<0.1$ & 0.2 & 0.05 & 0.3 & 0.035 \\
\hline Co & 8 & 30 & 8 & 25 & 0.3 & 19 & 0.1 \\
\hline $\mathrm{Cr}$ & 10 & $50-200$ & 4 & 100 & 35 & 90 & 11 \\
\hline Cs & 40 & $<1$ & 6 & 1 & 0.5 & 12 & 0.5 \\
\hline $\mathrm{Cu}$ & 16 & 149 & 10 & 55 & 5 & 45 & 4 \\
\hline Mo & 12 & 3 & 2 & 1.5 & 0.2 & 2.6 & 0.4 \\
\hline $\mathrm{Ni}$ & 2.4 & 65 & 2.4 & 75 & 2 & 68 & 20 \\
\hline$P$ & 870 & 2440 & $\begin{array}{l}\text { Up to major } \\
\text { constituent }\end{array}$ & 1050 & 170 & 700 & 400 \\
\hline PtGr & $<0.01$ & $<0.1$ & $<0.01$ & 0.012 & $<0.01$ & $<0.01$ & $<0.01$ \\
\hline RE & 225 & 174 & $2000-4000$ & 177 & 118 & 31 & 135 \\
\hline $\mathrm{Sb}$ & 0.2 & 0.4 & 0.1 & 0.2 & 0.05 & 1.5 & 0.2 \\
\hline $\mathrm{Sr}$ & 120 & 150 & 1200 & 375 & 20 & 300 & 610 \\
\hline $\mathrm{Te}$ & $<0.01$ & $<0.01$ & $<0.01$ & 0.001 & $<0.01$ & $<0.1$ & $<0.01$ \\
\hline U & 3.96 & 0.83 & 15 & 2.7 & 0.45 & 3.7 & 2.2 \\
\hline $\mathrm{Zn}$ & 60 & $100-130$ & 50 & 70 & 16 & 95 & 20 \\
\hline $\mathrm{Zr}$ & 460 & 140 & $1000-3000$ & 165 & 220 & 160 & 19 \\
\hline
\end{tabular}


TABLE 4.8. Composite Analyses of Several

Igneous and Sedimentary Rocks

\begin{tabular}{|c|c|c|c|c|c|c|}
\hline & Granite & Basalt & $\begin{array}{l}\text { Nephel ine } \\
\text { Syenite }\end{array}$ & $\begin{array}{l}\text { Graywacke } \\
\text { (Sands tone) }\end{array}$ & Shale & Limestone \\
\hline $\mathrm{SiO}_{2}$ & 70.18 & 49.06 & 54.63 & 64.0 & 58.10 & 5.19 \\
\hline $\mathrm{TiO}_{2}$ & 0.39 & 1.36 & 0.86 & 0.5 & 0.65 & 0.06 \\
\hline $\mathrm{Al}_{2} \mathrm{O}_{3}$ & 14.47 & 15.70 & 19.89 & 14.0 & 15.40 & 0.81 \\
\hline $\mathrm{Fe}_{2} \mathrm{O}_{3}$ & 1.57 & 5.38 & 3.37 & 1.3 & 4.02 & 0.54 \\
\hline $\mathrm{FeO}$ & 1.78 & 6.37 & 2.20 & 4.1 & 2.45 & -- \\
\hline MnO & 0.12 & 0.31 & 0.35 & 0.1 & 0.40 & 0.05 \\
\hline $\mathrm{MgO}$ & 0.88 & 6.17 & 0.87 & 2.9 & 2.44 & 7.90 \\
\hline $\mathrm{CaO}$ & 1.99 & 8.95 & 2.51 & 3.4 & 3.11 & 42.61 \\
\hline $\mathrm{Na}_{2} \mathrm{O}$ & 3.48 & 3.11 & 8.26 & 3.5 & 1.30 & 0.05 \\
\hline $\mathrm{K}_{2} \mathrm{O}$ & 4.11 & 1.52 & 5.46 & 2.1 & 3.24 & 0.33 \\
\hline $\mathrm{P}_{2} \mathrm{O}_{5}$ & 0.19 & 0.45 & 0.25 & 0.1 & 0.17 & 0.04 \\
\hline $\mathrm{H}_{2} \mathrm{O}$ & 0.84 & 1.62 & 1.35 & 2.1 & 5.00 & 0.77 \\
\hline \multirow[t]{2}{*}{$\mathrm{CO}_{2}$} & -- & -- & -- & 1.5 & 2.63 & 41.58 \\
\hline & 100.00 & 100.00 & 100.00 & 99.6 & 98.91 & 99.93 \\
\hline
\end{tabular}

In the second case, mixing and melting of equal weights of the reference rocks and waste form were considered. The resultant compositions of the mixed melts were calculated and compared to the compositions of their nearest, naturally-occurring igneous rock equivalents. The phases crystallizing from the mixed melts were assumed to be the same phases known to occur in natural igneous rocks of the same composition. For example, a mixture of equal weights of granite and the reference borosilicate glass result in a melt very close in composition to an andesitic basalt. The phases normally found in a quartz basalt include andesine $(60 \%)$, calcium-rich augite (38\%), magnetite-ilmenite $(5 \%)$ and quartz (5\%). The limestone-waste mixture was a special case. High pressures must be maintained to avoid the formation of calcium silicate (wollastonite) and $\mathrm{CO}_{2}$ from calcite $\left(\mathrm{CaCO}_{3}\right)$ and quartz $\left(\mathrm{SiO}_{2}\right)$. With a higher-than- 
TABLE 4.9. Synthetic Rocks Produced by Mixing Equal Weights of Melt No. 72-4 and Several Natural Rocks and Closest Natural Equivalents

Quartz Basalt Tephrite Theralite Shonkinite Skarn Marble

\begin{tabular}{|c|c|c|c|c|}
\hline $\mathrm{SiO}_{2}$ & 55.5 & 39.9 & 45.6 & 48.6 \\
\hline $\mathrm{TiO}_{2}$ & 0.9 & 1.5 & 1.9 & 1.0 \\
\hline $\mathrm{Al}_{2} \mathrm{O}_{3}$ & 16.8 & 13.6 & 14.3 & 12.4 \\
\hline $\mathrm{B}_{2} \mathrm{O}_{3}$ & -- & -- & - & -- \\
\hline $\mathrm{Fe}_{2} \mathrm{O}_{3}$ & 2.1 & 6.7 & 6.2 & 3.1 \\
\hline $\mathrm{Fe} 0$ & 4.9 & 6.4 & 4.0 & 5.8 \\
\hline $\mathrm{MnO}$ & 0.2 & 0.2 & 0.2 & 0.1 \\
\hline $\mathrm{MgO}$ & 6.3 & 10.5 & 6.1 & 8.1 \\
\hline $\mathrm{CaO}$ & 7.9 & 12.4 & 9.5 & 10.4 \\
\hline $\mathrm{Na}_{2} \mathrm{O}$ & 3.3 & 3.9 & 5.1 & 2.7 \\
\hline $\mathrm{K}_{2} 0$ & 1.4 & 1.9 & 3.7 & 5.2 \\
\hline $\mathrm{P}_{2} \mathrm{O}_{5}$ & 0.2 & 0.9 & 0.7 & 1.1 \\
\hline$U_{3} 0_{8}$ & -- & -- & -- & -- \\
\hline \multirow[t]{2}{*}{$\mathrm{H}_{2} \mathrm{O}$} & 0.6 & 2.2 & 2.6 & 1.5 \\
\hline & 100.1 & 100.1 & 99.9 & 100.0 \\
\hline
\end{tabular}

normal content of boron, several phases rich in boron may crystallize from such a melt including tourmaline and axinite.

The third case was concerned with melting the waste and a large volume of rock to yield a waste-rock composition that was essentially that of the original rock. Melting the graywacke sandstone, for example, results in a granodiorite, and a shale in a diorite composition. The major mineral phases present and their natural equivalents are 1 isted in Tables 4.9 and 4.10. Uranium, for example, is known to enter the zircon structure $\left(\mathrm{ZrSiO}_{4}\right)$ in amounts up to one wt\% uranium. The dark minerals, pyroxenes and amphiboles, contain the bulk of the rare earths. An exception is the concentration of divalent europium in the calcium-bearing feldspars. Strontium accompanies calcium in the feldspars, and to a lesser degree, potassium in the potash-bearing feldspars. Barium is found predominately in the 
TABLE 4.10. Mineral Phases Present in the Natural Equivalents of the Synthetic Waste-Rock Mixtures of Table 4.9

Quartz

Basalt

Andesine

Ca-rich augite

Ilmenite

Magnetite

Quartz

\section{Theralite}

Labradorite
Nephel ine
Orthoclase
Sodal ite
Augite
Biotite
Magnetite

Vol. \%
60
30
5
5

Tephrite

Labradorite Nepheline

Analcite $\}$

Pyroxene
Vol. \%

50

40

10

Shonkinite

Na-sanadine $\quad 50$

Nepheline

Sodalite

Analcite

Augite

Biotite
10

35 plagioclase feldspars, and cesium and rubidium in the potash feldspars (orthoclase and microcline). Molybdenum, zinc, silver, technetium and the platinum group metals prefer a sulfur-rich environment and are not found in the main-stage, silicate minerals.

Tentative conclusions indicate that many of the radioactive elements would be included in the crystal lattices of the relatively insoluble silicate minerals. Exceptions, which tend to prefer a sulfur-rich environment, include molybdenum, zinc, silver, technetium and the platinum group metals. For these waste constituents, some consideration should be given to providing a sulfur-rich addition to the waste glass to prevent diffusion and dispersion of these elements during glass devitrification.

\subsubsection{Physiographic} Considerations Certain parts of the United States such as the Rocky Mountains and the Sierra Nevada Mountains could be classified unsuitable for waste disposal on the basis of rugged terrain. Although from both the engineering and the economic aspects, the terrain does not present insurmountable problems to waste disposal, other sites will probably be available in terrains that are at least equally suitable. 


\subsection{Erosion and Denudation}

Effects. Erosion is clearly the main process going on today on the earth's surface. (49) This process is of obvious concern in planning for waste disposal. The waste should be placed in locations where it will not be exhumed by erosional processes. Additionally, to provide for ease of monitoring and, possibly, site marking, locations are preferred which will not be covered significantly by the ensuing erosion products. The basic underlying cause of erosion is that all materials tend to move downhill. This tendency is shown by landslides, gullies on hillsides, accumulations of rocks (talus) at the foot of cliffs and ridges, and similar examples. Agents of erosion are (1) rivers and streams, which are the most important agents; (2) landslides and other mass movements; (3) rain, which erodes by impact and by flowing over surfaces; (4) glaciers, which erode by grinding and plucking; (5) frost action, which loosens blocks of rock and gradually causes rock to disintegrate; (6) wind, which erodes by deflation and sand blasting; (7) wave action on shorelines; and (8) chemical weathering. The overall effect of erosion is eventually to reduce irregular topography to a level plain.

The rate of erosion of the continents is determined approximately by measuring the amount of material carried by rivers. The overall average rate of erosion in the United States, determined in this way, is about 60 meters per million years. The lowest overall rate of erosion is about 40 meters per million years in the basin of the Columbia River, and the largest is about 165 meters per million years in the basin of the Colorado River. The rates of erosion vary according to specific topographic location, rock hardness, rainfall, evaporation rates, type of vegetation, and other factors The rates are sufficiently slow so that in most areas they do not constitute serious problems for waste disposal, but each site will have to be carefully evaluated.

River Erosion. Common sense dictates that a waste disposal site should not be located in the vicinity of a river or large stream.

Examples of rapid erosion in and adjacent to streams are plentiful throughout the world, especially in semiarid and arid climates (Figure 4.14) and also in some humid regions where man's farming and industrial activities have removed forest or other natural cover. In many areas it is not possible to predict erosion rates adjacent to a large stream with any degree of accuracy. This is because catastrophic flooding and rapid erosion may occur only a few times each century or may be initiated by a completely unpredictable climatic change. Such catastrophic flooding may cause a drastic change in the course of a stream or even the complete abandonment of one stream channel in favor of another. Rivers erode by several processes, and rapid downcutting can suddenly take place for a variety of reasons: for example, when a stream bed deepens itself and suddenly gains access to a soluble stratum. Relatively docile streams or those that seem to be completely controlled by 
A.

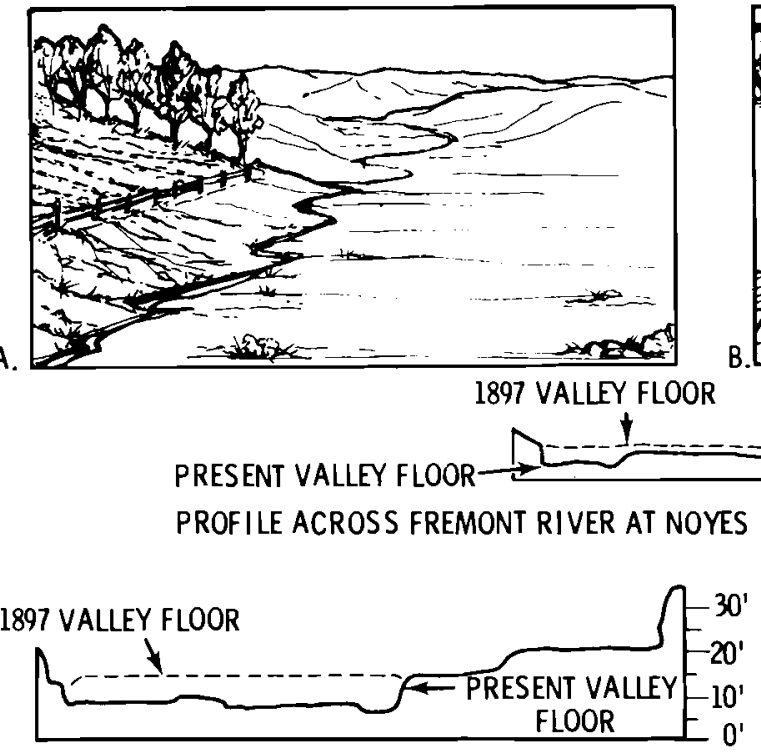

PROFILE ACROSS FREMONT RIVER AT CUTLER BEHUMIN CABIN

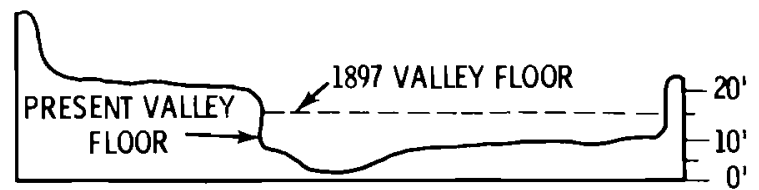

PROFILE ACROSS FREMONT RIVER AT MORT BEHUMIN FARM

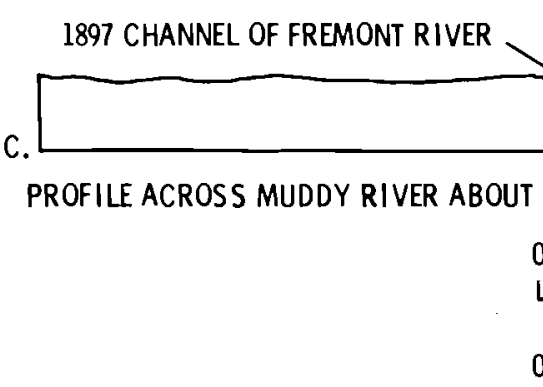

0

0

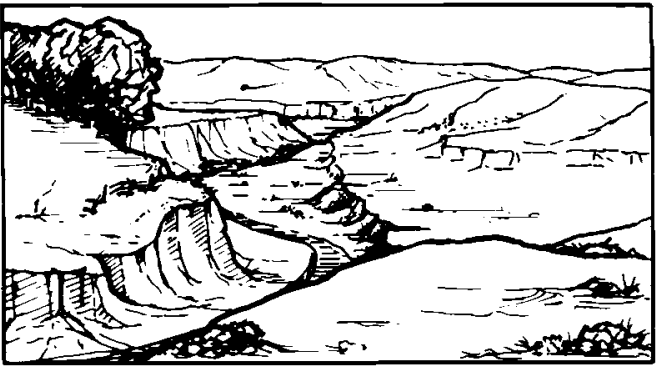

$10^{\prime}$

$0^{\prime}$

CABIN, 1-1/2 MILES BELOW ALDRICH

CAINEVILLE IN 1897

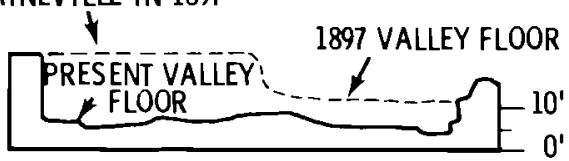

PROFILE ACROSS FREMONT RIVER AT CAINEVILLE, SOUTH OF MAIN STREET INTERSECTION

PRESENT VALLEY 1897 VALLEY FLOOR

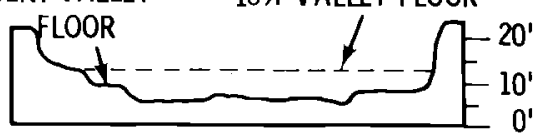

PROFILE ACROSS FREMONT RIVER AT BLUEVALLEY I MILE WEST OF TOWN WASH

1897 VALLEY FLOOR OF MUDDY RIVER

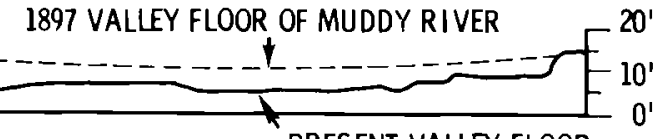

PRESENT VALLFY FLOOR

1000 FEET

250 METERS

FIGURE 4.14. Examples of River Erosion in Henry Mountains Region, Utah, since 1897. Climate change is the probable reason for this erosion. Parts $A$ and B show Pleasant Creek at Notom. The part $\dot{B}$ (present day) is 20 feet deep. Part $C$ shows cross sections of Fremont River. (Modified from Hunt and others, 1953). (49) 
man may become unmanageable as a result of climatic change or earthquake activity. When a disposal site is considered in an area where man has built $\operatorname{dam}(\mathrm{s})$, it must be kept in mind (1) that the life expectancy of these structures, either because of deterioration of the structure itself or because of the complete silting-up of the holding area, is commonly no more than a few hundred years and (2) that the dams may in some areas be vulnerable to rupture by unexpectedly large earthquakes.

Landslides Landslides are of concern to waste disposal planning in areas of moderate and rugged topographic relief. Areas to be avoided include: 1) slopes that may slide or creep, 2) areas that may be covered or exposed by a slide, 3 ) areas that may be flooded by damming of a river, 4) areas that may be affected by a sea wave resulting from land sliding beneath the sea.

Landslides may be triggered in many ways. According to Foster (50) the most common are (1) undercutting of a slope, (2) overloading of the slope so that it cannot support its new weight and, hence, must flow or slide, (3) vibrations from earthquakes or explosions that break the bond holding the slope in place, and (4) additional water which lessens the cohesion of the material.

Erosional Processes in Arid Regions. The arid and semiarid parts of the United States are affected by erosional processes that differ significantly from those in humid regions. In a particular spot rain may fall only once in many years, but when it does it commonly is a cloud- burst. The cloudburst causes flash floods that may erode large areas upslope and bury downslope areas under tons of material. These floods do not necessarily occur along well established stream channels but may occur anywhere adjacent to mountainous areas.

A feature of drainage in desert areas that is especially significant to waste disposal is that in an area of interior drainage, a basin will eventually fill to a level that will allow the ephemeral streams to flow over the lowest divide into an adjoining basin. Soon the divide is eroded and the first basin will be rapidly dissected because of the lowered base level. (50)

Wind erosion is a significant erosional process in desert regions but, except for the possibility of covering a disposal site under dune sand, is of little concern to waste disposal investigations.

A type of erosion of major concern in arid and semiarid climates is the retreating escarpment or cliff. Cliffs, for example, at the edges of mesas may retreat at rapid rates with little or no loss of height.

Schumm (51) reported average denudation rates for arid and semi-arid terrain of 100 to 200 meters per million years, and Melton $(52)$ reported slope retreat rates of 60 to 200 meters per million years.

Glaciation. Glaciers are extremely important agents of erosion. They erode by plucking large blocks of bedrock and by abrasion. They deepen and widen valleys previously formed by streams and give rise to 
valleys with a "U" shape. Where tremendous thicknesses of ice occur, valleys are deepened to great depths; an example is the fiords of Norway. Glaciers also deposit large volumes of material called drift. Drift consists of material deposited in front of, on the sides, and beneath a moving active glacier and deposits that are carried by the glacier and remain after the glacier is melted.

4.0.3.6 Seismologic Considerations

Most of the major earthquakes of the world occur in the belts along the boundaries between the global tectonic plates, One such boundary is that between the Pacific and North American plates along the west coast of the United States (Figure 4.3). The great number of damaging earthquakes that have occurred in California and western Nevada have been attributed to tectonic activity along this belt. Most fault movements in this zone in California are horizontal or strike-slip, rather than vertical or up-down. The most notable fault zone with horizontal movement is the San Andreas fault. Movement along the San Andreas fault system and other major fault systems in the Western United States is sporadic rather than constant because of friction and interlocking of the fault blocks.

Earthquake activity farther east than western Nevada or the Idaho batholith is probably unrelated to the active zone at the boundary between the Pacific and North American plates. This activity includes the earthquakes of the New Madrid, Mis- souri, area (1811-1812) and Charleston, South Carolina (1886), which were both major damaging earthquakes. Intraplate tectonism and magmatism have been demonstrated in oceanic plates; earthquakes and igneous activity that occur within the North American plate show that intraplate tectonism and magmatism occur in the continental plates as well, though the mechanism for their origin is unknown. (53)

Earthquakes are described in terms of both magnitude and intensity. Magnitude is expressed by a logarithmic scale based on the amplitude of instrumentally recorded seismic waves. Several scales in common use, depending on the type of seismic waves used are:

(1) The Richter or local magnitude scale based on recordings of short-period surface waves recorded at distances of less than $600 \mathrm{kilome-}$ ters.

(2) The surface-wave magnitude (Ms) scale based on the amplitudes of surface waves with periods near 20 seconds that are recorded at distances greater than about 2,000 kilometers.

(3) The body-wave magnitude $\left(m_{b}\right)$ scale based on amplitude/period ratios and corrections for distance and focal depth for waves recorded at distances greater than about $2,000 \mathrm{kilometers.}$

All of the scales result in numbers that are independent of the distances of the recording stations from the earthquake. (54)

In contrast, intensity is a number which expresses various effects of an earthquake at a particular location 
and thus depends, among other things: on the distance of the location from the earthquake; the magnitude of the earthquake (an indication of the energy released at the earthquake focus); the duration of the quake; and, most significantly, local geology. The intensity scale in use in the United States is the Modified Mercalli Intensity Scale of 1931 (M.M.). Assignment of an intensity value to a particular location is based on the degree of damage and various subjective criteria. (See Appendix 4.D.)

Richter magnitudes of six and greater have been recorded for earthquakes since around 1900, but records for smaller earthquakes are less complete. (31) Modified Mercalli intensities, however, have been assigned by the U.S. Coast and Geodetic Survey and other investigators to nearly all significant earthquakes known to have occurred in the United States. The historical record of seismicity in the country, therefore, does provide some guidelines to the relative seismicity of various regions. (31)

Figure 4.15 shows the locations of damaging earthquakes (intensity VII and greater) known to have occurred in the United States from historical times through 1970. Some of the strongest of these earthquakes are 1 isted in Appendix 4.E.

The relative strain release throughout the United States has also been used as an index of current tectonic activity. (31) strain release is proportional to the square root of the energy released; the energy released is determined from the magnitude of the earthquake. Using this index, Algermissen (31) has divided the conterminous United States into four areas having different rates of strain release, on the basis of data compiled from earthquakes between 1900 and 1965. The areas and number of earthquakes of equivalent magnitude four during this period are 1isted in Table 4.11. The data in the first column of Table 4.11 show that the strain release in the Pacific West during the 66-year period was approximately six times greater than in the Rocky Mountain area, 86 times greater than in the Central Plains, and 16 times greater than in the Eastern United States. Data of the second column show that the strain release in the Pacific West was respectively 5,34 , and 12 times greater than in the other areas. From the standpoint of strain release, the Pacific West is most active and the Central Plains the least active. Recurrences of earthquakes, as summarized in Tables 4.12 and 4.13 , also indicate this.

Although the Eastern United States is an area of relatively low seismicity at present, it is also characterized by low attenuation of seismic waves. According to Nuttij $(56)$ the low attenuation can result in a 100-fold increase in the total damage over the amount that would be expected in California for an earthquake of the same surface-wave magnitude. Unusual attenuation properties of Eastern United States seem to be as much responsible for the large area affected by the charleston and New Madrid earthquakes as the magnitudes of the quakes. 


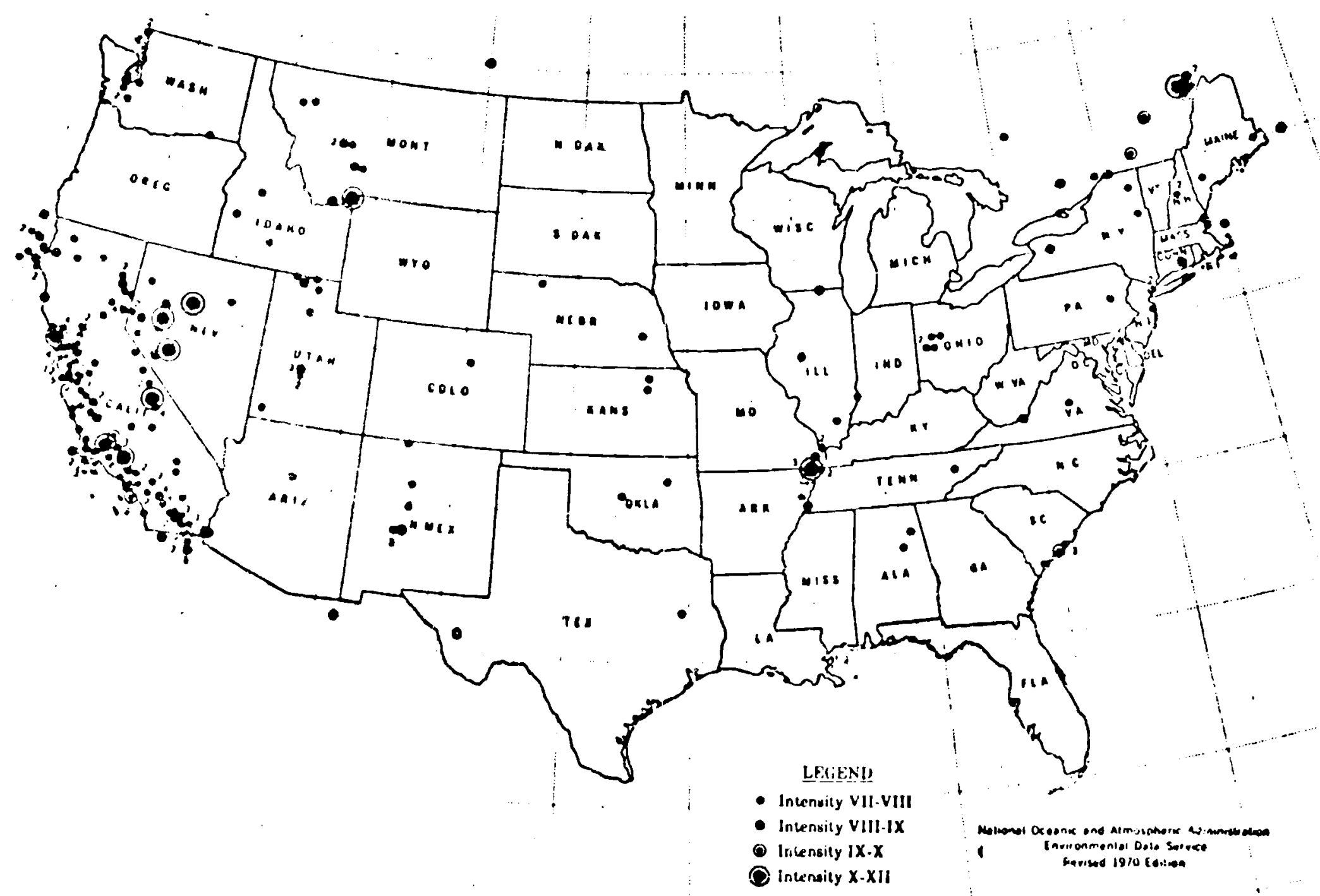

FIGURE 4.15. Damaging Earthquakes in the United States

from Earliest History Through 1970

(Modified from Coffman and von Hake, 1972)(55) 
TABLE 4.11. Strain Release Index for Four

Areas of the United States

No. Equiv. Mag 4 Earthquakes $/ 1000 \mathrm{~km}^{2}$

Area

Pacific West west of long $114^{\circ} \mathrm{W}$.

Rocky Mountainslong $106^{\circ}-114^{\circ} \mathrm{W}$.

Central Plainslong $92^{\circ}-106^{\circ} \mathrm{W}$.

Eastern U.S.east of long $92^{\circ} \mathrm{W}$.
12.

2.0

0.14

0.74
No. Equiv. Mag 4 Earthquakes $/ 1000 \mathrm{~km}^{2}$ 66 Years (b)
13.

2.6

0.38

1.1

a. Total equivalent number of magnitude 4 earthquakes in each area divided by total area.

b. Only those parts of each area considered in which more than 0.25 equivalent magnitude 4 earthquakes occurred.

TABLE 4.12. Recurrence of Earthquakes in Conterminous United States per 100 ears for Modified Mercalli Intensities $V$ to VIII

Modified from Algermissen, 1969, Table 1(31)

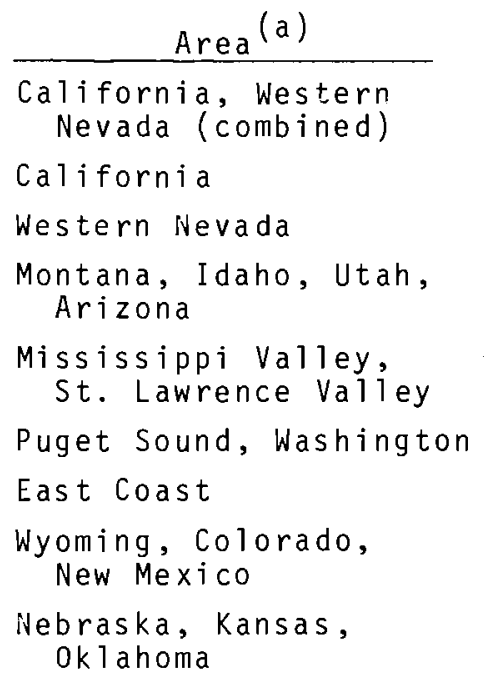

2,1

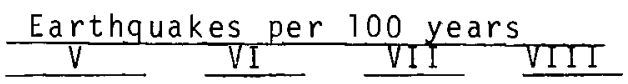

2,293

$646 \quad 182$

51.3

1,660

$479 \quad 138$

39.8

1,510

417

115

31.6

$$
407
$$

112

30.9

8.5

162

51.3

16.2

5.1

$\begin{array}{lll}53.7 & 12.9 & 3.1\end{array}$

$\begin{array}{lll}34.7 & 9.1 & 2.4\end{array}$

132

182

38.0

7.9

1.7

$\begin{array}{rrrc}34.7 & 11.2 & 3.6 & 1.2 \\ 22.4 & 6.3 & 1.8 & (0.5)\end{array}$

a. Areas arranged in order of decreasing number of modified Mercalli intensity VII earthquakes. 
TABLE 4.13. Recurrence of Earthquakes in Conterminous United States per 100 Years per

$100,000 \mathrm{~km}^{2}$, Intensities $V$ to VIII

Modified from Algermissen, 1969, Table ${ }_{2}(31)$

\begin{abstract}
Area $(a)$
California, Western Nevada (combined)

Montana, Idaho, Utah, Arizone

Puget Sound, Washington

Mississippi Valley, St. Lawrence Valley

Nebraska, Kansas, Oklahoma

Wyoming, Colorado, New Mexico

Oklahoma, North Texas

East coast
\end{abstract}

\begin{abstract}
Approximate Seismic
\end{abstract} Risk Zone

$\begin{array}{lllll}3,2 & 300 & 84.6 & 23.8 & 6.72 \\ 3,2 & 64.4 & 17.7 & 4.89 & 1.35 \\ 3,2 & 68.0 & 16.3 & 3.92 & 0.94\end{array}$

$3,2,1$

24.2

7.65

2.42

0.76

2,1

13.0

4.20

1.35

0.45

$3,2,1$

32.8

6.85

1.42

0.31

2,1

13.3

3.73

1.07

0.30

$3,2,1$

3.39

0.88

0.23

a. Areas arranged in order of decreasing number of modified Mercalli intensity VII earthquakes.

b. The recurrences of Table 4.12 have been divided by the area of each region.

It is interesting to note that the relative amounts of strain release in the four areas of conterminous United States correspond, to some degree, with the distribution of principal horizontal and vertical faults (Figure 4.16). The Pacific West, which has currently active horizontal and associated vertical faults, had the greatest rate of strain release between 1900 and 1965 . The Rocky Mountains, which have had relatively less fault movement during historical time, had considerably greater rates than the Eastern United States, in which older, inactive faults, such as the Triassic graben boundary faults, occur. The area east of 1 ong $92^{\circ} \mathrm{W}$. appears to be seismically more active, based on strain release rates, than the Central plains region, the greater part of which has deeply buried vertical faults, long since inactive, as indicated by younger undisturbed sedimentary rocks near the surface.

The distribution of damaging earthquakes (Figure 4.15) a 1 so corresponds in some degree to the four areas and the distribution of horizontal and vertical faults (Figure 4.16). The seismic activity in the Mississippi Valley, for instance, may be associated with the vertical faults in the region. Apparently little is known about the origin of damaging 


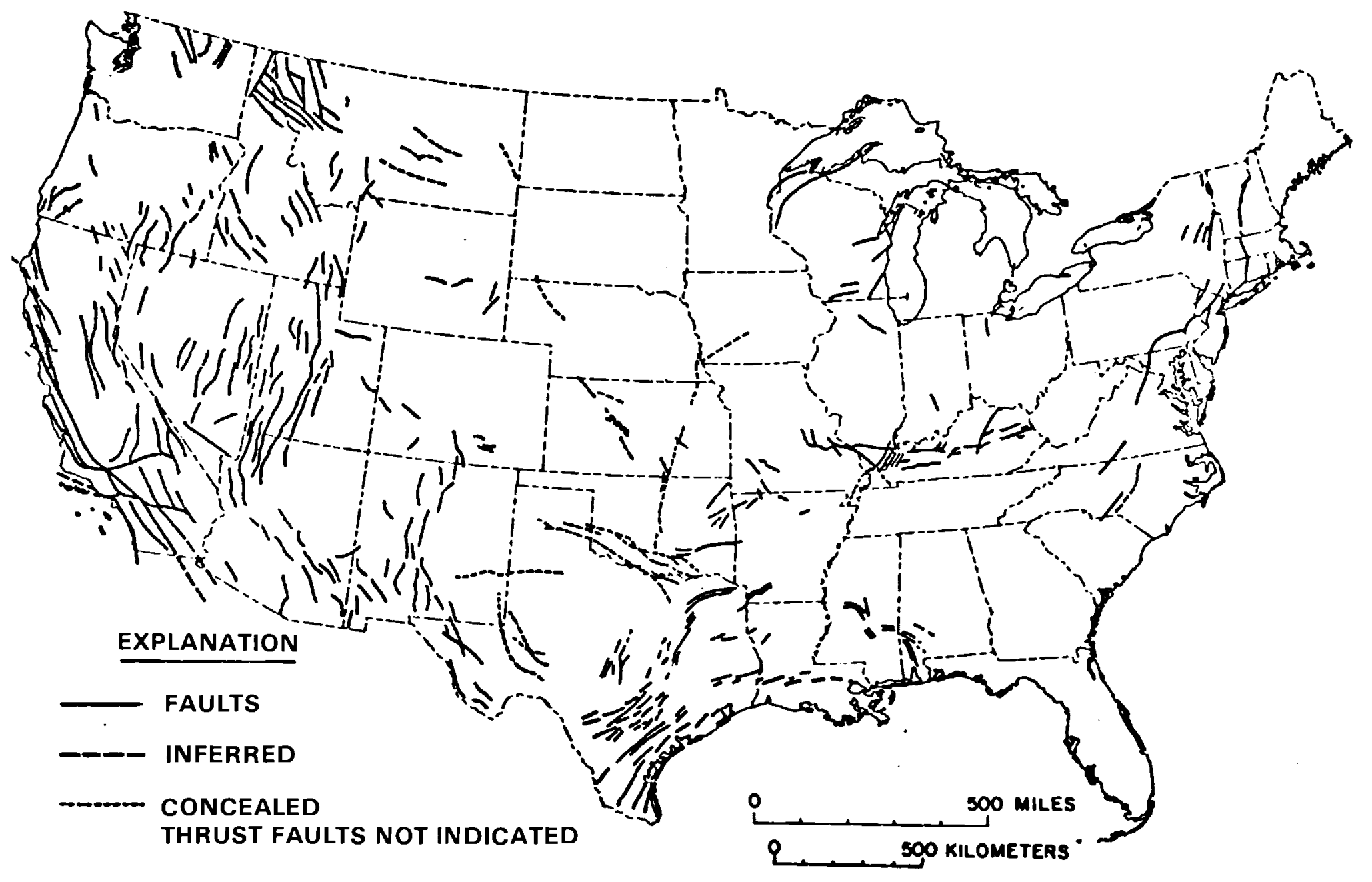

FIGURE 4.16. Principal Faults Located in the Unifed States 
earthquakes in coastal plain areas in the Eastern United States, such as those recorded at Charleston, South Carolina. Zietz and Zen ${ }^{(57)}$ speculated that the Charleston earthquake may be associated with a continental extension of a fracture zone apparently active in the early opening of the Atlantic Ocean.

The seismic risk map, Figure 4.17, is based on the distribution of Modified Mercalli intensities associated with the known seismic history of the United States, strain release in the United States since 1900, and the association of strain release patterns with large-scale geologic features believed to be related to recent seismic activity. (31) zones of seismic risk, rated 0-3, in order of increasing risk, based on no damage to major damage, are shown on this map. Areas of seismic risk 3 correspond to areas that have had the most numerous and most damaging earthquakes.

It is important to note that "...frequency of occurrence of damaging earthquakes was not considered in assigning ratings to the various zones on the risk map..." (Algermissen, 1969), (3i) and thus, the seismic risk map indicates the maximum expected events and not how often such events are expected to occur. Difficulties in evaluating the adequacy of historical seismic data as the basis for assigning risk have made seismic zoning a controversial subject, but most workers seem to agree that reliable assignment of risk requires an understanding of local and regional tectonic processes responsible for earthquakes. Papers in the proceedings of the International Conference on Microzonation for Safer Construction, Research, and Application, $1972,(59)$ give an idea of currently recognized difficulties and methods of evaluating seismic risk.

It is also necessary to note that the seismic risk map depicts the estimated damage potential at the ground surface. For seismic waves arriving nearly normal to the surface, motion is about twice that of points within the earth. (60) Because of these and other probable differences between the characteristics of seismic waves at the surface and at the depths considered in this study of waste disposal concepts, additional studies should be made to determine the response of underground facilities to seismic waves and to define criteria for acceptable ground motions.

In lieu of more comprehensive seismic risk studies and criteria for acceptable ground motions, it is necessary to consider that areas of seismic risk zone 3 are unsuitable for underground as well as surface facilities. Areas in seismic risk zone 2 and less are considered to be potentially suitable if zones of active faulting are avoided.

\subsubsection{Climatic Changes}

Strong evidence is available that indicates extreme climatic changes in the geologically recent past. 


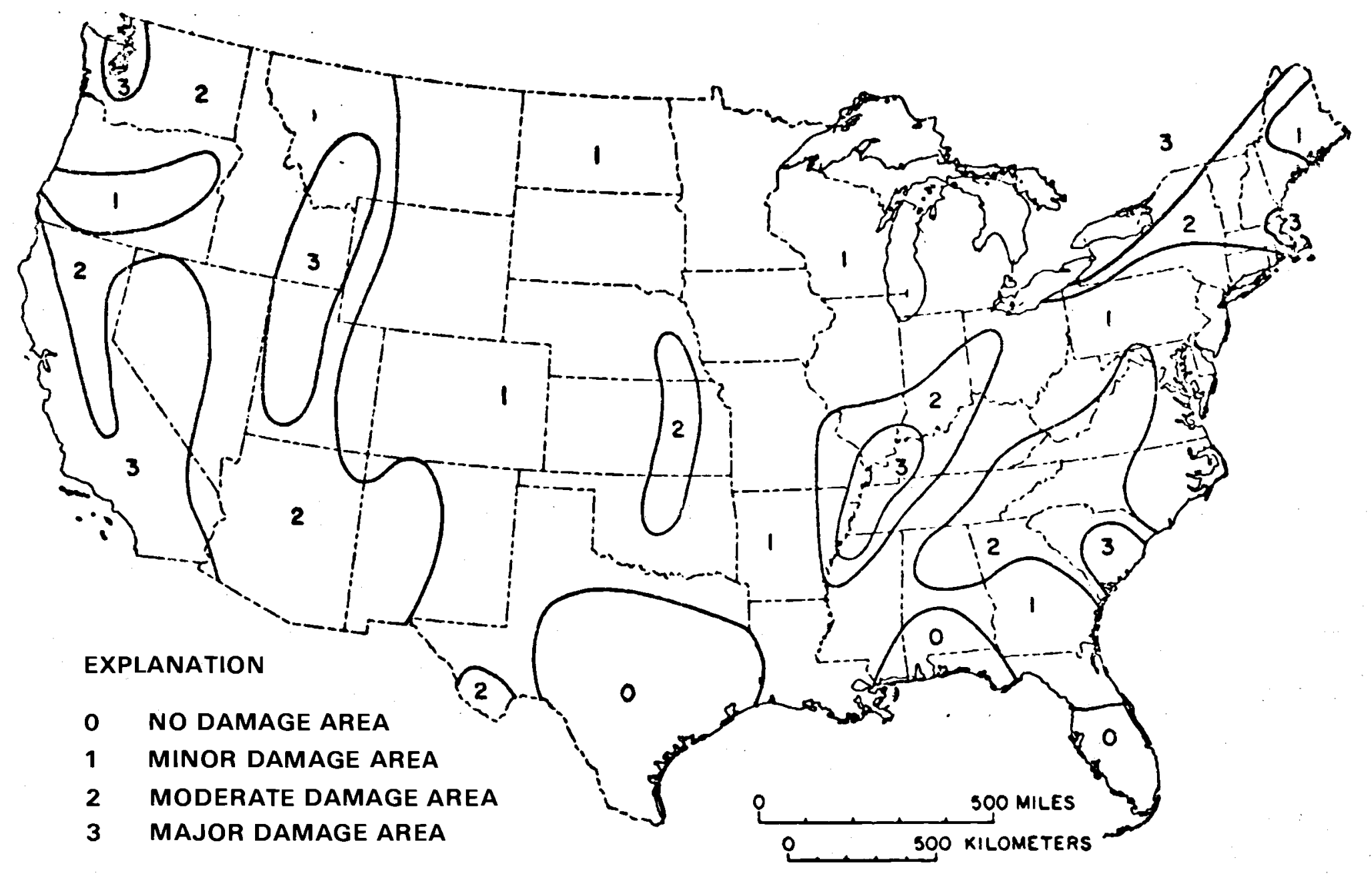

FIGURE 4.17. Seismic Risk Map of the United States 
Therefore, the possibility of climatic changes in the future must be considered when selecting a site for waste disposal. Of principal concern are those climatic changes that will drastically alter the present-day hydrologic regime. These changes include: (1) a possible return of glaciation; (2) a warming trend that would cause a melting of polar ice caps and cause a subsequent rise in sea level; and (3) a return of pluvial climate to arid regions.

\subsection{Effects of Glacial} Climate. Many geologists and climatologists are agreed that the presentday interglacial period will eventually end and an ice age will return. This conclusion is based on the apparent cyclic pattern of glacial activity during the past million years and on evidence from pollen studies that indicate that warm intervals like the present one have been short lived in the geologic past.

Some investigators believe that we are in the final phase of the present interglacial period. Their conclusion is based on a comparison of the last interglacial with the present one. For example, pollen diagrams of the preceding interglacial lake beds so closely parallel the present interglacial records in composition and thickness that basically the same duration could be expected for both intervals. (61) Kukla and Matthews (61) point out that cooling on a global scale is evident in certain key regions in arctic and subarctic latitudes. They feel that man's heat-generating ac- tivities are insufficient, at present, to alter the natural climatic changes, although continuing human input may eventually trigger or speed climatic change. Whether these activities, which include production of dust and $\mathrm{CO}_{2}$, will cause cooling or heating appears to be an unresolved but very important question to the disposal of radioactive waste.

The causes of past climatic changes are unknown. Theories include changes in the earth's magnetic field related to precessional torques, astronomical motions of the earth, (61) volcanism, changes in solar activity, veils of cosmic dust, and changes in atmospheric/ocean curculation. (62) Whatever the causes, only slight changes in temperature are apparently required to cause a shift from interglacial to glacial climates. According to Flint, (62) extreme glacial-interglacial temperature ranges over lands in low altitudes near coastlines may have been as little as $1.7^{\circ} \mathrm{C}$ in mean annual temperature, increasing to $7^{\circ} \mathrm{C}$ or more inland.

It is evident that one or more possible returns to ice ages must be considered in evaluating potential sites for waste disposal. Areas covered by glaciers during past glacial epochs should either be avoided entirely if continued monitoring of the site is required or considered only for concepts that would have at least 1 thousand meters of burial. Areas covered by ice during maximum advances of continental sheets and alpine glaciers are shown in Figure 4.18 . 


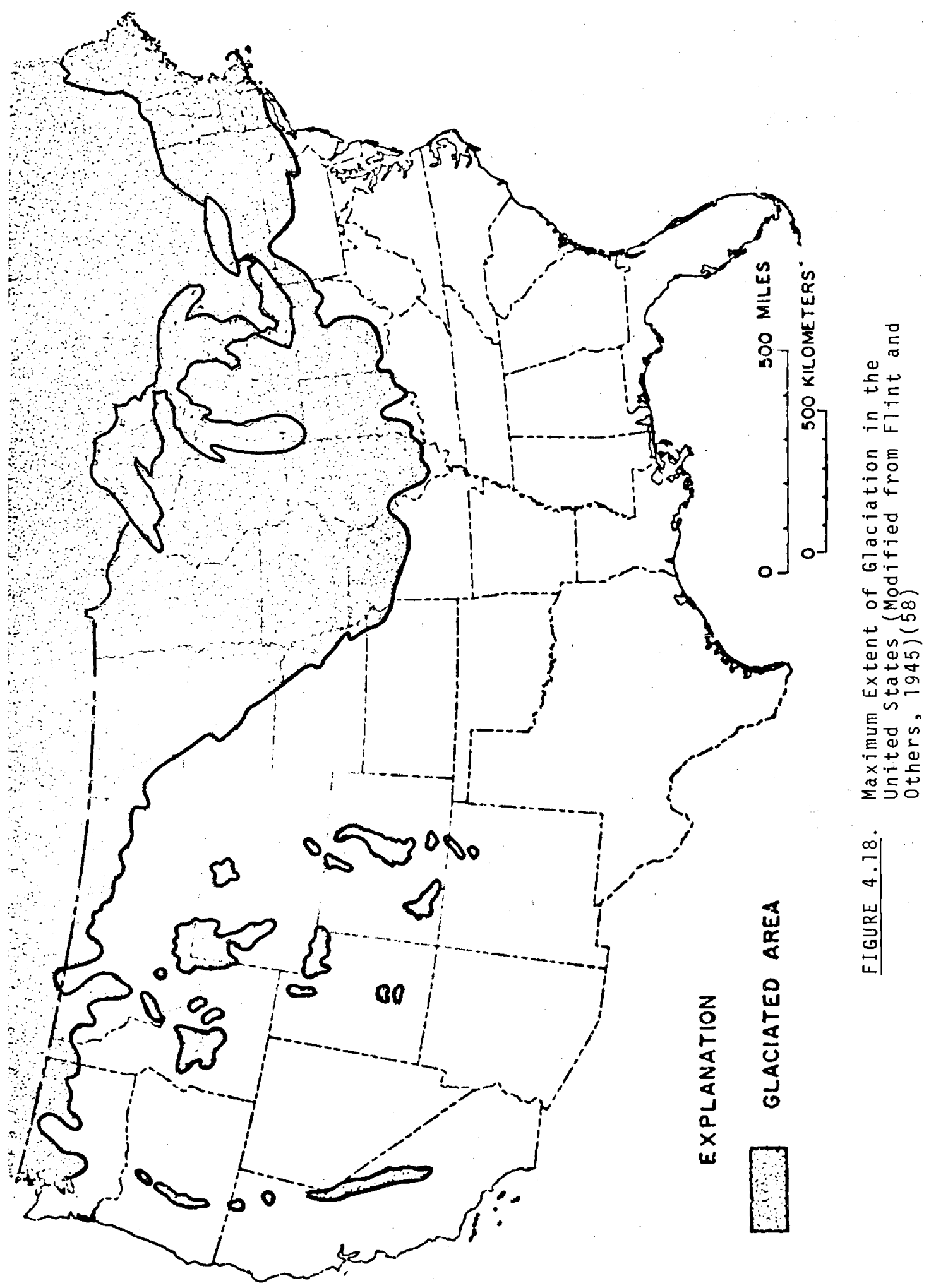


In addition to possible occurrence of ice cover, changes, according to Flint, ${ }^{(62)}$ that could affect potential sites in these areas include (1) drastic changes in drainage patterns including complete obliteration of pre-existing valleys and creation of new ones, (2) overall changes in the hydrologic cycle, (3) creation of new lakes by glacial damming and/or ice melting, (4) cutting and filling of terrain adjacent to glaciers by glacial outwash streams, (5) disastrous flooding by bursting of glacial dams, and ( 6 ) burial of vast areas under windblown sand and silt.

\subsection{Effects of Sea-Level} Change. The sea coasts of the world display a variety of erosional and sedimentary evidence that indicates sea levels have changed dramatically in Quaternary time (Figure 4.19).
Tide gages indicate that changes are presently in progress. (62) In most areas it is not possible to determine whether the changes recorded on land or below the sea resulted from actual rise or fall of the sea or from crustal rise or fall of the land. However, coastilines that appear to have been stable for long periods display sea-erosion terraces as much as 150 meters above the present leve $1(64)$ and as much as 120 meters below the present level. (65) In addition to the obvious effect of advance and retreat of glacial ice, other significant causes of sea level rise include: (1) movement of crust beneath the sea, (2) creation of volcanic masses beneath the sea, (3) draining of inland seas and lakes as a result of crustal movements or erosional processes. (62)

The processes listed above are all capable of causing significant

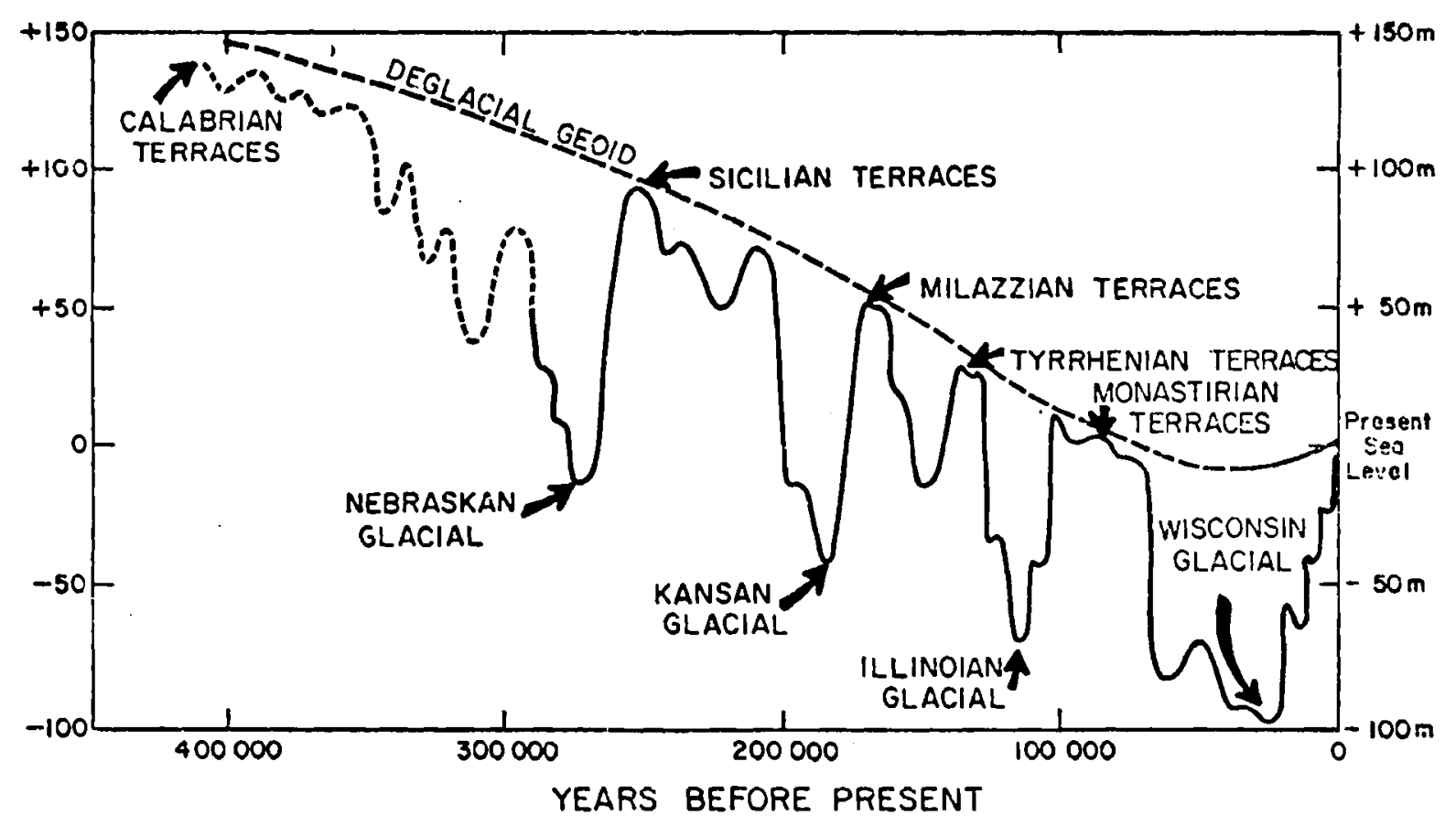

FIGURE 4.19. Quaternary Sea-Level 0scillations

(Modified from Fairbridge, 1961)(59) 
changes in sea level, but for the next million year period the process of principal concern to waste disposal will be the possible melting of glacial ice. If all the ice now stored in the Arctic and Antarctic ice caps were melted, the sea level would rise about 60 meters. $(50,62)$ Although many investigators feel that this possibility is unlikely, others (66) feel that it is almost a certainty, and all the ice could be melted by the year 2050. In view of the overall disagreement among expert climatologists and the lack of firm factual data for predicting climatic change, it is necessary at this time to consider the possibility that large parts of the coastal areas of the United States will be inundated during the next million years. Areas that will be inundated by 60-meter and 150-meter rises are shown in Figure 4.20. All potential sites for waste disposal in these areas, especially those below the 60-meter level, should be reviewed critically.

\subsection{Effects of Pluvial Cli-} mate. The arid and semiarid climate prevailing today in large parts of the Southwest creates conditions that could be hydrologically attractive for waste disposal; however, the possibility of a return to pluvial climate (abundant precipitation) should be considered when planning a site in these areas. A return of pluvial climate will predictably alter the present-day rates of erosion, but more significantly, a return will mean an abundance of, or at least a significant increase in, surface and near surface groundwater. Such an increase would result in greater runoff and the possible development of new and "permanent" rivers and streams, development of lakes in topographical1y.closed areas, and greater recharge to the groundwater reservoirs. Winograd ${ }^{(67)}$ concluded that valley floors of topographically closed basins could become flooded and should be avoided as sites for waste disposal. He further concluded that topographically high areas would continue to receive the most precipitation and that the water table is controlled more by geologic conditions and hydraulic parameters that by climate. The significance of Winograd's conclusions is that a return of pluvial climate presents some problems for waste disposal but that these problems can be overcome by adequate evaluation of hydrogeologic conditions and careful selection of sites for waste disposal in arid or semiarid areas.

\subsubsection{Resource Potential}

In any geologic concept for disposal of high-level waste, a conflict will arise between the use of the earth for disposal and for development of the resource potential that could be available in other forms such as geothermal energy, minerals (i.e., oil, gas, water, salt), surface space and subsurface space. Because disposal will essentially limit the land to exclusive use for geologic periods of time, it must be assured that this portion of the earth is being utilized in the best possible way. It should be considered 


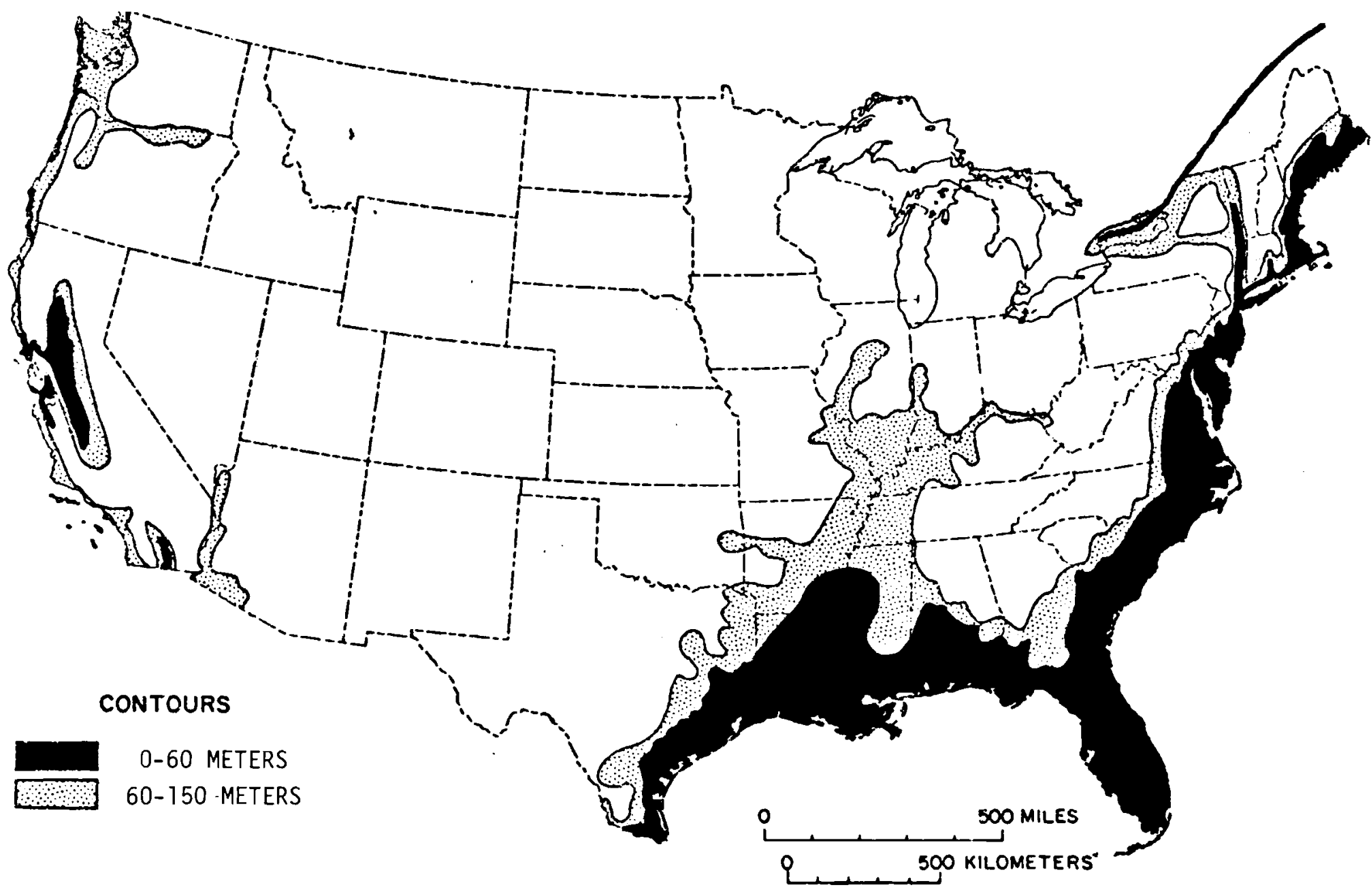

$\dot{\dot{g}}$

FIGURE 4.20. Areas of the United States that Would be Inundated by $60-$ and 150 Meters Sea-Level Rise (Modified from U.S. Geological Survey Maps)(1) 
that man may not be able to monitor or control the disposal area for the total time period required to render the bulk waste harmless. Any geologic disposal concept, therefore, must provide maximum isolation of the waste and present the least possibility of inadvertent intrusion by future generations of man during the development of other potential resources.

Further discussion of resource potential related to the cavity, drilled hole and deep hole concepts will be covered in Sections 4.0.3.9.

\subsubsection{Resume of Preferred Geo- hydrologic and Related Characteristics}

A11 the geologic concepts for disposal of radioactive waste considered in this report are aimed at isolating the waste from man's environment for periods up to about 1 million years. To achieve this, many requirements will have to be met, and although all the disposal concepts have many similarities (e.g., all entail emplacement of waste at some depth within the ground) they nevertheless differ sufficiently that the best location for one mode of disposal may not necessarily be the best location for another. This section of the report outlines the geologic and hydrologic conditions that appear to provide "optimum" or preferred sites for each disposal concept and outlines reasons why a certain environment(s) would be more suitable than others.

\subsection{Mined Cavity Concepts.} Geology and Hydrology. These concepts will probably require a zone of strata with very low permeability at some interval within 3000 meters of the surface. The interval must be sufficiently thick to include zones of very low permeability, over 100 meters thick, both above and below a potential waste disposal cavity to assure that the cavity can be effectively sealed from man's environment.

The mined cavity enables the use of strata insufficiently thick to be practical repositories for drilled hole disposal sites. Of the various rock media potentially favorable for this concept, the most suitable appear to be igneous intrusives, tuffs, shale, and rock salt either in relatively thick beds or in stable domes.

Salt has very low porosity and permeability, which should allow virtually complete hydrologic isolation. In addition, salt has a relatively high thermal conductivity, which should allow good dissipation of heat from the chamber. Mined cavities in salt may be limited to depths of about 1000 meters owing to the natural plasticity of salt and the potential for serious flowage problems at greater depth.

Favorable properties of tuff, some metamorphic rocks, and intrusive igneous rocks include low permeabilities and porosities, and high mechanical strengths. They can be mined with a minimum of structural problems. In tuff at the Nevada Test Site cavities have been mined successfully to depths of as much as 1500 meters. Mined cavities in metamorphic and igneous rocks are feasible as is clearly indicated at Sudbury, ontario, and in deep copper mines in Michigan. In both of these areas the rocks have 
such low permeabilities that the mines are dry, even in the lowest levels. Thermal conductivities of metamorphic and igneous rocks vary considerably from values less than that of salt to levels slightly higher.

The possibility of using shale for mined chambers is attractive from the standpoint of placing waste in rock having both high ion-exchange capacity and low permeability. Shale sequences, however, are rarely without thin permeable interbeds of sandstone and (or) limestone, and the possibility of $f$ inding zones sufficiently thick to assure complete hydrologic isolation of a mined chamber may be limited. In addition, shale is one of the most difficult rocks to mine because of its plasticity. Perhaps the only areas where shale can be safely used for waste disposal are areas where the chamber can be mined well above an existing water table or where evaporation exceeds precipitation. The possibility of eventual water table rise must be considered in these areas because of potential climatic or manmade changes.

Any such natural changes, if they did occur, would probably be slow, and the possibility of the repository remaining above the water table for many thousands of years is likely. During this period the level of radioactivity would be reduced; when (and if) the groundwater would reach the emplacement zone, the high ion-exchange capacity and very low permeability of the shale would impede the outward movement of radionuclide contaminants.

The possibility of using tuff for an above-the-water-table repository is also appealing for the same reasons as outlined for shale. Tuff probably has the highest ion-exchange capacity of the igneous rocks. This property and its low permeability would probably assure slow outward movement of radionuclides in the event that climatic change would cause groundwater to reach the emplacement zone.

The use of metamorphic, intrusive igneous, or volcanic rocks other than tuff is less attractive for above-thewater-table repositories because these rocks have lower ion-exchange capacities than either tuff or shale and, in general, somewhat greater potentials for high permeabilities at shallow depths. Lavas of all kinds are generally unsuitable for this concept because of high permeabilities.

Seismicity and Faulting. Areas of seismic risk zone 3 must be precluded from consideration for mined cavity disposal, and areas in lower seismic zones (especially zone 2) must be carefully mapped and seismically monitored to assure that active fault systems are avoided. The principal danger is that fault movements could rupture either the emplacement zone or the rocks surrounding the chamber and create passageways for groundwater to carry potential contaminants to man's environment. For sites above the water table, in areas where evaporation exceeds precipitation, earthquake rupturing of the chamber or vicinity would not create an immediate hazard, but the possibility of eventual groundwater encroachment during a period of a million years should be considered. 
Climatic Changes. Climatic setting is one of the more critical factors in selecting a suitable location of a site for a mined chamber. To insure the safe long-term containment of radioactive waste in salt, for example, it would be necessary to establish the nature and rates of present-day salt removal by surface waters near the site and the underground dissolution rates by circulating groundwaters. Careful studies must then be made to determine how the rates would be affected by increased (or decreased) rainfall and how changes in regimes of nearby streams might affect groundwater flow systems.

For cavity disposal in these rocks, above present-day water tables, rockerosion rates including both denudation and escarpment-retreat rates must be established. Estimates of how these rates will be affected by possible changes in rainfall must also be made. Calculations must be made to estimate how rapidly a groundwater table could rise with increasing rainfall and how large an increase in rainfall would be necessary to cause precipitation rates to exceed evaporation rates. For cavity disposal in these rocks below about 600 meters in depth, there is relatively small potential danger from climatic changes.

Resource Potential. Areas considered for mined cavity repositories in salt or shale should be evaluated for potential exploitation and/or contamination of $0 i 1$, gas, and water reservoirs, and of salt, potash, and other valuable or potentially valuable com- modities. Areas of tuff, metamorphic, or intrusive igneous rocks that contain known metallic deposits or where extensive hydrothermal alteration suggests the possible presence of such deposits should, in general, be avoided.

Geographic Setting. A site for mined cavity disposal should generally be (1) as far removed from oceans and major lakes and streams as is practicable to extend as long as possible the transit time of contaminants to man's environment in case of accident during transport, loading, or emplacement of waste, (2) the site locality should be as far removed from human population centers as is practicable, and (3) the site should be in as gentle terrain as possible in order to avoid steep drainage gradients that would allow rapid distribution of contaminants in case of an accident.

Advantages and Disadvantages of Mined Cavity Concepts. The principal geohydrologic advantage of the mined cavity concept compared to drilled hole concepts is the potential ability to provide safe emplacement of high-level radioactive waste in a wider variety of media, including salt beds, shale and tuffs that are too thin for drilled hole emplacement. Metamorphic and intrusive igneous terranes which are suitable geologic settings for drilled holes or exploded cavities are also suitable for the mined cavity concepts.

Potential geohydrologic disadvantages of mined cavity concepts compared to deeper disposal concepts include (1) shorter possible flow paths 
of waste constituents to man's environment in the event the integrity of the geologic environment is violated. (2) somewhat higher potential of exhumation of waste by erosional processes, (3) somewhat higher susceptibility to flooding, including rising sea levels, and (4) the higher susceptibility of being inadvertently penetrated by man in the future.

\subsection{Mined Cavity with Sepa-} rate Manmade Structures. From the standpoint of geology and hydrology, this concept is essentially the same as the mined cavity concept discussed above. The manmade structures will be designed to allow a greater degree of retrievability of the waste and to greatly restrict or inhibit movement of radionuclides beyond the cavity for a limited time after the waste is emplaced. Terranes and rocks that are best suited for this concept are the same as those outlined for the mined cavity.

\subsection{Exploded Cavity}

Concepts. Geology and Hydrology. Developing an underground cavity by means of nuclear devices or possibly conventional explosives provides a means of creating a sizeable wasteholding facility without the depth limitations of conventional mining techniques. Cavities have been created by nuclear devices in a variety of rock media at Nevada Test site and other parts of the United States. A concept for using a deep nuclear cavity (chimney) for the incorporation of nuclear fuelreprocessing waste in molten silicate involves in-situ melting of rubble and wall rock by the high-level radioactive liquid waste. (68) Strata of very low permeability, at least 200 meters thick, are required for the model to contain the molten rock at its maximum dimension. (68) In addition, at least 100 meters of rock having very low permeability and completely surrounding the potential molten zone would be essential for safe confinement of waste constituents. The chances of finding such a sequence in sedimentary environments is 1 imited except possibly in shale at depths of 2000 meters or more in deep sedimentary basins. The need for drill hole connections to the cavity for the introduction of waste and the release of volatile constituents for a period of about 25 years (68) further adds to the potential of introducing contaminants to the overlying strata.

The preferred environment, therefore, must satisfy the need for (1) a thick sequence of rock having very low permeability to effectively contain the exploded cavity and the molten mass of waste and rock and (2) rock having very low permeability around the emplacement zone to avoid introducing contaminants into water or oil and gas reservoirs during the period of waste injection and steam release. These requirements are most likely met in metamorphic and intrusive igneous terranes. The optimum locality would be one where metamorphic and (or) intrusive igneous rocks having very low permeabilities extend from or near the surface to great depths. A potential problem that might be hazardous, however, is posed 
by the knowledge that a volume increase due to rock melting and the possible accompanying production of gaseous constituents could result in significant fracturing in these low porosity rocks. Other terranes that appear suitable for this concept are those where thick sequences of tuff form the surface rocks and extend to great depth.

Experiments in Mississippi and New Mexico have shown the feasibility of creating stable cavities in salt by small nuclear devices. The nuclear shot near Carlsbad, New Mexico, for example, (project Gnome) formed a cavity about 20 meters high and more than 45 meters across by means of a 3 kiloton device. (69) Post-shot studies at project Gnome indicate that blast-induced fractures and faults were mainly confined to a radial distance of about 40 meters from the shot point ${ }^{(69)}$ and indicate that setting off nuclear devices in salt may not necessarily create hazardous fractures around the shot point.

Seismicity and Faulting. Areas of seismic risk zone 3 should be precluded from consideration for emplacement of waste in explosion-induced cavities for essentially the same reasons as outlined for the other disposal concepts. The principal danger is that fault movements could create passageways for groundwater to reach the contaminated zone and carry contaminants to man's environment. An additional consideration is the possibility of earthquake activity rupturing the drill holes and creating potential passageways between overlying aquifers and the emplacement zone.
Small amounts of water entering the emplacement zone may not pose an immediate hazard because the water would tend to be driven away by the intense heat. (68) Large amounts of water, however, flowing into the emplacement vicinity could create explosive conditions causing complete loss of emplacement holes and possible loss of the chimney itself.

These potential dangers from fault movements indicate that a site must be mapped in detail to assure that known or projected fault systems are avoided. If buried faults are encountered in exploratory drill holes either in or above the potential cavity, they must be carefully tested hydraulically to determine that they are completely healed. If testing reveals that they are permeable, a new locality should be selected.

Climatic Changes. Except for the need for continuous monitoring of the site there is little danger from potential climatic changes if the cavity is 600 meters or more beneath the surface in rock other than salt. To eliminate possible adverse effects of another variable, it seems advisable that areas of potential sea-level rise or areas occupied by former pluvial lakes should be avoided.

For disposal in an exploded cavity in salt, the same evaluations outlined for the mined cavity apply.

Resource Potential. Areas considered for exploded cavities in salt should be evaluated for potential contamination of oil, gas, and water reservoirs, potash, salt, and other valuable or potentially valuable commodities. Areas of tuff, metamorphic, 
or intrusive igneous rocks that contain known metallic deposits or where extensive hydrothermal alteration suggests the possible presence of such deposits should, in general, be avoided.

Geographic setting. A site for emplacement of 1 iquid waste in an exploded cavity must be in the same 10cation as the reprocessing plant. Therefore, selections of geographic locations for reprocessing plants would have to await geologic and hydrologic analyses to determine the most suitable locations for underground nuclear cavities or other disposal modes. As will be pointed out in the discussion of the deep drill hole concept, the depth involved allows for the possibility of disposing of waste at existing reprocessing plants. An exploded cavity at depths of as much as 6000 meters might also be suitable at some exising reprocessing plant sites, depending on local geologic and hydrologic conditions and the proximity to damage-prone manmade structures.

The main geographic requirement appears to be remoteness from human population centers. Also, because of the potential for release of contaminated steam from the underground facility prior to final sealing, it seems advisable to locate the site as far from oceans, major lakes, and streams as is practicable.

Advantages and Disadvantages of Exploded Cavity Concept. The principal geohydrologic-related advantage of the exploded cavity over the mined cavity is the ability to create cavities at relatively shallow depths (1500-3000 meters) where high underground temperatures or, perhaps, dangerous mining conditions preclude manpower techniques. The main advantage over the deep drill hole and matrix holes is the ability to obtain much larger disposal volumes in one cavity.

The development of radial and other fractures around an exploded cavity compounds the problem of potential hazards from fracture porosity and permeability. For disposal in salt the nuclear device conceivably could trigger diapirism or other deleterious plastic movement. In-place conversion of waste in salt is expected to result in formation of a molten mass of chloride salts of the radionuclides which, when solidified, will exhibit a solubility of the same order as the salt rock. In general, however, terranes and rocks that are suitable for a mined cavity are suitable also for a shallow-depthexploded cavity, and terranes and rocks suitable for deep drill holes are suitable for a deep nuclear cavity.

\subsection{Matrix Drilled Holes} (300 to 6000 meters). Geology and Hydrology. A matrix of drilled holes to depths of as much as 6000 meters provides a potential means of disposing of waste where mining a cavity, forming a nuclear cavity, or drilling a very deep drill hole may be impractical. A thick sequence of rock having very low permeability is required to obtain the necessary waste-holding capacity without drilling an impractical number of holes, each of which 
must be considered as a potential avenue for communication with man's environment. The principal geohydrologic requirement for low permeability is similar to the deep drill hole discussed later. The main difference is a need for rock having very low permeability to be present at shallower depths than is necessary for the very deep dril1 hole $(9,000$ to 16,000 meters) and the potential need for a larger surface area to accommodate additional holes. This latter requirement may not be a critical factor because, in an average environment where a vertical column of thick, very impermeable rock is present, areas can probably be found where such rock is contiguous over lateral distances of many kilometers. The spacing of holes would be controlled by local terrain and drilling conditions, the temperature and chemical properties of the waste, rock conductivity, and other physical characteristics of the host media.

The requirement for a thick sequence of homogeneous rock having low permeability is most readily found in terranes where metamorphic or igneous rocks are near or exposed at the surface or where such rocks are at shallow depth. The possibility of using beds of salt only a few hundred meters thick or sequences of shale for matrix hole emplacement may be possible but is likely to be impractical. Drilling a large number of holes into a thin salt bed to achieve the necessary waste-holding capacity would greatly increase the potential connections to man's environment. The possibility exists that stable salt domes could be used for matrix drill hole disposal if it can be proven that salt will be stable in large-diameter holes drilled to depths of more than about 1000 meters.

Thick sequences of shale occur in several sedimentary basins. (39)

Shale commonly contains many interbeds of permeable sandstone and limestone. Because of the interbeds and the common occurrence of faults and other fractures in the basins, there is limited possibility that waste emplaced in a large vertical column could be effectively contained in shale, especially at shallow depths where porosities and permeabilities of interbeds and fractures could be high. Because of the general decrease of porosity and permeability with depth, exploratory drilling may define shale sequences at some interval within 6000 meters of the surface that could be suitable hosts for matrix drill hole waste emplacement.

The fact that the thick, deeply buried shale sequences occur only in sedimentary basins that are the principal producers of oil and gas indicates that extensive exploratory drilling and hydraulic testing will probably be necessary to prove hydrologic isolation of the potential waste emplacement zone.

Seismicity and Faulting. Crustal stability is essential for safe disposal of radioactive waste in a matrix of drill holes. Because of shorter total hole length, the problem of keeping the hole open if earthquakes should occur is less for the matrix hole than it is for the deep hole concept. Unless hydraulic testing demonstrates conclusively that they are completely healed and "water 
tight," faults within the wasteemplacement zones are undesirable because of the potential for groundwater access and the threat of earthquake activity causing movements to occur along these planes of weakness. A potential site area would have to be mapped in detail and seismically monitored. Exploratory drill holes are economically feasible and should be drilled and hydrologically tested to delineate lithology having the lowest permeability and to locate areas free of buried faults.

climatic Changes. The setting for matrix drill holes should be carefully evaluated if the top of the waste column is within 600 meters of the surface. If the disposal site is in an area of gentle relief, there is little possibility that erosion will actually exhume the waste even in areas that may be covered by glaciers. However, if a climatic change should cause a radical change in precipitation, there is the potential for surface and groundwater regimes to be changed. The site, therefore, must be so selected that the most realistic potential hydrologic change will not create foreseeable avenues for communication of the disposal area with man's environment. Because climatic changes cannot be predicted with any degree of accuracy, it seems advisable to place the top of the waste at least 1000 meters below the earth's surface in any potential site locality having integrated surface drainage.

All areas that conceivably could be inundated by rising sea levels or covered by glaciers or pluvial lakes must be considered less suitable for matrix drill hole disposal than areas that are free from those potential hazards.

Resource Potential. Careful evaluations must be made to avoid areas where mineral deposits are known or where extensive hydrothermal alteration suggests the possible presence of mineral deposits. If terranes are selected where the principal rocks are metamorphic or igneous, the potential exists for drilling into economically valuable metallic or nonmetallic mineral deposits.

If terranes are selected where sedimentary rocks either mantle the surface or are the principal rocks at depth, the potential exists for water, oil, and gas resources. These possibilities would have to be evaluated prior to any exploratory study.

Because of the modest drilling depths under consideration for this concept, there is relatively little likelihood of locating a matrix drill hole repository within a potential source of geothermal energy. Nevertheless, it will be necessary to avoid areas having high geothermal potential.

Geographic Setting. The optimum geographic setting for a matrix drill hole disposal site is a large area of gentle relief. If it is necessary to locate a site in terrane with locally high or moderate relief, the topography may become the principal factor in choosing a suitable site because of the increased potential for landslides and erosion.

The sites should also be located (1) in areas as far removed from population centers, major drainages, 
lakes, and oceans as practicable and (2) in areas of gentle relief to avoid steep drainage gradients.

Advantages and Disadvantages of Matrix Hole Concepts. From the standpoint of concept implementation, a sequence of holes drilled to depths of as much as 6000 meters has the following advantages compared to the very deep drill hole: (1) The shallower holes can be drilled to larger average diameters and can have larger ratios of waste capacity per total length of hole drilled; (2) conceptual preemplacement pilot or exploratory holes are more economical for this mode; (3) drilling problems due to earthquake activity are less likely with shallower holes, and (4) drilling times per unit of hole depth will be much less and several rigs could be employed simultaneously.

Whether a sequence of holes or a mined or exploded cavity would be preferred in any given locality would depend on the geologic and hydrologic information obtained from detailed investigations. For example, if exploratory drilling reveals that rock having low permeability and other acceptable physical and chemical properties exists from 1000 meters below the surface to 6000 meters, then economics and the safety considerations related to access to the disposal 10cation may determine whether a cavity at the 1200-1500 meter depth is preferable to several large-diameter drill holes. Laboratory or actual field tests would have to be made to determine the effects of a concentration of solidified waste in a cavity at 1200-1500 meters or in a series of drilled holes, from the standpoint of heat transfer for the particular rock at the potential site locality.

If exploration revealed that rock at a proposed site with acceptable low permeability and other physical and chemical properties is present only down to about 1500 meters, then that location would generally be more favorable for a cavity concept than for drilled holes (assuming other factors are approximately equal).

4.0.3.9.5 Deep Drilled Hole $(9000$ to 16,000 meters). Geology and Hydrology. Because of the depth involved in this concept and the great physical separation of waste from man's environment that it will provide, it will generally be of little consequence what climatic or other changes might eventually occur that could affect surface conditions. The principal geohydrologic requirement is the necessity for a fairly thick sequence of rock having low permeability to occur below a depth of about 9000 meters. This requirement can be found in a variety of terranes, but the preferred setting is one where homogeneous, low permeability, metamorphic, and intrusive igneous rocks persist from on or near the surface to great depths. Metamorphic and intrusive igneous rocks have high mechanical strengths and can be drilled with a minimum of risks such as caving of the drill hole walls.

Deep sedimentary basins of interbedded rocks having varying degrees of permeability are generally not suitable for this concept because of the typically high potential for regional aquifers and (or) oil-bearing strata. Some basins at depths of 
9000 meters or more may have such low porosities and permeabilities that they may be suitable for deep hole waste disposal, but this would have to be proven by exploratory drilling and extensive hydraulic testing.

Because the characteristics of the upper several thousand meters are relatively unimportant for the deep hole concept, many parts of the United States that are mantled by thin ( 1500 meters or more) layers of permeable sedimentary rocks but are underlain by metamorphic or igneous rocks may provide suitable sites for the deep drill hole. The concept, therefore, offers the possibility of safe disposal of waste at or near processing plants where suitable rock media are not available at shallow or moderate depths.

An important consideration if liquid waste is emplaced in the drill hole is whether or not extensive fractures will develop as a result of the expansion of molten rock due to radiogenic heat. Laboratory and field tests are necessary to determine the nature and extent of such fracturing.

Areas of high heat flow such as coastal California, the Basin and Range Province, Columbia Plateau (including the Snake River Plain) must be regarded as less suitable for the deep drill hole than areas of normal flow. Volcanic activity has occurred in all these areas in the past few million years, and, locally, molten rock may even exist at levels considerably above 16,000 meters. (70)

Seismicity and Faulting. Crustal stability is of extreme importance when evaluating terranes for any waste disposal concept. For deep drill hole disposal, the most important geohydrologic consideration for long-term waste confinement, assuming the waste is emplaced in suitable media, is the potential for fault movement rupturing the zone in or near the waste column and creating passageways for groundwater to enter the disposal area. Good crustal stability is required in order to even drill such a hole. Several years are likely to be required for the actual drilling and preparation of a 9000 to 16,000 meter hole and several more for disposal operations within a given hole. Even moderate earthquakes, if in close proximity to the drill hole, could cause collapse of the hole walls. Therefore, all areas of high seismic risk (zone 3 ) must be precluded from deep drill hole consideration. The selection of sites in other seismic zones would have to await seismic monitoring and detailed geologic mapping to establish the existence of fault systems and the locations of seismically active zones.

The emplacement zone of the hole should be virtually free of faults, whether currently active or not, because faults could provide potential avenues for fluid movement. Great depth should contribute to sealing of faults. However, great depth may not necessarily guarantee that faults and fractures will be closed and healed despite the knowledge that porosity and permeability generally diminish with depth, (Figure 4.21). (71) Hydrologic testing at the Nevada Test Site revealed that fractures had low to moderate permeability at least to 4160 meters, (72) and fractures below 6000 meters in a drill hole in the Delaware 


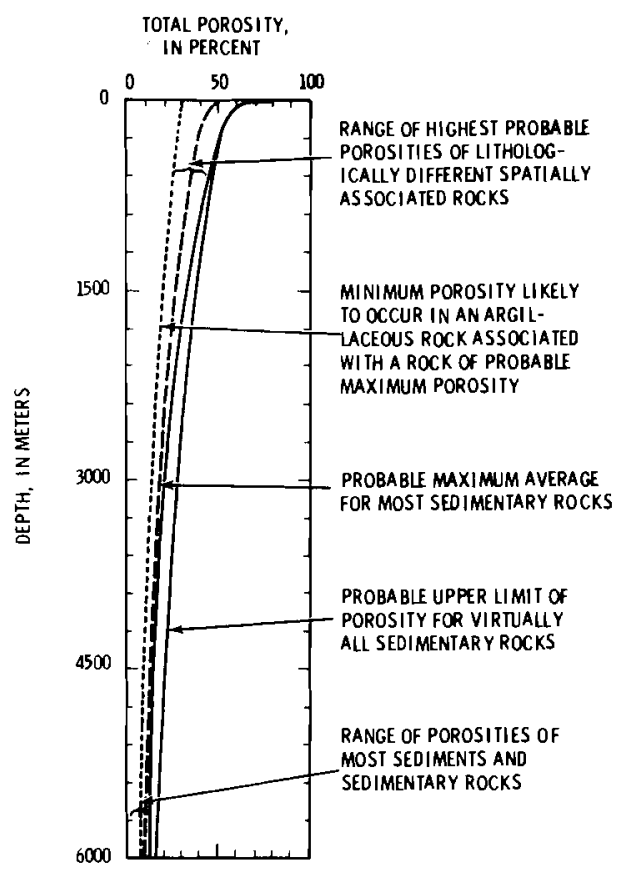

FIGURE 4.21. Total Porosities of Sedimentary Rocks Versus Depth (Modified from McCulloh, 1967)(71)

Basin of Pecos County in Texas were found to be permeable. Potential sites must also be carefully evaluated to ascertain the possible presence of buried low-angle or thrust faults. Areas known to be characterized by such faults or areas where they have been logically inferred should be avoided.

Resource Potential. The possibility of damaging or destroying a potential resource must be evaluated for all concepts, but for the deep drill hole the possibility of damaging a potential source of geothermal energy must be especially evaluated. Areas of high heat flow such as coastal California and the Basin and Range province, are areas where the probability of penetrating an economic source of geothermal energy is very high. Volcanic activity has occurred in both of these areas in the past few million years. A close spatial and temporal relationship between volcanic activity and geothermal activity has been outlined by Grose. (73) Active hot spots in the crust are generally known by the occurrence of geysers, hot springs, etc.; other hot spots probably are present at depth but will be found only by deep drilling. Therefore, in deep drill holes the disposal of high-level waste must be regarded as less suitable in areas of high heat flow than in areas of normal flow. In some areas of high heat flow, molten rock may even exist at levels considerably above 16,000 meters. (70)

As previously discussed, valuable $0 i 1$ and gas bearing strata are commonly found in sedimentary environments. This potential for connection between a deep hole disposal site and such resources in sedimentary basins may be possible, even at great depth. Natural gas is now being produced at depths as great as 7500 meters in Oklahoma. (74)

Geographic Setting. A site for deep drill hole disposal should be (1) as far removed from oceans and major lakes and streams as is practicable, (2) as far removed from human population centers as is practicable, and (3) in as gentle terrain as possible in order to avoid steep drainage gradients that could allow rapid distribution of contaminants in case of accident.

Advantages and Disadvantages of Deep Drill Hole Concepts. The principal advantages of the deep drill hole 
concept compared to other geologic concepts include (1) a wide variety of potential sites with the ability to provide safe emplacement of highlevel radioactive waste in desirable geographic locations where suitable rock media do not exist at shallow or moderate depths and (2) the ability to place the waste 23 far from man's environment as possible.

0 ther attractive features of the deep drill hole are (1) elimination of danger of exhumation of waste by any erosional process, including glaciation, and (2) elimination of dangers from flooding, including rising sea levels (assuming complete sealing of unused portion of drill hole).

The principal disadvantages of the deep drill hole appear to be largely operational. Probable high drilling expense and long drilling times would be required especially in hard metamorphic and igneous rocks. In addition, exploratory or pilot holes to assure suitable rocks at the depths under consideration would also be 1 imited by time and expense.

\subsubsection{Radionuclide Migration in} Soils

One of the major considerations associated with either storage or geologic disposal concepts will be the selection of sites where the possibility of groundwater or surfacewater intrusion is essentially nil. However, even if water somehow contacted the waste, the remoteness and the characteristics afforded by certain geologic formations could significantly delay the time of arrival of dispersed radionuclides into man's immediate environment. Obviously, radioactive decay associated with any delay retardation of nuclide migration could reduce radiological consequences of an unexpected release. Furthermore, chromatographic separation of radionuclides could segregate radiological doses that would otherwise be additive. The nuclide retention and separation results from the fact that many of the species that might be leached from solid products during an incident involving water contact would subsequently react with and be retained by the host media or surrounding sediments.

Mechanisms for retention and separation (fractionation), as the result of radioactive solutions percolating through the sediments, include ion exchange, precipitation, and replacement. Ion exchange is a special case of sorption where species moving in or out of the sorbing media are ions rather than molecules. Many solids, when placed in contact with solution, simply exchange ions with similar chemical species that are present in solution. "Fertilizers contain soluble ammonium and nitrate ions. One reason these ions are not washed away from the surface of the soil is that they exchange with other ions in the soil and are then held by insoluble minerals."(76) In layered silicates and zeolites of the silt and clay size fractions of sediments, cation exchange can be the predominant reaction for the removal of radionuclides. (77)

The formation of gelatinous, insoluble aluminum hydroxide during water treatment is a good example of a precipitation reaction. Many chemical salts remain in solution primarily 
under acidic conditions. However, when an acid waste solution enters calcareous soil, free carbonate tends to neutralize the acid in the water, resulting in the precipitation of various nuclides as insoluble hydroxides. Additional details concerning soil sorption reactions are presented in Reference 77 where emphas is is placed on retention mechanisms for Sr-90, Cs-137, Co-60, Ru-106, plutonium, transition metals and rare earths.

Evaluation of the extent of confinement afforded by the retardation and separation potentially associated with geologic formations obviously requires the definition of a particular site. The depth and mineralogy of the host media and the surrounding sediments as well as the areal climate must be described to evaluate the relative importance of the above sorption reactions in relation to a particular waste constituent. Ionexchange capacity and the thickness of the unsaturated zones of arid or semiarid regions of the southwest are qualitatively discussed in relation to the retardation of nuclide transport in Reference 67. It should also be noted that any final evaluation of a specific site must consider the possibility that the dispersed but sorbed nuclides could conceivably become a contamination source, e.g., as the result of changes in water chemistry. Methodology for providing quantitative estimate of the orders of magnitude of retention and retardation that could be expected from reactions in a typical desert soil following a postulated release incident was presented in section 3 .

\subsubsection{Excavation and Sealing Infor- mation Relevant to Waste Disposal}

All of the geologic storage or disposal concepts require some form of excavation to provide access to the region selected for waste emplacement. After waste emplacement the access must be closed and sealed from man's environment for hundreds of thousands of years. The techniques and technology for hole forming, cavity formation, and access sealing relevant to waste disposal are summarized in the next two paragraphs. The sections following give a brief review of these areas.

In general, technology and methods seem to be adequate to produce the excavation needed for the waste disposal concepts under investigation. The one notable exception is the lack of demonstrated capability and technology to form a modest sized drill hole up to $16 \mathrm{kilometers}$ deep. One study suggests that forming such a hole may be feasible with existing equipment and technology for locations having low geothermal temperature increases with increasing depth. (78) Unpredictable conditions at depths below those explored (about 9 kilometers) could cause major complications and delays in an attempt to reach full depth and/or desired diameter at full depth. Bigger equipment and select technological improvements are 1 ikely to be required. 
Technology for sealing cavities and drill holes is reasonably well developed for seals which maintain integrity on a short-term basis. Existing seals have accomplished their goals for the time they have been in place. Unfortunately, these test times are on the order of 10 to 50 years rather than the hundreds of thousands of years required for waste disposal. A carefully planned development program should lead to seals having a high assurance of a predictable long 1 ife.

\subsubsection{Hole Forming}

As referred to here, this is simply a method of forming a hole, usually near vertical, with all man's activities performed at the earth's surface. Drilling is the most frequently used method for holes over a few hundred meters in depth and no larger than a few meters in diameter.

\subsection{Conventional Drilling.} In conventional drilling a rotating drill bit is used within the hole. The bit is powered from the surface through connecting drill pipe.

Great depths could perhaps require techniques which eliminate the rotation of the shaft. Promising ways of doing this include locating the motor for rotation near the hole bottom or using graduated driliing or melting techniques. A few details about these methods are given below. The general information presented was obtained from Reference 79 unless otherwise noted.

The boundaries of drilling experience such as depth, diameter, and drilling rates are of interest in indicating when development would be needed for a particular concept. Depth is discussed first. The most recently reported depth record is 9135 meters. (80) This record hole required about 2 years to drill and is now producing gas at the 5180 meter depth. The particular geologic formation thought to lie at about the final depth was not reached. The reason for terminating the drilling is unknown but appears to be economic. The hole diameter is stepped in size as follows: 44 centimeters to 4700 meters, 32 centimeters to 7300 meters, and 20 centimeters to 9135 meters.

During 1972, 506 holes were drilled to deeper than 4600 meters and 49 holes were drilled to deeper than 6100 meters $(80)$ in the United States. The numbers of holes greater than these depths have been generally $(79,80)$ increasing yearly. An attempt at an 8800-meter hole is under way. (81)

The depth boundaries described above are adequate for all needs identified in this report except that of the 16,000-meter hole. In this case the most relevant data is a study by Fenix and Scisson, Inc. (78) Direct quotes excerpted from their conclusions are:

- "It is feasible to drill a hole to 16,000 meters.

- Equipment required to drill the projected hole is available at this time (May, 1969). Some items of equipment should be subjected to additional development to improve performance and safety. Specifically 
the items needing development are: drill pipe, downhole motors, and bits. - Casing, cement and cementing services, along with circulating fluids for use at the assumed temperature and anticipated depth are available. - The estimated time to drill the hole is from 4 years, 9 months to 6 years, 6 months, dependent upon the area selected.

- The estimated total cost of the hole is from 19.5 million dollars to 26.7 million dollars depending upon location and intermediate casing strings required. These cost estimates, along with others shown in this report, do not include a contingency allowance, nor do they include the cost of administrative overhead or an architect/engineer. (Note: The cost of subsequent holes should be in a lower range because of experience gained on the initial hole.)

- The most expedient and economical method of drilling would be to penetrate the upper 6000 to 9000 meters with a currently operational drilling system. Depending upon final criteria the drill rig could continue the drilling to depth or be replaced completely, or in part, with components of greater capacity. Development and testing of special tools for the project should be completed during the drilling of the upper portion of the hole.

- A possibility exists that fractured formations, caving hole, seismic activity or other conditions may be so severe that it will be imprac: tical to proceed. In this eventuality the project should be moved to a more favorable location or abandoned."
Based upon these and other studies, it is concluded that a small diameter (1ess than $10 \mathrm{~cm}$ ) 16,000 meter deep hole is feasible with today's equipment in areas of low geothermal gradient (i.e., where down-hole temperature are lower than typical). For holes of the diameter required for radioactive waste disposal and for areas with nonlow downhole temperatures, necessary equipment is not yet available, and considerable research and development may be required.

To provide perspective on the size of deep-drilling equipment the rig description for the 9135 meter hole is given below: (82)

The largest in the world, Rig 32 is equipped to drill below

9,100 meters.

The 2,235 kilowatt drawworks

is powered by three 1,000 kilowatt electric motors. The 43 meter mast has a gross nominal capacity of 910 metric tons, rotary capacity of 730 metric tons and a setback capacity of 500 metric tons. The crown block is the world's

1 argest, with a capacity of 860 metric tons. Hook and traveling equipment are rated at 680 metric tons.

other equipment includes two 1,230 kilowatt mud pumps, a 431 cubic meter active mud system, and 632 cubic meters of reserve mud capacity. A 1020 atmosphere working pressure BOP (blowout prevention) system is the largest ever fabricated.

Certain items in drilling experience have bearing upon the potential for drilling a 16,000-meter hole.

They include rotating drill table capacity, dril1 pipe strength, bit strength and design, and downhole temperature, pressure, and rock competence. Each is briefly and independently discussed with respect to its effects on drilling 16,000-meter holes. All factors could possibly 
combine to defeat such an effort short of the point each might cause failure separately.

The mechanical connection between large engines and the pipe is made by a device called a rotating table. It is designed to transfer power at some maximum rate. The largest table in use within the United States is rated at 14,000 kilogram-meters of torque. Downhole friction must be overcome to rotate the bit. The total friction increases with depth until ultimately a point may be reached where the bit cannot be turned. Present rotary tables are expected to have the needed capability for 16,000-meter holes.

A table with twice the capacity of the current maximum appears technically feasible but there presently appears to be no incentive to build such a table in the oil industry. The larger table could allow an increase in the drilling rate at any instant by about 40 percent. To the extent that maximum depth is friction limited and that friction depends upon the total rotated surface area, the possible hole depth could be doubled for each drill diameter used. Thus the rate at which hole size decreases (by steps) with depth could be reduced. Applying the same logic, the diameter could be doubled at a given depth. Note, however, that both cannot be done simultaneously and that these simple estimates are only absolute upper bounds rather than actual experience.
Drill pipe strength also has significant bearing on the achievable hole depth. Adequate drill pipe is available for drilling a small diameter hole to $16 \mathrm{kilometers.} \mathrm{The}$ safety margin, however, is not as great as usually used, and the chance of twisting off the drill pipe is greater. (78) A broken drill pipe is frequentiy not recoverable. The tensile loading on the pipe is made up of two major components: 1) the twisting load in turning it and 2) the static load of the pipe, bit, and the drill collar. (a)

Presently available drill bits may be adequate for a 16-kilometer, 70 centimeter diameter hole or a 2.6-kilometer, 3-meter hole. (78) Better bits, however, would speed up the average drilling rate by reducing the number of times they have to be changed.

The earth's temperature typically increases with depth at a rate of about 15 to $30^{\circ} \mathrm{C}$ per kilometer depending on the location. Extrapolation of this rate of increase suggests that there are areas where a 16-kilometer hole can be drilled without exceeding the temperature limits of existing equipment. Currently, drilling muds are 1 imited to use at up to about $260^{\circ} \mathrm{C}$. Higher temperatures can cause increased drill bit wear, drill bit failure, decomposition of muds, problems with premature cement settina, and reduction in downhole material strengths. This implies that for a 16-kilometer

a. A drill collar is a series of weights which load the bit for optimum drilling pressure. 
hole either an area having an average geothermal temperature increase of about $16^{\circ} \mathrm{C}$ per kilometer must be chosen, or higher temperature drilling muds must be developed.

Denser muds are required for the higher temperatures and pressures encountered in deep drilling. These muds are more difficult to handle than conventional muds, causing an overall increase in drilling costs.

Hole collapse, water invasion, and drilling mud loss are three related and currently encountered problems which may be anticipated in a 16-kilometer hole. All can be minimized by either casing the hole or locally cementing the formation.

At some depth for a given diameter, the hole cannot be cased using existing equipment because of equipment and casing strength limitations. A depth limit of 12 kilometers for 70-centimeter casing has been estimated. (79) A proposed 8.8-kilometer hole has already a record 4.3-kilometer, 36-centimeter casing weighing about 680 metric tons. (82)

Diameter can be discussed at least partially exclusive of depth. The record large diameter holes drilled are shown below in Table 4.14 as a function of depth.
These 1 imits are adequate for almost all large diameter needs of the identified concepts. The possible exceptions are those concepts requiring manned access at the hole bottom for holes deeper than about 1830 meters. Fenix and Scisson(79) feel 2400 meters is the maximum depth for a larger than 180-centimeter diameter hole using existing equipment. They believe larger equipment is possible.

The generally inverse relationship between maximum hole depth and maximum diameter makes it necessary to consider what the maximum depth is for a diameter which is suitable for a solid waste canister. Forty-three centimeters is considered the reference hole diameter for the drilled hole concepts in this study. The record hole $(80)$ described previously reached 4700 meters at this diameter. Data on drilling a 43-centimeter diameter hole to depths greater than the record 4700 meters has not been generated, primarily because the oil and gas industry has apparently not had either the technical need or economic justification for it.

Drilling rates are an important factor in the cost of drilling holes. For waste disposal they are additionally important in the logistics of

TABLE 4.14. Large-Diameter Drill Hole Depths (79)

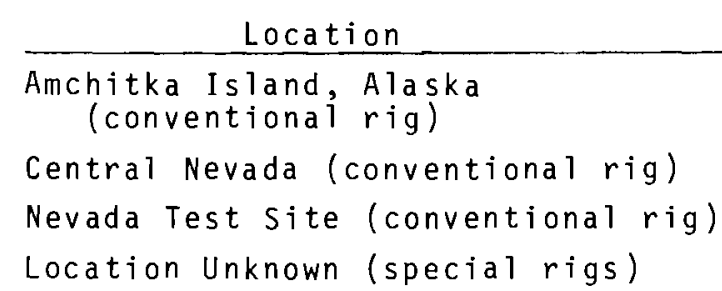

Hole Depth, Hole Diameter, (meters) (meters)

$1,900 \quad 2.3$

$1,700 \quad 3.0$

$90 \quad 4.1$

$210-240>4.0$


implementing a selected disposal concept. Rates vary extensively with rig size, drilling depth, and material being drilled. A significant factor affecting rate as depth increases is the time required to change drilling bits (trip time) since increasingly more drill shaft sections must be handled. In recognition of these variations, "average" drilling rates have been tabulated in Table 4.15.(79) Shown also is a record fast time drilling rate for a 5300-meter hole. The demonstrated drilling rates do not appear to place a controlling burden on the geologic disposal concepts under investigation.

Drilling typically requires recirculation of a fluid (drilling mud) as a means of lubricating the shaft and bit, cooling the drill bit, transporting the hole drillings to the surface, and equalizing hydraulic and lithologic pressures at depth. Drilling muds normally consist of various materials dissolved in or slurried with water. Cleaning the drilling mud and water out of the holes after drilling is important for waste disposal. Holes have been cleaned for a wide array of underground nuclear tests, such as the 1900-meter hole at Amchitka Island, Alaska, and for 1 iquified petroleum gas (LPG) storage cavities. A gradual reduction of drilling mud density to that approaching clean water while maintaining fluid circulation may be a possible technique of hole cleaning. The water could then be pumped out; the hole cased and cemented; and finally residual water pumped out, resulting in a clean dry hole.

Deviation of a drilled hole from the vertical is an important consideration as it affects hole location. Two types of drill deviation can be encountered. One is geology dependent; the other a random effect controlled by other aspects of the drilling process. The first type,

TABLE 4.15. Typical Drilling Rates Versus Hole Depth
in Relation to Time $(79)$

\begin{tabular}{|c|c|c|c|}
\hline $\begin{array}{l}\text { Hole Depth } \\
\text { (kilometers) }\end{array}$ & Data Basis & $\begin{array}{c}\text { Estimated } \\
\text { Drilling Rate } \\
\text { (meters/day) } \\
\end{array}$ & $\begin{array}{c}\text { Tota } 1 \\
\text { Dri } 11 \text { ing } \\
(\text { days })\end{array}$ Time \\
\hline 5.3 & Experience & $53^{(a)}$ & $100^{(a)}$ \\
\hline 0 to 4 & Experience & 18 & 250 \\
\hline 6 & Experience & 18 & 350 \\
\hline 8 & Experience & 18 & 470 \\
\hline 10 & Extrapolation & 15 & 600 \\
\hline 12 & Extrapolation & 10 & 800 \\
\hline 14 & Extrapolation & 4 & 1300 \\
\hline 16 & Extrapolation & 1 & 2700 \\
\hline
\end{tabular}

a. Record fast drilling job. 
geology dependent, occurs rather reproducibly in adjacent holes and is caused by such features as tilting in the rock bedding planes. Thus it occurs to about the same extent in the same direction at the same depth in adjacent holes. Two solutions to the geology dependent deviation are thus apparent. First, as drilling proceeds, compensation for the deviation can be made at known points in a planned fashion based upon past experience. The second alternative would permit the hole to deviate from vertical if none of the design goals are compromised. For example, a design goal that all holes must have uniform spacing can be achieved if each hole deviates in a like manner. Correcting this type of deviation may require several trial and error holes to develop an adequate system, but the oil industry routinely moves in the direction of straight holes as they proceed to drill a field.

The second type of deviation, random, can only be controlled in a particular hole by frequent monitoring followed by corrective directional drilling. The monitoring can be done as often as desired, but does increase the cost of drilling. Directional drilling is a well developed art, but does require more time to accomplish and to monitor the results. $A$ hole can be redirected from $1 / 2$ to about 5 degrees over about ten feet of drilling.

A quantitative measure of the nominal deviation from vertical has not been established. However, it appears that $1 / 2^{\circ}$ to $2^{\circ}$ is not an unreasonable goal. Typical specifica- tions for oil well drilling are 3 to $5^{\circ}$ off vertical overall, with no sharp "dog legs."

\subsection{Advanced Hole Forming} Technology. Work upon advanced drilling and cavity formina techniques has been reported. (83-87) Nonconventional or novel forming techniques can be classified by the basic mechanism utilized for rock removal. (83) The various mechanisms include: 1) fusion and vaporization, 2) thermal spalling, 3) chemical reactions, and 4) mechanically induced stresses. The specific novel methods reviewed for this study have been classified according to these rock-removal mechanisms and are presented in Table 4.16. Conventional drilling falls in the last category.

Fusion and Vaporization Drills. Fusion and vaporization drills must operate at the rock melting temperature. The melting temperatures of most rocks range from 1000 to $2000^{\circ} \mathrm{C}$, and the specific energy required to fuse rock range from 4,000 to 5,000 joules per cubic centimeter. Strong igneous rocks such as granite and basalt have lower fusion energy requirements than weaker sedimentary rocks such as sandstone and 1 imestone. This suggests that fusion drills will find initial application for drilling these strong igneous rocks.

Electric heater drills (88) and nuclear drills ${ }^{(89)}$ are similar except for heat source. Both melt the rock and remove it as a liquid which is solidified to "popcorn-like" particles which are blown out of the hole. The subterrene, a particular hole 
TABLE 4.16. Classification of Novel Drills

Fusion and vaporization drills

Electric heater (subterrene)

Electric arc

Nuclear

Electron beam

Plasma

Thermal-spalling drills

Jet piercing

Forced flame

High-frequency

Fluid contact

Chemical drills

Fluorine

Mechanical drills

Explosive
Erosion
Turbine (single stage)
Pellet

Explosive

Turbine (single stage)

Pellet
Implosive

Continuous penetrator

Ultrasonic

Spark melting device, shows potential for applications in the future and is one of two drills under active development at the Los Alamos Scientific Laboratory. The device bores holes in rocks by progressively melting them instead of chipping, abrading, or spalling them away. The energy requirement for melting rock is relatively high, but may not be prohibitive. Common igneous rocks melt at about $1200^{\circ} \mathrm{C}$ and, in being heated from $20^{\circ} \mathrm{C}$ to just above their melting ranges, they absorb about 4300 joules of energy per cubic centimeter. In comparison, the corresponding figures for rotary drilling in most igneous rocks is about 2000 to 3000 joules per cubic centimeter. Even for a penetrator of very large diameter advancing at a high rate, the melting energy can easily be provided by a compact, high-temperature, nuclear reactor. Energy transfer from the reactor to a melting tool at the rates and densities required will be by means of heat pipes.

The rock-melting drill has so far been developed only to the stage of a smal1, functional, electrically heated prototype. Tested in this form, it has been shown to penetrate basalt and other igneous rocks at usefully high rates and with moderate power consumptions. As it advances, the penetrator forces molten rock laterally into voids in the unmelted rock around the bore, and backward around the periphery of the penetrator. The molten rock freezes in these locations, producing an obsidian-like glass lining on the wall of the hole which helps to seal and support it. The lining also forms a seal around the penetrator, tight enough to permit high pressures to be developed in molten rock ahead of $i t$. 
The formation of holes up to 25 meters deep and 7.5 centimeters in diameter has been demonstrated in field tests.

Electric arc drills operate at 5,000 to $17,000^{\circ} \mathrm{C}$ and can fuse holes in any rock. Work has been done by several organizations. (83) As an example, Drilling Research, Inc., $(90)$ used an electric arc to spall and fuse craters in flint, limestone, and sandstone. Craters ranging in volume from 13 to 16 cubic centimeters were formed in 6 to 15 seconds in air. In one underwater test, a crater having a volume of 14 cubic centimeters was fused in sandstone in 120 seconds. No spalling occurred in this underwater test.

Plasma generators or plasma arc drills produce temperatures up to $17,000^{\circ} \mathrm{C}$ and are capable of fusing holes in any rock. Plasmas are produced by passing electrical current through a gas such as helium or argon which is passing between electrodes at velocities of 200 to 7,500 meters per second. Plasma drills are highvelocity, high-heat-transfer devices. Bouche ${ }^{(91)}$ used a plasma arc to spall and fuse holes in various rocks. This plasma had a 7.5-centimeter flame having a temperature of $5,000^{\circ} \mathrm{C}$ at the electrodes and $1,800^{\circ} \mathrm{C}$ at a distance of 2.5 centimeters from the electrodes.

Electron-beam dril1s (92) produce power concentrations up to $1.5 \times$ $10^{9}$ watts per square centimeter, sufficient to fuse holes in any rock. Electron beams are produced by accelerating electrons from a cathode toward an anode using potentials of 5 to $150 \mathrm{kilovolts.} \mathrm{The}$ electrons emitted from the cathode are focused against the rock by means of a bias grid along with electrostatic and electromagnetic lenses. Electron beams have been used to drill holes in rubies and other minerals, but no large-scale drilling tests have been performed. Laser drills ${ }^{(93)}$ can produce power concentrations of $1.5 \times 10^{12}$ watts per square centimeter, which is sufficient to fuse holes in any rock. A laser beam is produced by exciting or "pumping" a group of atoms in a crystal or gas to their higher energy state and then dropping them back to their lower energy state. As this drop occurs, the atoms emit photons of the same frequency, producing a coherent light beam. Flash tubes are used to excite ruby crystal lasers. These crystal lasers can be used only in short bursts because over 99 percent of the pumping energy is lost to the cooling fluid, and heat dissipation is a problem.

At this time it is not possible to predict if any of the fusion and vaporization concepts will work on a commercial scale and if so, which are best. However, the concepts provide a wide range of power outputs. Thus, if a number of concepts work, presumably the final choice would be that method which is the most effective and does not use excessive power. The media used for transporting the drilling energy varies from a solid to photons, which provides for a considerable range of application. All fusion and vaporization methods will require a number of downhole cables and complex equipment. 
Thermal spalling Drills. When the surfaces of some rocks are rapidly heated to 400 to $600^{\circ} \mathrm{C}$, thin flakes or "spalls" of rock break off the surface. This process, called thermal spalling, produces long, thin flakes. These spalls are produced by thermal stresses resulting from differential thermal expansion of the constituent crystals and grains.

$$
\text { Jet-piercing drills, (94) which }
$$
were introduced into the mining industry in 1946, are widely used for drilling taconite and other silicate ores. They burn oxygen and fuel oil to produce a flame having a temperature of $2400^{\circ} \mathrm{C}$ and a velocity of. 1800 meters per second. Water is used to cool the combustion chamber and the burner nozzles. This water also solidifies the molten rock and is converted to steam, which assists in removing the disintegrated rock from the hole bottom. Jet-piercingdrilling rates range from 0 in 1 imestone to 12 meters per hour in some taconites and quartzites.

Forced-flame $(95)$ or rocket-exhaust drills are similar to jet-piercing drills except that they use nitric acid as the oxidizing aqent instead of oxygen. Nitric acid produces a faster reaction, resulting in higher power output and faster drilling rates. A field-tested, forced-flame drill penetrated iron quartzite at 18 meters per hour, compared to 5 meters per hour for a jet-piercing drill.

Numerous tests have shown that high-frequency electric current can be used to break and crush conductive rocks such as iron ore. (95) This technique could be used to drill rock. These devices heat rock by dielectric heating and by resistance heating. Dielectric heating occurs due to the rapid switching back and forth of the dipoles, while resistance heating is produced by electric current passing through the rock between the electrodes.

Kravchenko ${ }^{(95)}$ used 240 kilocycles/ second current to heat and break blocks of iron quartzite weighing up to 9 metric tons. A conducting channel formed in these rocks after 1 to 10 seconds, and they broke into 3 to 8 pieces after 1 to 3 minutes. Ross $(96)$ has patented a thermal drill (called the Terra Jetter) which cyclically heats and cools rock. As conceived, superheated steam (250 to $500^{\circ} \mathrm{C}$ ) would heat the rock for $3 \mathrm{~min}$ utes and then liquid nitrogen $\left(-134^{\circ} \mathrm{C}\right)$ would be sprayed on the heated rock to thermally shock and pulverize it. Low-pressure steam would be circulated through the drill to remove the pulverized rock from the hole bottom and to reheat the rock. In addition to heating the rock, the high-pressure steam would assist in removing rock by eroding it and by flashing water in pore spaces into high-pressure steam. Ross reports the Terra Jetter should drill granite at 3 to 6 meters per hour and medium-strength rock at 11 meters per hour.

Sarapuu (97) has used the electricdisintegration drill to drill limestone, taconite, and concrete. This drill heats and spalls rock by passing low-frequency electric current (60 cps) into the rock through a sharp bit. The bit is rotated at $90 \mathrm{rpm}$ and air is sprayed on the rock to thermally shock and break it. In 
field tests a 150-kva electricdisintegration drill made

12-centimeter-diameter holes in top soil faster than conventional bits. The heating process dried the top soil and made it easier to remove from the hole bottom. Drilling rates in limestone were low, apparently because of the low resistivity of this rock.

Laboratory tests have shown that microwaves ( 1000 to $3000 \mathrm{MHz} / \mathrm{sec})$ can effectively heat and break rock. Microwaves produce dielectric heating, which is proportional to the frequency of the field. This technique could be used for drilling wells. Steude $1(98)$ used two magnatrons $(2.5 \mathrm{~kW})$ operating at $2400 \mathrm{MHz} / \mathrm{sec}$ to spall sandstone and slate. Thin spalls began to flake off the sandstone surface after 20 to 120 seconds, and the rock was broken after 3 to 10 minutes. Cracking sounds emanated from these rocks prior to the appearance of fractures in the rocks. In some tests, spalls were explosively thrown off the rock surface.

of the thermal spalling techniques, jet piercing appears most promising for forming deep holes since it has seen commercial use in the mining industry. Each of the first two spalling methods discussed above appears to be somewhat restricted by the need for injecting explosive and corrosive materials deep within a long shaft. The other spalling methods discussed suffer from the lack of testing in "hole like" geometries and from physical restrictions which appear to make focusing for "hole like" cases difficult.
Chemical Drills. Chemical drills use highly reactive chemicals such as fluorine to drill rock at high rates. These drills have successfully drilled sandstone, limestone, and granite in laboratory tests. They have limited potential because of the difficulty in handling large quantities of highly reactive chemicals and because of the high cost of these chemicals.

Novel Mechanical Drills. Novel mechanical drills are those which remove rock by mechanically induced stresses. Energy sources for these drills are not necessarily mechanical since explosive, erosion, and spark drills fall in this classification. These drills induce mechanical stresses in the rock by impact, erosion, and abrasion. When these stresses exceed the tensile or shear strength of the rock, the rock fails in a brittle or plastic manner.

An explosive drill which shows promise of providing a method to drill either very deep holes and/ or drill into hot environments has been developed and extensively tested by the Russians. (99) This drill pumps explosive capsules within a drilling mud slurry to the hole bottom. Each capsule is finned and contains two nonexplosive liquids separated by an impermeable membrane. As the capsule passes through a constriction near the bottom of the drill pipe, the membrane is broken, and the liquids mix to form an explosive mixture. Near the hole bottom, the fins actuate a percussion pin which strikes a detonator that initiates the explosion. The chips and 
rubble are carried out of the hole by the drilling mud.

In numerous Soviet field tests, explosive drills have drilled over 3000 meters of 25- to 40-centimeterdiameter holes in oil wells ranging in depth to 4000 meters. Drilling rates of 2.5 to 11 meters per hour have been achieved in limestone and dolomite in these tests. The explosive drills have drilled hard rocks such as hard quartzite or chert at higher overall drilling rates than rotary drills. Rates of 15 meters per hour have been obtained.

Waste disposal concepts consider areas of high rock strength which pose problems using conventional drilling methods. Rock strength has less effect on explosive drilling rates than on rotary-drilling rates. Holes have been drilled in granite and concrete at equal rates using explosive drills even though the granite was seven times stronger. Work on optimization of explosion rate is also reported.

The turbine drill(i00) has been extensively tested in oil wells. A single-stage turbine is used to rotate a diamond-faced cutter wheel at speeds of 5,000 to $10,000 \mathrm{rpm}$. The drill pipe is rotated at 30 to $75 \mathrm{rpm}$, producing a hemispherical hole bottom. Part of the thrust applied to this drill is transmitted to the springloaded cutter wheel, and part is transmitted to the rock through diamond reamers at the bottom of the drill. Several turbine drills were field tested from 1953 to 1956. One serious limitation of this turbine drill is that single-stage turbines are inherently inefficient, and only
10 to 20 percent of the hydraulic power is transmitted to the cutter wheel as mechanical power. Work is currently inactive on this drill, and no commercial tools are available. The method has potential for deep hole application since the drill does not require a rotating shaft at the surface.

Carter $0 i 1$ Company (101) developed a pellet drill. This drill breaks rock by impacting it with steel pellets which are recirculated through the bit. Following impact, the pellets are lifted by the rising fluid to an opening near the top of the drill where they reenter the bit. "Gauge-feeler" feet at the bottom of the drill maintain proper standoff distance between the bit and the rock. This bit is rotated to expose the rock under these feet. A 23-centimeter-diameter pellet drill penetrated hard quartzite at 15 centimeters per hour, 1 imestone at 1.2 meters per hour, and marble at 2.3 meters per hour. Pellet wear was noticeable only in quartzite, where a 200-kilogram charge lost 5.5 kilograms of steel during a 3.5-hour drilling test. In tests, pellet drills demonstrated they can drill even the hardest rocks; but the drilling rates were low due to low power output.

Howe ${ }^{(102)}$ has proposed the continuous penetrator. A high thrust would continuously push the penetrator through the rock, crushing the rock ahead of it and pushing it aside. Since no bit is used, it would eliminate pulling drill pipe to change worn bits. It would also eliminate the need for circulating mud to remove 
cuttings from the well. The thrust would be applied by drill collars, by impact loads, or by wall anchors that grip the borehole walls and hydraulically load the penetrator. Data from impact tests indicate that thrusts of 25 to 140 metric tons would be required to push a 20-centimeter-diameter penetrator through an average-strength sedimentary rock. The high thrust makes the continuous penetrator impractical except for drilling very weak rocks. 0strovskij(99) has proposed using implosions to drill. These drills would produce implosions by pumping hermetically sealed capsules to the holes bottom and breaking them against the rock. The high hydrostatic pressure existing in oil wells would produce intense implosions. Thus far, the concept has been untested.

U1trasonic drills (103) are used commercially for drilling hard materials such as diamonds and ceramics and can be used to drill rock. These dril1s use magnetrostrictive or electrostrictive cores to vibrate emitters at frequencies of 20 to.

$30 \mathrm{kHz} / \mathrm{sec}$. These ultrasonic vibrators are only 40 to 50 percent efficient, so it is necessary to circulate water to remove the excess heat. U1trasonic drills remove rock by cavitation and abrasion. Energy transmitted to the water by the vibrating emitter forms "cavities," or bubbles, in the water; the cavities impact and crush the rock.

Spark, or electrohydraulic dri11s (104) use high-energy sparks to break and remove rock from the hole. sparks, which last from 1 to 50 micro- seconds, are produced by high-voltage capacitors charged to 30 to $70 \mathrm{kilo-}$ volts. The capacitors are fired from 1 to 10 times per second, producing pressure pulses in excess of 6900 atmospheres. Spark drills can produce higher power outputs than rotary drills. For example, a 4-microfarad condenser (70 kilovolt) firing 10 sparks per second produces a power output of 100 kilowatts. This is much higher than the 15 to 400 kilowatts which oil-field rotary drills using roller or drag bits can transmit to rock. Yutkin(104) developed the radial spark dril1. This drill fires sparks from a rotating center electrode to stationary electrodes located around the periphery of the drill. Drilling rates in 4-to 5 -centimeter-diameter holes equaled 18 centimeters per hour in diabase, 60 centimeters per hour in marble and 300 centimeters per hour in shale. This drill fired two sparks per second ( 25 to 30 kilovolts, 0.1 to 0.2 microfarad), producing a power output of 90 to 130 watts.

Erosion drills using high-pressure water jets can drill hard rocks at high rates, provided a threshold pressure drop is exceeded across the nozzles. This threshold pressure, which is a function of rock strength and hydrostatic pressure in the well bore, ranges from less than 140 atmospheres for weak materials such as coal to over 1400 atmospheres for hard rocks such as granite or basalt.

Zelenin used a four-nozzle erosion drill (990 atmospheres) to drill an 8-centimeter.diameter hole in granite at 9.1 meters per hour. Zelenin also traversed blocks of rock with water 
jets (990 atmospheres) at a speed of 0.9 meters per hour, cutting slots 3 to 5 millimeters wide and ranging in depth from 1.8 centimeter in granite to 16 centimeters in 1 imestone.

\subsubsection{Cavity Forming}

Cavities or tunnels can be formed by four basic methods: 1) conventional face drilling, blasting, and mucking (rubble removal); 2) horizontal rotary drilling with a tunnel boring machine; 3) blasting with high. yield explosives; and 4) solution mining in suitable rock. Each has different requirements for access and different ranges of applicability.

In conventional mining, small holes (up to several centimeters in diameter) are drilled several meters into the face to be removed. Explosive charges are placed in the holes and detonated. The rubble is then loaded onto conveyors or into mining cars and transported to the surface. This technique requires manned access, and therefore the necessary 1 ife support systems must be provided. This includes ventilation, lighting, and service facilities. Temperature control facilities would probably be required at depths over 1,500 meters, although manned operations exist without temperature control at depths to 3,000 meters.

The size of the access from the earth's surface frequently depends upon the amount of cavity forming or tunneling to be done. For removal of large amounts of material a large access is needed to allow the use of large equipment having high material removal rates. Cavities of
56,000 cubic meters have been mined through a 110-centimeter cased drill shaft. (105)

Horizontal rotary drilling has been used mostly for near surface tunnel boring; however its use in deep cavity formation is feasible. The principal feature limiting its use at this time is the significant size of the machines. A large access shaft is needed to introduce pieces of the machine into the mine for in-mine assembly. Once the equipment is in place, the cavity is formed by rotating the large drilling bit, continuously loading rubble onto mine cars or conveyors, and removing it with a lift at the mine shaft. For certain rock types, this technique may be used to form cavities more economically than use of more conventional mining tecniques. Tunnels up to at least 7 meters in diameter have been made using horizontal rotary drilling.(105) This technique also requires manned access and is subject to the resultant need for the 1 ife support system previously discussed.

Blasting with sufficiently highyield explosives to irreversibly compact and 1 ift overburden may also be used to form a cavity. One advantage of this type cavity is that it can be made at the bottom of drill holes too small and too deep for manned access. In most materials the resultant cavity is full of rubble and has a 30 to 50 percent void fraction. The explosives may be either conventional chemical explosives or plowshare explosives. 
Chemical explosives are not normally used for this type of cavity forming because the volume needed for placement of the explosives is 20 to 50 percent of that ultimately desired. (106) stepping up to the desired volume by a series of progressively larger explosions is a possibility, but may not be practical.

plowshare explosives avoid the problem of placement volume. However, they may introduce problems of possible radiation leakage during the forming stage. The smallest size, probably about 5 kilotons of equivalent TNT, is also quite large for a pilot plant test, and the nonlinearity in cost per explosion size favors larger sizes. Note, however, that the needed explosions are all very small on the plowshare scale and the depths are all very deep in relation to that required to minimize surface motion and damage. In general, a ton of explosives will produce a cubic meter of volume in the range of 5 to 30 kilotons. The cavity height is usually about 4 times the cavity diameter. Cracking is extensive out to at least this same distance. Surface motion may require the cavity be formed before the surface facilities are built.

Solution mining is applicable for rocks which can be conveniently dissolved. Water is a suitable solvent for rocks such as salt and sylvite. Dilute acid may also be used for rock such as limestone, dolomite, gypsum, and anhydrite. This technique can be quite economical, providing the cavity formed is a satisfactory geometry. Conventional experience has been almost totally confined to dissolving salt by water apparently because the use of solvents other than water is generally uneconomical.

Potential problem areas include control of cavity shape during production and detailed information about the interior and walls of the cavities produced. Apparently no cavity has ever been entered primarily because the production and access have been through small holes and the desire for inspection has been low. Cavity shape is claimed to be controlled if the rock formation is homogeneous and uniform in composition. The concentrated working solution also must be disposed of, which can be a major problem for concepts requiring large volumes. Experience has shown that the cavities are sealed to the usual measuring levels of commer cial interest, generally 1 to 5 percent of the inventory. Careful testing would be necessary to prove tightness to better than 1 percent. Two 400-million-cubic meter cavities have been made in salt. (105)

The extent of cavity lining required depends upon the use of the cavity and the type of material in which it is formed. The extent and form of internal support depends upon the material used, the depth of the cavity, and the time it must be kept open. Three types of support are available: 1) natural material can be left behind in the form of pillars or the cavity itself can be a series of tunnels, 2) the cavity can be open with manmade beams and poles (special forms for this are called "sets") inserted for support of the roof, or 3) the roof can be made self-supporting by systems such as that using 
rock bolts (a) and fencing or other lining materials. The type of cavity lining possible is influenced by the need for, extent of, and type of support. Conversely the type of lining utilized may well dictate the supporting system. A multilayer totally sealed lining is mechanically done best in the shape of a sphere or a cylinder with elliptical ends. Thus a support system such as rock bolts must be provided external to the tank, and/or a manmade support sytem must be placed within the tank.

Cavity lining can be in the form of a tank as mentioned above or can be sprayed on layers of concrete and other materials. The interior may then be covered with a steel or plastic lining, if needed. For tunnels, liner plates may be inserted.

In summary, cavities or tunnels that meet requirements identified for the geologic concepts evaluated can be constructed given an adequate engineering design and adequate materials considerations. The formation of stable tunnels and mines has been demonstrated in materials from salt and coal to hard rocks like granite at depths from the surface down to 3,000 meters. (79) solution-mined cavities of large size have been formed in soluble materials.

In all cases, however, the mining and cavity forming experience is based upon short time periods compared to storage/disposal times required by the concepts employing disposal of waste in manmade structures within a geologic formation. If the tunnel or cavity must stay open for greater than about 100 years, engineering beyond present practice is required.

\subsubsection{Borehole Sealing}

Placement of solidified waste canisters in geologic formations, whether placed individually into boreholes or placed as a group in a rock cavity, will result in a penetration of the geologic environment with potential for contact with man's environment. In order to assure the containment of nuclear waste by the geologic environment, these penetrations must be completely sealed in a manner that will afford the same level of integrity as the geologic environment prior to drilling the borehole.

The only positive method to neutralize the boreholes or entrances is to restore the stratum to essentially its original strength, permeability and compatible chemical characteristics. This basis suggests that the complete plugging of the penetrations (boreholes) throughout their entire length should be considered.

Setting reliable plugs in the boreholes is difficult. General experience in plugging gas and oil wells with various cements and clays to seal off water formations and to fix well casings in place indicates that these plugs may be reliable from only a few years (about 10) up to about 100 years, which is as long as industry has been interested. With proper

a. Long bolts are inserted and cemented into holes in the ceiling and walls to provide support of the cavity surface. 
care during installation the seals may be suitable for longer periods of time. Therefore, with today's plugging technology little confidence can be placed in these plugs for more than 100 years. A problem that has been encountered during borehole plugging is the failure of the cement to completely set when plugging is not carried out properly.

Phillips Petroleum Company successfully plugged a 7,700-meter wel1, which in 1959 was the world's deepest we11. The bottomhole temperature was $157^{\circ} \mathrm{C}$. (107)

A good knowledge of the borehole conditions is required for plugging operations. This includes well temperature and drilling mud characteristics. The temperature effects will control the chemical reaction and the resulting characteristics of the cement. Cement slurries are subjected to progressively higher temperatures from mixing to pumping into the hole and final cement curing. The cements must be able to withstand the temperature encountered during pumping and the static temperature after the hole is filled. These temperatures will affect the ultimate cure of the cement.

The quality of the plug is also in$f l u e n c e d$ by the nature of the mud used in the drilling operation. This mud lines the walls of the formation and will likely weaken the bonding strength of the cement to the formation.

Therefore, it is essential to achieve maximum removal of all the circulatable mud before plugging begins. This cleanout will help produce a stronger bond between the cement and the rock formations. Example methods to reduce the mud problem include thinning the mud with water, jet blasting cement against the wall, preflushing with water before cementing, using cements not affected by the mud, and use of excess cement for the scouring action of the cement itself.

The plugging techniques used for sealing oil and gas wells are generally specified by the state regulatory bodies who must approve placement of the plugs. The normal practice of plugging is to place a minimum-cost plug that will be acceptable to the state regulatory body. Usually the placement of rotary mud between Portland cement plugs is required, and, as such, mud becomes volumetrically the most important plugging material. Mud helps inhibit or prevent movement of water from one porous zone into another porous zone of lower pressure. Probably the most important common conventional plugging material is therefore mud.

There are two broad classifications of hole plugging: 1) plugging of holes immediately upon completion of the hole while the drilling tools are still on location and 2) the reentry and plugging or replugging of old boreholes. The industry-accepted practice for plugging new boreholes involves cleaning out the hole and pumping a cement slurry down the well. Generally an inner casing, commonly the drill pipe, is used for filling the borehole with cement. As the cement is placed in the hole, the inner casing or drill pipe is removed as cementing proceeds, since in time the casing may corrode away, allowing a path to man's environment. It is 
still common in the oil industry to leave all or part of the casing in the hole. Most states require that casings opposite fresh water zones be left in place when the borehole is plugged. Also, removal of casings is very expensive. Laboratory tests have shown that bonding of cement to a rock formation for a seal is considerably improved when cements are used which expand when they cure. (108) The permeability and pressures of expanding cements are generally equivalent to standard Portland cements. The threshold pressures for expanding cements are generally greater than 68 atmospheres.

Expansion of the cement can be increased by addition of expansive aids such as sodium sulfate, sodium chloride, pozzolan (a naturally occurring siliceous or siliceous and aluminous material) or combinations of these to basic portland cement.

Laboratory tests have been conducted on several selected cements and clay-sand mixtures to plug boreholes in salt formations. (109) During initial tests two types of expanding cements were used, including Type $S$ expanding cement from the Ideal Portland Cement Company and Type III Stress-Ex cement from Portland, Colorado. Standard Portland cement (Type I) was used for comparison.

Clay-sand mixtures have been tested for water permeability. (109) clays expand as water is absorbed, thereby reducing permeability. Clays also have much lower solubilities than certain original hole materials such as 1 imestone, gypsum, etc. Pre1 iminary results of these tests, including those for cements, are shown in Table 4.17.

The data show that both Type $S$ and Type II have lower water penetration rates than the standard Portland cement. Type III Stress-Ex appeared to be extremely impermeable, since in three out of four tests no water

TABLE 4.17. Water Penetration through Cement and Clay-Sand Plugs at Pressure of 6.8 Atmospheres (110)

\begin{tabular}{|c|c|c|c|c|c|}
\hline Plug Type & $\begin{array}{l}\text { Curing } \\
\text { (days) } \\
\end{array}$ & & $\begin{array}{c}\text { Flow Rate } \\
\mathrm{ml} / \mathrm{min} \\
\end{array}$ & $\begin{array}{l}\text { Area } \\
\mathrm{cm} 2 \\
\end{array}$ & $\begin{array}{c}\text { Penetration } \\
\mathrm{mm} / \mathrm{min} \\
\end{array}$ \\
\hline Type I Portland & $\begin{array}{r}5 \\
7 \\
19\end{array}$ & & $\begin{array}{l}0.256 \\
0.035 \\
0.006\end{array}$ & $\begin{array}{l}7.54 \\
7.54 \\
7.54\end{array}$ & $\begin{array}{l}0.34 \\
0.05 \\
0.008\end{array}$ \\
\hline Type II I & 5 & No & flow for 24 hrs & -- & --- \\
\hline Type $S$ Expanding & $\begin{array}{l}5 \\
7\end{array}$ & & $\begin{array}{l}0.032 \\
0.027\end{array}$ & $\begin{array}{l}7.79 \\
7.79\end{array}$ & $\begin{array}{l}0.04 \\
0.03\end{array}$ \\
\hline Cement & 19 & & $<0.001$ & 7.79 & $<0.001$ \\
\hline Stress-Ex & 7 & & 0.02 & --- & --- \\
\hline $10 \%$ C1ay-Sand & $\begin{array}{l}-- \\
--\end{array}$ & & $0 . \overline{0} 0015$ & $\begin{array}{l}5.06 \\
5.06\end{array}$ & $\begin{array}{l}0.0036 \\
0.0003\end{array}$ \\
\hline
\end{tabular}


flowed through the plug after 24 hours and at pressure of 6.8 atmospheres.

The results also indicate that clay-sand plugs may be useful in borehole plugging operations. The penetration rate for the clay-sand mixture, about two orders of magnitude better than Portland cement, is still somewhat higher than the penetration rate for the best expanding cements cured under similar conditions.

More recent laboratory tests have been initiated on Portland cements and specialty sealants. The results of these tests are presented in Table 4.18. Except for El Toro $H$ and Tijeras $C$, which were dropped from consideration due to problems encountered in compressive strength and permeability tests, the remaining cements are considered to have reasonable strengths, permeabilities, and sulfate resistance.

Initial tests on specialty sealants indicate that their usefulness may be $1 \mathrm{imited}$. These sealants and their properties are shown in Table 4.19. Nukem 200, a sodium silicate-silica flour sealant, is not suitable due to high shrinkage. Basolit 600, a sulfate sealant, suffers from two disadvantages: 1) it requires heating to $120^{\circ} \mathrm{C}$ to be poured, and 2) the linear shrinkage is greater than 1 percent when the set material cools from $90^{\circ} \mathrm{C}$ tp $30^{\circ} \mathrm{C}$, which would prevent good bonding. A polyester sealant set with a peroxide catalyst

TABLE 4.18. Portland Cement Characteristics (110)

\begin{tabular}{|c|c|c|c|c|c|c|c|c|c|c|}
\hline $\begin{array}{l}\text { Type } \\
\text { Cement (a) }\end{array}$ & & Brand & & $\frac{\text { Wt } \% \text { of }}{\text { Water }}$ & $\frac{\text { Cement }}{\text { Salt }}$ & $\begin{array}{l}\text { Compr } \\
\text { Streng } \\
\text { T day }\end{array}$ & $\frac{(p s i)}{3 \text { days }}(b)$ & $\begin{array}{c}\text { Permeability } \\
\text { mi } 11 \text { idarcy } \\
\quad \times 10-3\end{array}$ & $\begin{array}{l}\text { Salt } \\
\text { Bond } \\
\mathrm{kg} / \mathrm{cm}^{2}\end{array}$ & $\begin{array}{c}\text { Linear } \\
\text { Expansion } \\
1 \% \text { day }\end{array}$ \\
\hline T- 2 & E1 & Toro 2 & & 46 & $\begin{array}{r}19 \\
101\end{array}$ & $\begin{array}{l}677 \\
172\end{array}$ & $\begin{array}{l}1637 \\
2700\end{array}$ & $\begin{array}{l}<1.0 \\
<1.0\end{array}$ & 17.4 & \\
\hline $\mathrm{Cl}-\mathrm{C}$ & El & Toro 3 & 35 & 56 & $\begin{array}{r}19 \\
113\end{array}$ & $\begin{array}{r}1287 \\
245\end{array}$ & $\begin{array}{l}2637 \\
2856\end{array}$ & $\begin{array}{l}<1.0 \\
<1.0\end{array}$ & 20.2 & \\
\hline$T-5$ & E1 & Toro 5 & 5 & 46 & $\begin{array}{r}19 \\
103\end{array}$ & $\begin{array}{l}830 \\
165\end{array}$ & $\begin{array}{l}1662 \\
2850\end{array}$ & $\begin{array}{l}1.0 \\
2.3\end{array}$ & 18.3 & \\
\hline$T-K$ & $\begin{array}{l}\text { El } \\
\text { Che }\end{array}$ & $\begin{array}{l}\text { Toro } \\
\text { m Comp }\end{array}$ & & 56 & $\begin{array}{r}19 \\
125\end{array}$ & $\begin{array}{l}962 \\
130\end{array}$ & $\begin{array}{l}2156 \\
2500\end{array}$ & $\begin{array}{l}<1.0 \\
<1.0\end{array}$ & 18.8 & \\
\hline $\mathrm{Cl}-\mathrm{H}$ & El & Toro $\mathrm{H}$ & $H$ & 46 & $\begin{array}{l}19 \\
97\end{array}$ & $\begin{array}{r}6 \\
48\end{array}$ & $\begin{array}{l}3187 \\
3275\end{array}$ & $\begin{array}{l}3.4 \\
1.8\end{array}$ & & \\
\hline$C l-C$ & $\mathrm{Tij}$ & jeras C & C & 56 & $\begin{array}{r}19 \\
121\end{array}$ & $\begin{array}{r}1248 \\
17\end{array}$ & $\begin{array}{l}6125 \\
7062\end{array}$ & $\begin{array}{r}5.2 \\
<1.0\end{array}$ & & \\
\hline$T-5$ & $T i j$ & jeras 5 & 5 & 46 & $\begin{array}{r}19 \\
121\end{array}$ & $\begin{array}{l}283 \\
266\end{array}$ & $\begin{array}{l}4712 \\
5125\end{array}$ & $\begin{array}{r}<1.0 \\
2.7\end{array}$ & & $\begin{array}{l}+0.03 \\
+0.07\end{array}$ \\
\hline$T-K$ & $\begin{array}{l}T X 1 \\
\text { Com }\end{array}$ & Chem & & 56 & $\begin{array}{r}19 \\
121\end{array}$ & $\begin{array}{l}505 \\
655\end{array}$ & $\begin{array}{l}3750 \\
4275\end{array}$ & $\begin{array}{c}1.1 \\
0.2 \\
(1 \text { day })\end{array}$ & & $\begin{array}{l}+0.29 \\
+0.33\end{array}$ \\
\hline
\end{tabular}

a. T refers to type cement according to ASTM; $C l$ refers to $c l a s s$ according to API; T-K refers to type $K$ expanding as referred to by $A C l$. 
IABLE 4.19. Specialty Hole Sealant Characteristics (110)

\begin{tabular}{|c|c|c|c|c|c|c|c|}
\hline Seatant & Liquid & Salt & $\operatorname{Temp}_{(\mathrm{o} F)}(a)$ & $\begin{array}{r}\text { Compressive } \begin{array}{r}\text { s } \\
\mathrm{kg} / \mathrm{cm}^{2}\end{array} \\
\mathrm{l} \text { day }\end{array}$ & $\frac{\text { trength }}{3 \text { days }}$ & $\begin{array}{l}\text { Permeability } \\
\text { millidarcy } \\
\quad \times 10-3\end{array}$ & $\begin{array}{c}\text { Linear } \\
\text { Expansion } \\
1 \text { day }\end{array}$ \\
\hline Nukem 200 & $\begin{array}{l}50 \\
40 \\
33 \\
40\end{array}$ & \multicolumn{6}{|c|}{$\begin{array}{l}\text { (Not pourable } \\
\text { Salt - Instant gel) }\end{array}$} \\
\hline $\begin{array}{l}\text { Basolit } \\
\quad 600\end{array}$ & Heat & $\begin{array}{r}0 \\
68\end{array}$ & $\begin{array}{l}250 \\
250\end{array}$ & $\begin{array}{l}485 \\
288\end{array}$ & $\begin{array}{r}534 \\
--\end{array}$ & $0 . \overline{0}$ & $\begin{array}{l}-1.1 \\
-1.0\end{array}$ \\
\hline Epoxy & 100 & $\begin{array}{r}0 \\
70\end{array}$ & $\begin{array}{l}80 \\
80\end{array}$ & $\begin{array}{l}\text { Soft } \\
\text { Soft }\end{array}$ & $\begin{array}{l}439 \\
364\end{array}$ & $\begin{array}{c}1.0 \\
0.01 \\
(3 \text { day })\end{array}$ & $\begin{array}{l}-0.09 \\
+0.01\end{array}$ \\
\hline $\begin{array}{l}\text { Phenol } \\
\text { formal- } \\
\text { dehyde }\end{array}$ & 90 & $\begin{array}{r}0 \\
70\end{array}$ & $\begin{array}{l}80 \\
80\end{array}$ & $\begin{array}{l}\text { Soft } \\
\text { Soft }\end{array}$ & $\begin{array}{l}218 \\
209\end{array}$ & $\begin{array}{l}0.1 \\
0.1\end{array}$ & $\begin{array}{l}-- \\
--\end{array}$ \\
\hline Polyester & -- & $\begin{array}{r}0 \\
69\end{array}$ & $\begin{array}{l}80 \\
80\end{array}$ & $\begin{array}{l}868 \\
434\end{array}$ & $78-$ & $0 . \overline{-}$ & -- \\
\hline $\begin{array}{l}\text { Polyacryl- } \\
\text { amide }\end{array}$ & 60 & $\begin{array}{r}0 \\
64\end{array}$ & $\begin{array}{l}80 \\
80\end{array}$ & $\begin{array}{l}\text { Not tested } \\
\text { Not tested }\end{array}$ & & $\begin{array}{l}0.1 \\
0.1 \\
(3 \text { day })\end{array}$ & -- \\
\hline $\begin{array}{ll}\text { a. } & { }^{\circ} \mathrm{C}=1{ }^{\circ} \\
\text { b. } & \text { psi }=\end{array}$ & $\begin{array}{l}\text { 2) } / 1.8 \\
07 \mathrm{~kg} / \mathrm{c}\end{array}$ & & & & & & \\
\hline
\end{tabular}

proved to be difficult to handle under field conditions and was removed from further consideration. The phenolformaldehyde resin sets by a condensation process which releases water and results in some shrinkage.

Epoxy sealant using an amine catalyst and Dowell Seal Ring are still undergoing tests. (110) The epoxy shows no apparent shrinkage on setting, excellent adhesion to surfaces, and good strength with no water permeability. The Seal Ring (a 35 percent crosslinked polyacrylamide in glycol) is a rubberlike material, so the usual compressive strength and 1 inear expansion tests were not run. Water permeability tests indicate that the material is essentially nonpermeable. The material resists water encroachment pressures of several thousand psi (several hundred atmospheres). Both of these sealants seem quite promising but long-term durability is the major question. (110)

The $150^{\circ} \mathrm{C}$ maximum temperature to be expected at depths up to 4,600 meters has little effect on the strength of cement. The effect of temperature due to geothermal gradients is relatively small for depths up to 9,000 meters. The compressive strengths of cements range from about 2,100 to $3,500 \mathrm{~kg} / \mathrm{cm}^{2}$ when under a confining pressure of 970 atmospheres. (111) These are comparable to the strengths of sedimentary rocks under similar conditions. Thus the strengths of plugging cements under downhole pressure-temperature conditions are at least as good as those 
of sedimentary rock generally found in surrounding formations. The ultimate compressive strengths of rocks rise with increasing depth.

Dowell Company of Tulsa, Oklahoma, under contract to ORNL, has provided an in-depth investigation pertaining to the evaluation of materials and technologies for borehole plugging. A 1 iterature search and demonstration of borehole sealing techniques has been emphasized. Information on sealing of boreholes in salt, gypsum and anhydrite was reviewed. Laboratory tests including compressive strength, permeability, expansion sulfate resistance, and shear bond strength have been made on several cements. Tentative results show that the use of sulfate-resistant Portland cement as the primary sealant and epoxy cement in critical areas should provide a good sealant in salt formations. No published information is yet available on this work.

The cost of plugging or replugging old boreholes by conventional techniques is estimated to be on the same order of magnitude as the dri11ing cost, which ranges from $\$ 10,000$ for a depth of up to 1,500 meters to greater than $\$ 100,000$ per hole for depths up to 6,100 meters. These costs are high because of the problems of locating the old hole, the hazards of re-entry, the possibility of drilling out the old hole and the unknowns about the condition of the hole. The cost of plugging some gas wells was recently reported to be in the range of about $\$ 8,000$ to $\$ 14,000$ for a well about 600 meters deep. $(112,113)$ Routine plugging to state specifications of newly drilled oil test holes with the drilling tools still on location can probably be done for less than one-tenth the cost of drilling the hole. (114)

Borehole plugging must be critically evaluated before the relative merits of the various possible methods of geologic disposal can be realized. Borehole plugging may be the limiting factor for a disposal concept. Geologic disposal of highlevel radioactive waste implies containment for time periods up to one million years; hence, borehole seals must be maintained for the same time frame. Clay minerals are among the best plugging materials for preventing fluid flow into otherwise permeable rocks while remaining stable in the upper earth's crust for long periods of time. Portland cement, presently the second most commonly used material, in some cases remained in excellent condition for time periods of at least 2000 years.

\subsubsection{Heat Removal Relative to Waste Disposal}

Heat transfer analys is of buried radioactive waste is required to determine the amount of external cooling needed to maintain design structural temperatures or, if no cooling is provided, to determine the $1 \mathrm{imit}$ on the heat that can be conducted into the surrounding geologic formation or the amount of melting that will occur around the repository. Determination of the thermal stresses in the surrounding rock and the heat load on the surface environment also 
requires information obtained from the heat transfer analysis.

4.0.6.1 The Nature of the Heat Transfer Problem

If a concentrated radioactive heat source is placed in a fluid cooling medium such as flowing air or water, it will typically reach a steady-state temperature within a few hours with its center far below its melting point. As time passes, the center temperature will decrease as the rate of heat generation decreases.

In disposal of radioactive waste in geologic formation, when an active means such as forced air convection, natural air convection, or forced and natural convection water cooling is present to remove heat from the waste to a heat sink such as the atmosphere, a lake or a river, the temperature of the waste soon reaches a steady-state value below its melting point. When these means are not present or are interrupted, conduction through the surrounding rock or soil itself is the only means to remove heat. The heat must be transferred into the geologic formation, where it is stored and dissipated. Terrestrial materials in general are poor heat conductors and act to some extent as insulators.

The time-temperature relationship of a radioactive heat source perfectly insulated from its surroundings is a function of the rate of radioactive heating per unit volume of source, the thermal properties of the source, and the rate of decay of the radionuclide involved. For example, assuming a highly radioactive source such as pure strontium-go flu- oride, the temperature will increase in an approximately linear fashion, reaching the melting point in a few minutes. The source will remain at the melting point for a few hours, rise in temperature to the boiling point in a few more hours, and eventually increase in internal pressure until it explodes. On the other hand, if the source is diluted manyfold with non-heat-generating material (such as the case with bulk waste), the temperature of the source may rise only a few degrees, first linearly with time and then more slowly at times approaching the 30-year half-life of strontium-90. Eventually after many half-lives, the temperature will remain constant as nearly all of the strontium-90 is converted to stable zirconium-90. Of course, in an imperfect insulator such as a geologic formation, the temperature will rise until the rate of heat generation equals the rate of heat dissipation and then will decrease as the source decays.

In geological formations such as shale, basalt, granite or salt, the magnitude and time of occurrence of the maximum temperature of the source are highly dependent upon the source geometry. Heat transfer analysis in underground disposal or storage of radioactive waste is primarily concerned with estimation of transient conductive heat transfer associated with exponentially decaying heat sources to determine the maximum source temperature and the temperature of the surrounding formation as a function of source geometry and the thermal properties of the geologic formation. 
The geometries used to develop the results presented here are the point source, the spherical shell source, the long line source, and the finite array of short line sources. Analytical solutions for each geometry source, assuming an infinite geologic formation with constant thermal properties, were developed to provide rapid design data for concept evaluation. The effect of mixtures of radionuclides with differing half-lives and the effect of nearness to the earth's surface are also included by using the method of superposition.

Each geometry has a special use. The spherical shell source can be applied to a mined cavity with a cubical, short cylindrical or spherical geometry. It has been modified to include extended filling time periods and melting of the surrounding rock to enlarge the cavity. The point source is useful in estimating temperatures at appreciable distances from a source. A cavity tends to become spherical as it melts and the temperature field becomes spherical around any finite source as the distance from it increases.

The long line source is applicable to tunnels, as an asymptote for the short line source, and to the initial stages of the deep hole concept. systems of tunnels have been simulated by superposition. The short line source is directly applicable to the wall of a direct-buried canister itself or to the region immediately surrounding $i t$. The short line is a satisfactory model for the more complex short cylindrical canister because the thermal capacity of the canister is small compared with the surrounding rock and at the time the maximum temperature occurs the resis tance to heat flow is dispersed over a large volume without being concentrated near the canister wall. Finite arrays of non-identical canisters or clusters of canisters oriented in various ways with respect to each other and toward grade can be built up by superposition to give the effects of spacing and canister diameter on the local temperatures.

It is time consuming to build up arrays larger than about 50 to 100 canisters by superposition. Another approach, first used by ORNL, (115) is to assume a bounded unit cell around a single buried canister of an array of identical canisters. The analytical solution for this problem is somewhat complex and is often unstable. It is used here only where no other approximation will work.

The plane source and the disc source give the average rock temperature in the plane of distributed heat sources such as arrays of canisters, the allowable heat generation per unit area (e.g., per hectare) of the array, and the heat flux into and temperature gradients in surrounding formations. The disc source has been used to estimate the temperature in hydrofractures with two dimensional spreading of the waste.

Each geometry has its own peculiar limitations. The temperature is infinite at the point source and the line source, but it is finite at the plane, disc, and spherical shell sources. If the heat generation rate is constant without radioactive decay, the regions around the point, spherical 
shel1, short line, and disc reach steady-state temperatures, but the temperatures around the long line and the plane sources increase without limit with time.

The example results presented in the following sections are based on the assumption of homogeneous media with temperature independent properties (specific gravity of 2.5 and a specific heat of $0.2 \mathrm{cal} /(\mathrm{g})\left({ }^{\circ} \mathrm{C}\right)$ are assumed as reasonable average values for geologic formations), a single half-life of 30 years (typical of 10-year-old waste), and heat transfer by conduction only. Within the limits discussed, the calculation techniques used to develop these data can be used in rapid evaluations for most potential geologic disposal concepts. For many specific applications, more exact results may require refinement of these study models.

\subsubsection{Arrays of Heat Sources} Whether the waste canisters are arranged vertically or horizontally, if they are equaliy spaced in an infinite array, the gross behavior results in a temperature versus position or distance from the plane of the waste similar to that shown in Figure 4.22. For a power density of $247 \mathrm{~kW} /$ hectare $(100 \mathrm{~kW} / \mathrm{acre})$ in a rock medium with a thermal conductivity of

DISTANCE FROM PLANE, METERS

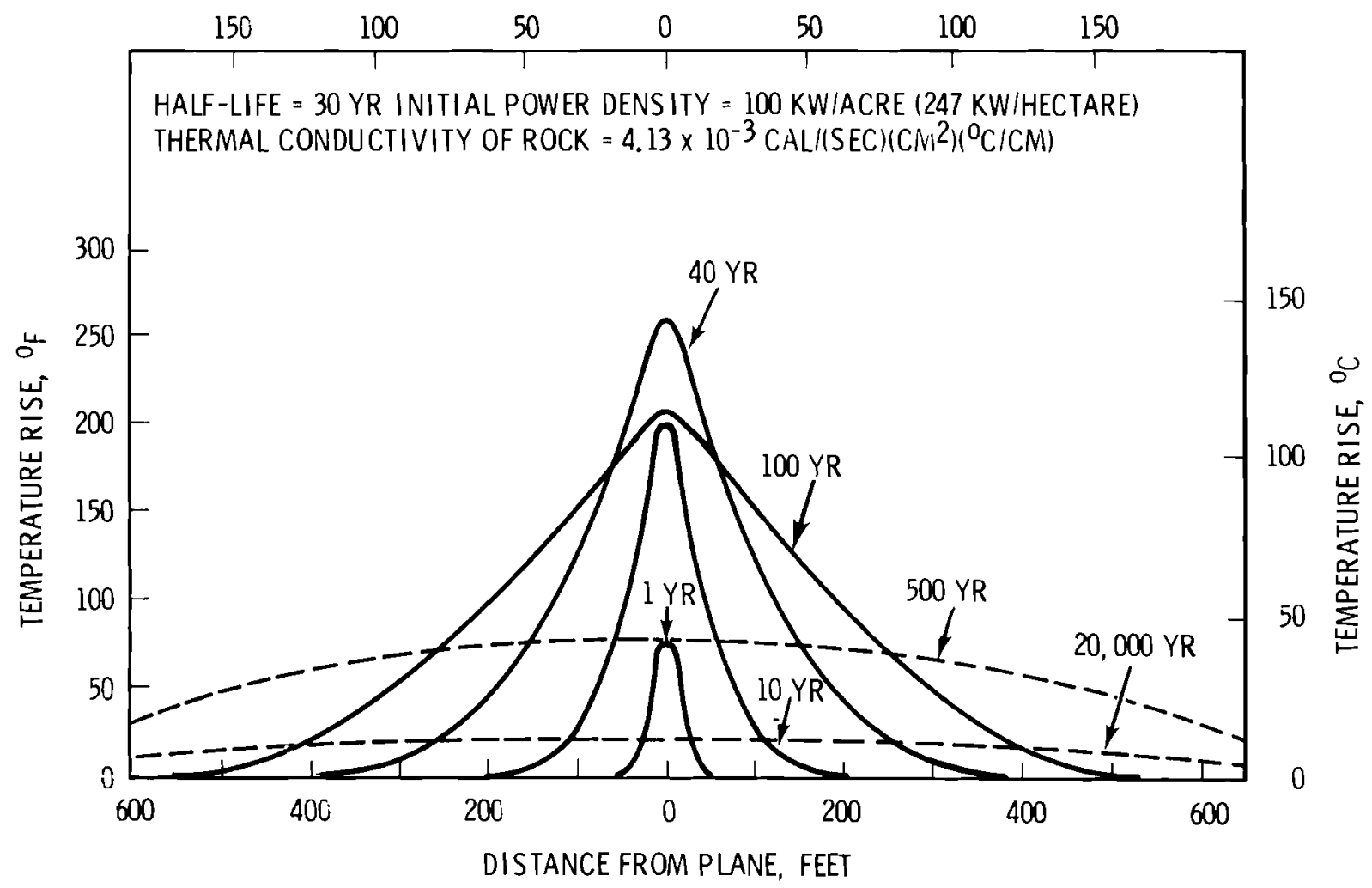

FIGURE 4.22. Transient Temperature Around an Exponentially Decaying Infinite Extent Plane Source 
$4.13 \times 10^{-3} \mathrm{cal} /(\mathrm{sec})\left(\mathrm{cm}^{2}\right)\left({ }^{\circ} \mathrm{C} / \mathrm{cm}\right)$, or $1.0 \mathrm{Btu} / \mathrm{hr}\left(\mathrm{ft}^{2}\right)^{\circ} \mathrm{F} / \mathrm{ft}$, the average temperature rise in the $\mathrm{plane}$ of the array reaches a maximum of $144^{\circ} \mathrm{C}$ in 40 years and decreases thereafter. The effect on the surrounding rock reaches greater and greater distances as the temperature wave expands and subsides. If the array is at a depth of 1525 meters where the average geothermal temperature is $50^{\circ} \mathrm{C}$, the maximum average temperature of the array is $194^{\circ} \mathrm{C}$.

A comparison of the temperature rise for geologic formations with thermal conductivities varying over a tenfold range is given in Figure 4.23. The temperature rise is greater for lower thermal conductivity rock but does not quite vary inversely with the conductivity. For example, with a power density of $274 \mathrm{~kW} / h e c t a r e$, the maximum temperature rises in the $\mathrm{plane}$ of the array are $83^{\circ} \mathrm{C}, 144^{\circ} \mathrm{C}$, and $262^{\circ} \mathrm{C}$ for salt $\left[\mathrm{k}=1.24 \times 10^{-2} \mathrm{cal} /(\mathrm{sec})\left(\mathrm{cm}^{2}\right)\right.$ $\left({ }^{\circ} \mathrm{C} / \mathrm{cm}\right)$ or $\left.3 \mathrm{Btu} / \mathrm{hr}\left(\mathrm{ft}^{2}\right)\left({ }^{\circ} \mathrm{F} / \mathrm{ft}\right)\right]$ crystalline rock $\left[k=4.13 \times 10^{-3}\right]$ and loose sand $\left[k=1.24 \times 10^{-3}\right]$, respectively. The temperature rise is, however, directly proportional to the heat generation rate so that temperature limits resulting in lower power densities can easily be imposed.

The effect of burial depth is shown in Figure 4.24. Generaliy, depths less than 60 meters are required to affect the maximum temperature at the plane of burial. For example, shallow burial at a depth of

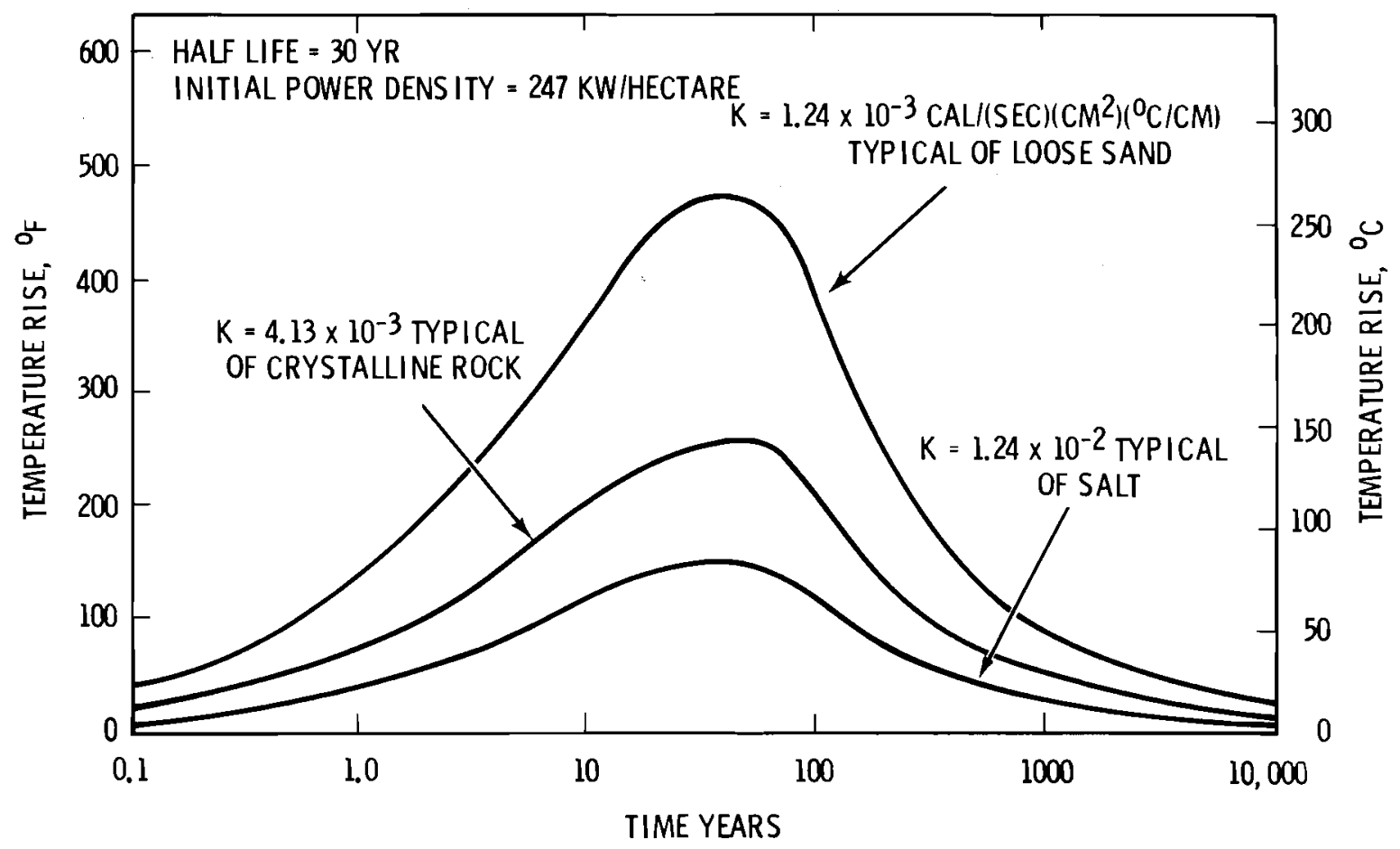

FIGURE 4.23. Transient Temperatures in an Exponentially Decaying Plane Source - Effect of Thermal Conductivity 
DEPTH OF BURIAL BELOW GRADE, METERS

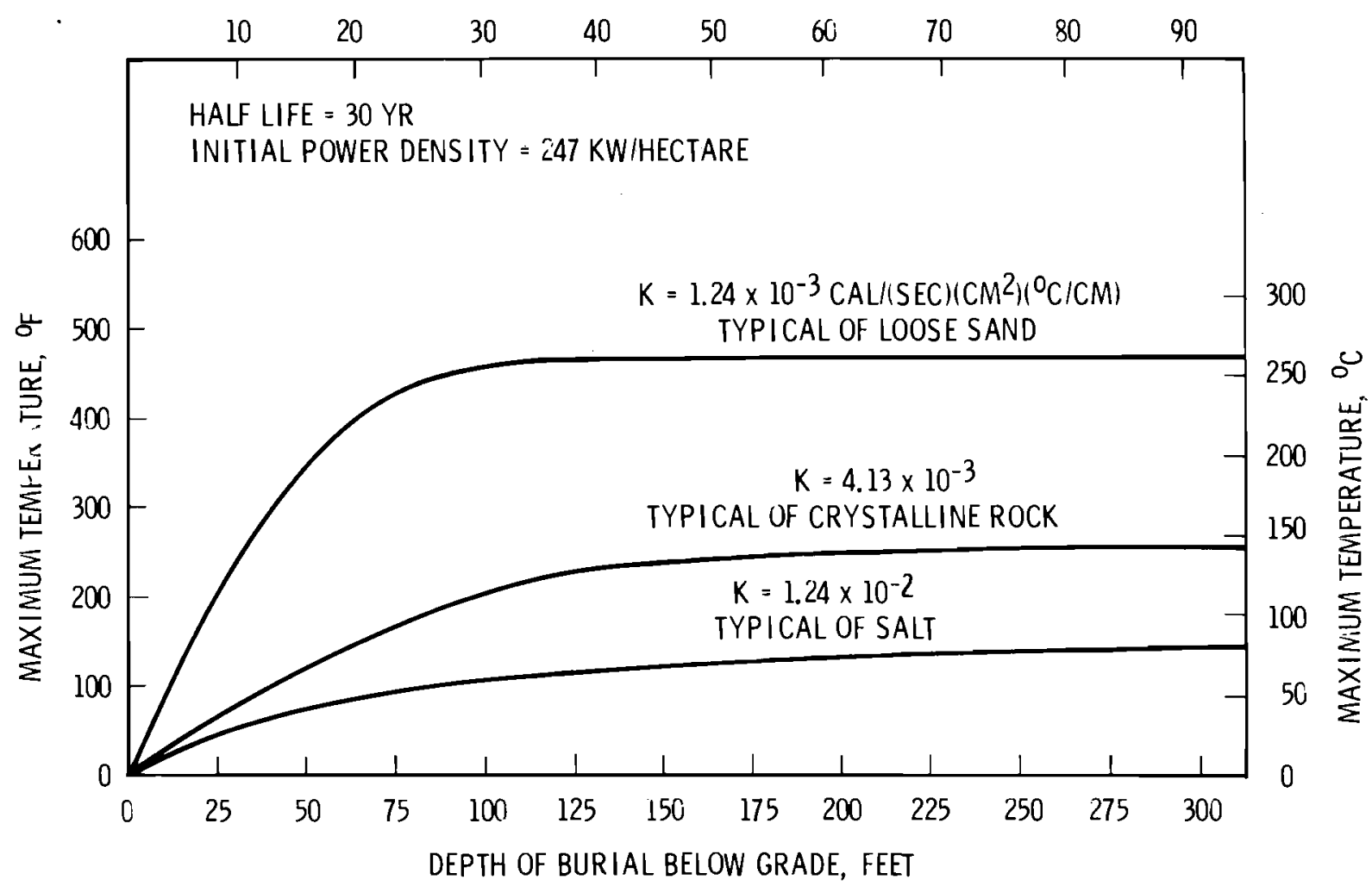

FIGURE 4.24. Effect of Burial Depth on Maximum Temperatures in an Exponentially Decaying Plane Source

30.5 meters reduces the temperature rise from $144^{\circ} \mathrm{C}$ to $132^{\circ} \mathrm{C}$ for a plane source in a rock medium with a thermal conductivity of $4.13 \times 10^{-3}$ $\mathrm{cal} /(\mathrm{sec})\left(\mathrm{cm}^{2}\right)\left({ }^{\circ} \mathrm{C} / \mathrm{cm}\right)$, or $1 \mathrm{Btu} / \mathrm{hr}$ $\left(f t^{2}\right)\left({ }^{\circ} \mathrm{F} / f t\right)$. The effect of burial depth is approximately the same for al1 geometries.

Figure 4.25 shows the effect of the size of the array upon the maximum temperature at its center. If the radius of a disc representing the array gets larger than about 60 meters, there is no effect of size upon the maximum temperature. This size corresponds for example, to a field of 37 vertical cylinders arranged on a triangular pitch with a spacing of

\section{4 meters between neighboring} cylinders.

Even in an array of buried canisters the highest local temperature in the surrounding rock is at the canister wall. This temperature is the sum of two effects: the local temperature rise, which is a strong function of the canister radius, and the temperature rise due to its neighbors, which is independent of canister radius but strongly dependent on spacing between neighbors. When either the rock temperature or the temperature of the canister structural material is $1 \mathrm{imiting,} \mathrm{the} \mathrm{wall}$ temperature is often used as the design basis maximum temperature. If 
RADIUS OF DISC SOURCE, METERS

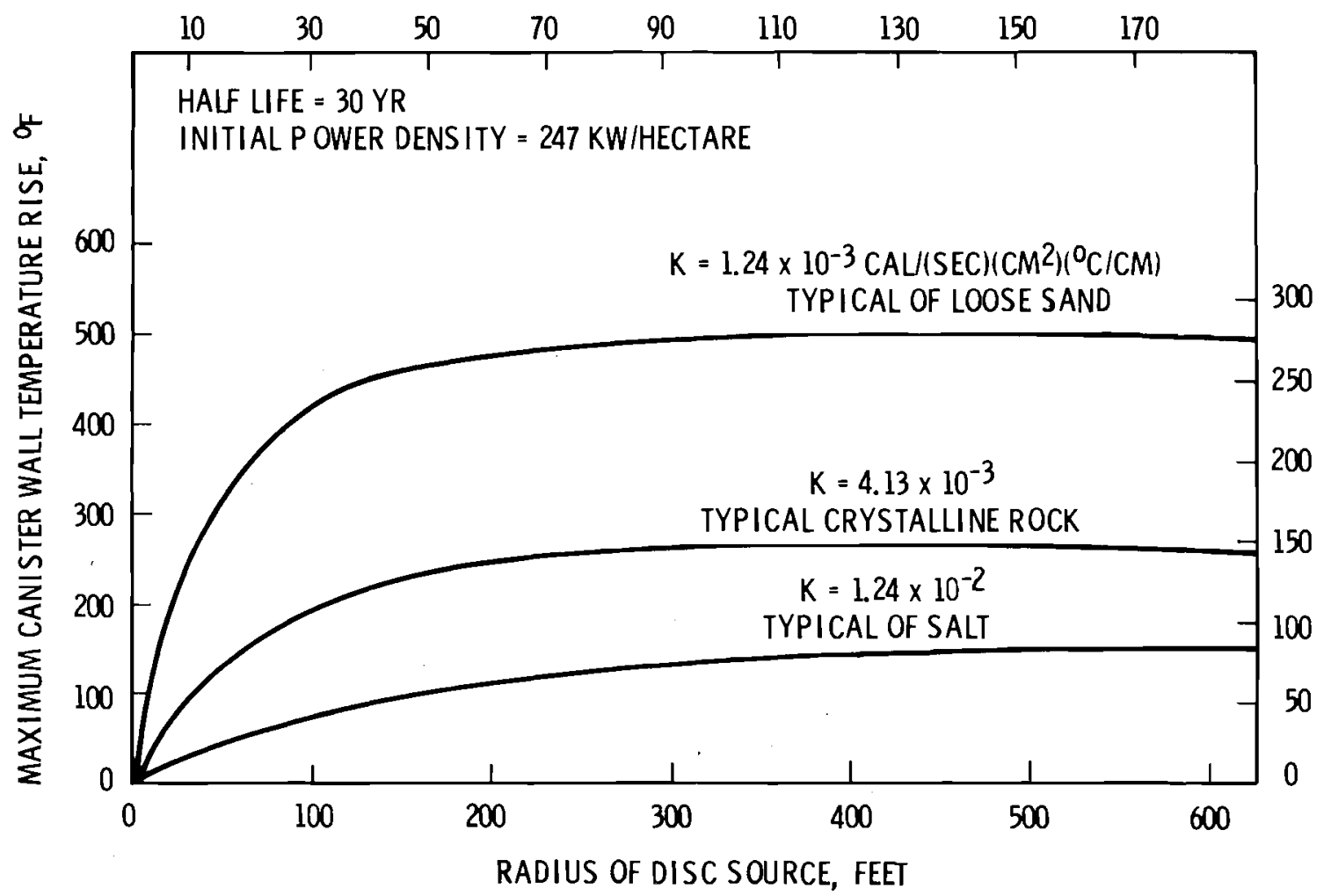

FIGURE 4.25. Effect of Disc Size on Maximum Temperature of an Exponentially Decaying Heat Source

an internal canister condition such as the center-line temperature is limiting, it is sufficient to neglect the internal canister temperature transients and add on a steady-state temperature rise to the canister wall temperature with allowance for slow variation of the heat generation rate with radioactive decay. Nevertheless, additional variables such as waste thermal conductivity and the presence of internal fins, composites or annuli greatly complicate heat transfer considerations in the waste storage/ disposal design when canister centerline temperatures are limiting.

The maximum wall temperature in an array of 3-meter-length cylinders as a function of spacing is given in Figure 4.26 with cylinder radius as parameter. The same information is compared with the average rock temperature in the plane on Figure 4.27 as a function of the power density. The local wall temperature is clearly much higher than the average plane temperature. For a 30-centimeterdiameter canister, Figure 4.28 shows the wall temperature versus the power density as a function of the rock thermal conductivity. With low thermal conductivities the temperature at the wall of a single canister with no neighbors is still much above the design limits of the materials of construction. 
CENTER TO CENTER SPACING, METERS

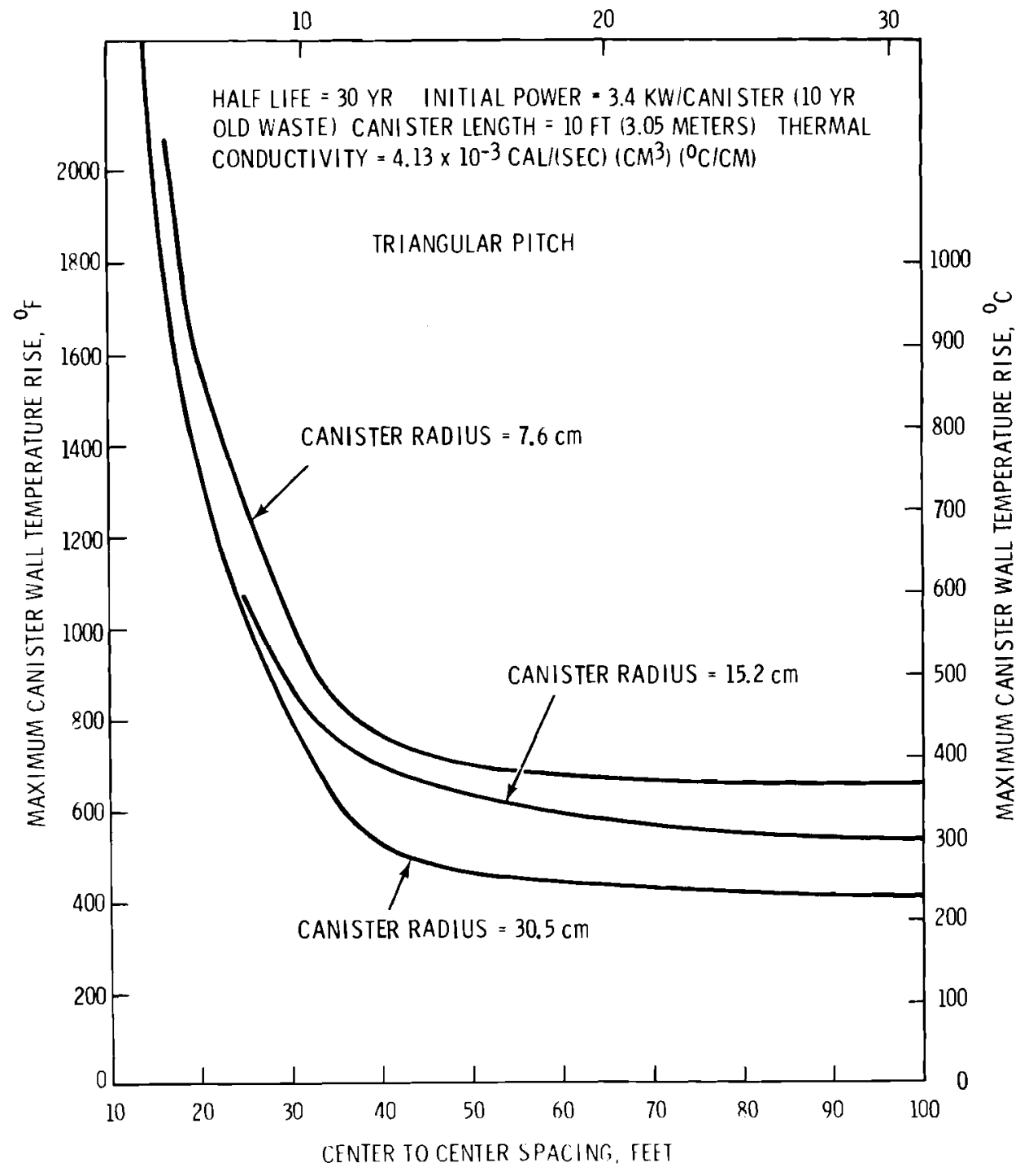

FIGURE 4.26. Effect of Spacing and Canister Radius on Temperature in Arrays of Buried Waste Canisters Containing Exponentially Decaying Heat Sources 
POWER DENSITY, KWIHECTARE

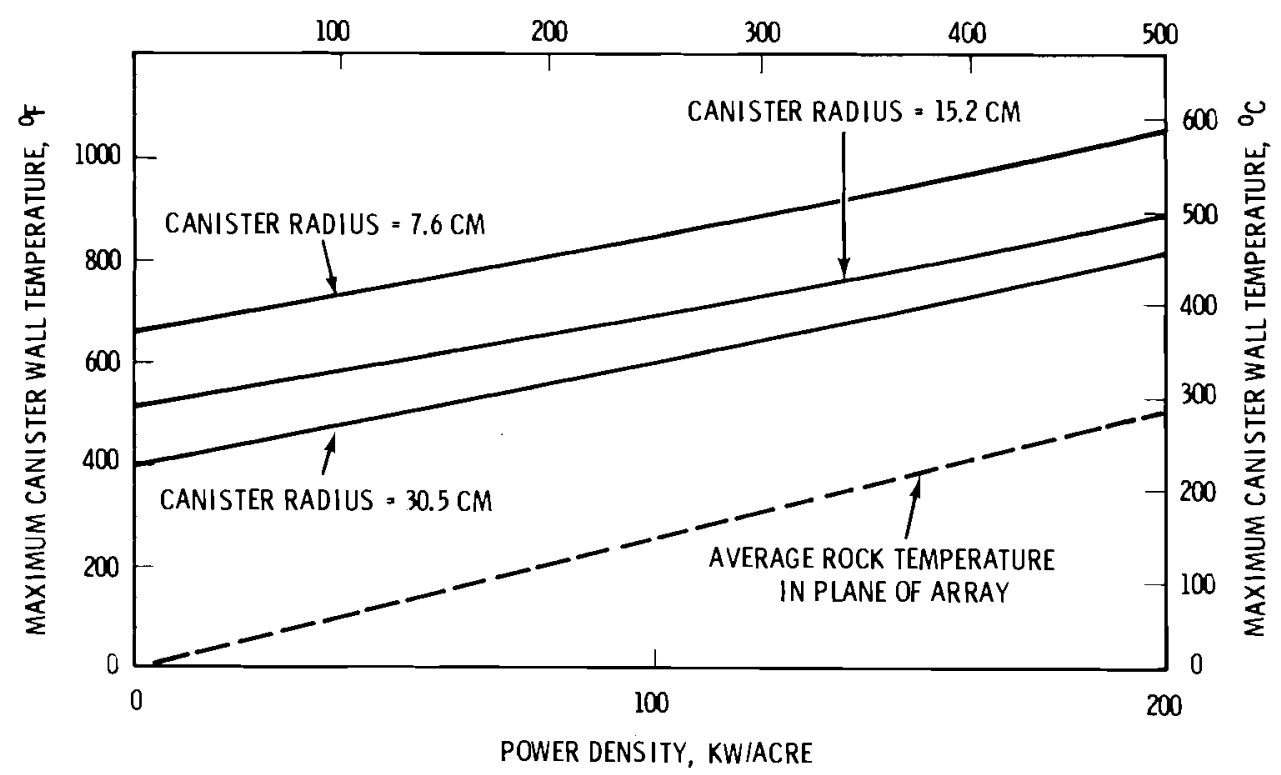

FIGURE 4.27. Effect of Power Density and Canister Radius on Temperature in Arrays of Buried Waste Canisters Containing Exponentially Decaying Heat Source

POWER DENSITY, KW/HECTARE

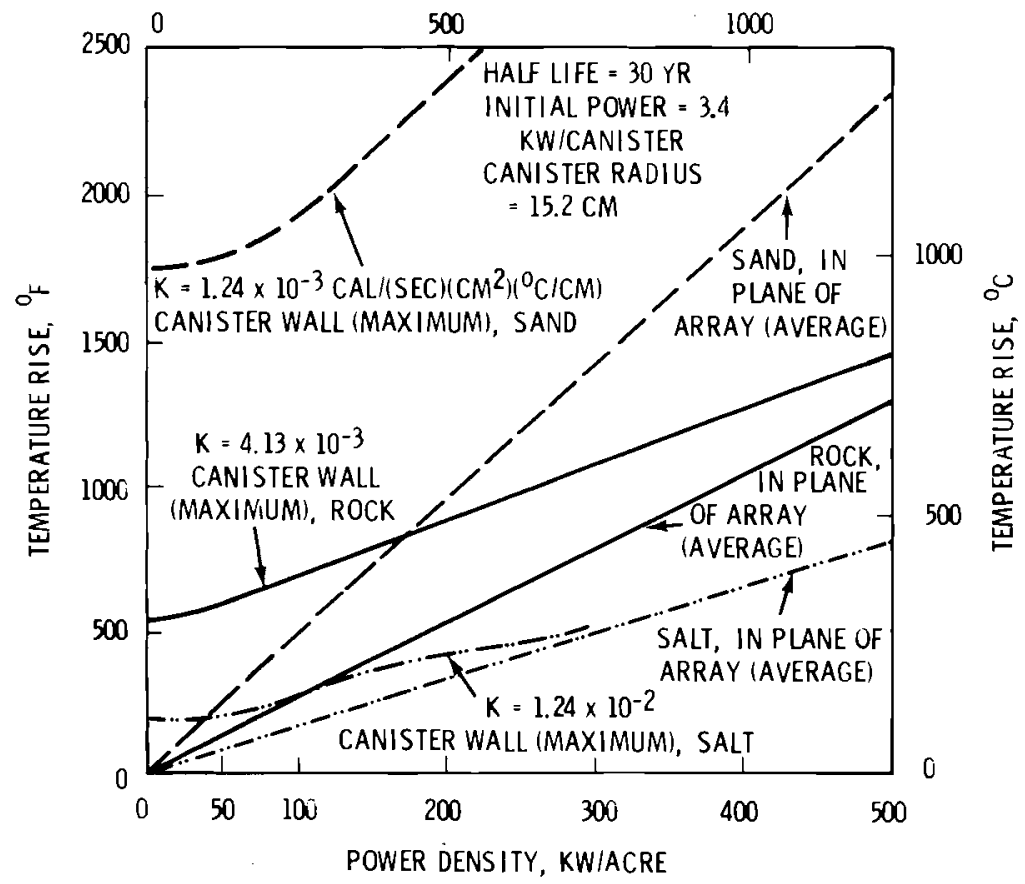

FIGURE 4.28. Effect of Rock Thermal Conductivity and Power Density on Temperature in Arrays of Buried Waste Canisters Containing Exponentially Decaying Heat Sources 
The temperature rise in salt is generally less than in most other geologic materials. But the allowable temperature rise may also be much less in salt. Salt temperatures may be 1 imited to below $260^{\circ} \mathrm{C}$ because of moisture content and plastic flow. Temperatures in some types of dry crystalline rock may be limited only by cracking of the rock due to thermal stress. Allowable temperatures in sand are much higher, but the unconsolidated medium may shift the design limiting factor to the integrity of the canister wall itself, which may be above the crystalline rock temperature limit.

\subsubsection{Single Heat Sources}

The analysis of solitary heat sources is usually associated with intentional melting of the surrounding rock or with analysis of accidents resulting in melting. High temperatures may also be associated with burial of short-cooled waste still containing appreciable quantities of Ru-106, Cs-134, and Ce-144. Figure 4.29 shows the effect of lowering the age of the waste on the temperature of the canister wall. For 10-year-old waste with an initial heat generation rate of $3.4 \mathrm{~kW}$ with 86 percent of the power due only to about 30-year half-1ife radionuclides (sr-90 and Cs-137), the maximum canister wall temperature $r$ ise is $282^{\circ} \mathrm{C}$ at 1.78 years after buria1. The same waste with an age of 5.7 years initially generating $5 \mathrm{~kW}$ of which 65 percent is $\mathrm{Sr}-90$ and $\mathrm{Cs}-137$ reaches a maximum wall temperature

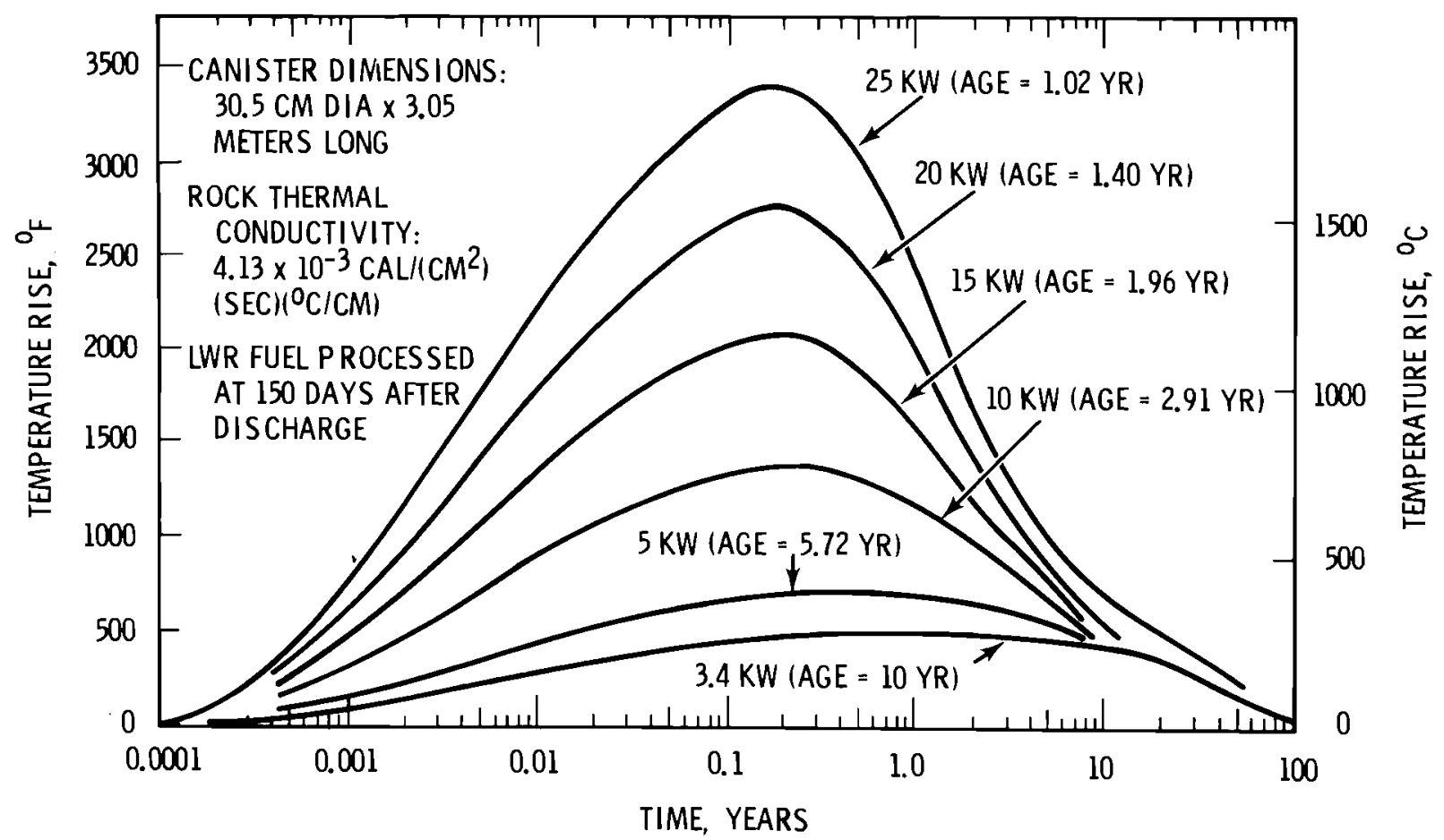

FIGURE 4.29. The Effect of Waste Age on the Maximum Wall Temperature of Single Buried Canisters 
rise of $392^{\circ} \mathrm{C}$. The same waste with an age of 2.9 years generating $10 \mathrm{~kW}$ of which 35 percent is $\mathrm{Sr}-90$ and Cs-137 reaches $742^{\circ} \mathrm{C}$, and waste with an age of 1.96 years generating $15 \mathrm{~kW}$ of which 23 percent is $5 r-90$ and Cs-137 reaches $1153^{\circ} \mathrm{C}$. Thus tripling the heat generation rate by adding short half-life fission products increases the maximum temperature rise by about the same factor.

Lowering the age of the waste or increasing the quantity of heat in the hole results in melting of the surrounding rock, as suggested in one of the deep-hole concepts. As the rock begins to melt, the shape of the pool changes from cylindrical to spherical because temperature is a potential function.

In one mined cavity concept, the aqueous waste is continuously poured into a 10-meter-radius cavity for 25 years and then allowed to heat and melt a pool of rock. Shown in Figure 4.30 are the results of calculations made for spherical pools formed under the conditions given by Lawrence Livermore Laboratory for their nuclear cavity concept. (116) The properties for the three types of geologic formations are given in Table 4.20 along with the calculated mimimum power at 25 years to enlarge the cavity by melting. The maximum size of the molten cavity, occurring

FUEL PROCESSED, METRIC TONS

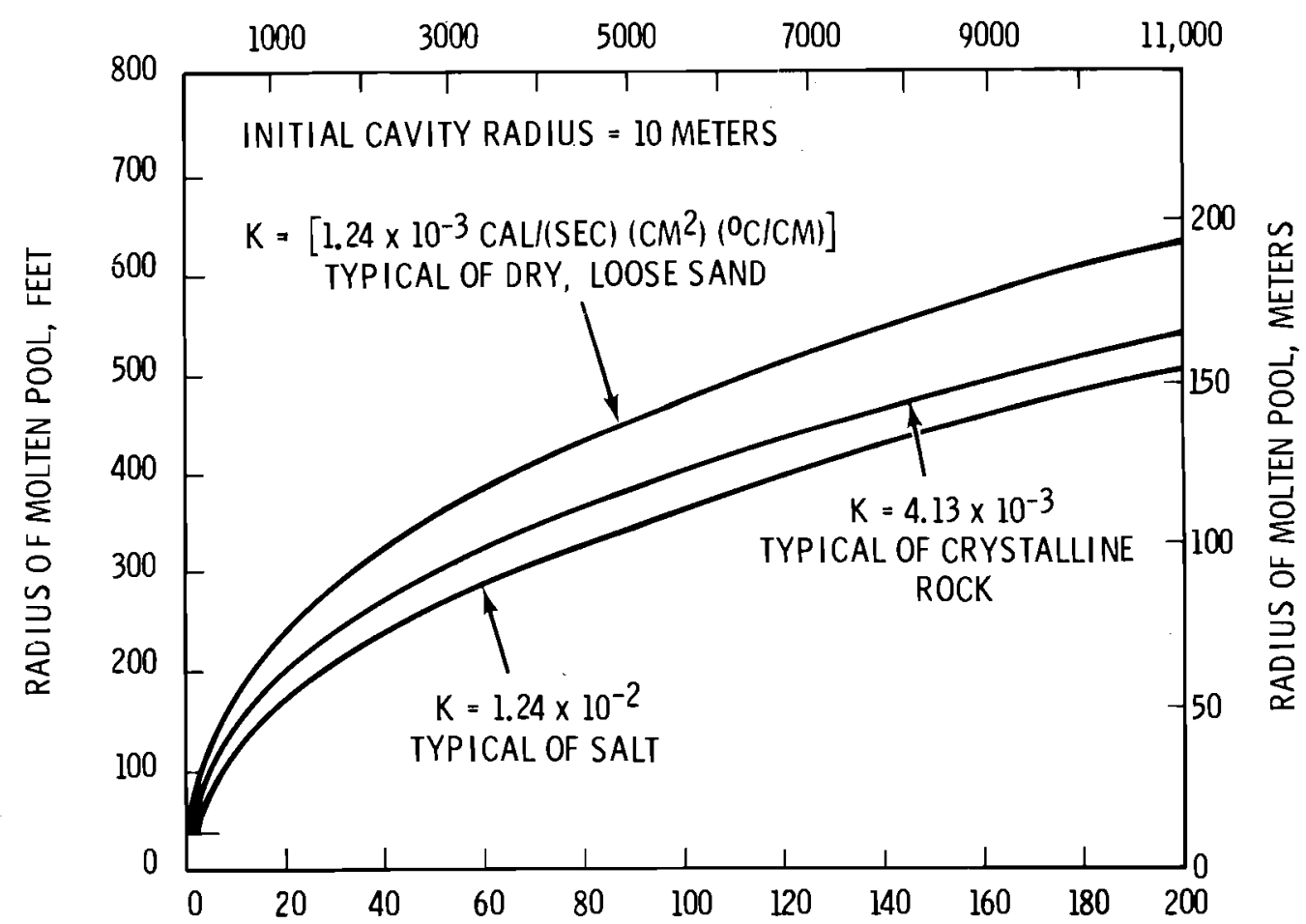

HEAT GENERATION RATE WHEN FILLING IS STOPPED AT 25 YEARS, MEGAWATS

FIGURE 4.30. Size of Molten Pool as a Function of Heat Generation Rate 
TABLE 4.20. Properties Used in Molten Pool

Calculations

\begin{tabular}{|c|c|c|c|c|c|}
\hline & $\begin{array}{l}\text { Thermal Conductivity }(\mathrm{a}) \\
\mathrm{cal} /(\mathrm{sec})\left(\mathrm{cm}^{2}\right)\left({ }^{\circ} \mathrm{C} / \mathrm{cm}\right)\end{array}$ & $\begin{array}{c}\text { Melting } \\
\text { Point, } \\
{ }^{\circ} \mathrm{C} \\
\end{array}$ & $\begin{array}{l}\text { Heat of } \\
\text { Fusion, } \\
\text { cal/g }\end{array}$ & $\begin{array}{l}\text { Specific } \\
\text { Heat, } \\
\mathrm{cal} / \mathrm{g} / \mathrm{cc} \\
\end{array}$ & $\begin{array}{l}\text { Minimum } \\
\text { Power to } \\
\text { Enlarge } \\
\text { Cavity by } \\
\text { Melting, } \\
\text { kW } \\
\end{array}$ \\
\hline $\begin{array}{l}\text { Salt } \\
\text { Crystalline Rock } \\
\text { Loose Sand }\end{array}$ & $\begin{array}{l}1.24 \times 10^{-2} \\
4.13 \times 10^{-3} \\
1.24 \times 10^{-3}\end{array}$ & $\begin{array}{r}808 \\
1100 \\
1100\end{array}$ & $\begin{array}{r}116 \\
80 \\
80\end{array}$ & $\begin{array}{l}0.2 \\
0.2 \\
0.2\end{array}$ & $\begin{array}{r}1300 \\
800 \\
340\end{array}$ \\
\hline
\end{tabular}

a. Arbitrarily selected from within a range of values for each specific material.

at times less than 200 years after filling, is shown as a function of the power at the end of the 25-year filling period. It is apparent that the low thermal conductivity and high heat of fusion of salt is nearly compensated for by the low melting point of salt in lessening the differences in the maximum size of the molten mass for three types of geologic formations.

\subsection{DESCRIPTION OF GEOLOGIC DISPOSAL CONCEPTS}

Ten concepts for disposal of highlevel radioactive waste in geologic formations were considered in this study. The ten concepts are listed with their key operational characteristics in Table 4.21.

In all concepts the final waste form is a solid. Concept 1 is based on the placement of canisters filled with solidified waste in excavations formed by conventional mining techniques. A regular, dispersed storage array is specified to minimize wasterock reactions. Concepts 3 and 4 are also based on underground cavities, but fluid cooling is used to permit a close-packed storage array while minimizing reactions. In Concept 7 a dispersed storage array is attained from the surface via a matrix of drilled holes.

Concept 2, also a mined cavity concept, is based on fluid cooling for an interim period, but, as indicated in Table 4.21, after a time canister cooling is stopped and the waste permitted to react with the host rock. Waste-rock melting can either be permitted or not permitted for concept 8 , which is based on placing solid waste in a deep drilled hole.

For Concepts 5,6 , and 9 the selfgenerated heat within the liquid waste is used to dry and melt the waste and some of the surrounding rock which, when cooled, forms a solid waste-rock matrix. In concept 10, the liquid waste is incorporated within a self-curing cement. Because of the large volumes generated and the potential hazards of shipping aqueous high-level waste, the liquid emplacement concepts require locating the disposal site at 
TABLE 4.21. Characteristics of Geologic Disposal Concepts

\begin{tabular}{|c|c|c|c|c|}
\hline Concept & Type of Cavity & $\begin{array}{l}\text { Waste Form } \\
\text { at Time of } \\
\text { Emplacement } \\
\end{array}$ & $\begin{array}{l}\text { Fluid } \\
\text { Cooling } \\
\end{array}$ & $\begin{array}{r}\text { Waste-Rock } \\
\text { Reactions } \\
\end{array}$ \\
\hline 1 & Mined & Solid & No & No \\
\hline 2 & Mined & Solid & Water & Me $1 \mathrm{t}$ \\
\hline 3 & Mined (a) & Solid & $\operatorname{Air}(c)$ & No \\
\hline 4 & Mined (a) & Solid & Water $(c)$ & No \\
\hline 5 & Mined & Liquid (b) & No & Melt \\
\hline 6 & Exploded & Liquid ${ }^{(b)}$ & No & $\mathrm{Melt}$ \\
\hline 7 & $\begin{array}{l}\text { Matrix of } \\
\text { Drilled Holes }\end{array}$ & Solid & No & No \\
\hline 8 & Deep Hole & Solid & No & No/Mel $t^{(d)}$ \\
\hline 9 & Deep Hole & Liquid $(b)$ & No & Melt \\
\hline 10 & Hydrofracture & Liquid (b) & No & No \\
\hline
\end{tabular}

a. Includes underground manmade structures.

b. All liquid emplacement concepts involve in-place conversion to a solid form.

c. Cooling is provided for an interim period of tens of years until the heat generation rate has decreased to a point that melting will not occur.

d. This deep hole concept is studied for both melting and nonmelting cases.

the fuel reprocessing plant. The solid emplacement concepts involve transportation of the waste, which has been converted to a solid form at the fuel reprocessing plant, crosscountry to a separate disposal site.

4.1.1 Solid Waste Emplaced in Mined Cavity - No Fluid Cooling or Melting

One method of placing waste in appropriate geologic formations is the burial of waste packages (canister filled with solidified waste) in excavations formed by conventional mining techniques. The concept for a
Federal Repository developed by 0ak Ridge National Laboratory (ORNL) is based on the placement of waste canisters in mined voids in bedded salt deposits; Figure 4.31 is similar to the ORNL concept. (116) salt domes and intrusive igneous, argillaecous, and metamorphic formations are other examples of candidates for disposing of solidified high-level radioactive waste into geologic formations by this method.

Waste canisters are buried in the floor of rooms or tunnels excavated in the geologic formation. Floor area required is determined by the 


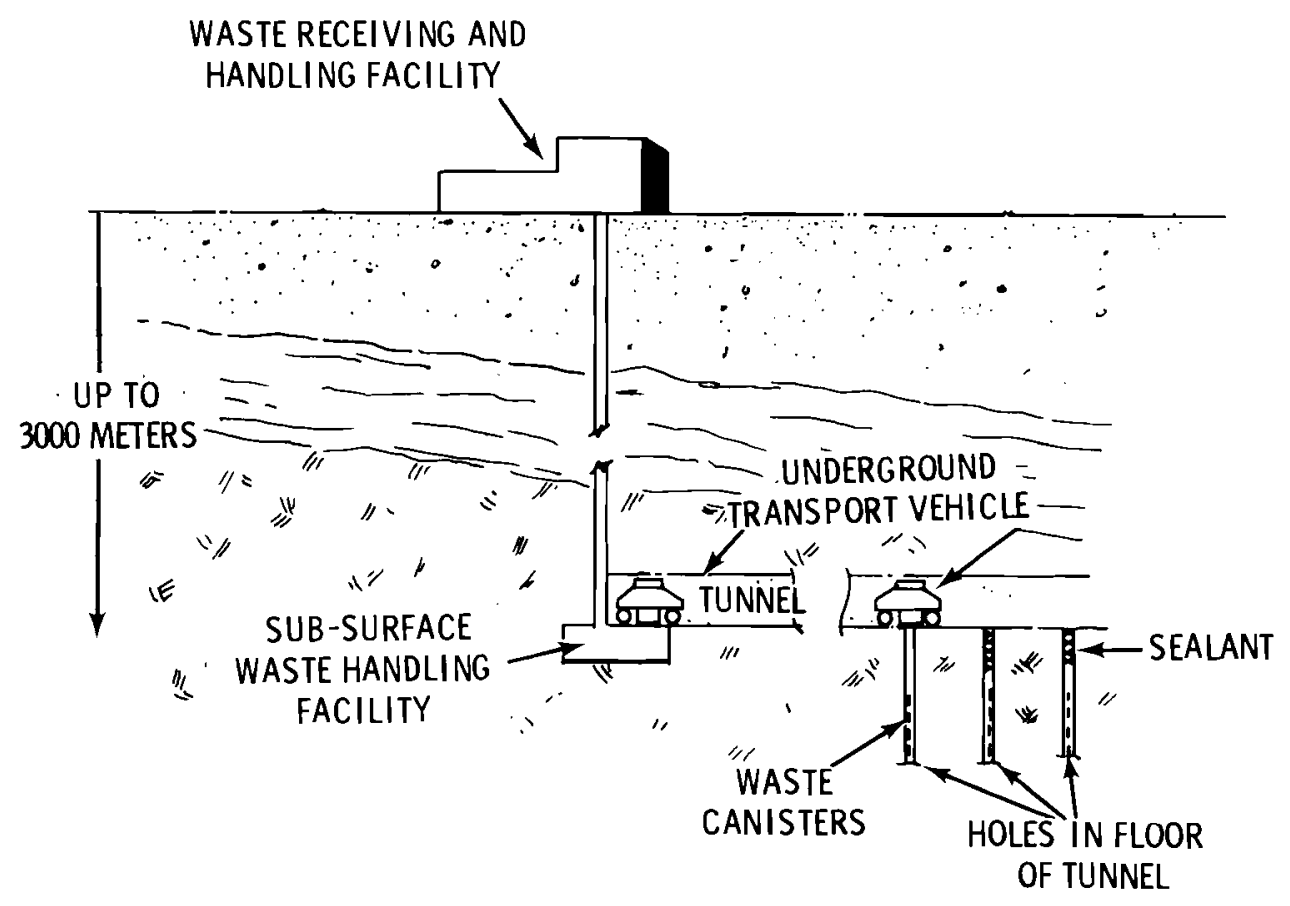

FIGURE 4.31. Solid Waste Emplacement in a Mined Cavity - No Fluid Cooling or Melting

total number of canisters, the number of canisters placed vertically in individual burial holes, the heat generation rate of individual canisters, and the heat dissipation characteristics of the formation. The height and width of rooms and tunnels are determined primarily by the size of subsurface transfer vehicles, overhead requirements needed for the formation of individual burial sites or holes, and rock mechanics. However, typical values would be about 4.5 to 9.0 meters high and 4.5 to 25 meters wide. The need for shoring and linings to prevent tunnel subsidence and convergence would be determined by the rock mechanics of the geologic formation.

The tunnels or rooms would be in a regular array such as shown in Figure 4.32. Prefiltered ventilation air is supplied to the uncontaminated tunnel areas and, by controlling pressures, flows toward the potentially contaminated areas (where waste is contained). Here, the ventilation air is exhausted through a high efficiency filter into a separate ventilation tunnel. The air is then directed to the surface and sent through another bank of high efficiency filters before being routed to a stack that is continuously monitored for radioactivity. The ventilation tunnel and ducts are arranged to assure that air which has passed a potentially contaminated mine area can be isolated from any further contact with personnel.

Other required features such as provisions for mining in one area while disposing of waste in other 

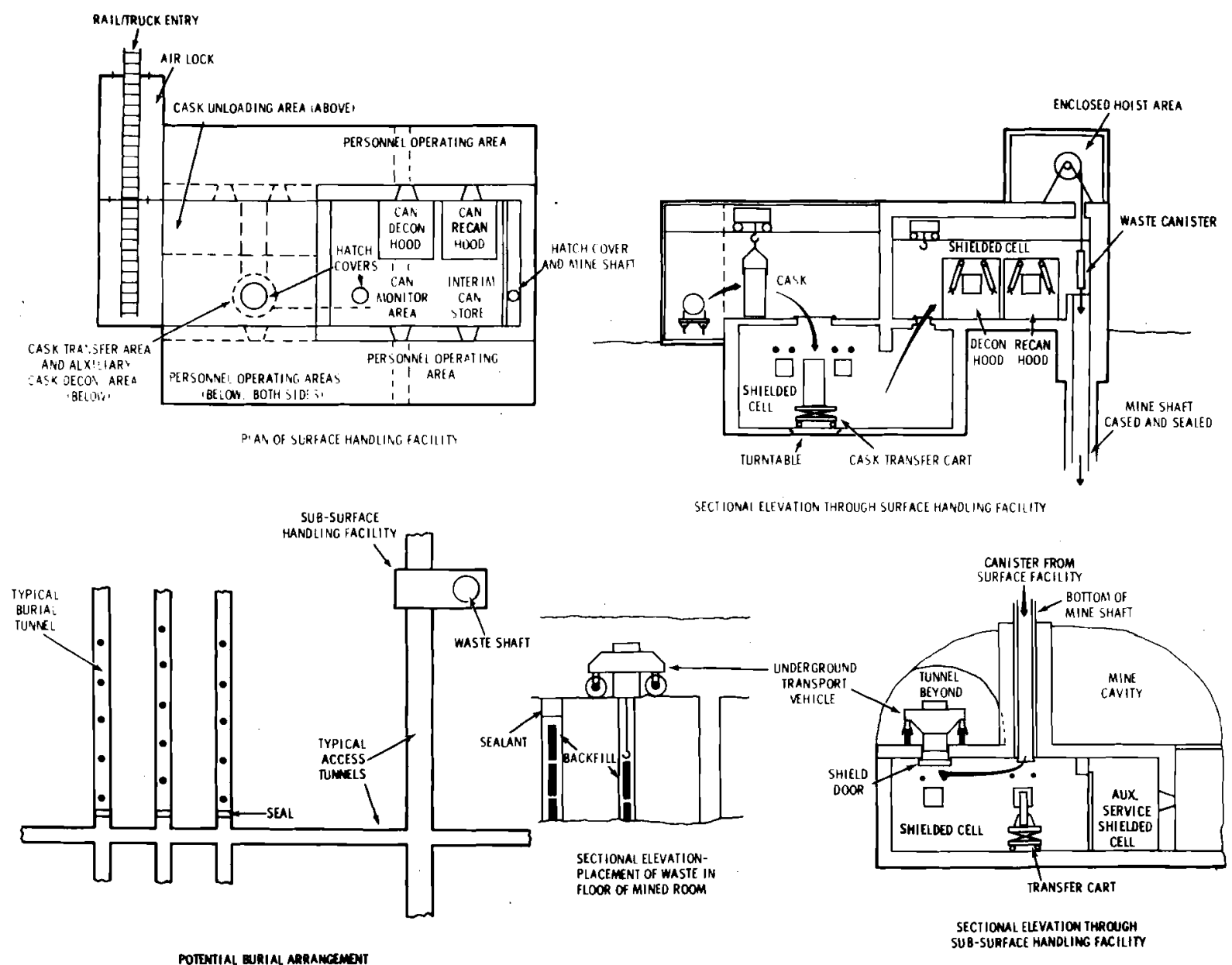

FIGURE 4.32. Overall Facility Needs - Solidified Waste in Mined Cavity

areas, additional shafts and tunnels (e.g., for ventilation, mining, emergency), and auxiliary provisions such as mechanical, electrical, and ventilation equipment, laboratory and office areas, etc., are not shown in Figure 4.32 .

It is estimated that about $90 \mathrm{kilo-}$ meters of burial tunne1, 4.6 meters on a side, would be required to dispose of the 14,700 canisters of highlevel waste produced by the reference reprocessing plant. In addition, nearly 11 kilometers of access tunnel wil1 be required.
Overall characteristics of the concept for placing solid waste directly in a mined cavity with minimum interaction between the waste and the formation are summarized in Table 4.22.

4.1.2 Solid Waste Emplaced in Mined

Cavities - Interim Liquid

Cooling and Conversion to RockWaste Matrix

The major features of this concept for disposing of waste in a mined cavity with waste-rock melting are:

1) the waste is in solid form contained in canisters in a large mined 
IABLE 4.22. Summary of the Overall Characteristics; Solid Waste Emplaced in Mined Cavity - No Fluid Cooling or Melting

Waste Form

Waste Concentration

Operational Features

Candidate Geologic Environment

Retrievability

Monitorability

Extent of Knowledge

Isolation

Possible Pathways to Man's Environment
High integrity solid waste form and canister.

Moderate; inversely proportional to heat content of waste.

Significant canister handing but relatively straightforward; direct "hands-on" control of each canister.

Might include bedded or domed salt, tuff, intrusive igneous, crystalline metamorphic or possibly shale formations.

Relatively good for 50 to 100 years or until operation shutdown; more difficult with time depending on plasticity of formation, corrosion resistance of canister, and maintenance of repository before final sealing.

Limited; direct monitoring of waste impractical, can monitor gross radioactivity release within each major tunnel during operation; can detect radioactivity in nearby water-bearing formations if it should occur; can monitor temperature increase in shallow observation wells.

Fair to good; mining techniques and remote handling techniques established; waste-formation interaction evaluated on shortterm data when considering geologic times; unknown effects of burial of radioactive heat source on geologic formation.

Moderately deep geologic isolation, 300 to 3000 meters or maximum mining depths, depends on geologic formation as the primary containment barrier for geologic times; relatively few manmade penetrations to the surface require sealing.

Natural pathways such as fractures if flowing water present, volcanism, seismic activity, erosion, etc. Pathways attributed to man's actions such as drilling into repository, sabotage, etc. See also Volume 1, Section 3 . cavity; 2) the canisters are cooled by evaporation of surrounding water while the cavity is being filled;

3) the waste canisters are in a close, randomly stacked array; and 4) the waste is ultimately allowed to melt. The time at which the melting phase starts may be varied. Melting might be postponed for up to 100 years by continuing liquid evaporation cooling of the waste. This concept of solid waste placed in a mined cavity is a variation of that proposed by clark. (117)

A pictorial description of the concept is shown in Figure 4.33. Waste canisters are removed from shipping casks in the waste receiving facility, lowered through a drill hole into a lined cavity, and deposited on the cavity floor in a random array. Waste within the cavity is immersed in a boiling water bath, and the resultant steam generated is condensed in a surface facility and returned to the cavity for cooling the waste. operation of the surface cooling system must be continued until the cavity material is permitted to melt and the waste fixed.

In the reference version of this concept, the cavity is doubly lined with high-integrity, corrosion-resistant liners to assure containment of the cooling liquid. The cavity and its tank liner are proposed to be 


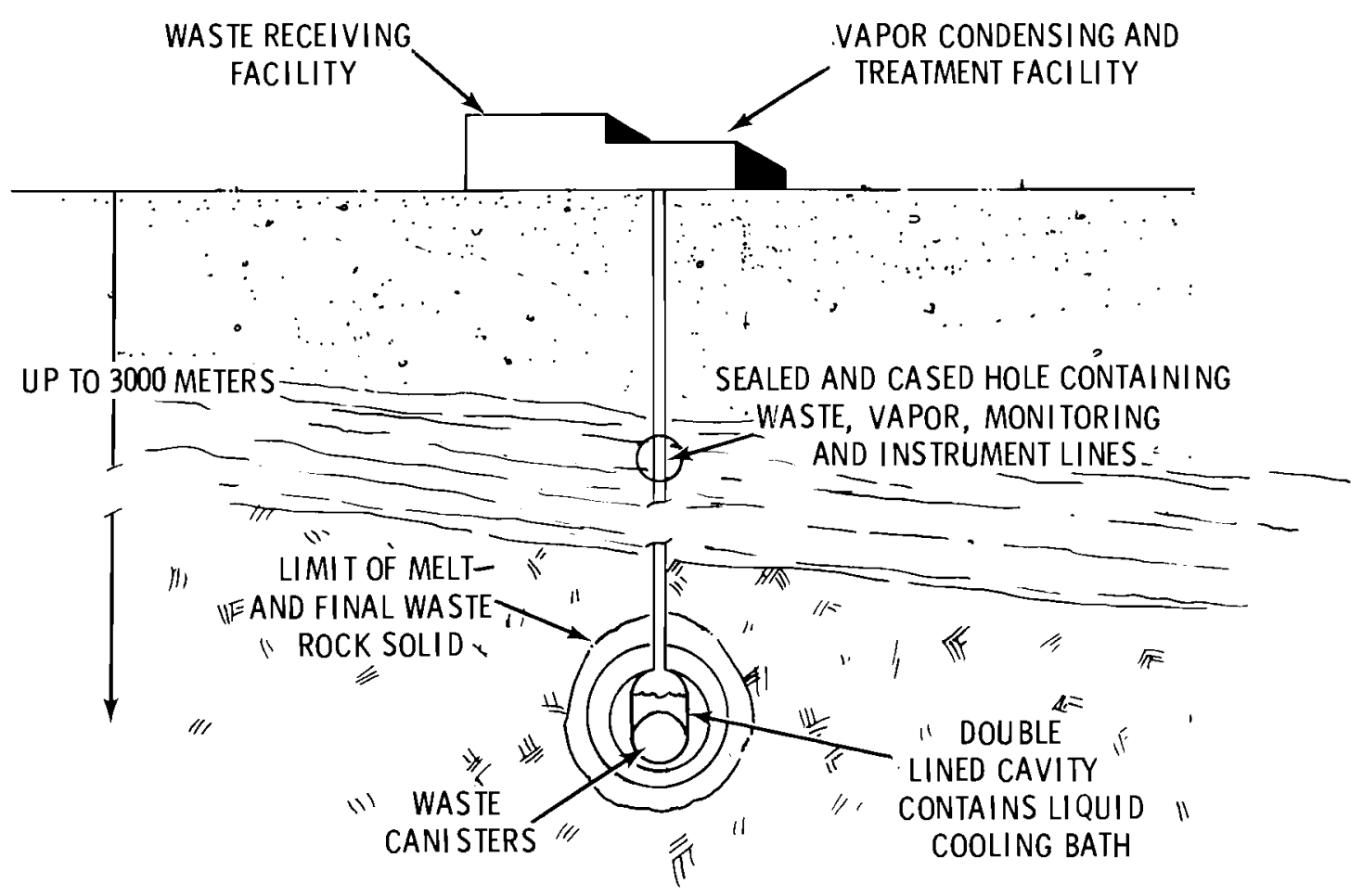

FIGURE 4.33. Solid Waste Emplacement in a Mined Cavity Interim Liquid Cooling and Waste-Rock Melting

either spherical or cylindrical with near spherical ends to provide for maximum structural strength and minimum surface-to-volume ratio. Depending upon specific circumstances, more than one cavity may be used at a site.

In time all the canisters will fail, exposing the solidified waste directly to the boiling water coolant. If cooling is continued, the water within the cavity will gradually leach the radionuclides from the solid waste form. An increase in the radioactivity of the boiling water will result until, in the limit, the solubility of the radionuclides is reached. At the same time, the radioactivity of the condensate and the noncondensable gases will increase. The noncondensable gases will require processing and handling by alternative methods.
The reference case for this concept allows waste-rock melting after shutdown of the liquid cooling phase of cavity operation. Shutdown of the liquid cooling phase of operation will be initiated when 1) the cavity is no longer needed for waste additions or 2) the cavity is full.

An option of this concept is to limit the extent of the melting phase by continuing the condensate recycle step for some time after stopping waste additions. The time required for the condensate recycle to completely eliminate melting of the waste is believed to be in the order of 500 years. To accomplish reliable cooling for this extended period would require very high integrity system components, including the mined cavity, access piping, surface facility, and canisters. 
A flow diagram showing the waste emplacement and the coolant cycle is presented in Figure 4.34. The Figure 4.34 indicates the possibility that other wastes such as low-level waste and fuel cladding waste could be disposed of in the same cavity after suitable pretreatment and encapsulation. In this study, however, only high-level waste is considered.

A conceptual diagram of the canister insertion area and well-head shielded cell room is shown in Figure 4.35. Adjacent pipes of corrosion-resistant material project through the floor into the well-head shielded cell and extend downward to the top of the cavity. The piping includes the main well casing, four intermediate-sized pipes located within it, and several smaller pipes contained inside one of the intermediate pipes.

In the concept shown, the interiors of all of the pipes are made accessible through covers in their tops. Access is for system needs such as inspection, monitoring and repairs and for canister insertion through an intermediate-sized pipe. The steam risers are each routed to more than one of the condensers to provide redundancy for reliability and maintenance. The steam or the condensate may optionally be treated to remove undesirable vaporized and radioactive constituents in the coolant. Recycle water is returned to the cavity through a pipe located within one of the intermediate size pipes. Any noncondensable gases from the condensers will likely be vented to a waste off-gas system for cleanup.

In the concept shown, the annulus between the large outer casing and the intermediate sized pipes will be filled with a monitoring fluid to detect outward leaks from the inner pipes. This fluid can be either a gas or liquid. A similar system

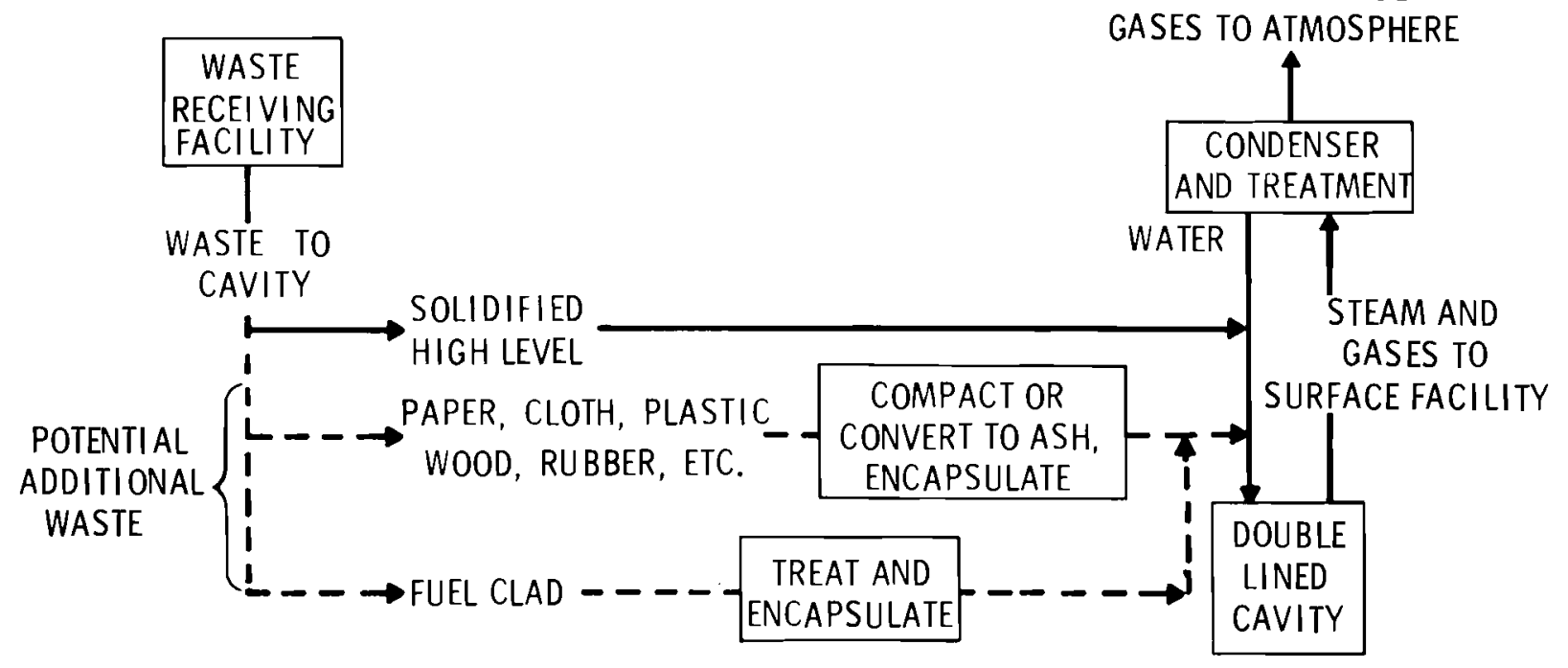

NONCONDENSABLE GASES TO ATMOSPHERE

FIGURE 4.34. Flow Diagram Showing Emplacement of Solid Waste in a Mined Cavity - Interim Liquid Cooling and Waste Rock Melting 
$+$

.

RISER WITH LIQUID PIPING

ANC INSTRUMENTS: INCLUDES

SEVERAL INSTALLED SPARES

MAIN CASING

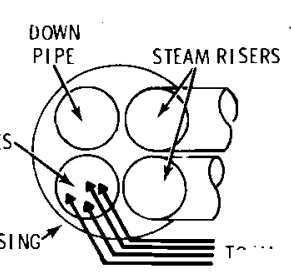

SECTION A-A

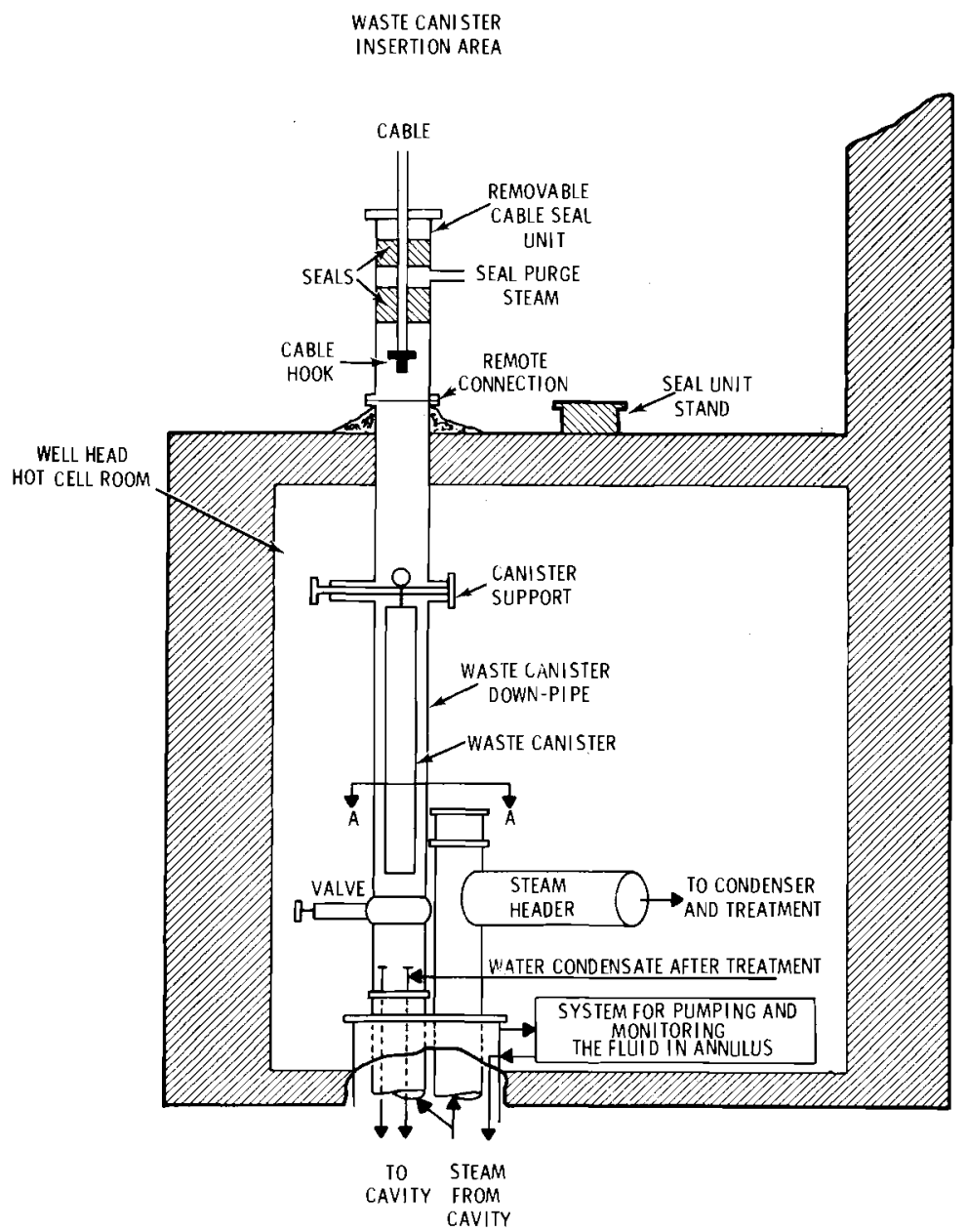

FIgURE 4.35. Wel1-Head Concept for Solid Waste Emplacement in a Mined Cavity - Interim Liquid Cooling and Waste-Rock Melting

using chromated water as the monitoring fluid has been used successfully as a part of a chemical waste disposal system. $(118-120)$ Double encasement is provided for the 1 iquid handling and instrument pipes by being located within an intermediate sized pipe. The inner annulus of these doubly encased pipes could also contain monitoring fluid systems for leak detection.

Casing repairs or modification could be accomplished using downhole 
packers, which are devices used to plug well pipes from the surface. Packer insertion is done routinely in the oil industry in wells with higher surface pressures than required by this concept. (81) special packing elements are available for service up to about $700^{\circ} \mathrm{C}$. Bottom sealing of the intermediate and smaller pipes would be done with well cements or packers.
A cavity volume of about 13,000 cubic meters would be required to receive and serve as a repository for the high-level waste generated by the reference reprocessing plant.

The overall characteristics of the concept for storing solid waste in a mined cavity with interim water cooling followed by waste-rock melting are presented in abbreviated form in Table 4.23 .

TABLE 4.23. Summary of the overall Characteristics, Solid Waste Emplaced in Mined Cavity; Initial Water Cooling; Melting

Waste Form

Waste

Concentration

Operational

Features

Candidate

Geologic

Environment

Retrievability

Monitorability

Extent of Knowledge

Is o lation

Possible Pathways to Man's Environments

0 ther
High integrity solid waste form and canister in a water bath; later allowed to dry and perhaps melt

High in waste form in canisters. High to moderate when waste-rock melts.

Mining of cavity; surface cooling system by steamwater recycle; surface operations for perhaps hundreds of years. In-place drying and perhaps some conversion to melt; eventual self-cooling to solid.

Might include bedded or domed salt, tuff, intrusive igneous, crystalline metamorphic or possibly shale formations.

Difficult as waste in canisters; extremely difficult as rock-waste matrix.

Limited. Can measure temperatures and released radioactivity within cavity, fluid streams, outer casings annuli, and monitor holes; can detect radioactivity in nearby water-bearing formations if it should occur. Direct monitoring of waste is impractical after melting.

Fair. Boiling water stage is somewhat similar to surface liquid storage tank operation. Little is known about random stacking or in-place conversion and $i$ ts heat transfer effects on geologic environment.

Moderately deep geologic isolation, 300 to 3000 meters or maximum mining depths, depends on geologic formation as the primary containment barrier for geologic times; relatively few manmade penetrations to the surface require sealing.

Natural pathways such as fractures if flowing water present, volcanism seismic activity, erosion, etc. Pathways attributed to man's actions such as drilling into repository, sabotage, etc. See also volume 1, Section 3.

Incorporates temporary manmade barrier of tank-type cavity lining. 


\subsubsection{Solid Waste Emplaced in Manmade Structures in Geologic Forma- tions--Interim Air Cooling:}

A major consideration in the disposal of high-level radioactive waste in geologic formations is the removal of heat generated by the waste. Waste temperatures can be kept low by placing the waste in a relatively dispersed array to allow natural heat removal. Or, the waste can be closely spaced in manmade structures within geologic formations with some form of artificial heat removal until the radioactivity decays to a level where natural heat removal methods can be used. The concept discussed here involves the latter situation utilizing air cooling.

Air cooling by natural convection rather than forced convection was chosen for detailed review as the base case because it is a passive system. The reference concept is shown in Figure 4.36. A waste canister is sealed inside a thick-walled metal pod. The pod is then buried in the floor of the tunnel to shield operating personnel from radiation. Radioactive decay heat is conducted along the metal pod wall and is dissipated to the cooling air from a finned surface.

The pod also provides secondary containment and retrievability. An unwelded closure or lid is placed in the pod just above the canister. The space inside the pod above the closure is filled with crushed rock at least to the level of the tunnel floor. The burial trench is also backfilled with crushed rock to provide radiation shielding. The unwelded closure prevents the crushed rock from entering the space between

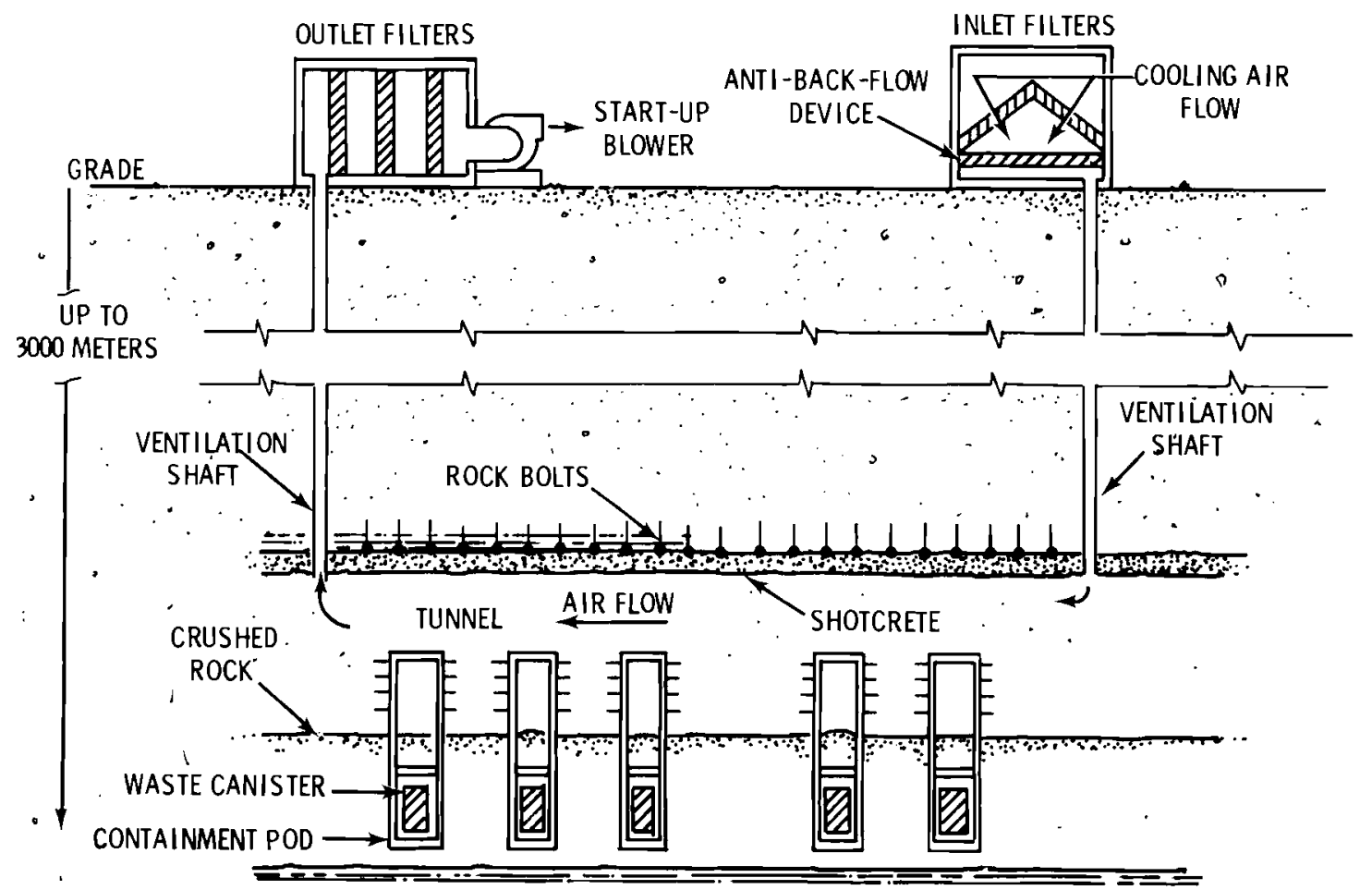

FIGURE 4.36. Solid Waste Emplacement in a Mined Tunnel Interim Natural Convection Air Cooling, No Melting 
the canister and the pod wall so that heat transfer is not impeded. The top of the pod is sealed by a closure weld to provide secondary containment. The welding can be performed using contact methods because of the shielding afforded by the crushed rock.

The tunnel size is determined by the size of the equipment required to place the canister in the pod. Rock bolting and shotcreting may be required for strengthening the tunnel walls and ceilings.

In this concept inlet air from the atmosphere is first filtered to prevent excessive dirt buildup in the waste disposal area. The incoming air flow is then divided to ventilate the personnel access area and to air cool the waste canisters. Upon leaving the waste disposal area, the air rises up the outlet shaft through a high-efficiency filter system where it is cleaned before being released to the atmosphere. A blower is used to initiate the draft but is not needed once the draft is established.

Waste canisters are spaced to permit heat removal by the geologic formation so as to maintain waste and rock temperature below melting after termination of the natural draft cooling in about 100 years. After access areas are sealed, waste heat is conducted to the rock. Canister spacing determined in this manner requires a large disposal area. Alternatively, the canister spacing could be relatively small at the time of placement and then, with additional tunneling, increased when use of the cooling system is terminated.

About 5.5 kilometers of burial tunnel, 9 meters in diameter, would be required to dispose of the highlevel waste produced by the reference reprocessing plant.

other air-cooling methods reviewed and compared with natural convection cooling include single-pass forced convection, recirculation and evaporative air cooling.

Single-pass forced convection air cooling requires the same equipment as natural convection cooling. However, the blower must be operated continuously and, because of the higher available pressure, the shaft or stack diameter can be made smaller than in the case of natural convection. The optimum shaft diameter for single-pass forced convection cooling would be determined by balancing drilling or mining costs against blower costs. Several parallel blowers and emergency power supplies may be needed to provide high reliability. In the case of a power failure, the rise in air temperature would induce a natural draft which would keep the waste at a tolerable temperature for the relatively short time required to restore the blower operation.

A forced convection concept utilizing finned-tube coolers for cooling recirculated air would require more complex equipment. (121) A fan recirculates air past a finned-tube heat exchanger which removes the decay heat and discharges it either directly to the atmosphere or indirectly through circulating cooling water. In this latter case, the water is cooled in an evaporative or wet cooling tower. The water coolant would be isolated from the waste to assist in preventing an accidental release of radioactivity. 
Another approach to heat removal is air cooling by evaporative cooling of the air. Here the equipment requirements would be similar to the preceding system except that the water coolant system including the finned-tube heat exchanger and cooling tower would be absent. Instead, the recirculating air would pass through an underground evaporative cooler. The major advantage of this system would be the reduction in net cooling air flow compared with single- pass air cooling. Another variation of this concept would be single-pass air cooling using evaporative cooling of the air. Such evaporative cooling methods may be attractive for storage sites in hot, arid regions.

Overall characteristics of the mined cavity concept with heat dissipation to the geologic formation and minimum interaction between the waste and the formation with fluid cooling are summarized in Table 4.24.

TABLE 4.24. Summary of the Overall Characteristics; Solid Waste Emplaced in Manmade Structure in Mined Cavity; Initial Air Cooling; No Melting:

\author{
Waste Form \\ Waste Concentration \\ Operational Features \\ Candidate Geologic \\ Environment \\ Retrievability
}

Monitorability

Extent of Knowledge

Isolation

Possible Pathways to Man's Environment
High integrity solid waste form and canister.

Moderate; inversely proportional to heat content of waste.

Significant canister handling but relatively straightforward; direct "hands-on" control of each canister.

Might include bedded or domed salt, tuff, intrusive igneous crystalline metamorphic or possibly shale formations.

Relatively good for 50 to 100 years or until operation shutdown; more difficult with time depending on plasticity of formation, corrosion resistance of canister, and maintenance of repository before final sealing.

Limited; direct monitoring of waste impractical; can monitor gross radioactivity release within each major tunnel during operation; can detect radioactivity in nearby water-bearing formations if it should occur.

Fair to good; mining techniques and remote handling techniques established, waste-formation interaction evaluated on short-term data when considering geologic times; unknown effects of burial of radioactive heat source on geologic formation.

Moderately deep geologic isolation, 300 to 3,000 meters or maximum mining depths, depends on geologic formation as the primary containment barrier for geologic times, although several manmade penetrations to the surface require sealing.

Natural pathways such as fractures if flowing water present, volcanism, seismic activity, erosion, etc. Pathways attributed to man's actions such as drilling into repository, sabotage, etc. See also volume 1, Section 3 . 
4.1.4 Solid Waste Emplaced in Manmade Structures in Geologic Formations--Interim Water Cooling

Use of water cooling to remove the heat generated by radioactive decay is an alternative to the air cooling concept described in the previous section. For this concept, heat removal by radiant heat transfer to boiling water was selected as the base case. A schematic cross section diagram of a system is shown in Figure 4.37. The underground facility is a manmade structure designed to witnstand earthquakes and shifting of the rock formation. The waste is placed in the shielded lower part of a cylindrically shaped storage area. Water coolant is placed in a sealed pressure vessel which surrounds the water canisters. Steam generated by the waste is piped to the heat exchange system at the earth's surface where it is condensed and returned to the waste storage area. A side stream of the coolant is treated to remove radioactivity.

NONCONDENSABLES TO ATMOSPHERE

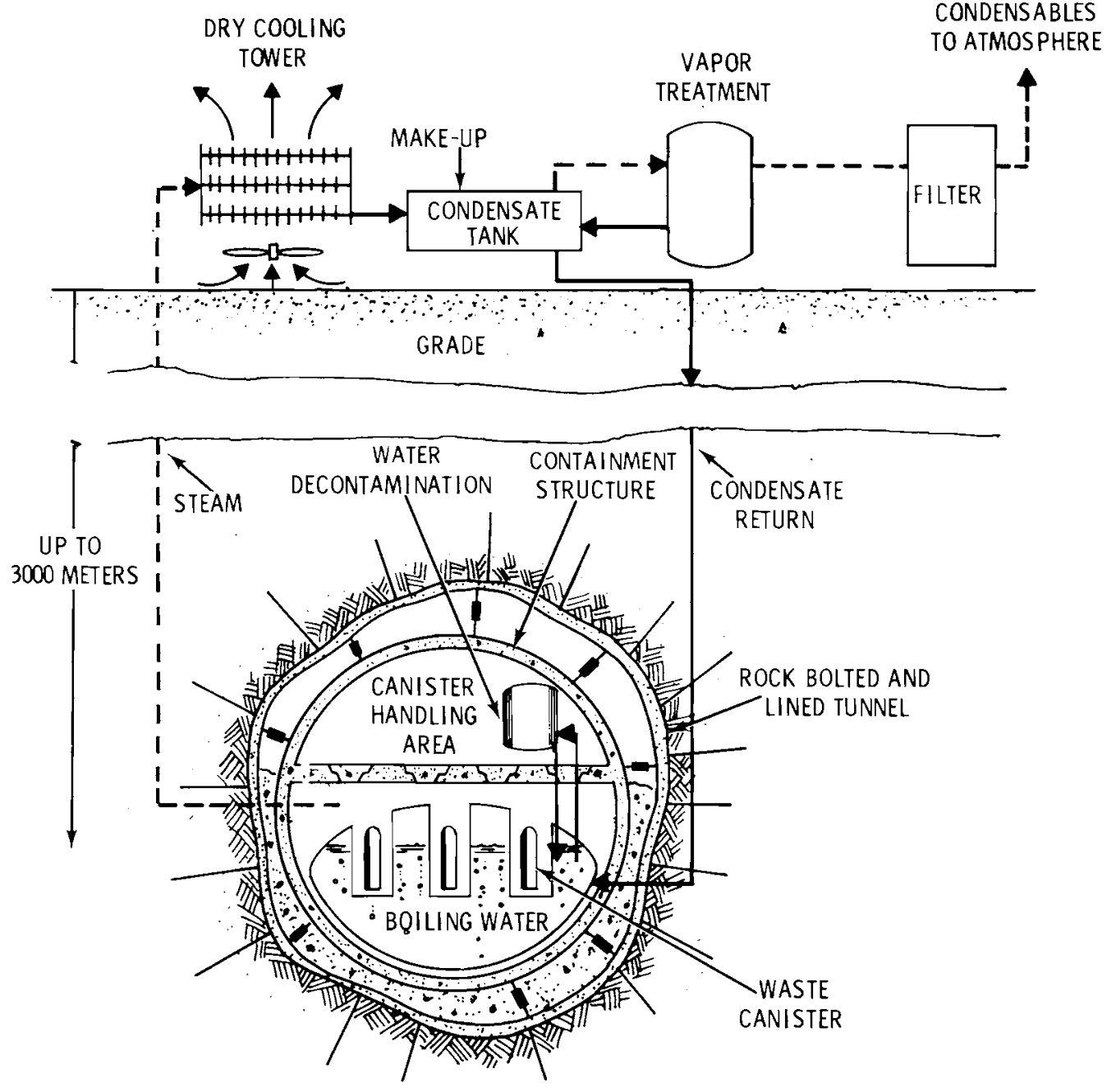

FIGURE 4.37. Solid Waste Emplacement in Manmade Structure with Interim Boiling Water Cooling, No Melting 
The stream could be treated at the surface or underground as shown.

Heat is transferred from the waste canister to the walls of its surrounding "thimble" within the waterfilled vessel by radiation and free convection and then to the water by boiling heat transfer. The heat is carried to the surface as steam, condensed in a dry cooling tower and returned. If the steam is generated at a pressure of two atmospheres, a pressure tank of elliptical cross sectional dimensions of 7.6 and 15 meters would require a wall thickness of about 1 centimeter of low-alloy steel. Alternatively, the concept could use a boiling water vessel at near ambient pressure and depend on vapor pumps to transfer the vapors to the heat removal system at the surface.

Assuming a heat load of 2.5 megawatts for each cooling unit (2.5 megawatts is about five percent of the total heat removal requirements in the year 2000 if 5 -year old waste is shipped to the disposal site), the pipe diameter required for steam flow to the surface without pumping would be about 50 centimeters if the steam pressure in the disposal cavity is 2 atmospheres. The condensate may be returned in the same line without an appreciable increase in flow resistance.

Overall characteristics of the mined concept with heat dissipation to the geologic formation and minimum interaction between the waste and the formation with fluid cooling are summarized in Table 4.25 .
4.1.5 Liquid Waste Emplaced in a Mined Cavity - In-Place Drying and Conversion to Rock-Waste Matrix

In this concept the high-level liquid waste is managed by a system whose main feature is a mined cavity located below the surface and isolated from mobile groundwater (Figure 4.38). The liquid waste is placed initially into the cavity and stored for an interim period of time. During this time heat is removed from the self-boiling waste by routing the vapors to a surface facility for condensing, treatment, and recycle to the cavity. Essential to this concept is the location of the fuel reprocessing plant at the waste disposal site.: The management of the waste by this concept is divided into three distinct time steps:

1. Interim storage as a boiling 1 iquid for the 1 ife of the reprocessing plant and perhaps somewhat longer;

2. In-place conversion and melting; and

3. Solidification to a monolithic solid resulting in ultimate disposal away from man's environment for geologic time periods.

The principal steps in the disposal process are shown with a time scale in Figure 4.39. The process operation during the liquid storage phase, Step 1 above, is shown diagrammatically in Figure 4.40. The waste is allowed to boil and the condensate is recycled. Also indicated in Figure 4.40 is the possibility that other types of waste from the fuel reprocessing plant might be 
IABLE 4.25. Summary of the Overall Characteristics; Solid Waste

Emplaced in Manmade Structure in Mined Cavity;

Initial Water Cooling; No Melting:

Waste Form

Waste Concentration

operational features

Candidate Geologic Environment

Retrievability

Monitorability

Extent of knowledge

Isolation

Possible Pathways to Man's Environment
High integrity solid waste form and canister.

Medium; inversely proportional to heat content of waste.

Significant canister handling but relatively straightforward; direct "hands-on" control of each canister. Fluid cooling allows more flexible and positive control of temperature of waste and rock.

Might include bedded or domed salt, tuff, intrusive igneous, crystalline metamorphic or possibly shale formations.

Relatively good for 50 to 100 years or until operation shutdown; more difficult with time depending on plasticity of canister, and maintenance of repository before sealing.

Limited; direct monitoring of waste impractical; can monitor gross radioactivity release within each major tunnel during operation; can detect radioactivity in nearest water-bearing formations if it should occur.

Fair to good; mining techniques and remote handling techniques established; waste-formation interaction evaluated on shortterm data when considering geologic times; unknown effects of burial of radioactive heat source on geologic formation.

Moderately deep geologic isolation 300 to 3,000 meters or maximum mining depths; depends on geologic formation as the primary containment barrier for geologic times, although several manmade penetrations to the surface require sealing.

Natural pathways such as fractures if flowing water present, volcanism, seismic activity, erosion, etc. Pathways attributed to man's actions such as drilling into repository, sabotage, etc. See also volume 1 , Section 3 .

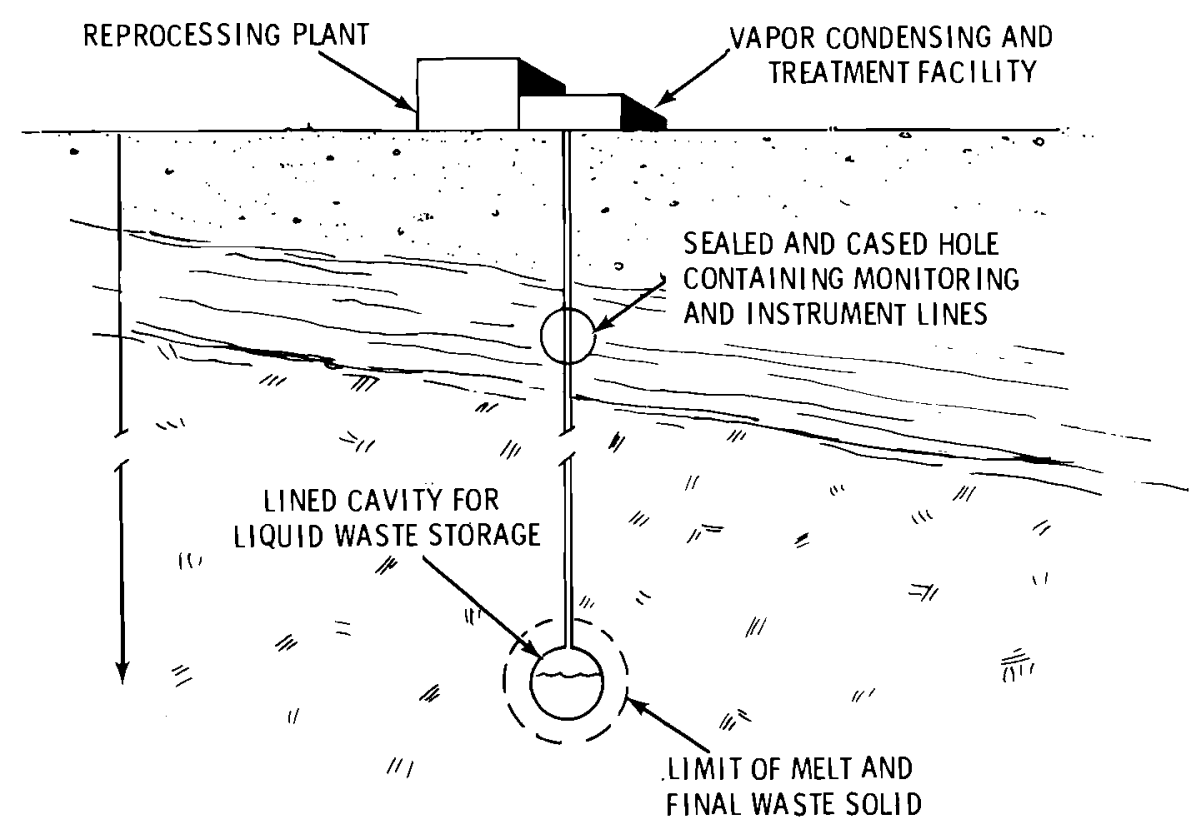

FIGURE 4.38. Liquid Waste Emplacement in a Mined Cavity In-Place Drying and Conversion to Rock-Waste Matrix 

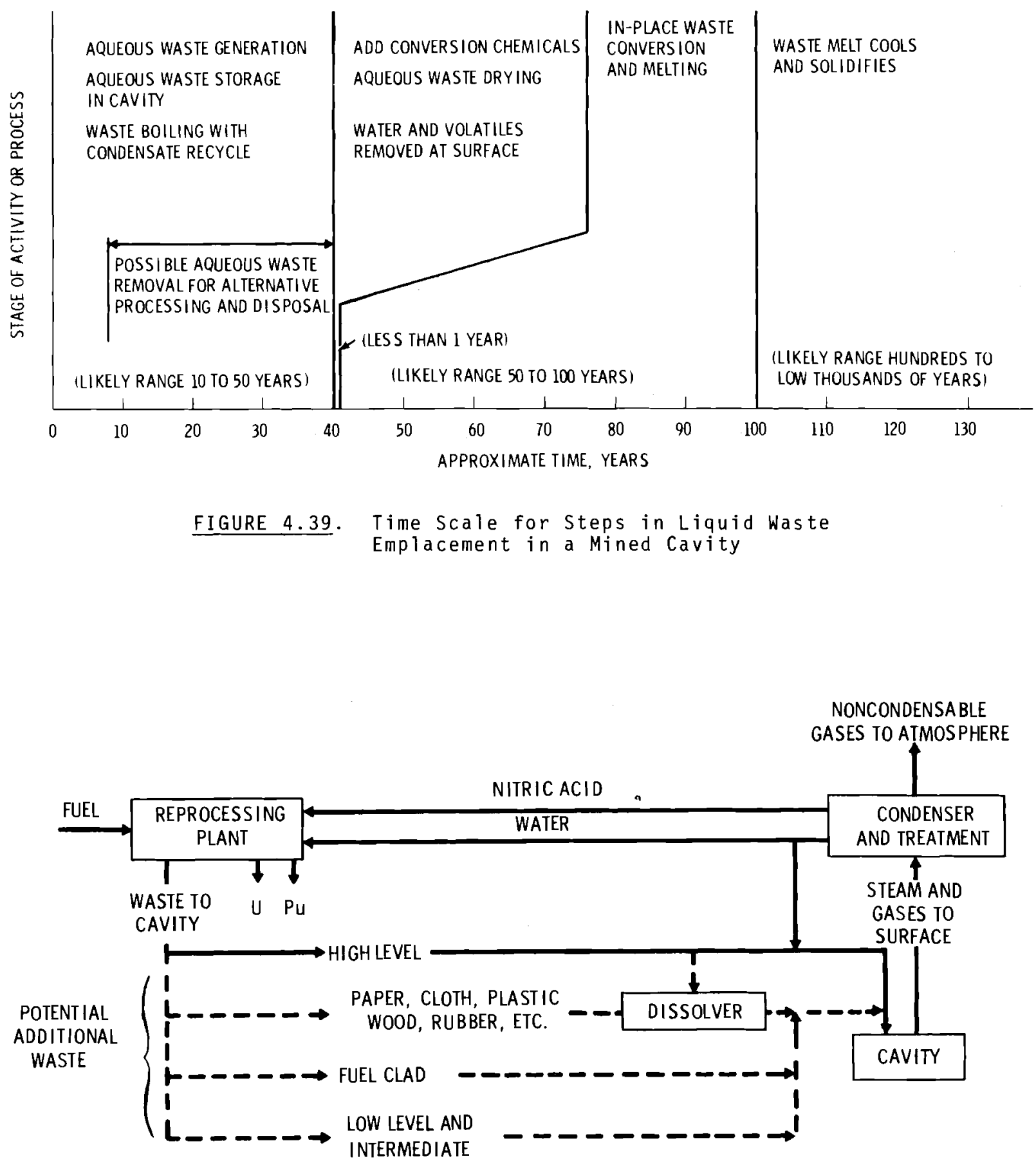

FIGURE 4.40. Flow Diagram for Liquid Waste Emplaced

in Mined Cavities - In-Place Drying

and Conversion to Rock-Waste Matrix 
disposed of with this concept: high, intermediate, and low-level liquid waste; fuel clad; and other contaminated solid or liquid materials. In this study, however, only high-level 1 iquid waste is considered.

The cavity can be mined and the shaft drilled using conventiondl techniques. The cavity is lined with a high-integrity and corrosion-resistant liner to assure containment during the liquid operating state (the concept may succeed without a lining). The cavity and its tank liner are proposed to be either spherical or cylindrical with nearly spherical ends to provide for maximum structural strength and minimum surface-to-vol- ume ratio. Depending upon specific circumstances, more than one cavity may be used at a site. About 4,000 cubic meters are required for the cavity volume to dispose of the high-level 1 iquid waste generated by the reference reprocessing plant. In operating with liquid waste, the cavity provides the same function as a near-surface 1 iquid storage tank.

A conceptual diagram of what might be contained within the well-head shielded cell is shown in Figure 4.41 . Pipes of corrosion-resistant material project through the floor into the wel1-head shielded cell and extend downward to the top of the cavity. The piping includes the

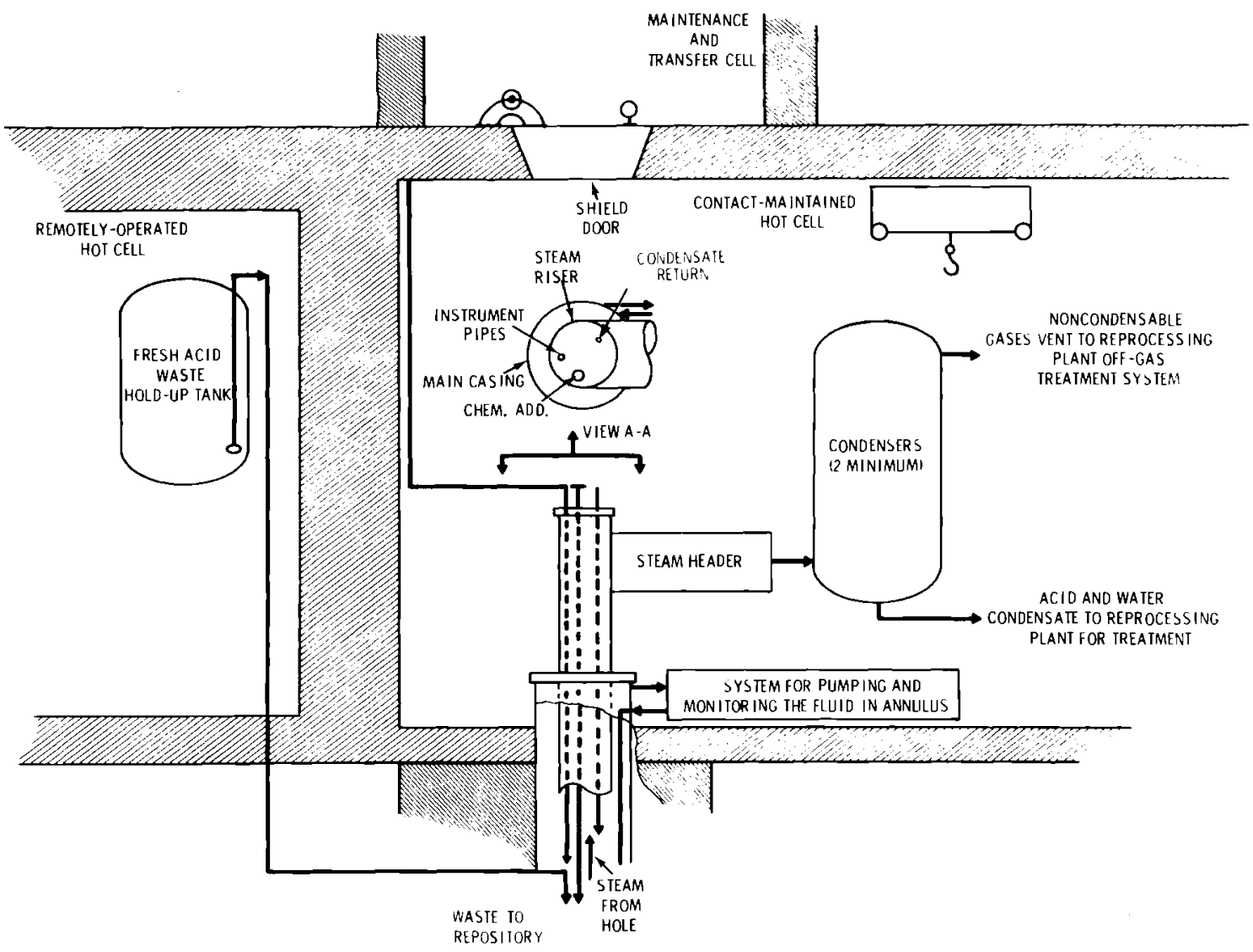

FIGURE 4.41. Facility Requirements at the Well Head Liquid Waste Emplaced in Mined Cavities 
large-diameter main we 11 casing, a steam pipe concentric within the casing, and several smaller pipes contained inside the steam pipe.

In the concept, the interiors of al1 of the pipes are made accessible through covers in their tops. Access is for system needs such as inspection, monitoring, and repairs. The steam risers are each routed to more than one of the condensers to provide redundancy for reliability and maintenance. The steam or the condensate is treated to remove undesirable, vaporized, and radioactive constituents from the coolant. The condensate may require chemical processing prior to returning it to the cavity. Recycle condensate is returned to the cavity through a pipe located within one of the intermediate size pipes. Liquid high-level waste is added to the cavity through a separate smal1 pipe which is shielded from the well head and the steam-condensate system. Any noncondensable gases from the condensers will likely be vented to a waste off-gas system for cleanup.

In the concept shown, the annulus between the large outer casing and the intermediate-sized pipes will be filled with a monitoring fluid to detect outward leaks from the inner pipes. This fluid can be either a gas or liquid. A similar system using chromated water as the monitoring fluid has been used successfully as part of a chemical waste disposal system. $(118-120)$ Double encasement is provided for the 1 iquid handling and instrument pipes by being located within an intermediatesized pipe. The inner annulus of these doubly-encased pipes could also contain monitoring fluid systems for leak detection.

Casing repairs or modification can be accomplished using downhole packers as discussed in Concept 2 .

overal1 characteristics of the concept for placing liquid waste in mined cavities with in-place drying and conversion to a rock-waste matrix are summarized in Table 4.26.

4.1.6 Liquid Waste Emplaced in Exploded Cavities - In-Place Drying and Conversion to Rock-Waste Matrix

High-level liquid waste is emplaced in an exploded underground cavity isolated from mobile groundwater, (68) see Figure 4.42. The cavity is formed at depths greater than 3000 meters. The process is similar to that for a mined cavity (Concept 5), except for the form of the cavity. Because in most materials the ceiling of an explosionproduced cavity collapses, the cavity will be rubble-filled rather than open. Unless otherwise stated, the characteristics are similar to those of concept 5 .

The explosive method of cavity formation produces differences in the utility and technical feasibility, but the concept description is not significantly altered from that of the mined cavity. These differences are:

1. The exploded cavity can be formed at greater depths than can the mined.

2. Piping installation into the exploded cavity is more difficult. 


\begin{tabular}{|c|c|}
\hline TABLE & $\begin{array}{l}\text { Summary of the Overall Characteristics; } \\
\text { Liquid Waste Emplaced in Mined Cavity; } \\
\text { Initial Reflux Cooling; Melting: }\end{array}$ \\
\hline Waste Form & $\begin{array}{l}\text { Liquid during emplacement; rock-waste matrix after in- } \\
\text { place melting and solidification. }\end{array}$ \\
\hline Waste Concentration & High as liquid; low to moderate as final solid. \\
\hline Operational Features & $\begin{array}{l}\text { Surface operations only. Surface vapor condensing and } \\
\text { recycle system. In-place, self-conversion to melt; even- } \\
\text { tual self-cooling to solid. }\end{array}$ \\
\hline $\begin{array}{l}\text { Candidate Geologic } \\
\text { Environment }\end{array}$ & $\begin{array}{l}\text { Might include bedded or domed salt, tuff, intrusive igneous, } \\
\text { crystalline metamorphic or possibly shale formations. }\end{array}$ \\
\hline Retrievability & $\begin{array}{l}\text { Some difficulty as liquid; very difficult to nonretrievable } \\
\text { as a matrix. }\end{array}$ \\
\hline Monitorability & $\begin{array}{l}\text { Can monitor temferatures in and adjacent to cavity and in } \\
\text { access holes during aqueous storage; can monitor radio- } \\
\text { activity in access annuli and test holes; cannot monitor } \\
\text { precisely some events occurring meltdown and cooling stages; } \\
\text { can detect radioactivity in nearby water-bearing formations } \\
\text { if it should occur; can monitor surface support. }\end{array}$ \\
\hline Extent of knowledge & $\begin{array}{l}\text { Aqueous stage operation is similar to surface liquid storage } \\
\text { tank operation. Meltdown and cooling knowledge is largely } \\
\text { inferred. }\end{array}$ \\
\hline Isolation & $\begin{array}{l}\text { Moderately deep geologic isolation, } 300 \text { to } 3,000 \text { meters; } \\
\text { depends upon mobility of molten sphere of rock-waste; de- } \\
\text { pends partly upon effective manmade sealing of modest } \\
\text { number of manmade penetrations. }\end{array}$ \\
\hline $\begin{array}{l}\text { Possible Pathways to } \\
\text { Man's Environment }\end{array}$ & $\begin{array}{l}\text { Natural pathways such as fractures if flowing water present, } \\
\text { volcanism, seismic activity, erosion, etc. Pathways attrib- } \\
\text { uted to man's actions such as drilling into repository, } \\
\text { sabotage, etc. See also volume l, Section } 3 \text {. }\end{array}$ \\
\hline other & $\begin{array}{l}\text { Ability to control melt stage must be predicted tefore } \\
\text { starting melt. }\end{array}$ \\
\hline
\end{tabular}

3. The exploded cavity cannot be lined or well inspected, and contains cracks in the walls.

4. The chance of hot-spot formation, unwanted local decomposition and offgasing, local melting, and sudden cooling by water contact are all greater in the exploded cavity than in the mined cavity.

Cavity forming using Plowshare techniques is well established. Cavity formation using chemical explosive volumes can be achieved utilizing stepped charges. Depending upon specific circumstances, more than one cavity might be required at a single site.

Typical shielded cell facility requirements are basically the same as those for Concept 5 shown in Figure 4.41 .

An arrangement for the piping downhole into the cavity is presented in Figure 4.43. The cavity is penetrated by each of the main casings. The steam up-flow pipes are located within and concentric to the main casing. Condensate return 1 ines and mon- 

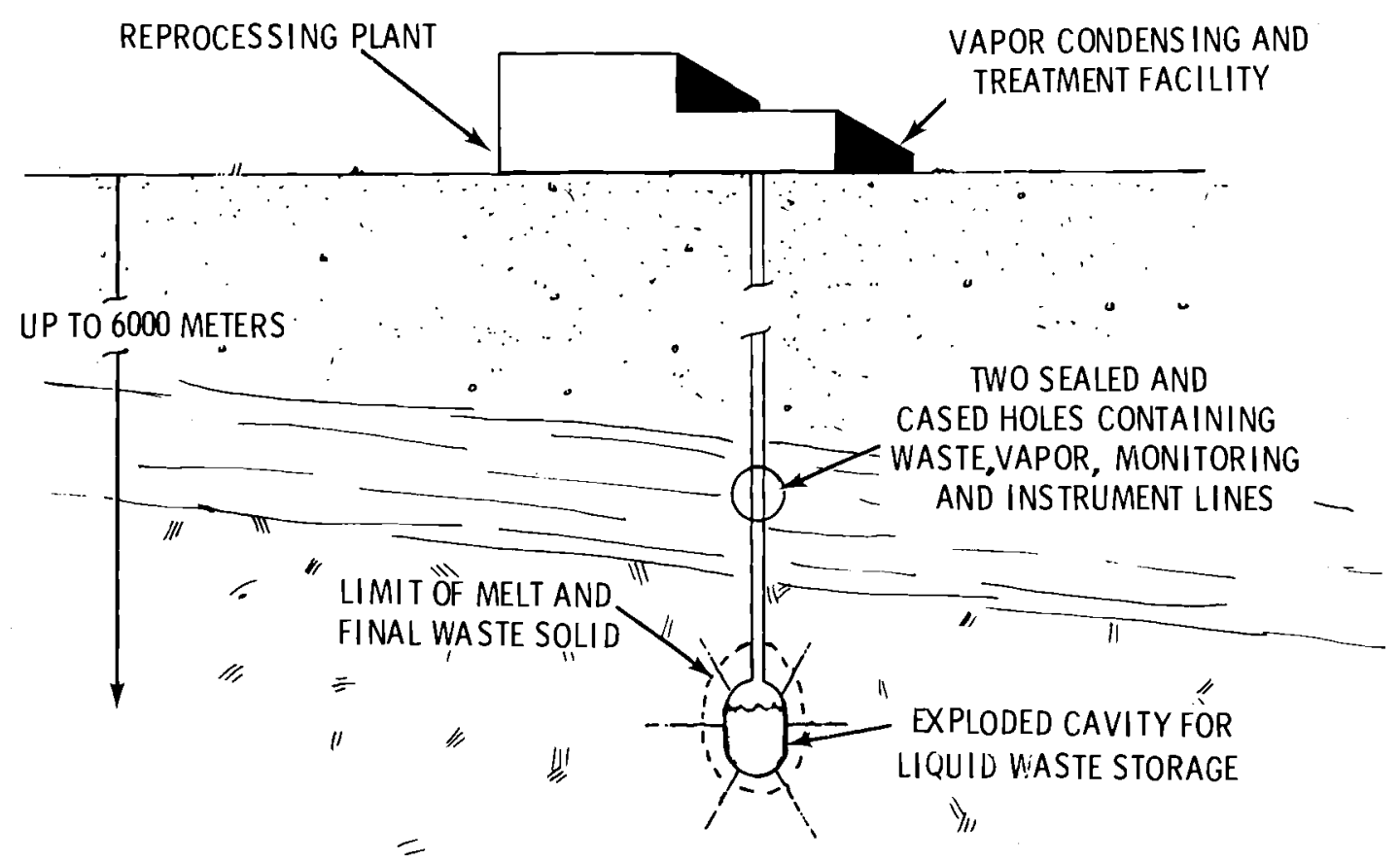

FIGURE 4.42. Liquid Waste Emplacement in an Exploded Cavity - In-Place Drying and Conversion to Rock-Waste Matrix

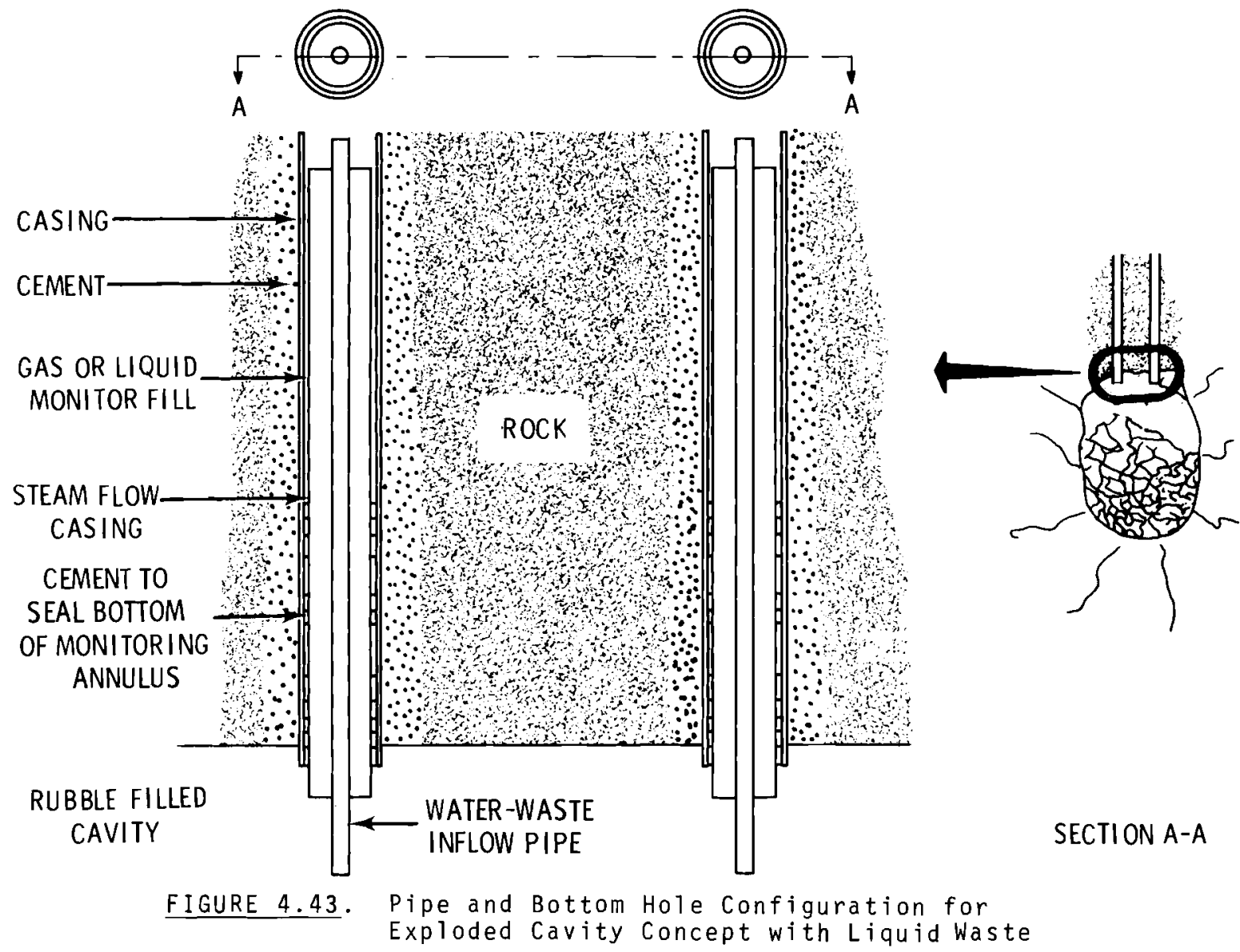


itoring instrumentation leads will be contained inside the steam pipe.

Overall characteristics of the concept for placing liquid waste in exploded cavities with in-place drying and conversion to a rock-waste matrix are summarized in Table 4.27.

\subsubsection{Solid Waste Emplaced in a Matrix of Drilled Holes - No Melting}

The method of placing wastes in appropriate geologic formations, shown in Figure 4.44 , is based on lowering waste packages (canisters filled with solidified waste) into an array of holes that have been drilled into the formation from the earth's surface. (122) This concept was originally proposed as a method for placing waste canisters in bedded salt deposits and as an alternative to the mined cavity concept for a Federal Repository. (123) The primary feature of the drilled hole concept is that all operations are conducted from the surface. Salt domes, argillaceous, intrusive igneous, and metamorphic

TABLE 4.27. Summary of the Overall Characteristics; Liquid Waste Emplaced in Exploded Cavity; Initial Reflux Cooling; Melting:

Waste Form

Waste Concentration

operational Features

Candidate Geologic Environment

Retrievability

Monitorability

Extent of knowledge

Isolation

Possible Pathways to Man's Environment

other
Aqueous waste during emplacement; rock-waste matrix after inplace melting and solidification.

High as liquid; low to moderate as final solid.

Surface operations only. Surface vapor condensing and recycle system. In-place, self-conversion to melt; eventual selfcooling to solid. Nuclear explosion produced cavity.

Might include intrusive igneous, crystalline metamorphic, possibly shale or salt (bedded or domed) formations.

very difficult to nonretrievabie.

Limited; can monitor temperatures in cavity and in access holes during aqueous storage; can monitor radioactivity in access annuli and test holes; cannot monitor precisely some events occurring in meltdown and cooling stages; can measure radioactivity in nearest water-bearing formations; can monitor surface support.

Aqueous stage is inferred from nuclear cavity work and to surface liquid storage-tank operation. Meltdown and cooling knowledge is largely inferred. Uncertainty about effect of wall cracking.

Deep geologic isolation, down to about 6,000 meters; depends upon mobility of molten sphere of rock-waste; depends upon extent and degree of cracking of geologic formation; depends partly upon effective manmade sealing of modest number of manmade penetrations.

Natural pathways such as fractures if flowing water present, volcanism, seismic activity, erosion, etc. Pathways attriuted to man's actions such as drilling into repository, sabotage, etc. See also Volume 1, Section 3.

Ability to control melt stage must be predicted before starting melt. 


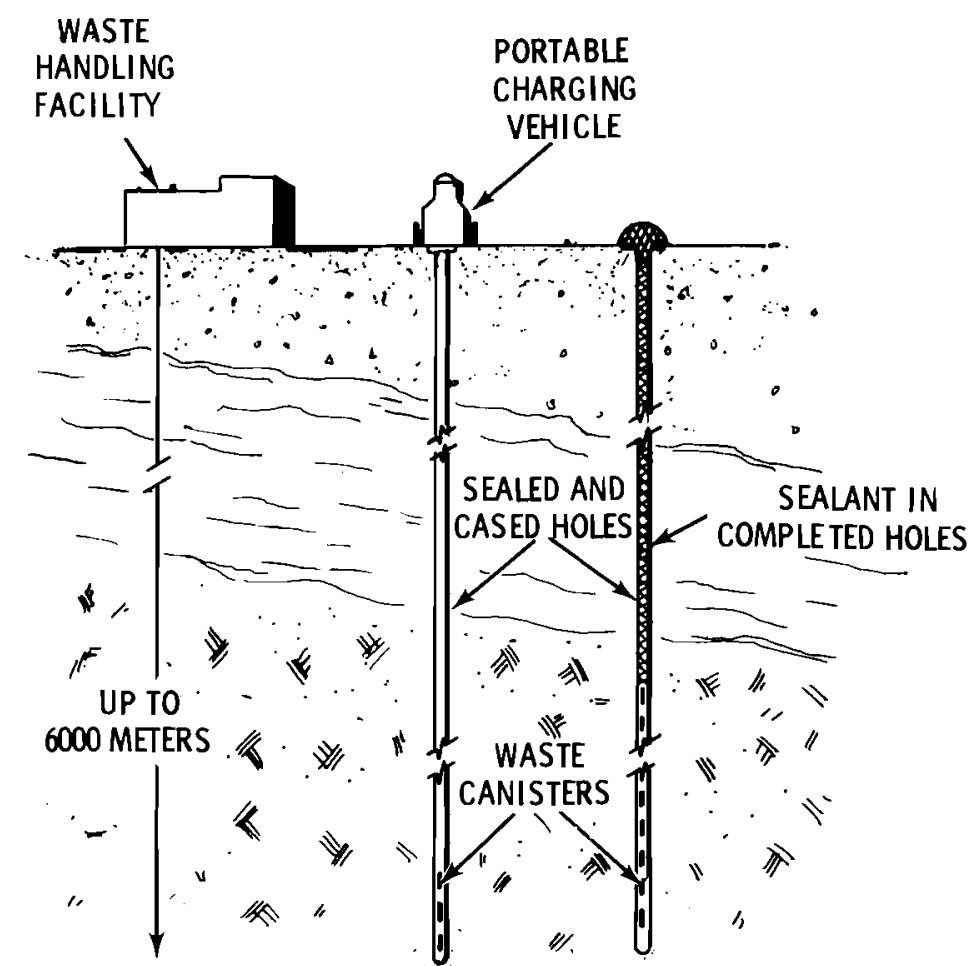

FIgURE 4.44. Solid Waste Emplacement in a Matrix of Drilled Holes - No Melting

formations are other examples of geologic candidates for the drilled hole concept. The concept is currently envisioned as being appropriate for depths ranging from about 300 to 6000 meters.

The number of holes required will depend primarily on the number of canisters and the thickness of the geological strata or formation. Assuming a 10 year hold-up time at the reprocessing plant, about 3000 waste canisters, each having a diameter of 0.3 meters and a length of 3 meters, would be available annually by the year 2000. (124) This quantity corresponds to a vertical space utilization rate within a single hole of about 25 meters per day; relatively thin geologic formations could require an immense number of drilled holes. Spacing of the drilled holes will depend on the heat generation rate of individual canisters and the heat dissipation characteristics of the geologic formation. Waterbearing formations must be sealed off by setting and cementing a casing. To provide a hole which can be freed of all water before waste is emplaced, it is probable that the casing will be required all the way to the bottom of the hole.

As shown in Figure 4.45 , surface facilities consist of a handing facility (cask unloading area and shielded cells), drill rig, and charging vehicle. The latter is a selfpowered vehicle for lowering the canisters into the drilled holes. The vehicle will probably travel on rails and will be equipped with run and jog 


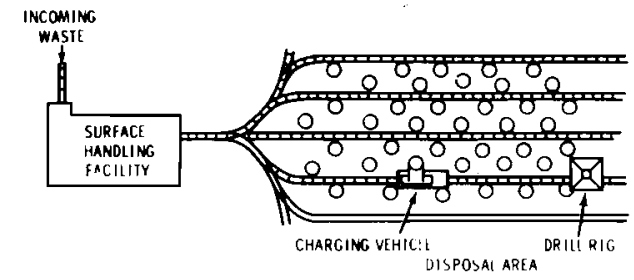

OVERALL ARRAR,GEALE NI OH FACTLITY

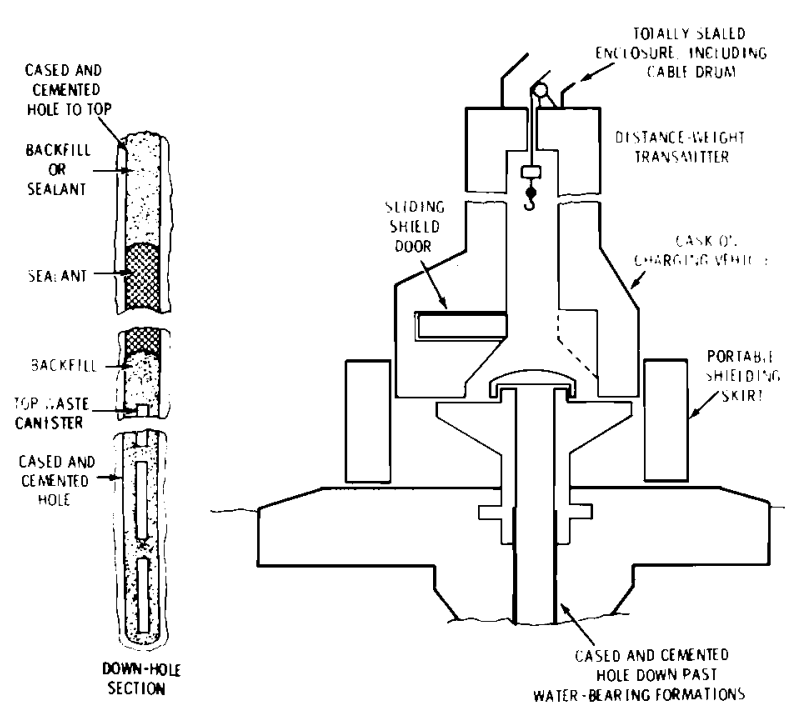

SECIION THROUGH TOP OF EACH HOLE
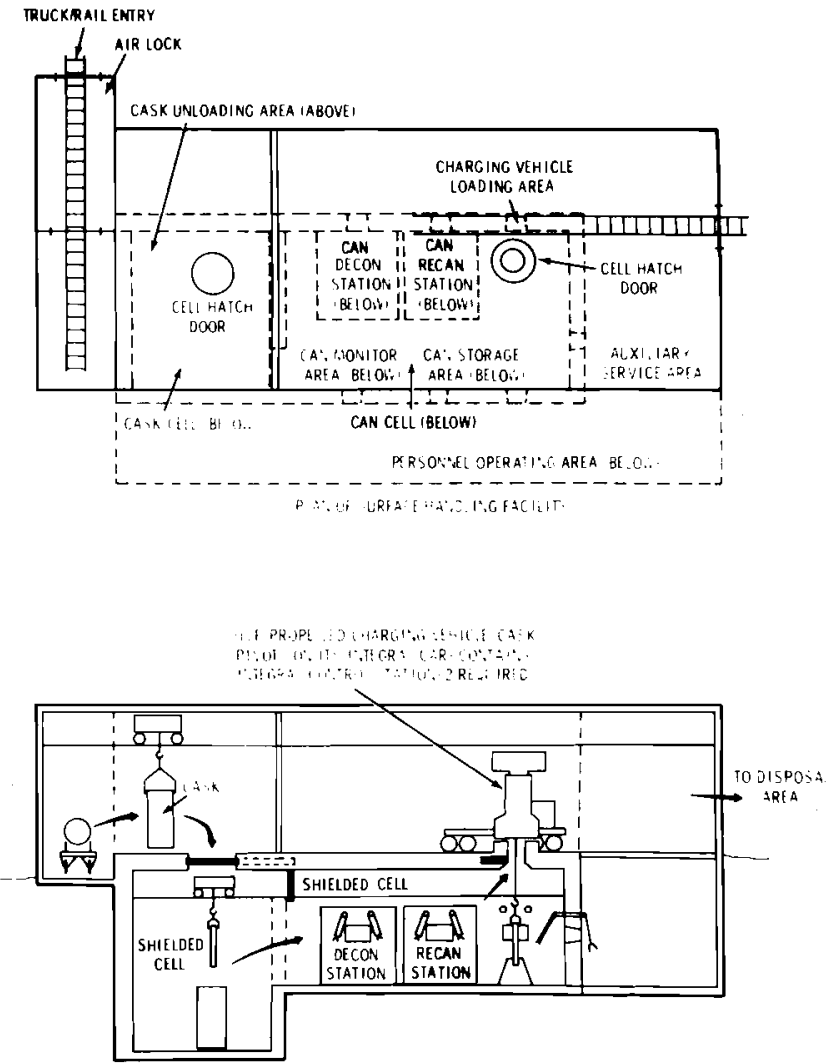

SECIIONAL EI IVATION THROUGH SUIRFACE HANDL ING FACII ITY

FIGURE 4.45. Conceptual Facilities for Solid Waste Emplaced in a Matrix of Drilled Holes

drives. Canisters are transported inside a lead-filled cask mounted on the vehicle operating platform. In addition to position read-out, instrumentation to indicate vehicle velocity, cable tension and elevation are installed at the operating console. Large, elaborate high-speed hoists, similar to those used on oceanographic research vessels, would be required for high capacity in deephole formations.

The surface shielded cell complex should be equipped with facilities for canister decontamination, inspection and recanning. Slightly negative pressures must be maintained in potentially contaminated areas of the unloading area-shielded cell complex. Exhaust ventilation air from areas confined in this manner is passed through prefilters and highefficiency filters before being routed to a stack that is continuously monitored for radioactivity. In addition to ventilation equipmént and provisions for back-filling and sealing, other required features include auxiliary service equipment and laboratory and office areas.

The characteristics of the concept for placing solid waste in a matrix of drilled holes are presented in abbreviated form in Table 4.28. 
TABLE 4.28. Summary of the Overall Characteristics;

Solid Waste Emplaced in Matrix of

Drilled Holes; No Fluid Cooling or Melting:

Waste Form

Waste Concentration

Operational Features

Candidate Geologic Environment

Retrievability

Monitorability

Extent of knowledge

Is olation

Possible Pathways to Man's Environment
High-integrity solid waste form and canister.

High in waste form; high to low when canister fails. Hole spacing is flexible.

Surface operations only. Relatively simple.

Might include intrusive igneous, crystalline metamorphic, or possibly shale or salt (bedded or domed) formations.

Moderately difficult for initial period (up to about 100 years); more difficult with time; might require overboring technology beyond current state-of-the-art.

Limited; can measure temperatures and released radioactivity within holes for limited time; can detect radioactivity in nearby water-bearing formations if it should occur.

Fair. Hole drilling is generally state-of-the-art. Exceptions are long-time proven cementing and casing systems and some hole diameter-depth limits.

Moderately deep to deep geologic isolation, 300 to 6000 meters, or nominal reasonable drilling depths. Depends considerably on effective manmade sealing of numerous manmade pentrations into holes.

Natural pathways such as fractures if flowing water present, volcanism, seismic activity, erosion, etc. Pathways attributed to man's actions such as drilling into repository, sabotage, etc. See also Volume 1 , Section 3 .

other

$--$

4.1.8 Solid Waste Emplaced in a Deep Hole - In-Place Conversion to a Rock-Waste Matrix

one method of placing solid waste in appropriate geologic formations is with the deep-hole concept. In this concept, holes about 16 kilometers in depth are drilled into a suitable geologic formation from the earth's surface. Solid waste is then disposed of in the lower portion of the hole. When the waste reaches a predetermined level, the hole is filled with sealant. Figure 4.46 presents the basic features associated with the deep-hole concept.

The base case for the concept incorporates melting of the waste and surrounding rock. However, the concept could be directed toward the nonmelting case if it is decided that in-place melting should not be permitted. Except for the need to reduce the heat dissipated to the rock, all the steps required for the nonmelting option are common to the melting case. The reduced heating load for the nonmelting case could be achieved by decreasing the can size, reducing the waste concentration while maintaining the reference can size, storing the waste for an interim period of time, spacing the waste canisters farther apart, or adopting a combination of these methods. A flow diagram depicting 


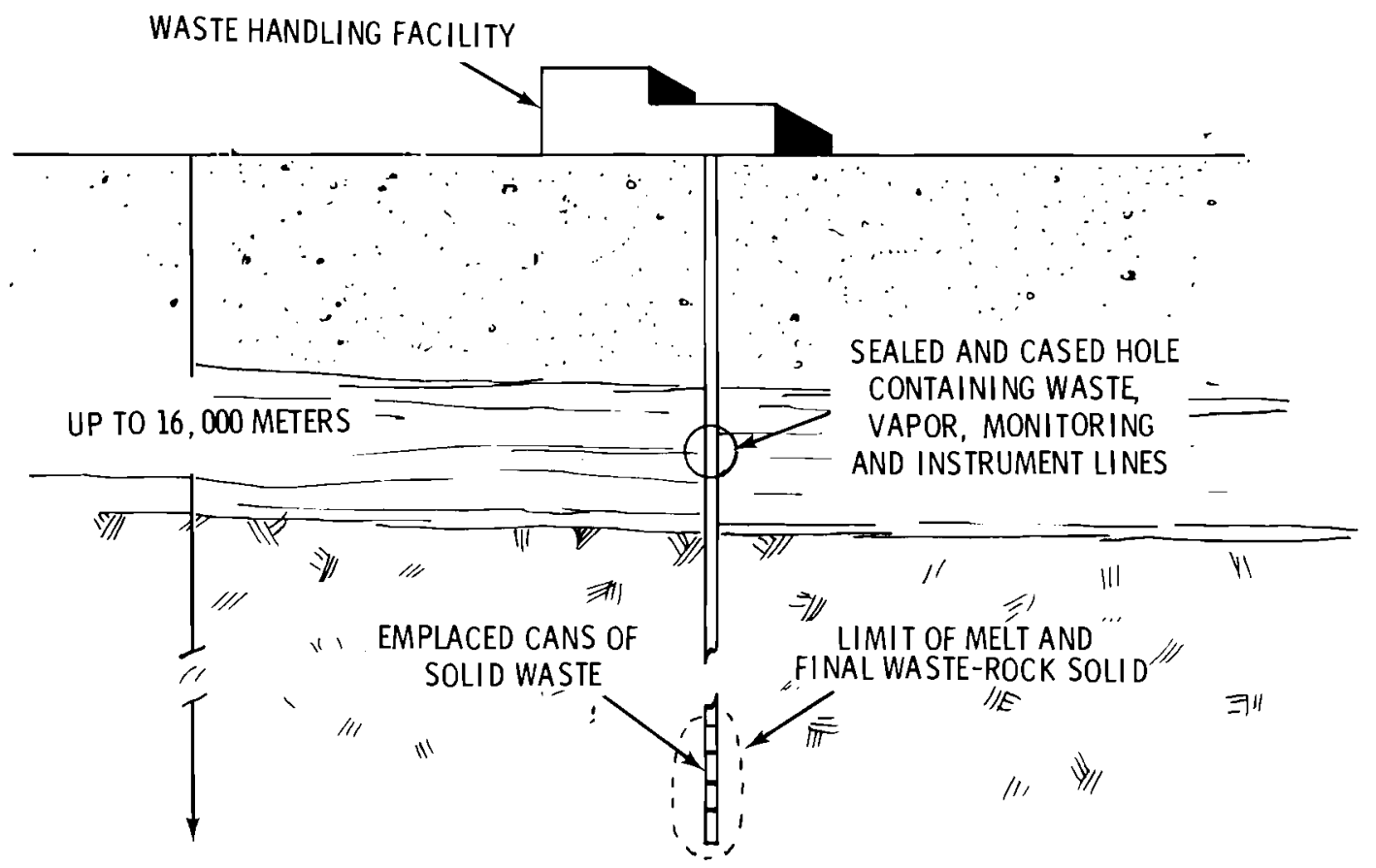

FIGURE 4.46. Solid Waste Emplacement in a Deep Hole with In-Place Conversion to a RockWaste Matrix

disposal by emplacing solid waste in a deep hole is shown in Figure 4.47 .

The concept incorporates a very deep drilled hole encased with corrosion-resistant material for the length of hole above the final waste level. For the reference example taken here, each hole would be capable of holding about four years waste from a 5 MT/day reprocessing plant (assuming canisters with diameter of 0.3 meters and length 3 meters). Waste is assumed to be disposed into the lower $8 \mathrm{kilometers} \mathrm{of}$ the 16-kilometer deep hole. For the reference case in this study, 2,500 canisters were assumed to be in the lower 7,500-meter portion of each hole requiring a total of six holes. The drilling operation of a single hole will require about six years using the largest rigs and equipment currently available.

The processes occurring within the hole, the facilities and equipment, and the resulting waste product form depend upon the waste type placed into the hole. For low-heat waste, no significant changes in the waste or geologic formation will occur. Drying of the rock, some small amount of gas release, and chemical reaction may occur from intermediate-heat source waste. Rock melting will occur for high-heat source waste. The total range of waste concentration could potentially take place at varying depths in the same hole. For example, below the level of the most recent canister addition would be solids which get progressively hotter with depth until melt- 


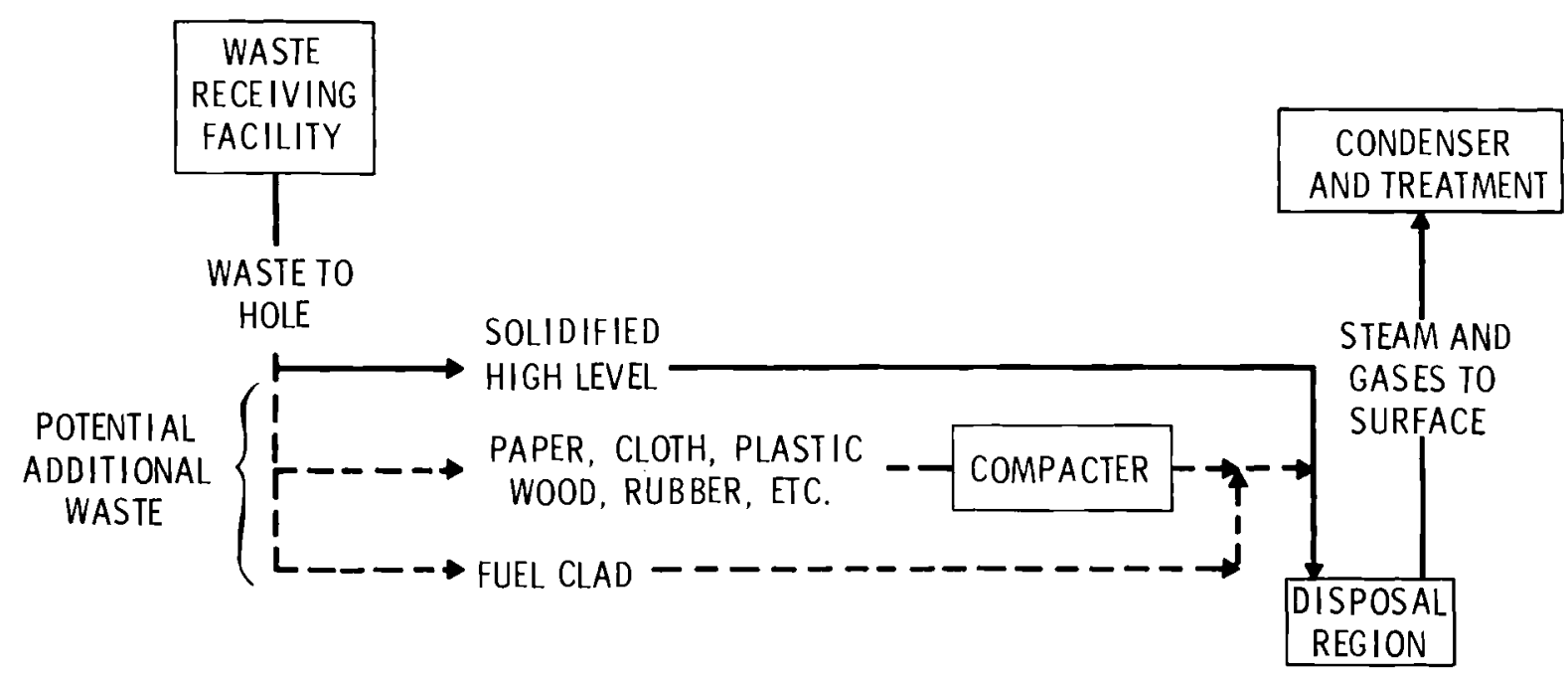

FIGURE 4.47. Flow Diagram for Solid Waste Emplacement in a Deep Hole

ing occurs. The melting forms a pool of melted waste, canisters, and rock. Below this melt level would be resolidified rock-waste melt. Chemicals can be added with the waste canisters if needed to control the chemistry of the final molten pool.

Addition of waste is discontinued when a predetermined level is reached, and the rest of the hole is then plugged with a sealant.

A concept of the key equipment within the shielded cell at the wellhead is shown in Figure 4.48. The main casing projects through the floor into the shielded cell. An intermediate-sized pipe and several smaller pipes are contained within the main casing. The interiors of all the pipes are accessible through covers in their tops. Access is for system needs such as inspection, monitoring, and repairs. The intermediate-sized pipe inside the large casing serves as a waste canister down-pipe and a steam outflow pipe.

The annulus between the large outer casing and the intermediatesized pipe is filled with a monitoring fluid to detect outward leaks from the inner pipe.

overall characteristics of the concept for placing solid waste in deep drilled holes are summarized in Table 4.29 .

\subsubsection{Liquid Waste Emplaced in a Deep Hole - In-Place Drying and Conversion to Rock-Waste} Matrix

One method for disposing of 1 iquid waste in appropriate geologic formations is in a deep hole. In this concept, holes about 16 kilometers in depth are drilled into a suitable geologic formation from the earth's surface. Liquid waste is then disposed of in the lower portion of the hole and converted in-place to a solid.

As shown in Figure 4.49, a very deep hole is drilled. The hole is encased with a corrosion-resistant material for the length of the hole above the final waste level. A shielded 


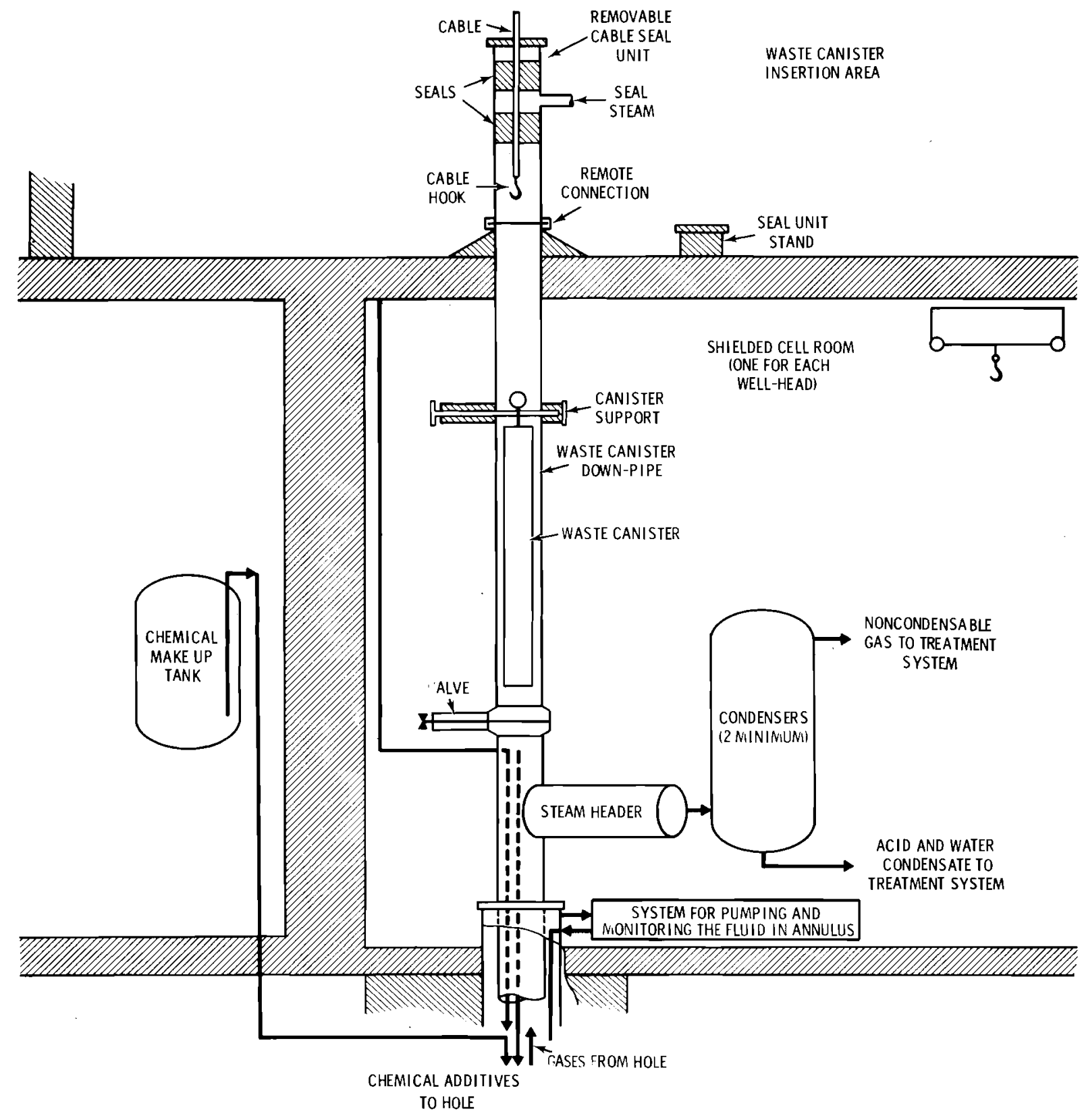

FIGURE 4.48. Facility Requirements at the Well Head Solid Waste Emplaced in Deep Holes with Melting 
TABLE 4.29. Summary of the Overall Characteristics;

Solid Waste Emplaced in Deep Holes; No

Fluid Cooling; Melting or Nonmelting:

Waste Form

Waste Concentration

Operational Features

Candidate Geologic Environment

Retrievability

Monitorability

Extent of knowledge

Isolation

Possible Pathways to Man's Environment

other
High integrity solid waste form and canister. Rock-waste matrix for melting case.

High in waste form; high to low when canister fails.

Surface operations only. Very difficult to drill to great depth.

Might include intrusive igneous or crystalline metamorphic formations.

Difficult for initial period (up to about 20 years); very difficult to nonretrievable thereafter. Requires overboring technology beyond current state-of-the-art.

Very limited; can measure temperatures and released radioactivity within holes for limited time; can detect radioactivity in nearby water-bearing formations if it should occur. Can monitor surface support.

Limited; hole depth beyond current state-of-the-art in many rocks. Melt-down and cooling knowledge is largely inferred.

Very deep geologic isolation from surface, below about 7000 meters. Depends partly on effective manmade sealing of moderate number of manmade penetrations.

Natural pathways such as fractures if flowing water present, volcanism, seismic activity, erosion, etc. Pathway attributed to man's actions such as drilling into repository, sabotage, etc. See also Volume 1, Section 3 .

Ability to control melt stage must be predicted before starting melt.

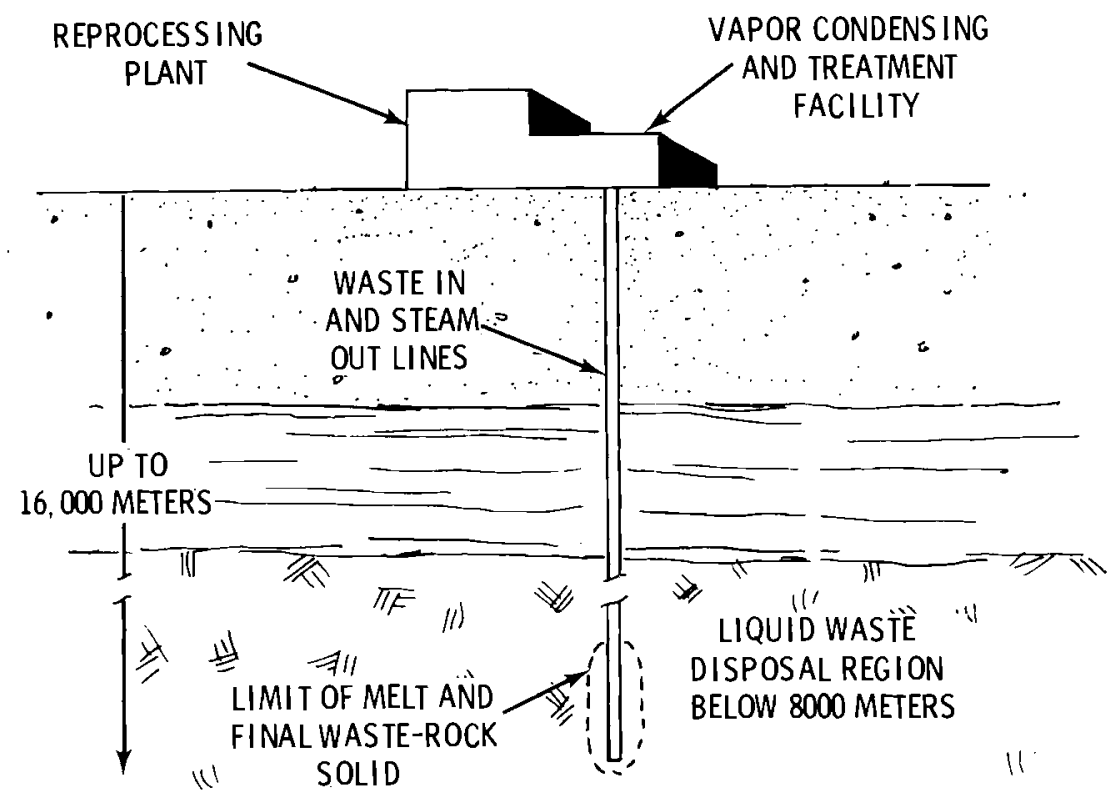

FIGURE 4.49. Liquid Waste Emplacement in a Deep Hole In-Place Drying and Conversion to RockWaste Matrix 
cell type of facility for processing volatile constituents issuing from the hole is located adjacent to the fuel reprocessing plant at the surface.

Aqueous waste is discharged from the nearby reprocessing plant into the deep hole. Steam and any noncondensable constituents generated by the boiling and drying waste are routed from the hole into the condensing facility. The waste boils to dryness shortly after it reaches the bottom of the hole. Hence aqueous holdup in the system is minimal.

In-place conversion of the concentrated aqueous waste to a solid will proceed in a continuous fashion at rising levels within the hole. Below the level of current liquid additions will be solids which get progresively dryer and hotter with depth until melting occurs. The melting is expected to form a pool of molten waste and rock. Below this level will be resolidified rock-waste melt. Within the boiling zone, the height of the aqueous portion of the waste column must be maintained at a controlled value to prevent surging of the $1 \mathrm{iq-}$ uid surface.

Addition of waste will be discontinued and the contents of the hole permitted to dry when a predetermined level is reached. This level is expected to be in the range of 6 to 10 kilometers below the surface. It is estimated that three deep holes are required to contain the waste produced by the reference reprocessing plant. When all the waste is dry, the remaining part of the hole will be plugged with a sealant and perhaps some rock backfil1.
The typical shielded cell facility requirements are basically the same as those for concept 5 , shown in Figure 4.41 .

The characteristics of the concept for placing liquid waste in a deep drilled hole with in-place drying and conversion to a rock-waste matrix are presented in abbreviated form in Table 4.30 .

\subsubsection{Liquid Waste Emplaced By Hydraulic Fracturing - In-Place Conversion to a Solid}

In disposal by hydraulic fracturing, liquid waste is mixed with dry solids to form a cement grout slurry which is then pumped down a well and out into a fracture or fractures in the subsurface rocks where the cementwaste mix hardens. For this concept, the reprocessing plant must be located at the waste disposal site.

Acting upon recommendations from a 1955 special committee of the Earth Science Division, National Academy of Sciences-National Research Council, a group from the American Petroleum Institute ${ }^{(125)}$ reviewed the technological problems associated with waste disposal in the earth, outlined the technology in use that might be adapted to disposal, suggested approaches to the problems and 1 isted related Research and Development requirements. One suggested method of disposal of low-level waste, hydraulic fracturing, was subsequently dedeloped and tested at Oak Ridge National Laboratory (ORNL). (126-131) From 1960 to 1966, seven experimental injections were made, involving a total volume of about 


\section{TABLE 4.30. Summary of the Overall Characteristics;}

Liquid Waste Emplaced in Deep Holes;

Initial Reflux Cooling; Melting:

Waste Form
Waste Concentration
Operational Features

Candidate Geologic Environment

Retrievability

Monitorability

Extent of Knowledge

Is olation

Possible Pathways to Man's Environment

other
Aqueous waste during emplacement; rock-waste matrix after in-place melting and solidification.

High as liquid; moderate to high as final solid.

Surface operations only. Surface vapor condensing and recycle system. In-place, self-conversion to melt; eventual selfcooling to solid.

Might include intrusive igneous or crystalline metamorphic formations.

Essentially not retrievable.

Limited; can measure some temperatures and released radioactivity within parts of hole for limited time; can detect radioactivity in nearby water-bearing formations if it should occur. Can monitor surface support.

Limited; hole depth beyond current state-of-the-art in many rocks. Melt-down and cooling knowledge is largely inferred.

Deep geologic isolation from surface, below about 6000 meters. Depends upon mobility of molten column of rock-waste; depends partiy upon effective manmade sealing of modest number of manmade penetrations.

Natural pathways such as fractures if flowing water present, volcanism, seismic activity, erosion, etc. Pathway attributed to man's actions such as drilling into repository, sabotage, etc. See also Volume 1, Section 3 .

Ability to control melt stage must be predicted before starting melt.

\section{2,500,000 1iters of 10w-level liquid} waste. Results of the experimental program were successful to the point that routine disposal of selected low-level liquid radioactive waste by hydraulic fracturing was begun in December 1966. Details of the hydrau1 ic fracture disposal concept developed by ORNL for disposal of lowlevel radioactive waste have been previously documented. (126-134)

Figure 4.50 shows the basic concept developed at ORNL as a radioactive waste grout sheet spreading laterally through an artificially created fracture in a shale bed. The total volume of waste that can be injected at any one site is determined by the lateral extent of each horizontal fracture and the vertical rise (uplift) of the overlying formations. Surface elevation measurements are taken after each injection. When the amount of vertical rise reaches a specified level that indicates no further horizontal injections can be made, the well is sealed and a new well drilled at another location. 


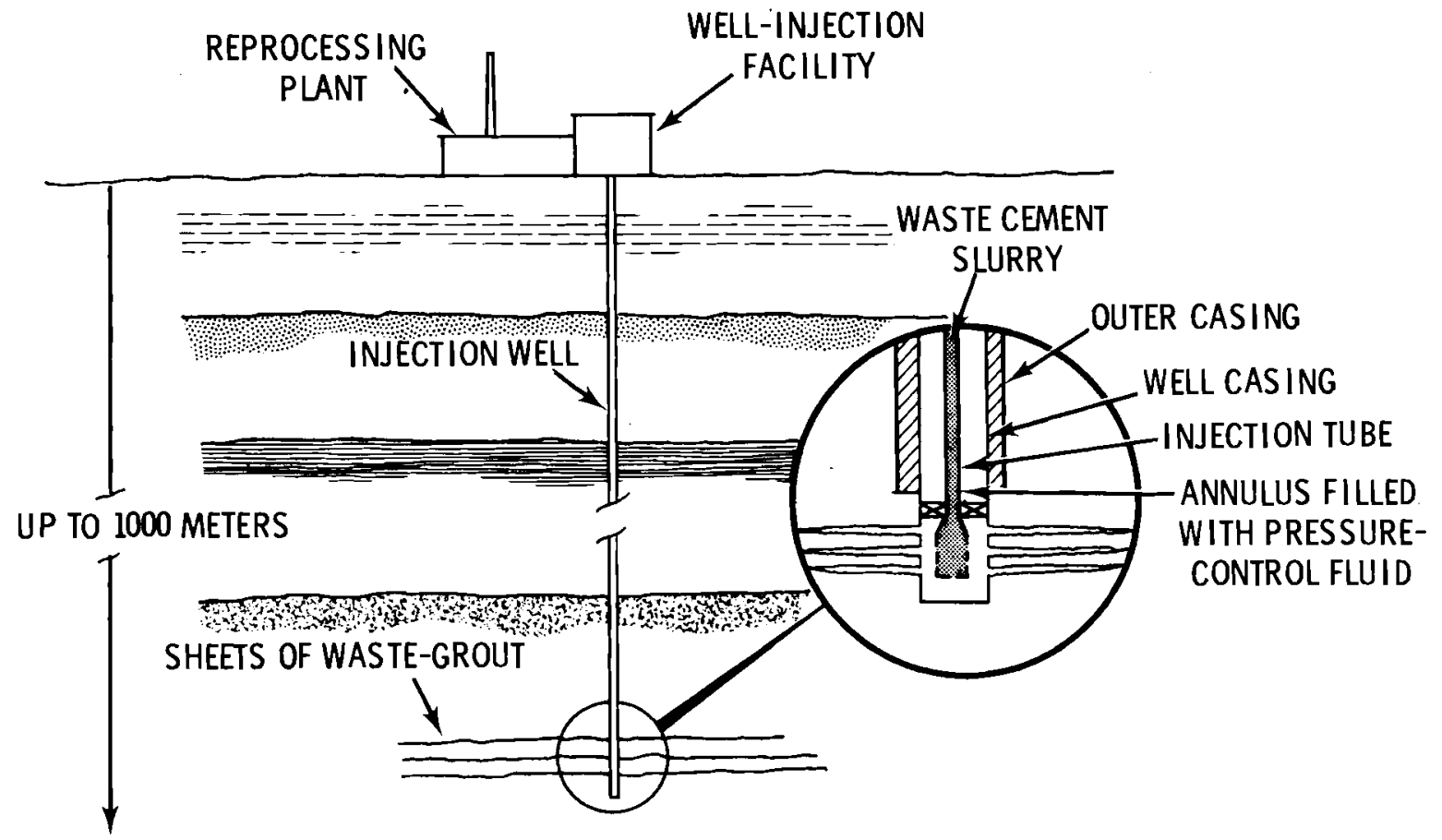

FIGURE 4.50. Liquid Waste Emplacement by Hydraulic Fracturing - In-Place Conversion to a Solid

Figure 4.51 shows the details of a typical waste injection well that might be drilled and prepared prior to disposal. (135) The cased well is prepared for injection by perforating the casing at the desired depth. The initial fracture is induced in the disposal formation through the well casing by pressurizing with water at about 130 atmospheres. Figure 4.52 shows a flow diagram where liquid lowlevel waste is mixed remotely in a shielded surface facility with preblended dry solids (principally cement). The resulting slurry then is pumped down the well and out into the disposal formation. The surface facility contains the shielded cells, which in turn contain pumps, mixers, injection head, storage tanks, etc.

Pumping pressure and rate of injection are sufficient to cause the performed fracture to extend and accept the waste-grout mix. Pressure is maintained on the waste-cement slurry while it hardens to form a thin horizontal grout sheet of about 3 millimeters thickness and 180 meters radius for each 300,000 liter waste batch. Subsequently, predrilled monitor wells are logged and precise surface measurements taken to confirm the emplacement position, distribution, and physical status of the injected waste. As soon as solidification has been achieved, in 8 to 24 hours, further disposal injections can be made by repeating the procedure successively at higher elevations up the well, thereby creating a stack of horizontal grout sheets. After the prescribed number of injections are made, the well is sealed. 


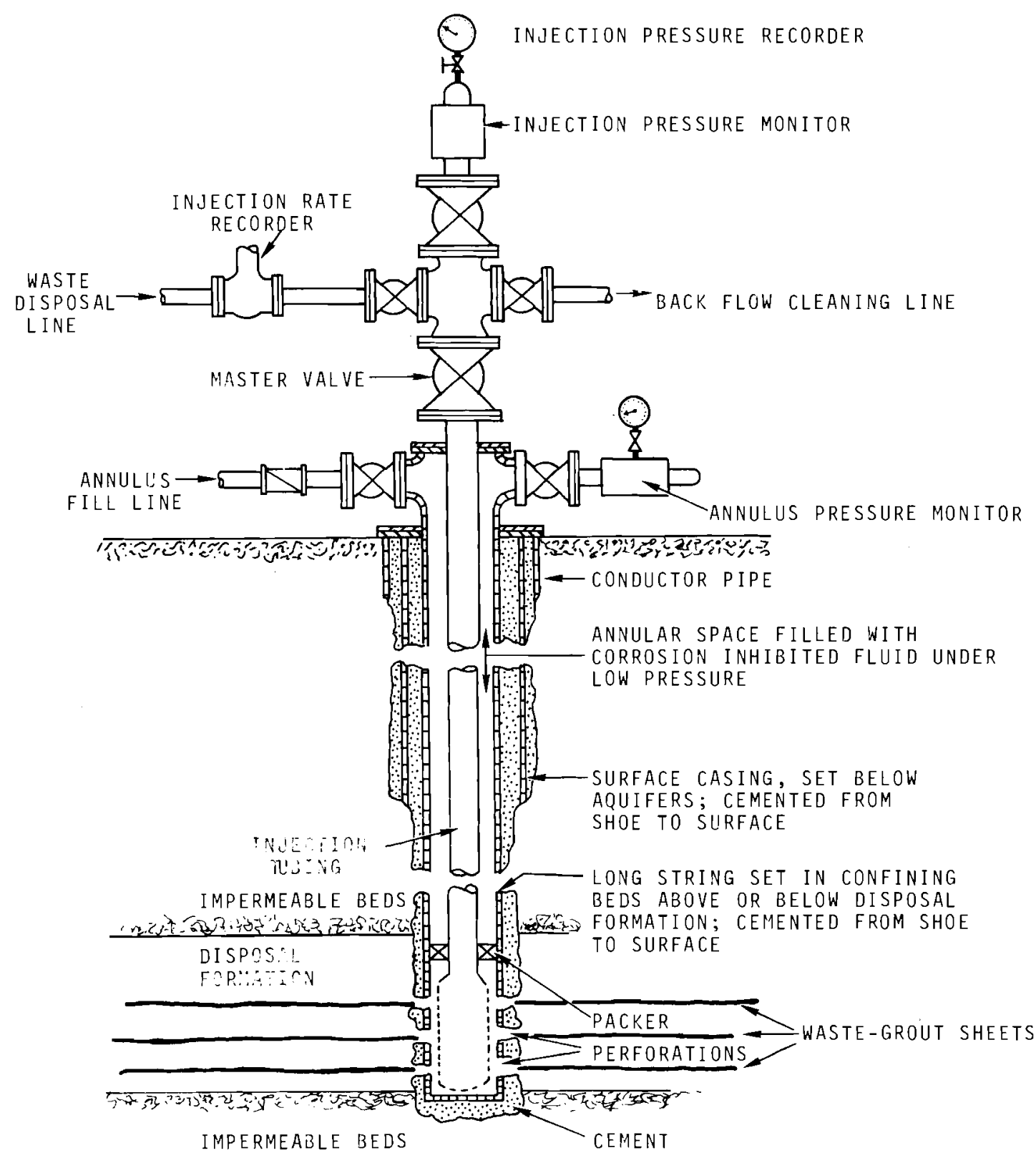

FIGURE 4.51. Waste Injection Well for Hydraulic Fracturing (Source: Reference 135) 


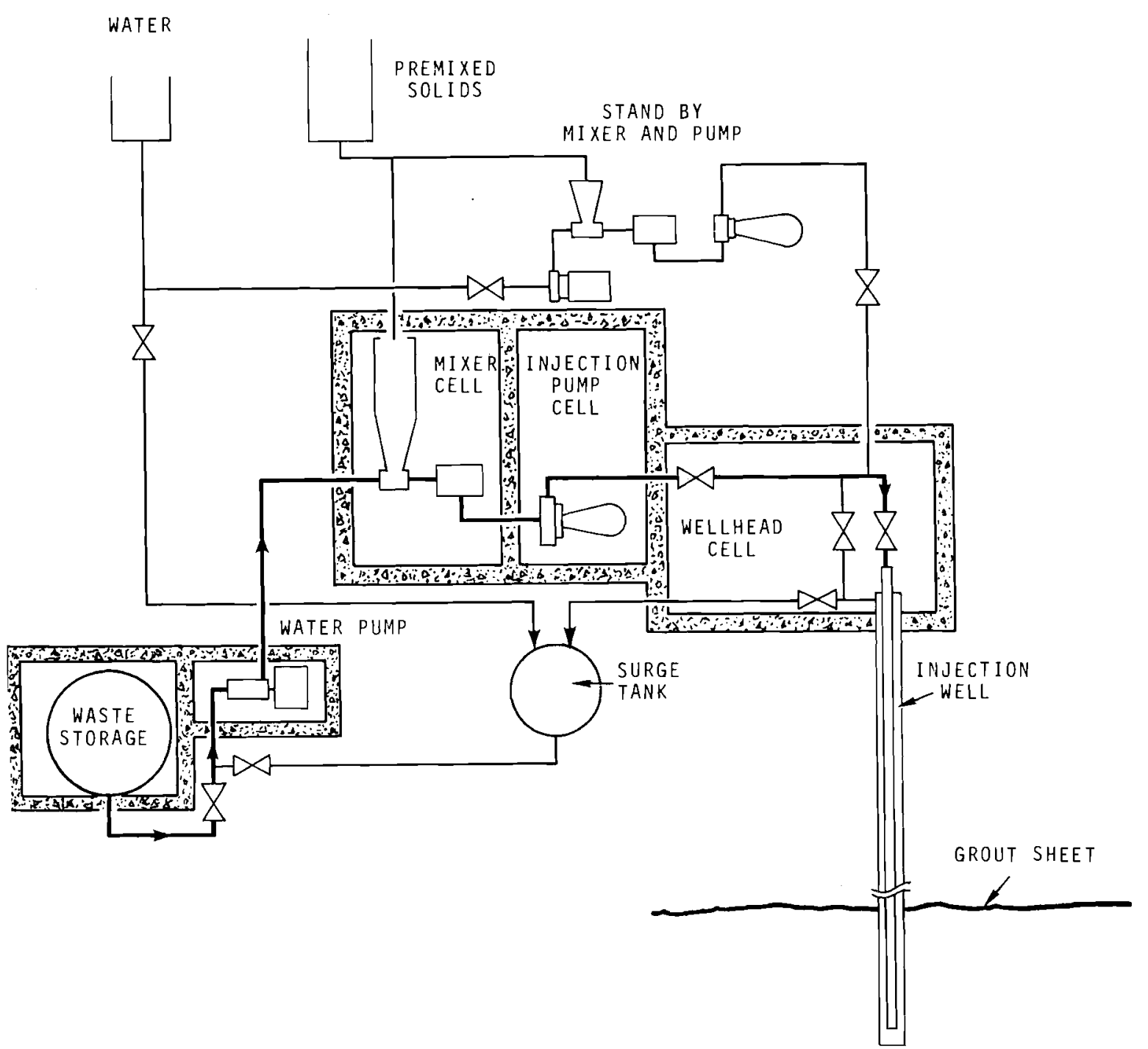

FIGURE 4.52. Flow Diagram of Surface system for Hydraulic Fracturing--Grout Mix-Waste Disposal (Source: Reference 131)

The volume of subsurface space required for disposal by hydraulic fracturing of all high-level radioactive waste expected to be generated by the year 2000 will depend primarily on the temperature rise that can be tolerated without affecting the physical properties of the hardened grout or causing release of natural fluids from the disposal formation. An additional limitation will result from the quantity of waste that can be mixed with the grout and still permit rapid solidification. For shales with a large amount of the clay mineral montmorillomite present, a comparatively large amount of water might be released if heated much above $100^{\circ} \mathrm{C}$. It is roughly estimated that the grout can safely contain up to about $40 \mathrm{Ci} / 1 \mathrm{iter}$ at a grout sheet 
spacing of 4.5 meters without reaching the $100^{\circ} \mathrm{C} 1 \mathrm{imit}$. Further evaluation of temperature 1 imits are needed before a concentration $1 \mathrm{imit}$ and distance between grout sheet layers can be more accurately defined.

Existing disposal operations at ORNL handle waste concentrations up to about $0.25 \mathrm{Ci} / 1 \mathrm{iter}$. With additional shielding of their present surface injection system, it has been estimated that radioactive waste concentrations could be readily increased to above $3 \mathrm{Ci} / 1 \mathrm{iter}$.

For a five-year interim storage period for the 1 iquid waste, the inventory of waste generated by a 5-MT/day fuel reprocessing plant operating 25 years will total about $2 \times 10^{4}$ megacuries. Assuming a di1ution of the waste into a slurry containing 40 curies per liter, a minimum volume of $5 \times 10^{8} 1$ iters would be generated for the reference fuel reprocessing plant.
Experience with the existing disposal facility at ORNL indicates that a minimum of about $1.5 \times 10^{7} 1$ iters of waste grout can be injected for each well with a high degree of assurance that a potential breach of containment will not occur. The maximum volume for injection cannot readily be calculated beforehand, but it is expected to be about $5 \times 10^{7} 1$ iters for the ORNL site, which is several times greater than expected for most potential sites. The spacing of the individual disposal wells would have to be approximately $1.5 \mathrm{kilometers}$ apart to preclude any uncontrolled added stress on the confining rock formation. For the reference case of $40 \mathrm{Ci} / 1 \mathrm{iter}$, a surface area of about 65 square kilometers, or about 8 kilometers on a side, would be required for disposal. Therefore it is essential that the maximum concentration of radioactivity be used to reduce the area for disposal. Table 4.31

TABLE 4.31. High-Level Waste Disposal by Hydraulic Fracturing - Waste Injection Data

\begin{tabular}{|c|c|c|c|c|}
\hline Concentration, Ci/liter & 0.25 & 3 & 40 & 100 \\
\hline $\begin{array}{l}\text { Waste volume per fuel } \\
\text { reprocessing site, } \\
\text { liters(a) }\end{array}$ & $8 \times 10^{10}$ & $6.7 \times 10^{9}$ & $5 \times 10^{8}$ & $2 \times 10^{8}$ \\
\hline $\begin{array}{l}\text { Injection wells per site } \\
(18 \times 1061 \text { iters } / \text { wel1 })\end{array}$ & 4,400 & 380 & 30 & 11 \\
\hline $\begin{array}{l}\text { Total injections per } \\
\text { well }\end{array}$ & 60 & 60 & 60 & 60 \\
\hline $\begin{array}{l}\text { Total area (kilometers }{ }^{2} \text { ) } \\
\text { wells on } 1.5 \mathrm{~km} \text { center }\end{array}$ & 10,000 & 850 & 65 & 25 \\
\hline
\end{tabular}

a. Data based upon reprocessing 45,625 metric tons of irradiated fuel and holding the waste for a five-year period. This is the waste from processing $5 \mathrm{MT} / \mathrm{day}$ of fuel for 5 years. Reprocessing this quantity of fuel will generate waste with $20,000 \mu \mathrm{C} i$ of radioactivity. 
summarizes the data for waste mixes with variations in radioactivity concentrations.

Overall characteristics of the concept of hydraulic fracturing and grout injection of high-level radioactive waste in geologic formations are summarized in Table 4.32.

\subsection{SYSTEM REQUIREMENTS FOR THE CONCEPTS}

Basic system requirements for the ten concepts are summarized in

Figure 4.53. This figure shows that in disposal of solid waste, optional interim retrievable storage of unconditioned high-level liquid waste arising from chemical reprocessing of spent fuels is expected to be followed by solidification and encapsulation; retrievable storage of the resulting canisters; transportation to the disposal site; and, finally, by emplacement in the geologic formation.

For most concepts to dispose of waste in the liquid form, the most likely anticipated path does not include interim retrievable liquid storage. The aqueous waste would be transported directly to the nearby disposal site by pumping the waste through pipes.

In the hydraulic fracturing concept, high-level liquid waste arising from the chemical reprocessing of "spent" fuels, after receiving some

TABLE 4.32. Summary of the Overall Characteristics; Liquid Waste Emplaced by Hydrofracture; In-Place Curing:

Waste Form

Waste Concentration Operational Features

Candidate Geologic Environment

Retrievability

Monitorability

Extent of knowledge

Possible Pathways to Man's Environment
Is olation

High-level liquid waste mixed with dry cement to form slurry during emplacement; in-place solidification 8 to 24 hours after injection.

Moderate as solid after dilution with cement.

Surface operations only on site of fuel reprocessing plant.

Expected to be suitable only in low permeability, thick, horizontal shale beds.

Essentially not retrievable.

Very limited; can measure initial spread of grout sheet; can measure some temperatures and radioactivity release for limited time; can detect radioactivity in nearby water-bearing formations if it should occur.

Technique of rydrofracturing well developed; each site will require extensive geologic study. Temperature effects of waste on host rock inferred.

Moderate depths of 300 to 1000 meters below surface provides primary isolation by impermeability of host rock. Secondary confinement provided by ion exchange capacity and cement waste form

Natural pathways such as fractures if flowing water present, volcanism, seismic activity, erosion, etc. Pathway attrib. uted to man's actions such as drilling into repository, sabotage, etc. See also Volume 1, Section 3 . 


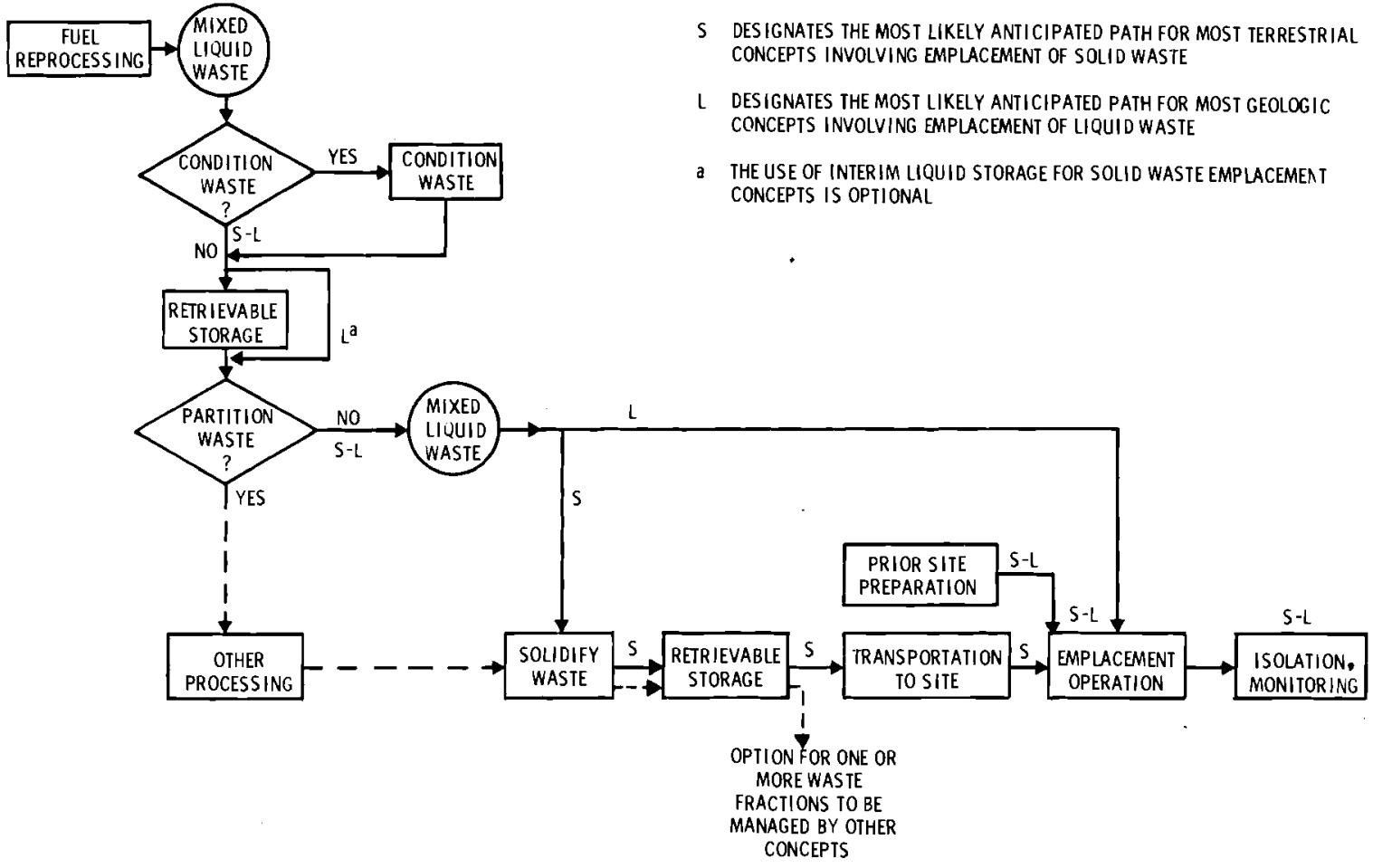

FIGURE 4.53. System Requirements for High-Level Radioactive Waste Management in Geologic Locations

conditioning, is sent to retrievable liquid storage, optionally allowed to age up to five years, and finally injected as a waste-grout mixture into a selected geologic formation. Since the high-level waste is liquid, the fuel reprocessing site must be 10 cated near the injection site.

Details concerning the specific system requirements of waste treatment and handling prior to emplacement at the disposal site, site preparation, transportation, operation of the site, and final sealing of the repository are presented below.

\subsubsection{Prior Waste Treatment and Hand 1 ing}

The anticipated needs for the concepts currently do not require any special reprocessing restrictions, chemical treatment of the waste such as neutralization, or chemical separations such as fractionation of the waste.

For solid disposal concepts the bulk high-level radioactive liquid waste is solidified and placed in canisters suitable for transporting from the reprocessing plant to the disposal site. Before final emplacement, retrievable storage of the canisters by alternative concepts is likely and could be done for time periods in the order of 100 years. Such storage will comply with present policy. Canister transport, repair, decontamination, and recanning could be required steps during such interim retrievable storage of the canisters. 
For concepts which dispose of waste in the liquid form, the bulk high-level radioactive liquid waste is supplied by the reprocessing plant. optionally the waste may be conditioned and stored retrievably by alternative concepts for an interim time period. Chemical adjustment, such as neutralization, and storage as liquids in tanks for up to five years are examples of these options. The waste could be chemically separated into an actinide stream and one or more fission product streams. Such separations may be desired to permit management of selected components of the waste (e.g., isotopes with short-or long-term biological hazards) by alternative concepts; to adjust heat generation rates; to recover useful constituents; also, in the case of hydraulic fracturing, to provide a compatible waste-grout-rock mix for a particular site. However, it was assumed in this study that all concepts have the potential to handle the total high-level waste without separation of waste constituents.

For hydraulic fracturing the primary waste treatment and handling steps expected to precede injection disposal would be interim liquid storage and liquid conditioning. Prior liquid storage would be highly beneficial to allow necessary heat decay. The maximum allowable heat level in the injected waste depends on the chemistry and physical properties of the host rock and the waste. The host rock chemistry determines to some extent the type of grout mix that can be used, which in turn will impact the conditioning required by the waste stream.
4.2.2 Site Preparation

The geology and hydrology of potential sites must be thoroughly investigated to assure that the requirements for waste disposal are satisfied. The existing knowledge of the geology and hydrology of each potential site must be studied and evaluated thoroughly at locations all around that of the proposed cavity. This information must be checked with information available from any existing nearby wells. New test holes would likely be required at the proposed site and at selected locations around the site to supplement available information on the hydrology and geology and to provide future monitoring capability. In addition, evaluations must be made of the geochemistry and potential chemical interactions between the host rock and the waste constituents. Detailed information about thermal and mechanical properties of the host rock will be required and thermal and mechanical models of the system developed and confirmed.

Site evaluation will include detailed analysis of population centers and densities, transportation facilities, and the potential for natural resources. The latter must include location and status of known resources and the potential for future resource development.

Additionally, for concepts involving disposal of liquid waste, the site must meet the requirements for a fuel reprocessing plant as well as for an underground disposal system because the concept involves disposal of the high-level waste at the site of the fuel reprocessing plant. It 
is assumed here that the basic site requirements for the fuel reprocessing plant (e.g., meteorology, seismology, geology, and hydrology, topography, demography, site exclusion etc.) are considered and that candidate sites meet these requirements.

Because the characteristics of the upper several thousand meters are relatively unimportant for the deephole concept, many parts of the United States that are mantled by layers ( 1 to $10 \mathrm{kilometers} \mathrm{thick)} \mathrm{of}$ permeable sedimentary rocks but are underlain by metamorphic or igneous rocks may provide suitable sites for the deep drill hole concept. The concept, therefore, offers the possibility of safe disposal of waste at or near processing plants where other suitable rock media may not be available at shallow or moderate depths.

The main requirements of a site for waste disposal by hydraulic fracturing are a suitable geologic formation at a reasonable depth that will fracture horizontally (or nearly so) under pressure. However, control by formational dip or bedding planes appears to be such an advantage in the forming of horizontal fractures that it may be desirable to restrict hydraulic fracturing waste disposal to thin-bedded formations such as shales. More massively bedded shale formations, mudstones and some volcanic rocks may be suitable in other respects and would be worth testing for horizontal fracture potential.

The site evaluations would be followed by site selection, design and general surface facility construction. Facility construction may in certain cases be preceded by the construction and operation of a pilot facility.

For concepts 1,3 and 4 (mined cavities) site preparation is basically similar: surface and underground facilities, drilling of monitoring holes, installation of monitoring equipment, and initial mining or drilling will be completed prior to the burial of the first canister. Subsurface facility construction would begin with drilling the main hole and excavating the tunnels. The tunnels would then be prepared structurally, cracks would be plugged, additional small holes radiating from the cavity would be drilled, and temperature and other monitoring instruments would be installed and back-sealed. Monitoring instruments would be installed and piping and instrumentation within the drill hole completed. The surface facilities would be completed and the piping and instrumentation connected to the below-ground facility.

Concepts 2 and 5 (involving wasterock interaction) resemble each other in site preparation requirements. Subsurface facility construction would begin with drilling the main hole and excavating the cavity. The cavity would then be prepared structurally, cracks would be plugged, additional small holes radiating from the cavity would be drilled, and monitoring instruments would be installed and back-sealed. The cavity liners would be fabricated and installed. Monitoring instruments surrounding the cavity liner would be installed and piping and instrumentation within 
the drill hole completed. The surface facility would be completed and the piping and instrumentation connected to the below-ground facility.

The site for concept 6 must be suitable for a 5-kiloton nuclear explosion carried out at depths typically more than 3 kilometers. Cavity formation would precede facility construction. One of the main holes would be drilled and the cavity produced by a nuclear explosion. The hole plug would be redrilled and the cavity checked for suitability. The second main hole is drilled if all cavity checks are affirmative.

Piping and instrumentation within the drill hole is to be installed and the surface facility constructed. The site is ready for operation once the surface and below-ground piping and instrumentation is connected. It is possible that the nuclear explosion must be completed before construction of the fuel reprocessing plant is permitted to start.

Concept 7 (matrix of drilled holes) would include in initial facility plans layout of the hole array. When the array was established, equipment would be assembled and the first set of holes drilled. After this, the concept has the same basic steps in site preparation as concepts 8 and 9. Surface facilities, drilling of waste disposal and monitoring holes, installation of monitoring equipment, and nonradioactive testing would be completed prior to burial of the first canister. It is expected that hole drilling, burial, and final sealing can proceed simultaneously in separate areas of the site after proof testing the system.
For Concept 10 (hydraulic fracturing) the preparation of the disposal site consists of drilling, casing, and testing for the disposal well. All monitoring holes and equipment installations will be completed prior to commencement of disposal operation. Each individual well disposal site may require a complete demonstration experiment using "nonradioactive" simulated waste. When conditions are considered satisfactory, a surface pipe would be connected to the radioactive waste in preparation for injection operations on a batch basis. A surface facility is needed for each well consisting of shielded cells for handling the highlevel waste. Surface hardware, shielding, and mixing facilities would be designed and installed. A backup storage system in the form of a tank (see Figure 4.52) would be installed to handle the aqueous waste contaminants which result from backflushing and cleanout of the well and equipment after each injection.

\subsubsection{Transportation to the site}

Waste solidification facilities or interim retrievable storage facilities and the disposal site are likely to be separated by large distances. Transportation to the disposal site would be accomplished by placing the canisters into massive, heavily shielded shipping casks weighing up to 100 tons. The shipping casks are then loaded onto special rail cars, trucks, or possibly barges for transportation to the site.

At the disposal site, transportation is accomplished by mechanisms such as cranes and shielded vehicles. 
The concepts for liquid disposal are considered to be applicable only on the site of a nuclear fuel reprocessing plant. Transportation requirements, therefore, would involve pumping aqueous waste through direct pipelines within the boundaries of the exclusion area to the surface facility above each well site. The pipelines used for transporting the radioactive waste to the repository would be heavily shielded and doublecontained.

\subsubsection{0peration of the Site}

Normal site operation can be initiated when construction is complete and the facility has been thoroughly tested and operated under simulated conditions to assure that all components perform as designed. Liquid waste concepts would initially require the addition of some water or nitric acid to the repository to bring the liquid volume to an operable level. Waste is then added over a period of a few months until steady-state boiling has started.

operation of the site can be categorized into waste receiving and handling; waste emplacement in the repository; and auxiliary or support functions.

Waste Receiving and Handling. Concepts for waste receiving and handling were developed in this study. This section treats those concepts for receiving high-level radioactive waste at the surface facility and the handling steps required prior to emplacement in the repository. Obviously, other concepts could be used, but those described here are believed to be representative of potential concepts.

Solid waste would arrive at the site by truck, rail, or possibly barge. Upon arrival at the site, the shipping cask and its carrier truck or rail car are moved via an air lock into the cask unloading building, which is equipped with cask cooling and decontamination equipment. A typical surface facility for handiing solid waste is presented in Figure 4.54. The cask atmosphere is sampled and the cask decontaminated if required. The cask is removed from its carrier and lowered into a shielded cell by a large, permanent bridge crane onto a cask transfer cart. The cart is used to move the cask below the hatch of a second shielded cell located above the first shielded cell. Individual canisters are removed from the cask by a remotely operated crane, inspected, repaired or recanned if necessary, and then transported to a transfer shaft where they are lowered by cable into the repository. The "surface" shielded cell complex is equipped with facilities for canister examination, decontamination, and recanning.

The steel cased and cemented transfer shaft is essentially an extension of the "surface" hot cell. The lower end of the shaft terminates in a transfer vault or shielded cell that is located in the geologic formation at the repository level. All manipulations in the "surface" and subsurface hot cells and the transfer shaft are conducted remotely using cranes, manipulators, and shielding windows. 

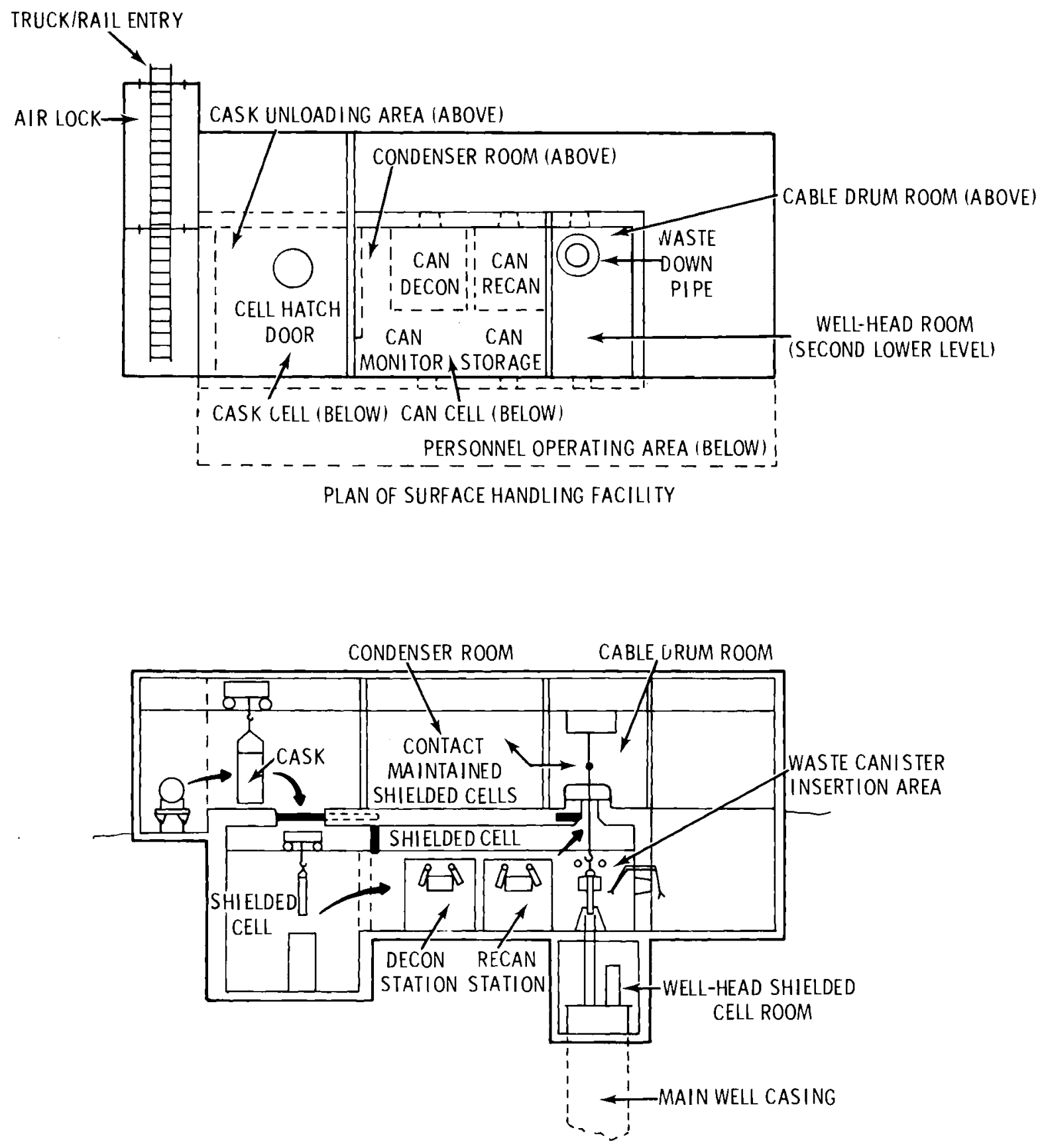

SECTIONAL ELEVATION THROUGH SURFACE HANDLING FACILITY

FIGURE 4.54. Surface Facility Layout for Receiving Solidified High-Level Radioactive Waste 
The matrix of drilled holes is similar to other solid waste disposal concepts except for use of a charging vehicle located in the surface facility. Canisters are received in the second shielded cell and, after inspection, lifted into the shielded cask of the vehicle for transport to the desired disposal hole. (See Figure 4.45.)

For a 111 iquid disposal concepts except hydraulic fracturing, liquid waste is pumped through shielded 1 ines directly from the reprocessing plant to the repository located in the geologic formation.

The essential components of a hydraulic fracturing disposal plant and their function are illustrated in the schematic flow diagram Figure 4.52. Each batch of approximately 300,000 1iters of waste is analyzed and a mix formulation established that will assure a pumpable slurry and a grout that will cure to the desired solid after injection. Prior to the injection, the dry solids are blended and temporarily stored at the site. After the equipment has been checked, the well is prepared by jet perforation at the depth and the fracture initiated using water at high pressure, 130 atinospheres.

Waste Emplacement. For solid waste disposal concepts 1,3 , and 4, individual waste canisters are moved from the subsurface shielded cell into a shielded transfer vehicle at the repository level. This transfer could be accomplished by lowering the canister onto a transfer cart, moving the cart horizontally by a built-in device, and raising it with a device which is part of the trans- fer vehicle, (see a graphic presentation of a typical subsurface facility in Figure 4.32). Upon receiving the canister, the subsurface transfer vehicle transports the waste package to its final storage location.

The vehicle used in Concept 1 is equipped with hoppers and mechanisms for backfilling the hole after the waste package has been deposited. The hole may be backfilled with crushed rock that was removed, with sand, or with some type of cement. In the event a waste canister fails, this backfill provides a partial barrier against escape of radionuclides into the tunnel area as well as providing some shielding to the tunnel area. After the last canister is placed in a hole, the top 1.8 to 2.4 meters of the hole are filled with a sealant to provide additional isolation and shielding.

After all holes have been filled and sealed, individual burial tunnels or rooms are sealed from the rest of the repository by a bulkhead. The tunnel or room may be backfilled immediately, at some later time, or perhaps not at al1; backfill could be crushed rock material previously removed, cement, a combination, or other materials.

The process for placing the pods and canisters described in Concept 3 is similar to concept 1. The main differences are: 1) the vertical travel of the shielded carrier must be greater to accommodate the finned surface extending above the tunnel floor; 2) the unwelded closure or lid must be placed inside the pod above the canister; and 3) the top 
of the pod must be sealed by a welded closure.

Concept 4 waste emplacement differs from Concept 1 only in that 1) cover blocks must be removed and replaced during emplacement of the canister, and 2) no backfilling of holes is required.

When placing waste canisters for final disposal in Concepts 2 and 8 , seals on the transfer shaft access port are opened and the canister lowered through the access port. Provision must be made for airlocks and cable seals to prevent gases generated down the hole from escaping at this time. The canister is lowered into the repository in a controlled manner to minimize damage to the canisters and the hole.

Routine operation of the system described in Concept 2 will involve either continuous or frequent batch addition of the canisters to the cavity, addition of recycle water to the cavity at a rate to maintain the liquid volume in the cavity at the desired level, and operation of the steam condensing and treatment system at the surface as long as cooling of the waste is allowed.

Canister emplacement is initiated in Concept 7 by moving the charging vehicle to the desired hole. The vehicle is accurately positioned over the hole. Any portable shielding required is moved into place and any couplings required for seal purposes are made. The hole sealing cap is opened and the canister lowered into the hole in a controlled manner to minimize damage to the canisters and the hole. The area surrounding and immediately above the canister may then be backfilled. The above processes are repeated until the hole is filled to the desired level. When the hole is filled to a predetermined level, the void space above the string of waste canisters is filled with permanent sealants.

Waste emplacement and routine operation of aqueous systems described by Concepts 5,6 and 9 will involve either continuous or frequent batch addition of high-level aqueous waste to the repository, addition of recycle water or nitric acid to the repository at a rate to maintain the liquid volume in the repository at the desired level, and operation of the steam condensing and treatment system at the surface as long as boiling aqueous waste exists in the cavity.

Referring to the hydraulic fracturing concept flow diagram, Figure 4.52, the dry solids and 1 iquid waste are vigorously mixed, at a constant flow rate, by the jet mixer. The slurry is then pumped to the wellhead, down the well, and out into the prefractured shale. After all the waste batch has been injected, a "nonradioactive slug" of water-grout is emplaced to partially clean the well. Pressure is maintained on the system until the grout mix has solidified (8 to 24 hours). (121) The system is then flushed and decontaminated as necessary. The jet mixer, the highpressure injection pump, and the wellhead are enclosed in individual radioactive processing cells to provide shielding and for ease in decontamination.

During injection operations, close monitoring of injection pressures is 
required to assure that vertical fractures do not form during injection. The waste-cement mix temperatures are monitored to assure that the heat limit of the mixture is not exceeded.

When the waste disposal limit is near for a disposal well, operations would be terminated, the well would be sealed, and a new disposal well and surface facility constructed at an appropriate distance.

Concepts $2,5,6,8$ and 9 permit melting of the waste and surrounding geologic formation resulting in a rock-waste matrix. When the decision is made to proceed with in-place fixation of the waste, drying of the repository contents is initiated by reducing the quantity of recycled condensate. The aqueous level gradually decreases in the repository until the liquid is evaporated. At some point before or during the drying stage chemicals could be added to the repository if needed to control the chemistry of the final molten pool of waste and rock. When the drying has progressed to a predetermined state, the drill hole and any other penetrations into the repository will be quickly sealed by a predesigned, high-integrity seal system and the steam condensing system will be shut down. Incomplete removal of volatile constituents from the repository before the final sealing should not pose a problem if the final repository pressure does not exceed lithostatic pressure.

After the repository is sealed, the waste will continue to melt, and over a period of tens of years the surrounding rock will melt to a predetermined extent. After 50 to
100 years the molten rock and waste will begin to cool and solidify. The time period required for solidification to be complete has not yet been calculated, but will likely be hundreds to perhaps thousands of years. During the melting and solidification periods the only operation required will be monitoring various conditions around the disposal area.

If it is decided that in-place melting should not be permitted, operation of the steam condensing and recycle system can be continued until the waste has decayed to a point that melting will not occur or until the waste is removed from the repository. Concept 5 permits most of the waste to be pumped to liquid storage facilities at the surface where it can be dealt with as desired. The sludge in the bottom of the repository is removed by slurrying and/or dissolution techniques. Depending on the extent of cleanout and decontamination required, final decontamination and restoration activities could be extensive.

Auxiliary or Support Functions. Auxiliary or support functions associated with emplacement operations include radiation monitoring, maintenance and repair of facilities, quality assurance control, security surveillance, engineering support, equipment decontamination and the management of any new waste that is generated.

Hole drilling and preparation is essentially a continuous operation for the deep drilled hole and matrix of drilled hole concepts because of the interaction between reasonable drilling rate, depth of the holes, 
and the number of holes required. Holes are drilled and casings set to the depth required. In-hole instrumentation is added and tests made to confirm that each hole is suitable for use. Each of the deep drilled holes may require up to six years for completion.

For all concepts, site monitoring will continue throughout normal operation and for some currently unknown time in the future but is expected to decrease in frequency as data are accumulated. Monitoring will involve measurement of radioactivity in monitoring holes surrounding the site and surveillance of the position and status of the repository. It may also be desirable to install temperature monitors in some selected holes. In addition, the site will be controlled with respect to other uses for a time which depends upon the long-term toxicity of the waste.

Monitoring may be carried out using radiation detection in smal1diameter cased wells to identify the position, extent and radioactivity of the solidified waste. Initial data would come from the recovered core of the test wells. Subsequently, the core holes could be logged with a variety of geophysical tools at regular intervals to verify the repository stability. Some monitoring wells would be drilled prior to the disposal as part of the site evaluation, some to monitor the disposal as it progresses and some for final evaluation. Each monitor well would be sealed when it no longer serves its purpose.

\subsubsection{Final Sealing from Man's} Environment

Final sealing of the waste from man's environment involves plugging the hole(s) into the waste-bearing area of the rock. Depending upon the particular disposal concept, isolation is provided by the waste form, waste canisters, and/or cavity linings as well as the geologic formation until final sealing is completed.

Sealing of the access hole to the waste will depend on a man-emplaced sealant. Sealing techniques used by the mining and drilling industry ( 81$)$ have only been demonstrated for the time range of about 50 years. These conventional sealants are generally forms of cements or clays.

\subsection{GEOLOGIC CONSIDERATIONS FOR SPECIFIC CONCEPTS \\ Viable concepts for disposing of} radioactive waste in appropriate geologic formations will be governed by the following geologic considerations to assure safe disposal and effective long-term containment of the waste:

- Thermal properties of the host rock

- Engineering properties of the host rock

- Water content of the rocks and water movement

- Mineral resources potential

- Geothermal resource potential

- Geographic characteristics

- Seismicity, and faulting

- Depth of disposal

- Dimensions of the host rock 
The following discussions of the above geologic considerations are of a general nature. Although general, information contained within the discussions is sufficient to allow identification of large geologic areas having potential for use as sites for disposal of high-level radioactive waste. After identifying specific candidate sites located within the larger areas all the geologic factors of the sites will be considered in great detail and examined with respect to the needs of a waste disposal site.

The most suitable rock media for the various concepts considered appear to be 1) intrusive igneous rocks (e.g., granite) or crystalline metamorphic rocks (e.g., quartzite) because of their low permeabilities and high mechanical strengths, 2) salt, either in stable domes or thick beds because of its low permeability and self-sealing property, and 3) tuff (welded volcanic ash) and shale because of their very low permeabilities and high ion-exchange capacities. No order of preference was established in this study, nor is it meant to be implied here. Sedimentary rocks other than shale and salt, and volcanic rocks, exclusive of tuff, are considered generally unsuitable for waste emplacement because of their potential for high permeabilities. Rock types which appear attractive for specific disposal concepts are enumerated in sections 4.0.3.9.1 through $4 \cdot 0 \cdot 3 \cdot 9 \cdot 5$.
The concepts based upon emplacement of liquid radioactive waste in underground cavities with in-place conversion of the waste to solids would have more stringent geological restrictions than those for solid waste emplacement concepts. The restrictions are needed because of (1) the higher mobility of the waste in its interim liquid form, (2) interim manmade barriers (a canister) are not present, and (3) the concentration of waste and its heat are significantly higher than for initially solidified waste.

An important consideration for emplacement concepts incorporating inplace conversion to a rock-waste matrix is whether or not extensive fractures will develop as a result of the expansion of molten rock due to radiogenic heat. Such fracturing may not extend far into the medium but provides some potential, nevertheless, for leakage to adjacent, possibly permeable, saturated zones. Also, there is some potential for geysering (expulsion of fluid material from the repository) resulting from the buildup of heat after final sealing of the hole.

A relatively large amount of information is available on the geology of conterminous United States. However, the knowledge of the geologic environment at great depth (to the order of 16 kilometers) is only inferred from geophysical measurements. Only a few drill holes have penetrated to depths of 9 kilometers and no drilling deeper than $9.3 \mathrm{kilometers}$ has been done. (136) 
Regulations governing the acceptability and operational safety of sites for handling radioactive materials are found in Code of Federal Regulations, Title 10 (1OCFR), Chapter 1, Part 20, "Standards for Protection Against Radiation"; 10 CFR, Part 50, "Licensing of Production and Utilization Facilities"; 10 CFR, Part 100, "Reactor Site Criteria"; and their appendices, in particular, Appendix A, 10 CFR 100, "Seismic and Geologic Siting Criteria for Nuclear Power Plants." In addition, guidance can be found in AEC Manual Chapter 6202, "Site Selection," Chapter 6203, "Site Development Planning," and their appendices.

\subsubsection{Thermal Properties of the Host} Rock

The rock thermal property of primary importance to radioactive waste disposal is thermal conductivity. Values for thermal conductivities of some potential host rocks are listed in Table 4.33 .

TABLE 4.33. Typical Thermal Conductivity of Potential Host Geologic Rocks

\begin{tabular}{lc} 
Rock & $\begin{array}{c}\text { Average Thermal Conductivity } \\
\text { millical/cm-sec }-{ }^{\circ} \mathrm{C}\end{array}$ \\
${$\cline { 1 - 1 }$} }$ & $9-19$ \\
Salt & $13-17$ \\
Granite & $6-9$ \\
Shale & $3-7$ \\
Tuff & $0.6-l^{(a)}$
\end{tabular}

a. Value estimated from similar materials
For all concepts a relatively high thermal conductivity of the host rock is desirable to efficiently and steadily dissipate the heat of radioactive decay from the chronic heat source. Good conduction of heat will generally allow for minimizing the extent of disposal areas and minimizing cost.

It is desirable for the melting point of the host rock to be greater than the melting point of the waste material. When the waste canister fails, a higher melting point rock would generally tend to minimize interaction between waste and the host rock.

For concepts with in-place conversion of the waste to a solid, the melting point of the host rock should be less than the melting point of the waste material to provide rapid incorporation of the waste into the host rock. The lower melting point would tend to mobilize the rock and promote interaction between the waste and the host rock. It may also be desirable to fill the space between the canister and the cavity with crushed host rock that readily melts and facilitates the waste-rock interaction.

\subsubsection{Engineering Properties of the Host Rock}

It would be desirable for the engineering properties of the host rock to be such that the open walls of the repository can be sustained with minimum additional structural support until the waste has been emplaced. In the case of mined cavities, safety considerations indicate strong desirability for competent rock with compressive strength greater than about 
$3 \times 10^{6} \mathrm{~kg} / \mathrm{m}^{2}$. (138) In the instances of deep drill holes or exploded cavities, the requirement is merely that the working remain open until waste emplacement. For disposal in salt, depths in the range of one kilometer evidently result in flowage at a rate that may be unacceptable without major additional structural support. At depths below $10 \mathrm{kilometers,} \mathrm{rock}$ properties are 1 ittle known. Certainly flowage of shale can be expected, and rock bursts will take place under many conditions in most rocks.

The host rock can be either massive or laminated $(138)$ as long as it is linear-elastic, isotropic and homogeneous. Isotropy and homogeneity imply uniformity of material and absence of defects such as joints or partings. All rocks generally exhibit some defects when mined. However, the host rock would generally be considered massive if the spacing between joints or partings is comparable to or larger than the critical dimensions of the cavities, or if the strength of the bond across joints is comparable to the rock strength. Typical rock types in the competent, massive elastic class are granites, gabbros, quartzites, massive marbles, jointed igneous or metamorphic rocks in which the joints are bonded, thick bedded sandstones, and limestones. The capability of the host rock to withstand thermal stress without significant new fracturing or extension of existing fractures must be demonstrated for any disposal scheme.

For deep drilled holes (Concepts 8 and 9), the principal geohydrologic requirement would probably be a thick sequence of rock with low permeability below a depth of about 3 kilometers. This requirement can probably be met in a variety of terranes. It would be even more preferable in a setting where such rocks (e.g., metamorphic and intrusive igneous rocks) persist from on or near the surface to great depths. These rocks have high mechanical strengths and therefore would present the least problems in maintaining the drill hole open during emplacement operations.

Deep sedimentary basins of interbedded rocks having varying degrees of permeability are generally not suitable for geologic disposal because of the higher potential for productive aquifers and (or) oil-bearing strata in the region above emplacement depths. Some basins at depths of about 9 kilometers or more may have such low porosities and permeabilities that they could be suitable for deep hole waste disposal, but this characteristic would have to be proven by exploratory drilling and hydraulic testing.

To be suitable for hydraulic fracturing waste injection (concept 10), it is generally considered that a geologic formation must produce essentially horizontal fractures under pressure. A fracture at any steeply dipping angle could represent a possible containment breach of the overlying strata and could lead to deposition of the waste-grout $\mathrm{mix}$ in a zone subject to leaching. Vertical fractures could also potentially open channel ways for circulating water and permit the leaching of grout which was originally beyond the reach of these waters. 
It is generally agreed that hydraulically induced fracture orientation is primarily controlled by the stateof-stress in the earth at the point of fracturing. $(139,140)$ In the $a b-$ sence of other factors, the primary fractures will always be oriented normal to the direction of least principal compressive stress. (139) horizontal fracture develops only when the vertical stress (overburden stress) is less than the two horizontal stresses. (139)

Results from the ORNL disposal of low-to-intermediate-level wastes by hydraulic fracturing indicates that horizontal fractures will follow bedding planes even with minor folding of a few feet. (126) Zero slope of a formation would be ideal but not controlling. Depending on the size of each injection, the maximum radius of the grout sheet would be in the order of 200 meters. If a 11 the points in the fracture horizon at the maximum distance still satisfy the requirements for isolation from potentially circulating groundwater, the amount of formation slope is inconsequential.

A reasonable estimate of the vertical stress component can usually be made from a knowledge of the depth and density of rocks at any particular point. Horizontal stresses are difficult to estimate, however, and practically impossible to measure with present technology.

Some fracture orientation may be controlled by the injection well operation. Stress concentrations around a well drilled in a stressed medium appear to favor elastic formation of horizontal fractures for a distance of about three diameters from the borehole. (138)

Oriented stress concentrations can also be effected by the control of well casing perforations. If a horizontal slot is cut in the well casing and the well pressurized, vertical tension shear stress will develop which in turn favors horizontal fractures. This influence will also die out rapidly away from the well unless otherwise controlled.

Petroleum industry experience using hydraulic fracturing as an oilwell stimulation technique indicates that vertical fractures will probably be more common than horizontal fractures at depths greater than about 1 kilometer. (130)

Although interpretation of the data is still mostly theoretical, there also appears to be a valid indication that vertical fractures will predominate over horizontal fractures under most conditions. $(130,142)$

Once a potentially acceptable disposal formation is identified, the question of total capacity for injected grout is difficult to determine with present technology. Each injection deforms the rocks slightly by uplift of the overlying formations. (126) Eventually, if injections continue, a failure could occur in the overlying surfaces that could represent a breach of the primary isolation. The most probable failure mode will be development of vertical fractures. Although the failure could be identified after it happens, present techniques have not been used to attempt to predict with certainty such a failure. $(133,142)$ 


\subsubsection{Water Content of the Host Rock}

Moisture available as free water, including connate water and fluid inclusions, should generally be as low as possible. Less than two percent available water by volume has been suggested in considering salt as the host rock for high-level radioactive waste disposal. (143) Higher water content should not necessarily exclude other rock formations as potential disposal media. For example, an average shale may contain up to about 12 percent water by volume but, in general, will have a very low permeability which greatly restricts water movement within the formation. Other rock types considered (e.g., intrusive igneous, cyrstalline metamorphic, and tuff) generally exhibit a free water content less than two percent.

Sites containing aquifers both active and potential in the disposal horizon, will be avoided for all the waste disposal concepts. However, in many locations unconfined aquifers may be encountered by shafts or drilled holes. Unconfined (water table) aquifers are those in which the water table is the top of the water-saturated material and the pressure at the top of this material is atmospheric. Depth to the water table may vary from less than a meter to hundreds of meters.

Confined aquifers may also be penetrated by the disposal operations. A confined aquifer is one where waterbearing material is confined above and below by impermeable material and the water is at a pressure greater than atmospheric. Confined aquifers may be found at any depth where the proper geologic conditions exist but generally are found at greater depths than unconfined aquifers.

Drilled holes and shafts which penetrate aquifers will be cased and sealed off to prevent movement of material into or out of the penetrations.

For the deep drilled hole concepts ( 8 and 9 ), the probability is small that much water will be encountered at depths greater than about nine kilometers, but this remains to be verified.

The hydraulic pressure within the disposal horizon should be equal to or less than the hydrostatic pressure of a column of water open to the atmosphere. If confined aquifers are present above or below the disposal horizon, it is desirable that the hydraulic pressure be less than or equal to the pressure within the disposal horizon. This condition indicates a higher degree of confinement in the disposal horizon than in the aquifer.

The water chemistry of any fluids present should be such that there is limited potential for undesirable chemical or physical reactions with the waste or containers. For inplace waste conversion concepts, the waste and the formation water should have chemical compositions that will assist in their interaction and precipitation of the waste constituents. The chemistry of essentially immobile formation waters reflects the chemistry of the enclosing rock masses. Hence, in this case, the rock will continue to provide those constituents that helped to initially precipitate the waste. 


\subsubsection{Mineral Resources Potential}

Mineral production inevitably involves some type of subsurface operation which could compromise the geologic confinement offered by any geologic waste disposal site. Areas of existing mineral production and significant exploration, therefore, should be avoided if possible. Any mineral in the host rock or formations above or below the host rock having obvious potential for economic development should be seriously considered as a threat to long-term geologic containment. Minerals such as clays or zeolites in the host disposal rock or in the formations overlying the disposal rock that can absorb radionuclides would be considered beneficial as long as the concentrations are low enough not to be economically recoverable. Any existing or abandoned mining or drilling operations and exploratory boreholes within the general area of a candidate disposal site represent potential hydraulic pathways between the host rock and man's environment. Consequently, all existing mines and boreholes should be located and evaluated as to their potential to form hydraulic connection to the disposal site. Where such penetrations exist, repairs may include reentry, cleanout, and replugging or sealing in a permanent and verifiable manner. (143)

\subsubsection{Geothermal Resource Potential}

As man's need for energy increases, the use of geothermal heat may become common and widespread. As with mineral potential, exploration or development of geothermal power poses a definite threat to the long-term integrity of any geologic waste disposal site.

Moreover, many areas and depths where the geothermal potential is significant are undesirable for waste disposal because of thermal and tectonic stresses and high temperatures. For periods in the order of hundreds of thousands of years, igneous (volcanic) action or reaction with volcanic fluids also is possible.

It can be shown, however, that unless the existing geothermal gradient for an area is well above average, it is doubtful that an efficient energy conversion could be made. (144) Therefore, it is believed that only areas with a geothermal flux greater than the general average value of $1.5 \mu \mathrm{cal} / \mathrm{cm}^{2} / \mathrm{sec}^{(144)}$ would be undesirable for waste disposal because of potential geothermal resource conflicts.

\subsubsection{Geographic Characteristics}

A site for disposal of high-level radioactive waste should be 1) as far removed from oceans and major lakes and streams as is practicable; 2) as far removed from human population centers as is practicable; and 3 ) in as gentle terrain as possible in order to avoid steep drainage gradients that could allow rapid distribution of any surface contaminants.

\subsubsection{Seismicity and Faulting}

The earth's crustal stability is of extreme importance when evaluating terranes for any waste disposal concept. Tectonic action could rupture the disposal zone and create 
passageways for groundwater to carry waste materials into man's environment: Therefore, all areas of high seismic risk (Zone 3) should be precluded from consideration. The selection of sites in other seismic zones would have to await seismic monitoring and detailed geologic mapping to establish the lack of fault systems or seismically active zones. With all other conditions comparable, sites with the lowest seismic risk would be preferable.

For the deep drilled hole concept low seismic risk is especially important during the operational stage. Several years are likely to be required for the actual drilling and preparation of a very deep hole and several more for disposal operations within a given hole. Even moderate earthquakes, if in close proximity to the drill hole, could cause premature collapse of the hole.

The emplacement zone of the repository should be virtually free of faults whether currently active or not. The location of any faults within the area of the site, the boundary of the buffer zone, and particularly inside the disposal cavity could be sufficient cause to abandon the site for disposal due to the potential for hydraulic or chemical transport of the waste material. Any fracture or jointing patterns that exist should be locally confined to the disposal cavity area and preferably oriented horizontally. Any vertical fractures or jointing must be shown not to extend continuously for a distance greater than about twice the cavity dimensions. This arbi- trary and possibly conservative proposed guideline would probably vary with each potential geologic host environment. The rationale for the proposed guideline is to minimize the potential for a permeable connection between the waste disposal area and man's environment. Horizontal permeability is similarly not desirable, but pathways to man's environment are generally longer in this direction. Therefore, higher permeability may be acceptable in the horizontal direction.

Great depth should contribute to self-sealing of faults. However, depth may not necessarily assure that faults and fractures will be closed and healed despite the knowledge that porosity and permeability generally diminish with depth. (71) Hydrologic testing at the Nevada Test Site revealed that fractures had low to moderate permeability at least to about 4200 meters (the maximum depth reached), (72) and fractures below six kilometers in a drill hole in the Delaware Basin of Pecos County in Texas were found to be permeable. Potential sites must also be carefully evaluated to ascertain the possible presence of buried low-angle or thrust faults. Areas known to be characterized by such faults or areas where they have been logically inferred should generally not be considered for deep disposal.

\subsubsection{Depth of Disposal}

Based on conservative judgment, a depth greater than 300 meters is proposed as a minimum to assure isolation from man's environment. In many 
localities important water wells already penetrate to depths of 300 meters and more. Where those conditions prevail or where excessive surface mass wasting processes such as erosion or denudation may occur, still greater depths may be the minimum a llowed.

The maximum depth for mined-out cavities is primarily a function of the temperature at which man can work. Greater depths can be used for other concepts not requiring human entry. With a surface temperature of $20^{\circ} \mathrm{C}$ and a typical geothermal gradient of $20^{\circ} \mathrm{C} / \mathrm{kilometer}$ a working temperature of $60^{\circ} \mathrm{C}$ would be generally reached at depths less than 2000 meters without artificial cooling.

Limiting conditions for other concepts are the maximum temperatures for accelerating or retarding wasterock interactions (whichever is desired), the physical and chemical conditions present, and, for the deephole, the ability to drill to suggested depths in the order of $16 \mathrm{kilo-}$ meters. At the greater depths, significantly different characteristics can be expected, including a much reduced possibility of sedimentary rocks, lower rock porosity, an increasing probability of at least low-grade metamorphism, and physical characteristics of the rocks. Depths of disposal for the concepts studied are presented in Table 4.34.

TABLE 4.34. Depth of Disposal
1. Solid Waste Emplaced in Mined Cavity -
Concept No Fluid Cooling or Melting
2. Solid Waste Emplaced in Mined Cavities - Interim Liquid Cooling and Conversion to Rock-Waste Matrix
3. Solid Waste Emplaced in Manmade Struc- tures in Geologic Formations - Interim Air Cooling
4. Solid Waste Emplaced in Manmade Struc- tures in Geologic Formations - Interim Water Cooling
5. Liquid Waste Emplaced in a Mined Cavity - In-Place Drying and Conversion to Rock- Waste Matrix
6. Liquid Waste Emplaced in Exploded Cavities - In-Place Drying and Conver- sion to Rock-Waste Matrix
7. Solid Waste Emplaced in a Matrix of Drilled Holes - No Melting
8. Solid Waste Emplaced in a Deep Hole - In-Place Conversion to a Rock-Waste Matrix
9. Liquid Waste Emplaced in a Deep Hole - In-Place Drying and Conversion to a Rock-Waste Matrix
10. Liquid Waste Emplaced by Hydraulic Fracturing - In-Place Conversion to a Solid
Depth, Kilometers

$$
\begin{array}{r}
0.3-3 \\
0.3-3 \\
0.3-3 \\
0.3-3 \\
1-3 \\
1-6 \\
3-6 \\
9-16 \\
9-15 \\
1+3
\end{array}
$$




\subsubsection{Dimensions of Host Rock}

The minimum acceptable horizontal dimensions of the host rock will depend on specific site analysis of several factors: 1) the total size and shape of the host rock formation; 2) the thickness and extent of any overlying rock formations; 3 ) the isotropy and homogeneity of the host rock; 4) thermal properties of the host rock formation; and 5) the hydraulic regime which will control any potential dissolutioning and waste transport. Therefore, minimum horizontal dimensions cannot be defined in simple terms. It is believed reasonable, however, for solid waste disposal to avoid areas where suitable host rock could not be demonstrated to extend to a radial distance of at least 500 meters from the boundary of the disposal cavity. One thousand meters horizontal distance is suggested for disposal of liquid waste.

Factors affecting vertical dimensions are discussed in Section 4.3.8.

A rock exhibiting a high degree of isotropism, homogeneity and massive nature would need to be less extensive to confine the waste. However, a rock mass exhibiting these characteristics will by its very nature be more continuous and thicker than one deviating considerably from that optimum. Desirably the total configuration of the rock mass should be defined, including its thickness, lateral extent, the nature and extent of overlying and underlying formations, the chemical and physical nature of the rock mass, and the hydrau1 ic regime within it.

\subsection{TECHNICAL FEASIBILITY}

The technical feasibility of the potential disposal concepts was determined in this study by responding to these primary questions: 1) Can the disposal concept be implemented using today's technology? That is, have we enough information to assess the overal1 development requirements? 2) Can the disposal concept be implemented with future technology based upon current theory? That is, is it theoretically possible? 3) Can the disposal concept provide the potential for confining or eliminating the waste over the time period of concern? only qualitative indications were developed for this study. 4) Does the concept have a favorable energy balance? (Is the energy consumed in implementation of the concept less than the electrical energy obtained?)

This study's responses to these questions regarding all the geologic concepts are summarized in Table 4.35.

Each element of systems requirements for implementing waste disposal by geologic emplacement (see Figure 4.53) was examined for technical feasibility. The elements were examined from the standpoint of utilizing existing technology as well as technology which could be developed in the future. All geologic concepts, with the possible exception of the very deep hole, appear to be technically feasible.

Studies to date indicate that technology permitting the emplacement of solid or liquid waste either is, or can be, established and that rock 


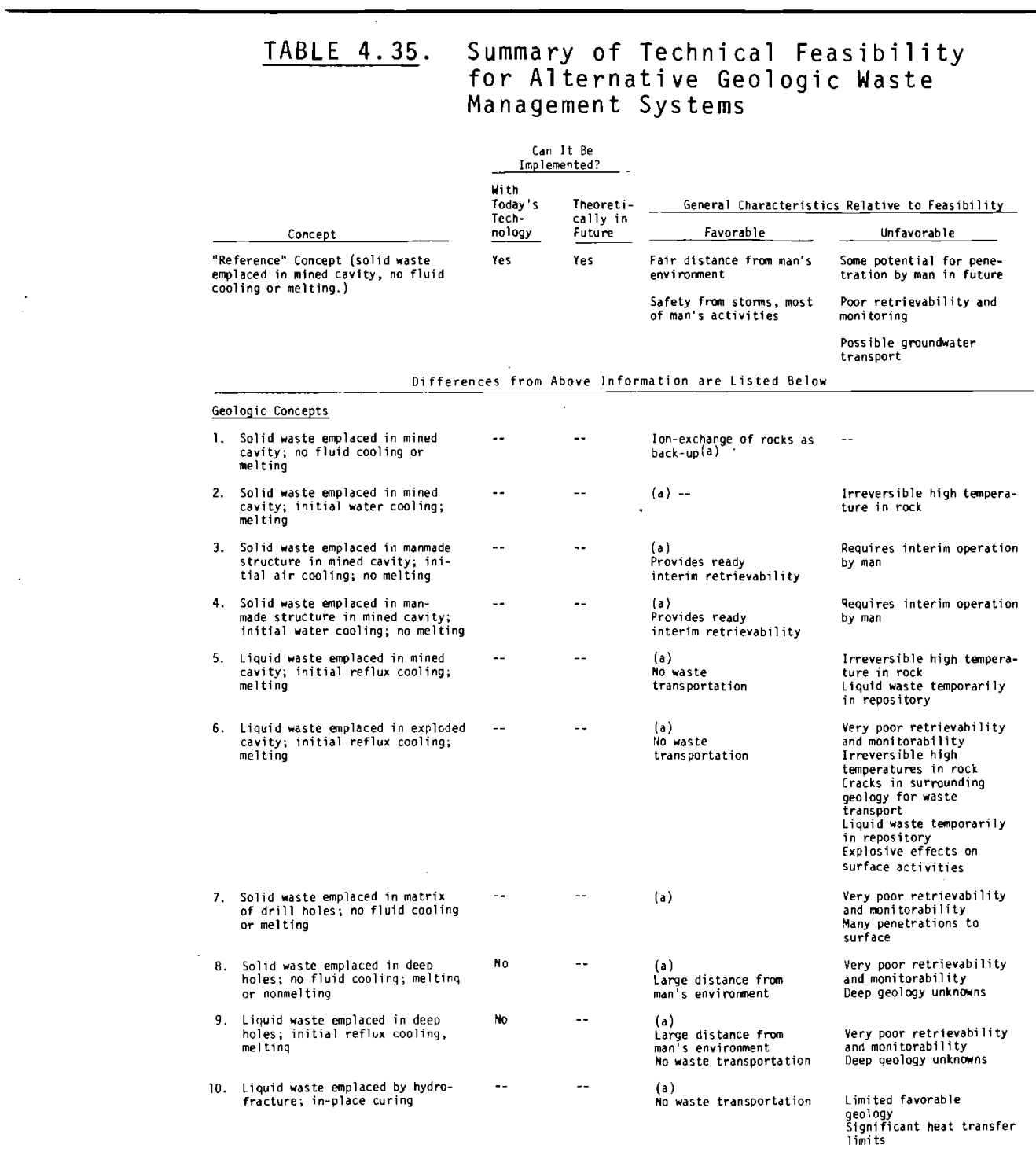
aj Ion exchange of soll-rocks as back-ud applles to all the
geologic concepts.

formations exist in geologic environments which should have the potential to provide confinement for long-time periods. No significant breakthroughs in technology are required for concept designs and no uncommon construction, mining or operational problems are anticipated except for drilling of a deep hole and allowing in-place conversion of waste to a rock-waste matrix.
Key elements pertaining to the technical feasibility of the potential geologic concepts to dispose of waste include the ability to: 1) store and retrieve both liquid and solid waste; 2) convert liquid waste to an encapsulated solid; 3) transport the encapsulated solids; 4) form the repository in the various candidate geologic formations; and finally 
5) emplace the waste in the repository.

The primary need in proving the feasibility of implementing the concepts involving in-place conversion is to assure the behavior of the waste and the molten rock from the time in-place conversion is started until the molten rock-containing waste is resolidified to its final form.

\subsubsection{Retrievable Liquid Storage}

Interim storage of the high-level aqueous waste, an option for all concepts has been used as a management technique in the U.S. since the 1940 's. The technology for storing high-level radioactive waste in tanks has been demonstrated, and continued improvement in tank design has proceeded to the point where latest designs are complex, double wall, steel vessels. $(145,146)$

High-level waste has been retrieved from tanks for further processing. Supernates and solids (precipitates) have been pumped and sluiced from storage tanks for recovery of cesium and strontium. $(147,148)$ Liquid waste has typically been stored from two to five years in stainless steel tanks prior to retrieval for fluidized bed calcination at the AEC's National Reactor Testing Station. (149)

\subsubsection{Solidification and Encapsula- tion}

Four solidification processes have been developed in the United States to the point of radioactive demonstration on an engineering scale: pot calcination, spray solidification, phosphate glass solidification, and fluidized bed calcination. (150,151) over seven million liters of liquid waste have been calcined using the latter process. (149) Encapsulation and remote sealing of canister caps by welding is an established operation. (152) solidification and encapsulation of the waste is described in volume 1 , Section 2 .

\subsubsection{Retrievable Solid Storage}

Prior to emplacement of solid waste in the repository, the waste canisters may be stored in a retrievable manner in some type of a surface storage facility. This interim storage will be accomplished using stateof-the-art techniques, i.e., using modular concrete structures with either air or water cooling to remove the heat resulting from radioactive decay or using individual sealed casks for each canister, stored in the open. Such storage could be done at the reprocessing plant and/or at a central repository. A Central Federal Retrievable Surface Storage Facility is currently being designed by Atlantic Richfield Hanford Company. (153)

\subsubsection{Transportation}

Detailed mechanical designs have not been developed for casks for shipping of high-level waste canisters. However, the technology that has been developed for the transportation of irradiated fuel elements can be directly applied to waste canisters. Irradiated fuel shipping casks are designed to withstand severe transportation accidents, including the damaging effects of impact, 
puncture, and fire. $(154,155)$ As stated in Reference $156 "$ "..There is no reason to believe that the performance specifications during accident conditions required by the Department of Transportation and the AEC cannot be met [for casks for the shipment of waste canisters]."

\subsubsection{Excavation, Operation and} Sealing

Present equipment and technological capabilities meet or exceed needed requirements for mining and drilling except possibly in the deep hole concepts ( 8 and 9 ). Suitable sealing techniques for the time periods required by the geologic concepts considered in this study have not been demonstrated.

Cavities have been constructed in a variety of geologic materials and of the sizes required by the mined cavity concepts ( 1 through 5 ). Cavity sizes range from the estimated 100 kilometers of 4.5 meters high by 4.5 meters wide tunnel required in Concept 1 to the approximately twentymeters-diameter sphere described in Concept 2. For any given depth below the surface, rock structural strength and temperature can limit cavity size and structural capabilities but are not expected to adversely influence the mined cavity concepts considered in this study.

Except for the deep drilled hole, holes of the sizes required for shafts (waste emplacement, ventilation, personnel access, etc.) have been drilled to the depths under consideration. $(157,105,158,79)$ The largest required is the 2.3 meters in diameter waste emplacement shaft for the $1.5 \mathrm{kilometers} \mathrm{deep} \mathrm{Concepts}$ 2,5 and 6 . Concepts 1,3 and 4 wil1 utilize 600 meters deep ventilation and personnel access shafts 1.8 meters in diameter. Waste emplacement holes of 0.4 meters in diameter by 4.5 kilometers deep and about 0.2 meters in diameter by 1 kilometer deep are used for the reference cases of Concepts 7 and 10 , respectively.

Drilling of a deep hole is beyond present equipment capabilities but should be achievable with extension of existing technology. It has been speculated that a deep hole such as required for Concepts 8 and 9 can be drilled unless unusual specific site conditions are encountered. $(157,78)$

Needed technological developments have not been acquired to permit drilling of deep holes due to the lack of commercial need for such a hole and hence the commitment to drill it.

For hydraulic fracturing (Concept 10), Oak Ridge National Laboratories development program has established the ability to form horizontal fractures.

Operating experience has proven the feasibility of handling highlevel liquid waste in piping and process equipment on a scale commensurate with those concepts disposing of waste in liquid form $(5,6,9$ and 10).(147,159) Also, technology for removing liquid high-level waste and sludge from storage tanks has been developed and demonstrated. $(147,159)$ This technology can be directly applied if it is decided to exercise the option of retrievable liquid storage or if it becomes desirable to 
retrieve liquid waste contained in the repository (Concepts 5, 6 and 9).

Wide industrial application has proven the technical feasibility of anticipated cooling techniques and the operability of required equipment needed for Concepts 3 and 4 . Additional study is required to prove the reliability, safety and maintainability of the cooling system in view of the possible disruption of cooling lines and ventilation shafts by rock movements.

Sealing techniques exist for drilling and mining procedures which are suitable at least for the short term, $(118,157,105,79)$ but adequate sealing for the long time periods considered here remains to be demonstrated.

The disposal of intermediatelevel radioactive waste by hydraulic fracturing has been studied and demonstrated by ORNL for more than 10 years. (134) Seven experimental injections involved a total volume of about 2.5 million liters of intermediate-level waste. ORNL's development program included: design and fabrication of a plant and equipment capable of safely handling the radioactive waste; chemical development of mix (waste-cement) formulas for maximum retention of radionuclides and for desirable slurry properties at minimum cost; and the development of techniques and instruments for monitoring the behavior of the fracture. With the technical feasibility of this concept generally established for disposal of low-level radioactive waste, significant technical breakthroughs are not needed for this concept to handle high-level waste.

\subsubsection{Energy Requirements}

Calculations indicate that the energy required for the drilling and excavating of repositories needed by the various concepts for burial of waste is at least five orders of magnitude lower than the electrical energy generated by the nuclear power plants that supply the irradiated fuel to the reference reprocessing plant. Calculated energy requirements for specific geologic disposal concepts are presented in Table 4.36 .

The calculated energy requirements, using information from References 160 and 161, are based on procedures currently used in the drilling and mining industries. The factors considered for the drilling operation were chipping of the rock by drilling, friction losses in pumping the mud, raising the rock to the surface, and ifting the drill string. For cavity formation the energy associated with powder hole drilling, blasting and rock removal were included in the calculation. Energy requirements for auxiliary operations such as ventilation, lighting, materials and personnel transport, etc., are not included but are estimated to be smaller than those for cavity forming. For drilling and excavating requirements of specific concepts, see Appendix 4.F on cost bases for geologic concepts.

\subsubsection{In-Place Conversion to a Solid}

Whether the concepts involving inplace conversion start with emplacement of solid waste (as in concepts 2 and 8) or 1iquid (Concepts 5, 6 and 9), it is necessary to assure the behavior 

TABLE 4.36. Estimated Engrgy Requirements For

Concept

1. Solid Waste Emplaced in Mined Cavity - No Fluid Cooling or Melting

2. Solid Waste Emplaced in Mined Cavities - Interim Liquid Cooling and Conversion to Rock-Waste Matrix

3. Solid Waste Emplaced in Manmade Structures in Geologic Formations - Interim Air Cooling

4. Solid Waste Emplaced in Manmade Structures in Geologic Formations - Interim Water Cooling

5. Liquid Waste Emplaced in a Mined Cavity - In-Place Drying and Conversion to Rock-Waste Matrix

6. Liquid Waste Emplaced in Exploded Cavities - In-Place Drying and Conversion to Rock-Waste Matrix

7. Solid Waste Emplaced in a Matrix of Drilled Holes - No Melting

8. Solid Waste Emplaced in a Deep Hole - In-Place Conversion to a Rock-Waste Matrix

9. Liquid Waste Emplaced in a Deep Hole - In-Place Drying and Conversion to a Rock-Waste Matrix

10. Liquid Waste Emplaced by Hydraulic Fracturing - In-Place Conversion to a Solid
Calculated Excavation Energy Requirements $\mathrm{kW}-\mathrm{hr}(\mathrm{a})$

$2 \times 10^{7}$

$2 \times 10^{7}$

$<3 \times 10^{7}$

< $3 \times 10^{7}$

$2 \times 10^{7}$

$2 \times 10^{7}$

$3 \times 10^{8}$

$3 \times 10^{8}$

$1 \times 10^{8}$

$2 \times 10^{5}$

a. Calculations are based on the excavation required for burial of waste from 25 years operation of a plant reprocessing 5 MT/day of fue 1 . This reference plant reprocesses fuel which represents $1 \times 10^{13} \mathrm{~kW}-\mathrm{hr}$ of generated electrical energy. For specific excavation requirements for each concept, on which these estimates are based, see tables in Appendix 4.F, Cost Bases.

of the waste in its geologic environment. Melting and cooling situations with waste, rocks, and related materials have been analyzed on a general basis. $(68,162)$ General behavior of heat sources in underground rock formations has been studied. (68) However, at this time it is not possible to assess the behavior of the molten mass in sufficient detail to conclude that concepts using melting as a method for ultimate solidification of the waste are technically feasible. Laboratory studies have shown that simulated waste, when mixed with rock and melted, forms a rock-like material. (163) But a detailed study is needed to establish with certainty the behavior of the molten mass within a geologic formation.

For in-place conversion concepts, waste and rock go through a molten phase and back to the final solid form. Cooling to a solid proceeds by natural cooling for several hundred years. Waste from 45,600 metric tons 
of fuel from the reference reprocessing plant would be incorporated in a volume of rock approximately equivalent to a sphere with a diameter of about 100 meters for the cavity concepts. In the deep drilled hole concepts the shape will be approximately cylindrical with a diameter of 3 to 10 meters. $(68,162)$ Such shapes will provide reasonably low perimeter surface-to-volume ratios.

Radionuclides will extend to the outer areas of the melted phase. For Concepts 2,5 and 6 , the resulting average concentrations of the fission product oxides are calculated to be in the order of 800 parts per million (ppm), and actinide oxides would be approximately $100 \mathrm{ppm}$. (164) Average radionuclide concentrations for concepts 8 and 9 are expected to be about twice as high. (164) variation of radionuclide concentrations will likely occur in the final solidified waste-rock product, with the tendency being for higher radionuclide concentrations in the center than at the perimeter. Some chemical separation of the radionuclides into zones of higher than average concentration could occur. It appears that most of the waste constituents would dissolve in most of the candidate rock types. Shale, clays, basalt, granite and feldspar usually melt to yield homogeneous silicate-based solutions and, when cooled relatively rapidly, form homogeneous glass-like solids. (165) Slow cooling will yield similar microcrystalline solids. The waste would generally be composed of oxides, and most of these oxides should be soluble in the melt. (165)
A specific example of molten rockwaste chemical conversion is found in the work reported by Isaacson, et al. (163) Simulated fission product nitrate salt cake was reacted with basalt at high temperatures to produce a "silicious rock-like material that is similar in gross chemical composition to basalt." It is concluded that the radionuclides should be tied up chemically within the rock matrix, although some concentration gradient may exist between the center of the melted volume and the outer areas.

The solid product remaining after cooling is expected to be a glasslike $(163,165)$ or microcrystalline material. When the melt cools, it will solidify as a single mass, and thermal stresses developed will probably be relieved by cracking. The chemical similarity of the wastecontaining rock to the natural surroundings should provide for minimized interaction with the adjacent rocks over long time periods.

\subsubsection{Potential for Retrieval of Liquid Waste from a Mined Cavity}

For the concept of liquid emplacement in a mined cavity, retrieval of aqueous waste from the cavity may be desired for reasons such as reprocessing to recover a product, to solidify and dispose of the waste by some other technique, or to accomodate an unforeseen failure or undesirable behavior. Retrieval of the aqueous waste could be accomplished using extensions of present techniques after start-up if it were determined that 
the aqueous waste must be recovered from the mined cavity. Full retrieval would require relatively complicated sludge removal and/or dissolving operations because of accumulation, settling, and "cementing" of solids in the aqueous waste. Complete decontamination of the liner and piping after removal of all the waste would require considerable additional operations.

The liquid portion of the waste could be blown or pumped out at any time during the life of the plant $(147)$ if retrieval were desired. At Hanford, high-level liquid waste is routinely pumped out of near-surface tanks and to and from processing plants and other tanks. $(81,159)$ The liquid phase has been pumped out at rates on the order of 600 liters/ min. (159) The primary limit on rate is pump and pipe size. (159)

Radioactive siurries have also been pumped out of waste tanks, using specially developed equipment and procedures. (159) significantly less sludge is expected from acid waste which is boiling (the most likely option here) than for aged and nonboiling neutralized waste as handled at Hanford. $(147,159,166)$ The sludge removal technology is well summarized by Larson $(147)$ for the Hanford wellcooled alkaline waste sludges which range in age from 5 to 25 years old. Special oil well pumps exist in types which appear to be applicable for liquid waste and slurry pump-out, such as one with a capability for 60 liters/min of flow from depths of 3 kilometers. (81)

\section{$4.5 \quad$ SAFETY}

Safety is a major consideration in decisions on the use of any potential scheme for disposal of radioactive waste. An acceptable disposal option must provide protection during operational phases and provide the necessary isolation during the long time periods of the disposal phase.

A quantitative measure of safety has not yet been developed in this study. However, the methodology has been developed and preliminary evaluations are in progress. The methodology is described in section 3 , volume 1 of this report. The methodology involves calculating probabilistic risk to man by estimating consequences of potential radionuclide releases to man and multiplying these times the estimated probability of radionuclide releases. Failure mode analysis using fault trees is used to identify mechanisms for failure of the waste disposal system. A preliminary generalized fault tree which can be applied to geologic disposal concepts was developed, and sample calculations of risk were made for one series of failure events to demonstrate the methodology for evaluating concept safety. The sample calculations, given in section 3 , indicate the potential risk to man from the one failure sequence for solid waste burial in a mine cavity to be in the order of $10^{-14}$ to $10^{-10} \mathrm{mrem} / \mathrm{yr}$ during the operational period, $10^{-10}$ to $10^{-6} \mathrm{mrem} / \mathrm{yr}$ at 1000 years after disposal, and $10^{-6}$ to $10^{-3} \mathrm{mrem} / \mathrm{yr}$ at $1,000,000$ years after disposal. However, the calculations are on $7 y$ 
for a hypothetical case and cannot be used quantitatively.

In the fault tree developed for geologic disposal, a total of 77 basic failure events shown in Table 4.37 was identified as possibly contributing to release of waste from a geologic disposal site. Many of these events are common to all the geologic disposal concepts studied, as shown in Table 4.37 Those failure events which are not applicable to a given concept are identified by the letter $\mathrm{N}$.

Information presented in the table is not indicative of the relative safety of the concepts since all failure elements do not have the same importance. In addition, it is expected to be shown through further study, that many more failure events are not applicable to a particular geologic disposal concept. Thus, the list shown in Table 4.37 cannot be used to judge various concepts. The information does, however, identify the potential failure elements which must be considered in order to evaluate the safety of each geologic disposal concept. Additional information on the fault tree study and on the various failure mechanisms is given in section 3 .

As the result of sorption of radionuclides by rocks, certain geologic formations will, in the unlikely event of ground-or surface-water intrusion, significantly reduce the consequences of such an event. Radiological consequences of a postulated release incident, with and without removal of waterborne nuclides by sorption, were discussed in Section 4.0.4.

\subsection{RESEARCH AND DEVELOPMENT NEEDS}

Although all geologic disposal concepts were found to be technically feasible, they all need Research and Development for their implementation. Research and Development needs (i.e., scope of studies, cost, and time requirements) were estimated for each of the 10 geologic concepts studied, assuming they would be selected for the ultimate disposal concept, and assuming no findings would be uncovered which would negate the concept. Research and Development needs are primarily associated with the analysis of past and future geological events, the definition of the effects resulting from the emplacement of the waste in an underground repository, development of specialized waste emplacement techniques, and cost optimization of concepts involving large amounts of drilling or excavating. Except for the deep drilled hole concepts, design and construction of a repository complex should not involve serious technological problems. Additional objectives of Research and Development studies are the quantitative definition of effects of heat and radiation on the geologic environment, the evaluation of events that could impair confinement integrity, and the behavior of the system if in-situ waste fixation by wasterock melting is involved. The major consideration is the investigation of any mechanisms that could cause protective rock structures to fail to the extent that ground-or surfacewater could enter the repository and 
TABLE 4.37. Basic Geologic Disposal Failure Events Identified by Fault Tree Analysis

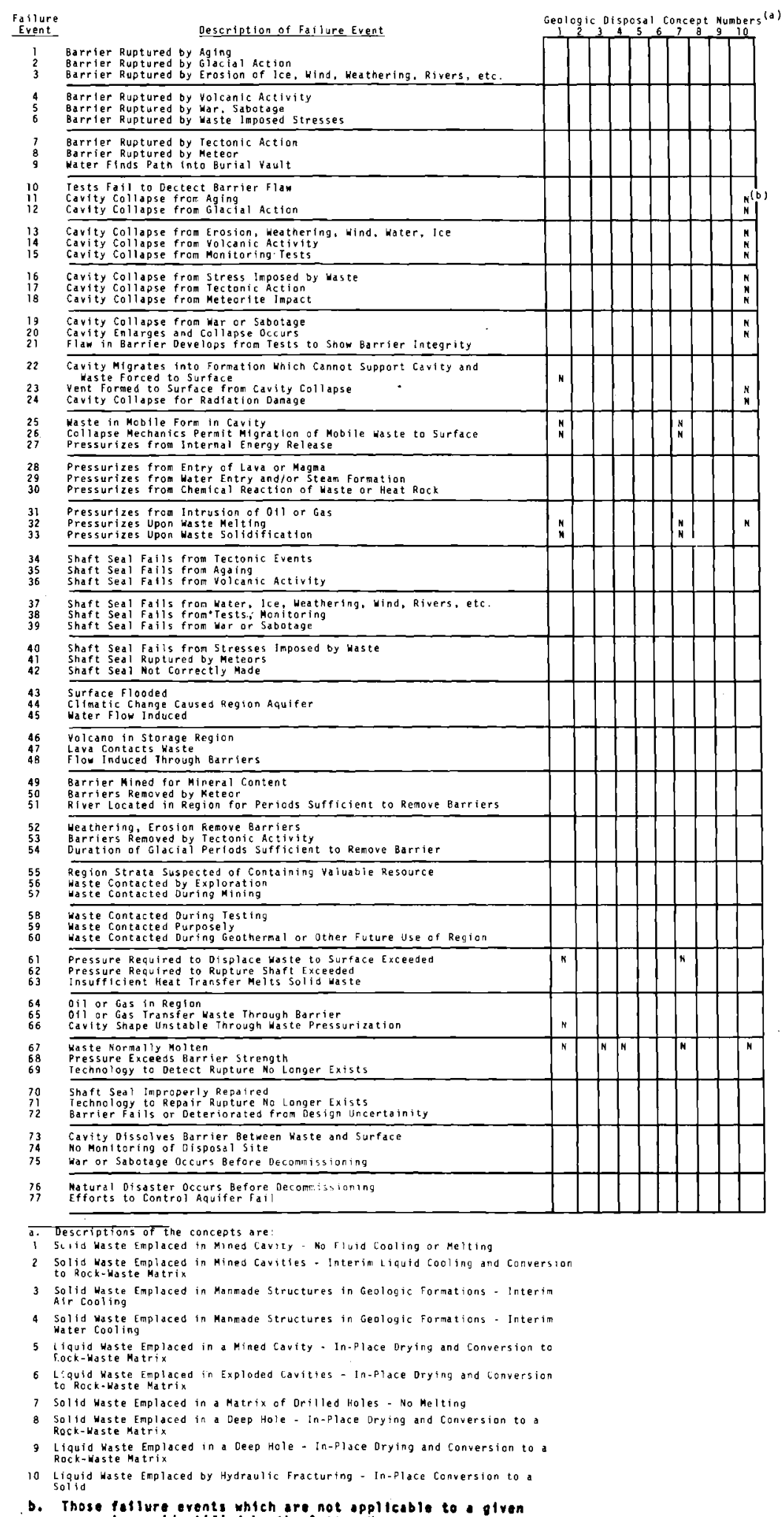

b. Those fatlure events which are not opplicable to olven 
transport waste constituents into man's environment. Substantial experimental and evaluative efforts are currently under way concerning the development of a mined cavity repository in bedded salt. (124) There has been much less effort associated with other potential geological environments, and considerably less is known about their suitability for waste disposal.

Total estimated Research and Development time and funding require- ments for individual disposal concepts are summarized in Table 4.38.

Estimated Research and Development costs range from 50 to 180 million dollars. Concepts $1,3,4,7$ and 10 are at the low end of the range because extensive Research and Development efforts performed to date on similar disposal methods (e.g. mined cavities in salt formation and emplacement of intermediate level radioactive waste by hydraulic fracturing) have produced information

TABLE 4.38. Estimated Research and Development Needs and Timing to Routine Operations for Geologic Disposal Concepts

\section{Concept}

1. Solid Waste Emplaced in Mined Cavity - No Fluid Cooling or Melting

2. Solid Waste Emplaced in Mined Cavities Interim Liquid Cooling and Conversion to Rock-Waste Matrix

3. Solid Waste Emplaced in Manmade Structures in Geologic Formations - Interim Air Cooting

4. Solid Waste Emplaced in Manmade Structures in Geologic Formations - Interim Water Cooting

5. Liquid Waste Emplaced in a Mined Cavity In-Place Drying and Conversion to RockWaste Matrix

6. Liquid Waste Emplaced in Exploded Cavities - 170 In-Place Drying and Conversion to RockWaste Matrix

7. Solid Waste Emplaced in a Matrix of Drilied Holes - No Melting

8. Solid Waste Emplacement in a Deep Hole In-Place Conversion to a Rock-Waste Matrix

9. Liquid Waste Emplaced in a Deep Hole - InPlace Drying and Conversion to a RockWaste Matrix

10. Liquid Waste Emplaced by Hydraulic Fracturing - In-Place Conversion to a Solid
Research and Development Totalcost Total Time Militions of Years Dollars

50

90

50

15

Total Time for 0peration, Years $(a)$

$15 \quad 20-25$

20

25

160

20

25

20

25

70

20

30

160

25

$30-35$

180

25

$30-35$

50

10

$15-20$

a. Includes Research and Development time 
which can be directly applied to them. Because Concept 2 involves investigation of in-place conversion to a solid and a more extensive demonstration plant than the mined cavity concepts without melting, the total Research and Development funding required is estimated to be on the order of $90 \mathrm{million}$ dollars. The remaining concepts require Research and Development funding of about three times the mined cavity nonmelting concept as a result of additional studies to establish procedures and techniques for disposing of liquid waste, allowing in-place conversion and/or drilling deep holes. The total time required to complete Research and Development studies for individual disposal concepts ranges from 10 to 25 years. Details of estimated time schedules for the Research and Development efforts associated with specific concepts are presented in Appendix G. Information concerning the scope of the Research and Development studies on a generalized basis for the geologic disposal concepts is presented in the following sections.

\subsubsection{Thermal and Radiation Effects}

Laboratory and field experimental work, and developmental work on a pilot-plant scale is believed to be required for each of the concepts to assure that geologic confinement of waste is not impaired by thermal and radiative effects. This is the basic approach being taken in the development studies of bedded salt as a host geologic environment, and as stated in Reference 123,"...extrapolation of...laboratory data to the gross effects of large quantities of waste on actual rock formations is diff $i-$ cult; construction and operation of an in-situ pilot facility to bridge the gap between laboratory and operations seem to be indicated." Key elements of studies to investigate thermal and radiation effects would include those discussed below:

Heat Dissipation. Thermal properties of the geologic environment (primarily thermal conductivity and heat capacity versus temperature) must be defined to the point where it can be assured that the long-term temperature transients resulting from emplaced waste will not exceed those desired for the waste or the canisters, the geologic formations, any nearby water-bearing formations and/ or the surface.

Repository stability. The effect of temperature and temperature transients on the horizontal and vertical stresses and rock properties must be defined. In addition to causing expansion and flow or slip, it is conceivable that temperature effects could cause phase or chemical changes in the surrounding rock. Heating of formations that contain bound water could result in special problems related to release of that water. Depending on formational plasticity, concepts involving direct placement of waste canisters in a geologic formation should have investigated the possibility of canister movement along with repository stability. Radiation could result in energy storage in the formation (by displacement of atoms or formation of defects within the crystalline lattice of the host rock) and later sudden release. 
The possibility of subsidence initiated by a release of this energy should also be investigated. Long term mechanics of host environments should be investigated for concepts which entail long-term access and operation.

Thermal/Radiation Decomposition. A variety of new chemical forms could be formed in-situ by either radiation or thermal decomposition. Again these decompositions are of special concern when bound water is present. The possibility of the formation of products corrosive to canisters and to liners, heat transfer equipment and connecting piping must be investigated. Also the possibility of formation of explosive and/or noxious products must be considered.

A variety of geological events could conceivably impair containment integrity under abnormal, catastrophic situations or perhaps under normal long-term occurrences. Such events would be the subject of Research and Development programs. An obvious geologic event to be considered is seismic activity. Any movement, folding, or faulting of the geologic environment must be considered. The possibility of exposure of waste by erosion and denudation and the possibility of leaching of waste by groundwater must be considered for al1 formations.

The extent of migration of radionuclides should be investigated. Potential transport mechanisms for these radionuclides include primarily, liquid and gas phase transport but also include solid state diffu- sion and migration along free surfaces. If bound water can be released, radionuclide mobility could be increased beyond that normally expected. The determination of formation permeability becomes important if bound water can be released and especially when considering concepts based upon emplacing liquid waste.

\subsubsection{In-Place Conversion}

A11 aspects of in-situ waste fixation must be analyzed and understood to permit accurate prediction of results. Four areas can be specifical1y noted: 1) heat and mass transfer; 2) rock-waste chemistry in the molten and high temperature solid phases; 3 ) system stability; and 4) the stress-force field. Heat and mass transfer models and studies must be developed to accurately predict behavior in all extremities of the affected geologic environment. Rock-waste chemistry must be studied under the temperature-pressure conditions to be encountered in a repository. The potential movement of the molten rock-waste mixture must be thoroughly defined. Rock mechanics studies must be performed to permit accurate prediction of forces, stresses, and rock physical reactions. Construction and operation of a pilot facility can be used to bridge the gap between laboratory studies and actual in-place conversion to a solid.

\subsubsection{Deep Hole Drilling}

Studies indicate that the formation of a deep hole is feasible with current technology in areas with low geothermal gradients. Unpredictable 
conditions at depths below those explored (about 9 kilometers) could stop an attempt at reaching full depth and/or desired diameter at full depth (see Section 4.0.5. Therefore, additional deep hole drilling development work is needed. Potential areas of investigation for conventional drilling techniques include developments in drilling and drilling mud technology to overcome the high temperatures at great depth, higher rotating table capacity, greater drill pipe strength, greater bit strength, higher casing strength and overcoming downhole stress conditions (temperature, pressure, rock mechanics). In addition, certain nonconventional drilling techniques may offer advantages for drilling of deep holes and should be investigated for deep hole concepts.

\subsubsection{Cost 0ptimization}

Although cost optimization is not necessarily critical for the sucessful application of a geologic disposal concept, it is important to assure cost-effective implementation of a concept.

Total tunnel volume required by Concept 1 to contain the United States waste inventory projected through the year 2000 could approach ten million cubic meters. Because of the total cost involved, advances that can be used to reduce tunnel volume requirements only a few percent can save millions of dollars. For example, the development of machines that can form burial holes and emplace waste from a minimum of working space could significantly reduce tunnel volume requirements and costs. Slight changes in the temperature limits associated with emplaced waste, the host geologic formation, any nearby water-bearing formations, and/or the surface could result in significant changes in excavation requirements. The above investigation of thermal properties can lead to sound temperature limits and the ability to optimize waste form and cavity dimensions to meet these limits.

For the matrix of drilled holes assuming 3000 meters of overburden and a 1500-meter thick host formation, over $1000 \mathrm{kilometers} \mathrm{of}$ drilled hole length would be required for the waste inventory projected through the year 2000 . Advances that can be used to reduce drilling costs could save great sums of money.

Optimization of waste form from a physical (ease of burial) as well as thermal standpoint should also be considered as a means for reducing drilling and mining requirements. Finally, continued investigation of drilling alternatives (see Section 4.0.5) that appear to be economically competitive with conventional mining/drilling methods is obviously warranted.

\subsubsection{Fluid Cooling Systems and Containment structures \\ Containment structures enhance} the retrievability of the waste while interim fluid cooling minimizes the area requirements for storage disposal.

Laboratory corrosion studies are needed to obtain corrosion rates for 
the important materials of construction when exposed to the environment of the disposal facility. Consequentry,the chemical and physical environment in the cavities and shafts of an actual pilot facility should be characterized so that realistic laboratory corrosion tests can be carried out. The most definitive information will be obtained from actual observations made in a pilot facility during its useful life time. Other potential areas of Research and Development may be associated with techniques to monitor and evaluate the integrity of containment structures such as repository 1 iners in addition to connection(s) between the repository and the surface facilities.

\subsubsection{Special Studies for Hydraulic Fracturing}

To develop a suitable mix formulation for hydraulic fracturing injection into a geologic formation, specifications for the mix are needed including characteristics and durability of the final waste-grout solid, viscosity, thickening time, setting time, compressive strength, phase separation and fluid loss. Pumpable mixes (slurries) whose viscosity remains low and consistency remains stable during injection need to be developed. Retention of radionuclides by the final solid must be evaluated and studies must be undertaken to develop solids with improved characteristics. Several materials such as cements, clays, etc., should be evaluated. Also, further work is needed to develop laboratory test procedures that will more closely simulate the mixing and pumping operations in the fracturing plant.

The measurement of surface up$1 \mathrm{ifts}$ is needed to indicate if a vertical fracture has occurred when emplacing waste by hydraulic fracturing. Improved techniques are needed to determine reliably the beneficial extent of waste-grout sheets. Theoretical derivation of surface uplift should be compared to experimental data to develop a workable model for determining how to prevent vertical fractures.

\subsubsection{Pilot-Scale Demonstration}

A pilot-scale demonstration to extend information obtained in laboratory studies relative to certain key items is expected to be required for the geologic concepts. The pilot-scale demonstration is expected to require at 1 east 10 years of design, construction, and actual operation for most of the concepts. The deep-drilled hole concepts are believed to require at 1 east 20 years for demonstration because of problems anticipated in routine driling to great depth. The major purpose of the demonstration is to supplement and confirm the results of 1 aboratory investigations on thermal, chemical, mechanical, and radiation damage resistance properties of the geologic environment. Confirmation that handling and disposal of waste can be accomplished safely and that acceptable drilling and excavation techniques exist will also be done here. 
4.6.8 Other Research and Development Needs

The development of materials and techniques for the final sealing of openings that were once used for repository operation is needed.

To maintain the integrity of a geologic formation potentially suitable for disposal of radioactive waste, development of techniques other than core boring to assure that the formation is not penetrated by cracks or faults that could conceivably connect the cavity or tunnels to surrounding water bearing formations might be warranted.

Continued development of techniques to monitor tunnel movement would be desirable; such movement could signal the onset of formational cracking.

\subsection{TIME REQUIREMENTS FOR COMMERCIAL OPERATION}

Estimates of the total time required to place disposal facilities for each of the geologic concepts in operation are shown in Table 4.38. Total time requirements range from 15 years to 35 years, depending upon the concept under consideration, with the time necessary to complete needed Research and Development work being the controlling factor in the time required to implement the concepts. Beyond Research and Development studies, other activities needed to implement a disposal concept are design, licensing, and construction of the repository. These elements are estimated to require 5 to 10 years beyond that for research and development. Estimated time require- ments of the key elements for each of the geologic concepts are presented in Figures 4.G.1 through 4.G.10 contained in Appendix 4.G. The objective of the site evaluation is to examine alternative sites on a national scale and select specific sites (formations) for further detailed evaluation.

When candidate sites have been identified, site evaluation studies will confirm that the potential sites selected have the characteristics and properties that will permit long-term isolation of radioactivity from man's environment. The specific geology and rock mechanics of the host rock formation and the geology and hydrology of the related nearby geologic environment will be defined in detail and evaluated.

For each of the concepts, a 5 to 8 year effort is estimated to be involved for site evaluation activities.

It is believed that, in general, a total of about 10 years will be required for licensing, designing and constructing the commercial facility. Five years are estimated to be required to obtain a construction permit and 5 years are allotted for completion of design and construction, portions of which are conducted concurrently.

4.8 CAPITAL AND OPERATING COSTS Preliminary capital and operating costs and levelized total system disposal costs (those charged at the time of reprocessing to cover waste management costs) were derived for each of the concepts and are presented in Table 4.39. All of the necessary 


\begin{tabular}{|c|c|c|c|c|c|c|}
\hline \multicolumn{2}{|r|}{ Concept } & \multicolumn{2}{|c|}{$\begin{array}{l}\text { Capital and 0p } \\
\text { Disposal Conce } \\
\text { Reference Plant Cost(b) } \\
\text { (million dollars) }\end{array}$} & \multicolumn{2}{|c|}{$\begin{array}{l}\text { Total Waste Management } \\
\text { Unit Charges(a) } \\
\text { S/MI Milis/kw-hr }\end{array}$} & $\begin{array}{r}\text { Geologic } \\
\text { comments } \\
\end{array}$ \\
\hline 1 & $\begin{array}{l}\text { Solid waste Emplaced in Mined Cavity - } \\
\text { No Fluid Cooling or Meiting }\end{array}$ & 230 & $\cdot 2.8$ & 12,000 & 0.046 & $\begin{array}{l}\text { Almost } 70 \% \text { of the capital costs } \\
\text { attributed to tunneling. Operating } \\
\text { costs based on staff of } 34 \text {. (c) }\end{array}$ \\
\hline & $\begin{array}{l}\text { Solid Waste Emplaced in Mined Cavities } \\
\text { Interim Liquid Cooling and Conversion } \\
\text { to Rock-Waste Matrix }\end{array}$ & - & 1.4 & 9,000 & 0.034 & $\begin{array}{l}\text { Of the capital cost, hole drilling } \\
\text { requires about } 22 \% \text {, the cavity } \\
\text { liner about } 30 \% \text {, and all other } \\
\text { equipment and facilities about } 48 \% \text {. } \\
\text { operating costs based on staff of } 34 \text {. }\end{array}$ \\
\hline 3 & $\begin{array}{l}\text { Solid Waste Emplaced In Manmade Struc- } \\
\text { tures in Geologic Formations - } \\
\text { Interim Air Cooling }\end{array}$ & 550 & 4 & 17,000 & 0.064 & $\begin{array}{l}\text { About } 75 \% \text { of the capital costs due } \\
\text { to drilling of ventijation and access } \\
\text { holes. Operating costs based on } \\
\text { staff of } 47 \text {. }\end{array}$ \\
\hline 4 & $\begin{array}{l}\text { Solid Waste Emplaced in Manmade Struc- } \\
\text { tures in Geologic Formations - Interim } \\
\text { water Cooling }\end{array}$ & 240 & 3.6 & 12,000 & 0.047 & $\begin{array}{l}\text { Major capital cost items are excava- } \\
\text { tion } 38 \% \text {, pressure vessel } 23 \% \text {, rate } \\
\text { sensitive anchors } 8 \% \text {, and containment } \\
\text { she } 114 \% \text {. Operating costs based on } \\
\text { staff of } 47 \text {. }\end{array}$ \\
\hline 5 & $\begin{array}{l}\text { Liquid waste Emplaced in a Mined } \\
\text { Cavity - In-place Drying and Con- } \\
\text { version to Rock-Waste Matrix }\end{array}$ & 22 & 1.4 & 6,400 & 0.024 & $\begin{array}{l}\text { About } 30 \% \text { of capital costs due to } \\
\text { dritiling and excavating, and } 65 \% \text { to } \\
\text { steam condensers. Operating costs } \\
\text { based on staff of } 19 \text {. }\end{array}$ \\
\hline 6 & $\begin{array}{l}\text { Liquid waste Emplaced in Exploded } \\
\text { Cavities - In-Place Drying and Canver- } \\
\text { sion to Rock-waste Matrix }\end{array}$ & 23 & 1.4 & 6,300 & 0.024 & $\begin{array}{l}\text { About } 25 \% \text { of capital costs due to } \\
\text { drilling and excavating, and } 60 \% \text { to } \\
\text { steam condensers. Operating costs } \\
\text { based on staff of } 19 \text {. }\end{array}$ \\
\hline 7 & $\begin{array}{l}\text { Solid Waste Emplaced in a Matrix of } \\
\text { Drilled Holes - No Melting }\end{array}$ & 140 & 1.5 & 10,000 & 0.039 & $\begin{array}{l}\text { About 95\% of capital costs due to } \\
\text { driliting holes. Operating costs } \\
\text { based on staff of } 34 \text {. }\end{array}$ \\
\hline 8 & $\begin{array}{l}\text { Solid Waste Emplaced in a Deep Hole. } \\
\text { In-place Conversion to a Rock-Waste } \\
\text { Matrix }\end{array}$ & 160 & 1.6 & 11,000 & 0.041 & $\begin{array}{l}\text { About } 95 \% \text { of capitai costs due to } \\
\text { drilling holes. Operating costs } \\
\text { based on staff of } 36 \text {. }\end{array}$ \\
\hline 9 & $\begin{array}{l}\text { Liquid Waste Emplaced in a Deep Hole- } \\
\text { In-Place Orying and Conversion to } \\
\text { Rock-Waste Matrix }\end{array}$ & 80 & 7.1 & 8,000 & 0.030 & $\begin{array}{l}\text { About } 95 \% \text { of capital costs due to } \\
\text { driling holes. Operating costs } \\
\text { based on staff of } 19 \text {. }\end{array}$ \\
\hline$: 0$ & $\begin{array}{l}\text { Liquid Waste Emplaced by Hydraulic } \\
\text { Fracturing - In-Place Conversion to } \\
\text { a solid }\end{array}$ & 15 & 1.0 & 11,000 & 0.042 & $\begin{array}{l}\text { About } 20 \% \text { capital costs due to } \\
\text { drilling wells. Operating costs } \\
\text { based on staff of } 19 \text {. }\end{array}$ \\
\hline $\begin{array}{l}\text { a. } \\
\text { b. } \\
\text { c. }\end{array}$ & $\begin{array}{l}\text { Assessed at time of reprocessing. } \\
\text { Based upon managing waste from a plan } \\
\text { fuel for an assumed } 25-y e a r \text { plant lif } \\
\text { Size of staff based upon operating a }\end{array}$ & $\begin{array}{l}\text { nt which re } \\
\text { fe. } \\
\text { single ref. }\end{array}$ & $\begin{array}{l}\text { rocesses } 5 \text { met } \\
\text { erence reposito }\end{array}$ & $\begin{array}{l}\text { ic tons/day } \\
y \text {. }\end{array}$ & $(1825 \mathrm{MT} / \mathrm{yr})$ of & spent nuclear \\
\hline
\end{tabular}

components of a complete waste management system are included in the total system disposal costs. The system cost includes, for example, any added spent fuel transport for cases where the fuel reprocessing plant and the disposal site must be the same location, interim liquid waste storage, waste solidification, interim solid waste storage, transport of solid waste canisters to the disposal site, and final disposal. The disposal costs do not include the Research and Development studies costs devel- oped in section 4.6. Volume 1 , Section 3 of this study contains a detailed discussion of the procedures used to develop the levelized cost information and presents costs associated with variations in the type of rock used for a disposal site and in the depth at which the repository is located.

For each concept, disposal system costs were developed for a reference facility sized to handle the highlevel waste from a 5 metric ton/day (1825 MT/yr) LWR fuel reprocessing 
plant. Costs for this reference facility were then scaled as described in Volume 1 , Section 3 , to accommodate the total requirements for a 25-year period starting in 1980

The highest total disposal cost corresponds to a value of $\$ 17,000$ per metric ton of fuel. This cost is equivalent to about 0.064 mills per kilowatt-hour of electricity, or less than 1 percent of current nuclear electric power generating costs. Consequently, none of the geologic disposal concepts would significantly increase the cost of nuclear electric power, and thus cost will probably not be of great initial importance when ranking the various geologic concepts.

Appendix 4.F presents the reference bases used for estimating the systems costs.

\subsection{PUBLIC RESPONSE}

This section discusses some considerations of public response to various characteristics of geologic concepts for disposal of radioactive waste. It should be noted that public reaction to a certain characteristic will not always be uniform. For example, public reaction to the fact that the waste is isolated from man's environment by hundreds of meters of "rock" can be favorable. On the other hand, there will be those who question the concept simply because the isolation is required in the first place or, more importantly, because the isolation could conceivably make the waste irretrievable, especially in case of a major geo- logic event. It should also be noted that it may be possible to counter certain negative or unfavorable reactions with information and educational programs once details are available concerning a specific site. This expectation is borne out to some extent by the results of a preliminary pilot survey test conducted with a small sample of people, as described in volume 1, Section 3 of this study. The test described in Section 3 discusses in detail the respondents' perception of waste management factors and characteristics of a number of geologic types of waste management systems.

In addition to isolation of the waste by geologic distance, public acceptance could be enhanced by the possibility of locating the repository far from population centers. However, in the pilot test referred to above, the "average" respondent felt that distance from our immediate environment and nearby population density were two relatively unimportant criteria for waste management. The fact that geologic emplacement will isolate the waste from surface storms and accidents and reduce the possibility for sabotage and other malicious acts of man appear to be perceived as important characteristics.

Unfavorable public reaction could arise from the fact that surface transportation of waste canisters will probably be involved in concepts based on emplacement of solid waste. Assurance of the suitability of geologic disposal is based in part on seismic and tectonic stability, and 
demonstrated past stability may be questioned as an adequate indicator of the future. Finally, geologic isolation leads to difficulties in monitoring of the system and the detection of releases of radioactivity, if any. In the above referenced test results, the subjects ranked protective reaction (countermeasures in the event of release of radioactivity), retrievability, emplacement operations (including surface transportation), and long-term stability as important risk characteristics for geologic concepts.

\subsection{POLICY CONSIDERATIONS}

An examination of written national and international policies that might apply to the disposal of high-level nuclear waste was presented in Volume 1, Section 3 .

Those solid waste disposal concepts which do not involve melting are compatible with existing policies and programs. Specifically, they could fulfill the requirements of a Federal Repository (facility for permanent custody) discussed in 10 CFR Part 50, Appendix F. (167) In addition they are compatible with the current plans for a Federal Retrievable Surface Storage Facility(168) for interim storage of solidified waste prior to ultimate disposal.

The national rules and regulations as established by the Atomic Energy Commission in 10 CFR 50 (Appendix F) state specifically that all highlevel nuclear waste must be disposed of in solid form on federally owned and controlled land. This clearly affects the liquid waste disposal concepts and those concepts which permit waste-rock melting. If the facility for permanent custody were based on liquid emplacement and/or melting, the existing AEC rules and regulations would be in conflict. In addition, liquid emplacement and melting are not compatible with the current plans for a retrievable storage facility. (168)

Internationally, the Nonproliferation Treaty could conceivably affect all of the concepts since it provides for the safeguarding of all source and special fissionable materials. The treaty specifies that the International Atomic Energy Agency safeguard standards must be observed in all peaceful nuclear activities whether within a state or under its control anywhere.

\subsection{ENV IRONMENTAL IMPACT}

The nonradiological environmental impact of geologic concepts were presented in Volume 1, Section 3 of this study, and are reviewed briefly here. Major environmental impacts resulting from geologic disposal concepts are expected to be the commitment of land, the transportations needs, the associated potential loss of resources, and the potential effects of heat dissipation.

For the total U.S. waste inventories projected to need disposal through the year 2000 , there is the commitment of typically 130 square kilometers (50 square miles) of 1 and, including a 3.2 kilometer buffer zone surrounding the disposal area. Larger areas must in general be committed for the liquid disposal concepts, up to 1600 square kilometers 
for Concept 10, because a multiplicity of sites is necessary to allow locating the reprocessing plant at the disposal area. Assuming a 10-year holdup time at the reprocessing plant, up to 200 megawatts of thermal power might be dissipated to the surrounding formation for eventual transfer to the atmosphere. Up to 600 megawatts might be dissipated without the holdup period as would be the case for concepts utilizing liquid waste emplacement. This amount of heat is less than $30 \%$ of that rejected from one 1000 MWe thermal electrical generating plant. Although it is conceivable that the biological environment could be affected by this chronic heat source, (176) no major consequences are expected, but detailed analyses of specific sites will be required.

As much as ten million cubic meters of mine tailings might result from excavation operations associated with mined cavity concepts which do not involve waste-rock melting.

Esthetic impact can be minimized by the onsite "environmental" treatment of mine tailings. If salt and perhaps other evaporites are removed from the repository, ocean disposal or disposal in nearby abandoned mines may be required for the tailings. During the mining operation and disposal of mine waste, some dust contamination of the air could also be expected.

Nominal demographic impact and water and electrical consumption are expected. Finally, for concepts employing disposal of solid waste, there will be the impact of rail or truck shipments. For the waste to be disposed of in the year 2000, the annual shipping rate of canisters could exceed 3000. Assuming each shipment contains six canisters, over 500 trips into and out of the complex could be expected. 


\section{REFERENCES}

1. E. B. Ekren et al., Geologic and Hydrologic Considerations for Various Concepts of $\mathrm{High}-$ Leve1 Radioactive Waste Disposal in Conterminous United States, USGS-2198-1, Dept. Of the Interior Geological Survey, Federal Center, Denver, Co, 1974.

2. E. C. Robertson, "The Interior of the Earth--An Elementary Description," U.S. Geol. Survey Circ. 532, p. $10, \frac{1966 .}{1966}$

3. T. Atwater, "Implications of Piate Tectonics for the Cenozoic Tectonic Evolution of Western North America," Geol. Soc. America Bu11., vol. 81, no. 12, pp. 3513-3536, 1970.

4. B. A. Bo1t, "Seismicity," in vo 1. 1: Proc. Int. Conf. on Microzonation for Safer Construction, Research, and Application, Seattle, WA, pp. 13-28, Oct. 30 - Nov. 3., 1972 .

5. J. Gilluly, "Crustal Deformation in the Western United States," in Johnson, Helgi, and B. L. Smith, ed., The Megatectonics of Continents and Oceans, Rutgers Univ. Press, Newark, NJ, pp. 47-73, 1970.

6. E. A. Silver, "Late Cenozoic Underthrusting of the Continental Margin of Northernmost California," Science, vol. 166, pp. 1265-1266, 1969 .

7. E. A. Silver, Structure of the Continental Margin Off Northern California North of the Gorda Escarpment, Ph.D. thesis, Univ. of California, San Diego, La Jolla, CA, p. 123, 1969.

8. E. A. Silver, "Small Plate Tectonics in the Northeastern Pacific," Geol. Soc. America Bu11., vo1. 82, pp.3497-3496, 1971.

9. C. F. Park, Jr. and

R. A. MacDiarmid, Ore Deposits, San Francisco, W. H. Freeman and Company, p. 475, 1964.
10. National Academy of Sciences, National Research Council, Disposal of Radioactive Wastes in Bedded Salt Deposits, Report by the Committee on Radioactive Waste Management, Washington, $D C$, U.S. Government Printing office, 1970 .

11. W. J. Boegly, Jr., F. L. Parker, and E. G. Struxness, Disposal of Radioactive Wastes in Geologic Formations, ORNL-P-2537, U.S. Atomic Energy Comm., Oak Ridge National Laboratory, p. 24 , Available from NTIS, Springfield, VA 22151 , 1966.

12. R. L. Bradshaw, T. F. Lomenick, W. C. McClain, and F. M. Empson, "Model and Underground Studies of the Influence of Stress, Temperature, and Radiation on Flow and Stability in Rock Salt Mines," Proc. 1st Int. Soc. Rock Mechanics Cong., 1966, Lisbon, Portugal, Laboratorio Nacional Engenharia Civil, vol. 2, pp. 429-433, 1966.

13. J. D. Bredehoeft, C. R. B lyth, W. A. White, and G. B. Maxey, "Possible Mechanism for Concentration of Brines in Subsurface Formations," Am. Assoc. Petroleum Geologists BuIT.' vol. 47, no. 2, pp. 257-269, 1963.

14. A. Clebsch, Jr. and E. H. Baltz, "Progress in the United States of America Toward Deep-Well Disposal of Liquid and Gaseous Radioactive Wastes," in Disposal of Radioactive Wastes into the Ground-Symposium, Proc. Int. Atomic Energy Agency, Vienna, 1967 , pp. 591-604, 1967 .

15. L. F. Dellwig, "Flowage of Rock Salt at Lyons, Kansas," Kansas State Geol. Survey Bu11., no. 130, pt. 4, pp. $i 66-175,1958$.

16. J. C. Frye, Chm., Disposal of Solid Radioactive Wastes in Bedded Salt Deposits, Natl . Acad. Sci., Comm. Radioactive Waste Management, Nat 7 Research Counci1, p. 28, 1970. 
17. J. E. Galley, Chm., Committee on Geologic Aspects of Radioactive Waste Disposal, "Report to the Division of Reactor Development and Technology," U.S. Atomic Energy Commission: Natl. Acad. Sci.--Natl. Research Council, Div. Earth Sci., May 1966 .

18. F. Gera, "Review of Salt Tectonics in Relation to the Disposal of Radioactive Wastes in Salt Formations," Geol. Soc. America Bull., vol. 83, no. T2, pp. 3557-3574, 1972 .

19. J. D. Love, and L. Hoover, A Summary of the Geology of Sedimentary Basins of the United States, with Reference to the Disposal of Radioactives Wastes, U.S. Geol. Survey TEI 768, $196 \overline{1}$.

20. K. V. Mysanikov, "Creating Underground Storage Cavities with Contained Nuclear Explosions Detonated in Rock Salt," in French and Soviet papers presented at Second Panel on the Peaceful Uses of Nuclear Explosions, 18-22 January 1971, Vienna, Lawrence Livermore Laboratory UCRL Trans. 10543 , pp. 70-80, 1971 .

21. W. G. Pierce, and E. I. Rich, Summary of Rock Sa it Deposits in the United States as Possible Storage sites for Radioactive Waste Materials, U.S. Geol. Survey Bu11.1148, p. 91, 1962.

22. T. D. Reynolds, and E. F. Gloyna, Reactor Fuel Waste Disposal Project--Permeability of Rock Salt and Creep of Underground Salt Cavities-Final Report, U.S. Atomic Energy Comm. Div. Tech. Inf. TID-12383, p. 121, 1960 .

23. W. L. Stokes and D. J. Varnes, "Glossary of Selected Geologic Terms, with Special Reference to Their Use in Engineering," Proc. Colorado Sci. Soc.,

vol. 16, P. 165, 1955.

24. W. J. Drescher, "Hydrology of Deep-wel1 Disposal of Radioactive Liquid Wastes," in Fluids In Subsurface Environments--A Symposium, Am. Assoc. Petrole um Geologists Mem. 4, Pp. 399-406, 1965 .
25. J. J. Geraghty, D. W. Miller, F. VanDerheeden, F. L. Teoise, Water Atlas of the United States, Water Information Center, Inc., Port Washington, NY, 1973.

26. S. W. Lohman et a 1., Definitions of Selected Groundwater Terms-Revisions and Conceptual Refinements, U.S. GeoT. Survey WaterSupply Paper 1988, p. 21, 1972 .

27. G. A. Dinwiddie, U.S. Geol. Survey, 1973.

28. K. Terzaghi and R. B. Peck, Soil Mechanics in Engineering Practice, John Wiley and Sons, Inc., New York, NY, p. $566,1960$.

29. T. D. Secor, Jr., "Role of Fluid Pressure in Jointing," Am. Jour. Sci., vol. 263, no. 8, pp. 633-646, 1965 .

30. P. R. Fenske, "Prediction of Radionuclide Migration in Ground Water," Chap. 7, Technical Discussions of off $\overline{\text { site }}$ Safety Programs for Underground Nuclear Detonations, U.S. Atomic Energy Comm. NVO-40 (Rev. 2 ), pp. 69-82, 1969 .

31. S. T. Algermissen, "Seismic Risk Studies in the United States," Proc. 4th World Conf. Earthquake Eng., Asociacion Chilena de Sismologia e Ingeneria Antisismica, Santiago, chiTe, voT. T, pp. 14-27, 1969.

32. 0. E. Meinzer, The Occurrence of Ground Water in the United States, With a Discussion of Principles, U.S. Geo1. Survey Water-Supply Paper 489 , p. 321 , 1923.

33. W. C. WaTton, Groundwater Resource Evaluation, McGraw-Hi 11 Book Co., New York, NY, P. 664, 1970 .

34. T. Arnow, Ground-Water Geology of Bexar County, Texas, U.S. GeoT. Survey Water-Supply Paper 1588, 1963. 
35. R. E. King et al., "Resume of the Geology of the South Permian Basin, Texas and New Mexico," Geol. Soc. America Bull. vol. 53, no. 4, pp. 539-560, 1942 .

36. J. C. Denton, ed., Geothermal Energy, Final Repor of the Geothermai Resources Research Conference, Battelle Seattle Research Center, Seattle, WA, September 18-20, 1972, Univ. of Alaska, College, AK, p. 95, 1972 .

37. C. L. McGuinness, The Role of Ground Water in the National Water Situation, U.S. Geo1. Survey Water-SuppTy Paper 1800, p. 1121,1963 .

38. G. A. Waring, Therma 1-Springs of the United States and other countries of the WorTd--A Summary, Revised by R. R. Blankenship and Ray Benta11, U.S. Geol. Survey Prof. Paper 492, p. 383, 1965.

39. E. A. Merewether, J. A. Sharps, J. R. Gill, and M. E. Cooley, Shale, Mudstone, and Claystone as potential host Rocks for the Underground Emplacement of Waste, U.S. Geol. Survey Open-File Report, 1973.

40. I. W. Marine, "The Permeability of Fractured Crystalline Rock at the Savannah River Plant Near Aiken, South Carolina," Geological Survey Research, Chap. B, U.S. Geol. Survey Prof. Paper, $575-B$, p. B 203-B-211, 1967 .

41. D. J. Cederstrom, Evaluation of Yields of Wells in Consolidated Rocks, Virginia to Maine, U.S. Geol. Survey Water-SuppTy Paper 2021, p. 38, 1972.

42. D. F. Hewett, and G. W. Crickmay, The Warm Springs of Georgia, Their Geologic Relations and origin; a Summary Report, U.S. Ge01. Survey Water-Supply Paper 819 , p. 40,1937 .

43. D. B. Grove, A Method to Describe the Flow of Radioactive Ions in Ground Water-Final Report, Sandia Laboratories, SC-CR-70-6139, December 1, 1966 through June $30,1968$.
44. H. G. F. Winkler, Die Genese der Metamorphen Geistine, S. T-2T8, Springer, Berlin-Heidel berg-New York, 1965, 2. Auf1. 1967.

45. D. S. Korzhinsky, outline of Metasomatic Processes, 2nd Ed. Moskwa. Akad. Nauk. U.S.S.R. 1955 .

46. E. Roedder, "Fluid Inclusions as Samples of Ore Fluids," Geochemistry of Hydrothermal ore Deposits, Holt, Rinehart and Winston, New York, NY, 515-574, 1967.

47. 0. Braitsch, Entstehung and Stoffbestand der SaTzTagerstatten, Springer, BerTinGöttingen-Heidelberg, 1962.

48. D. E. White, "Saline Waters of Sedimentary Rocks," Symposium on Fluids in Subsurface Environments, Mem. Am. Assoc, Petrol.

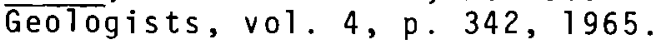

49. C. B. Hunt, P. Averitt and R. L. Miller, Geology and Geography of the Henry Mountains Region, Utah, U.S. Geol. Survey Prof. Paper 228, p. 234, 1953.

50. R. J. Foster, General Geology, Charles E. Merrill Pub. Co., Columbus, $\mathrm{OH}$, p. 630,1969 .

51. S. A. Schumm, The Disparity Between Present Rates of Denudation and Orogeny, U.S. Geol. Sur vey Prof. Paper $454-\mathrm{H}$, pp. HT-H13, 1963.

52. M. A. Melton, "The Geomorphic and Paleoclimatic Significance of Alluvial Deposits in Southern Arizona," Jour. Geology, vol. 73, no. 1, pp. T-38, T965.

53. J. Gilluiy, "Plate Tectonics and Magmatic Evolutions," Geol. Soc. America Bu11., vol. 82, no. 9, pp. 2383-2396, 1971.

54. C. F. Richter, Elementary Seismology, San Francisco, CA, W. H. Freeman and Co., p. 768, 1958 .

55. J. L. Coffman and

C. A. von Hake, United States Earthquakes, 1970 , U.S. Dept. Commerce, Nat7. Oceanic and Atmospheric Adm., Silver Springs, MD, P. 81, 1972 . 
56. 0.W. Nutt1i, "Magnitude, Intensity and Ground Motion Relations for Earthquakes in the Central United States," in vol. 1: Proc. Internat. Conf. on Microzonation for Safer Construction, Research, and Application, oct. 30 -Nov. 3 , Seattle, WA, T972.

57. I. Zietz and E. Zen, "Northern Appalachians," Geotimes, vol. 18, no. 2, pp. $24-28,1973$.

58. P. B. King, "Tectonic Features," U.S. Geol. Survey Map, sheet no. 70, scale 1:7,500,000, 1967.

59. Proc. Int. Conf. on Microzonation for Safer Construction, Research, and Application oct. 30 - Nov. 3, Seattle, WA, voT. T, pp. T-435, vol. 2, pp. 439-987, 1972 .

60. H. C. Rodean, Nuclear-exp10sion Seismology, U.S. Atomic Energy Comm. TID -25572 , p. 156 , Available from NTIS, U.S. Dept. Comm., Springfield, VA 22151 , 1971.

61. G. J. Kukla and R. K. Matthews, "When Will the Present Interglacial End?" Science, vol. 178, no. 4057, pp. T90-T9T, 1972 .

62. R. F, Flint, Glacial and Quaternary Geology, John wiley and Sons, New York, NY, p. 892 , 1971 .

63. R. F. Flint et al., "Glacial Map of North America, 2 sheets, Pt. 1," "Bibliography and Explanatory Notes, Pt. 2," Geol. Soc. America Spec. paper 60, p. 37, 1945.

64. R. W. Fairbridge, "Eustatic Changes in Sea Level," in vol. 4, Physics and Chemistry of the Earth, Pergamon Press, New York, NY pp. $99-185,1961$.

65. H. Nakagawa, "Quaternary Sea Leve is of the Japanese Is lands," in Sea Level Changes and Crustal Movements of the Pacific, 11th Pacific Sci.Cong., T966, Tokyo, Symposium 19, Osaka City Univ., Jour. Geosciences, vol. 10, art. 1-5, pp. 37-42, T967.
66. M. I. Budyko, "The Future $C 1 j-$ mate," EOS, Am. Geophys. Union Trans., vol. 53, no. 10, pp. 868-874, 1972 .

67. I. J. Winograd, "Near Surface Storage of Solidified High-Level Radioactive Wastes in Thick $(400-2,000$ foot) Unsaturated Zones in the Southwest," (abs.): Geol. Soc. America Abs. with Programs, vol. 4, no. 7, pp. 708-709, 1972 .

68. J. J. Cohen, A. E. Lewis, and R. L. Braun, Use of a Deep Nuclear Chimney for the In-situ Incorporation of Nuclear FuelReprocessing Waste in Molten Silicate Rock, Lawrence Radiation Lab., Report to USAEC, UCRL-51044, May 1971.

69. L. M. Gard, Jr., Geologic Studies, Project Gnome, Eddy County, New Mexico, U.S. Geol. Survey Prof.Paper 589, p. 33, 1968.

70. 0.F. Tuttle and N. L. Bowen, "Origin of Granite in the Light of Experimental Studies in the System NaAlSi ${ }_{3} \mathrm{O}_{8} \mathrm{KAISi} \mathrm{O}_{8}-\mathrm{SiO}_{2}-$ $\mathrm{H}_{2} \mathrm{O}$," Geol. Soc. American Mem. vol. 74, p. 153,1958 .

71. T. H. McCulloh, Mass Properties of Sedimentary Rocks and Gravimetric Effects of Petroleum and Natura T Gas Reservoirs, U.S. Geol. Survey Prof. Paper 528-A, pp. A1-A50, 1967.

72. R. K. Blankennagel and J. E. Weir, Jr., Geohydrology of the Eastern Part of Pahute Mesa, Nevada Test Site, Nye County, NV, U. S. Geological Survey Prof. Paper 712-B, 1973.

73. L. T. Grose, "Geothermal Energy: Geology, Exploration, and Developments, Pt. 1," Colorado School Mines, Mineral Industries Bull., vol. 14, no. 6, p. 14, 1971.

74. "New Deepest Producer, Area Records Reported," World 0 il,

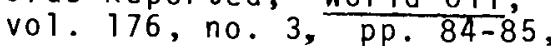
Feb. 15,1973 . 
75. L. H. Godwin et a1., "Classification of Public Lands Valuable for Geothermal Steam and Associated Geothermal Resources," U.S. Geol. Survey Circ., 647, p. 18 , 1971 .

76. W. A. Nevi11, General Chemistry, McGraw-Hill Book Company, NY, p. $146,1967$.

77. R. C. Routson, A Review of Studies on Soil-Waste Relationships on The Hanford Reservation from 1944 to 1967, BNWL-1464, March 1973 .

78. Fenix and Scisson, Inc., Deep Hole Drilling Feasibility Study, Study Report prepared for the AdVanced Research Projects Agency for the USAEC, May 1969.

79. G. C. Mathis, Study of Drilling and Mining Technology Related to Radioactive Waste DisposaT, Consultant Report, Fenix and

Scisson, Inc., February 1973.

80. J. Scott, "Deep Drilling Zooms to 506 Holes," Petroleum Engineer, pp. 45-52, March 1973.

81. R. C. McCurdy, Impact of New Technology on the Petroleum Industry $=1946$ to 1965 , National Petroleum Counci1, 1967 .

82. "29,000 Foot Target Depth Set for 0klahoma Wildcat," World 0il, pp. 56-57, February $197 \overline{3}$.

83. W. C. Maurer, "New Drilling Methods Move Close to Field," The 0 il and Gas Journal, pp: 7 $\overline{4-79}$, February 26,1968 .

84. W. C. Maurer, "Thermal Spalling, Chemical Drills," The 0il and

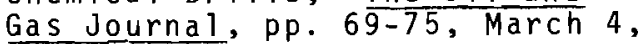
1968.

85. W. C. Maurer, "Novel Mechanical Drilis Show Promise," The 0il and Gas Journal, pp. $91-98$, March 11, 1968.

86. W. C. Maurer, Naval Drilling Techniques, Pergamon Press, New York, NY, 1968.

87. W. Bascom, A Hole in the Bottom of the Sea, DoubTeday and Company, Inc., 1961.
88. "The First Practical Application of the Subterrene," The Atom, vol. 10, no. 4, May $\overline{973 .}$

89. W. M. Adams, "Nuclear Reactor Apparatus for Earth Penetration," U.S. Patent \#3155194, 1965.

90. Drilling Research Inc., Annual Reports, Houston, TX, 1959-63.

91. R. E. Bouche, Drilling Rocks with Plasma Jets, MS thesis T-992, Colorado School of Mines, 1964 .

92. R. Bakish, Introduction to Electron Beam Technology, Wiley

\& Sons, New York, NY, 1962.

93. R. A. Gladstone and A. Kettaneh, news release regarding use of lasers to thermally degrade rock, Office of Public Relations, Massachusetts Institute of Technology, Cambridge, MA, November 24 , 1966.

94. I. H. Rubow, "Jet Piercing in Taconite," Mines Magazine, Colorado School of Mines, March 1956.

95. V. S. Kravchenko, A. P. Obvastov and V. V. Ustinov, "Dustless Breaking of Rocks Electrically," Min. Congr. Journal, pp. 53-55, May 1961.

96. "Methods of an Apparatus for Splitting Nonmetallic Brittle Materials," English Patent

No. $1019737,1966$.

97. E. Sarapuu, "Electrical Disintegration Drilling," Rock Mechanics, Pergamon Press, New York, NY, pp. $173-184,1963$.

98. J. Steude1, "Versuche Mit Mikrowellen Zur Zerstorung Von Sansteinen," Gluckauf-Forschungshefte, pp. 117-125, Apri1 1965.

99. N. P. Ostrovskij, "Deep-Hole Driliing with Explosives," Gostoptekhia 'dat Moscow, Translation by Consultants Bureau Enterprises, Inc., New York, NY, 1960.

100. G. E. Cannon, "Development of a High-Speed, Low-Torque Drilling Device," presented at AIME meeting, Dallas, TX, October 6-9, 1957. 
101. J. E. Ecke1, F. H. Deily and k. W. Ledgerwood, "Development and Testing of Jet Pump Pellet Impact Drill Bits," Trans. AIME no. 207, pp. 1-9, 1956 .

102. R. J. Howe, Esso Production Research Co., Houston, TX, personal communications, 1963.

103. A. P. Sviridov, "Semiautomatic Ultrasonic Device," Izvestiya Vysshikh Uchebnykh Zavedenii: Priborostroenie U.S.S.R., no. 2 , p. 159, 1958 .

104. L. A. Yutkin, "Electrohydraulic Effect," Mashgiz (State Scien$t$ ific Technical Press for Machine Construction Literature) Moscow, 1955, Translation no. AD267-722, Armed Services Technical Information Agency, Arlington Hall Station, Arlington, VA.

105. Fenix and Scisson, Inc. Engineering, Construction, and Management Capabilities Publication, 1972 .

106. S. H. Woodcock, Consultant Report on Explosives, January 1973.

107. C. R. Graham, "World's Deepest We11: Plugged and Abandoned," The Petroleum Engineer, March 1959 .

108. L. G. Carter et a 1., "Expanding Cements for Primary Cementing," Journal of Petroleum Technology, May 1966 .

109. F. M. Empson and U. Tamura, "Plugging of Boreholes," Radioactive Waste Repository Project Annual Progress Report for Period Ending September 30, 1972, ORNL-4824, pp.19-23, December 1972 .

110. Oak Ridge National Laboratory unpublished data on Salt Mine Repository in Monthly Progress Report, June $29,1973$.

111. J. Handin, "Strength of $0 i 1$ Well Cements at Downhole Pressure-Temperature Conditions," Society of Petroleum Engineers Journal, December 1966 .
112. N. P. Chironis, "Plugging $01 \mathrm{~d}$ Gas and 0 il Wells Reduces Costs, Health Hazards," Coal Age, pp. 95-98, November 1972.

113. J. Pasini et al., U.S. Bureau of Mines, "Plugging Abandoned Gas and 0il Wells" Mining Con-

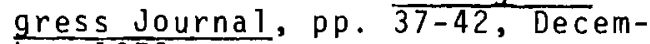
ber 1972 .

114. R. F. Walters, Walters Dril1ing Co., Consultant to BNWL, personal communication to J. R. Sheff, BattelleNorthwest Laboratory, Richland, WA, 1973.

115. R. L. Bradshaw, J. J. Perona, J. 0. Blomeke and

W. J. Boegly, Jr., Evaluation of Ultimate DisposaT Methods for Liquid and Solid Radioactive Wastes VI. Disposal of Solid wastes in Salt Formations, ORNL-3358 Rev., p. 23,

March 1969 .

116. Oak Ridge National Laboratory, Preliminary Safety Analys is Report, Federal Repository, Lyons, Kansas, USAEC Report ORNL-CF-10 Draft, to be published.

117. G. A. Clark, of Marathon 0 il Company, Findlay, $0 \mathrm{H}$, Letter proposal with enclosures sent to Or. F. K. Pittman, Division of Waste Management, AEC, Washington, $D C$, November 27 , 1972 .

118. D. A. Goolsby, "Hydrogeochemical Effects of Injecting Wastes into a Limestone Aquifer Near Pensacola, Fiorida," Ground Water, vol. 1. no. 13, 1971 .

119. D. A. Goolsby, US Geological Survey - Tallahassee, Florida, Personal Communication with J. R. Sheff, BattelleNorthwest, Richland, WA, November 1972 .

120. C. P. Neiswender, Monsanto Chemical Company, Pensacola, $\mathrm{FL}$, Personal Communication with J. R. Sheff, BattelleNorthwest, Richland, WA, November 1972 . 
121. M. J. Szulinski, Waste Management Special Studies - Progress Report No. 3, USAEC Report ARH-2437-C, Figure III-10, July 1972 .

122. C. T. Brandt, Fenix and Scisson, Inc., Letter proposal to E. G. Struxness at 0ak Ridge National Laboratory, November 1968.

123. F. K. Pittman, Management of Commercial High-Level Radioactive Waste, paper presented at summer course on Nuclear Fue 1 and Power Management, Massachusetts Institute of Technology, Cambridge, MA, July 25 , 1972 .

124. A. L. Boch et al., Radioactive Waste Repository Project, Annual Progress Report for Period Ending September 30, 1972, ORNL-4828, Oak Ridge Nationa 1 Laboratory, 0ak Ridge, TN, December 1972.

125. American Petroleum Institute, Problems in the Disposal of Radioactive Waste in Deep We $11 \mathrm{~s}$, American Petroleum Institute, Production Division, Dallas, TX, 1958 .

126. W. delaguna, "Disposal of Radioactive Wastes by Hydraulic Fracturing, Part 1, General Concept and First Field Experiments," Nuclear Engineering and Design, vol. 3, pp. 338-352, 1966 .

127. W. delaguna, "Disposal of Radioactive Wastes by Hydraulic Fracturing, Part II, Mechanics of Fracture Formation and Design and Observation and Monitoring Wells," Nuclear Engineering and Design, vol. 3, pp. 432-438, 1966 .

128. H. O. Weeren, "Disposal of Radioactive Wastes by Hydraulic Fracturing, Part III, Designing or ORNL's Shale Fracturing Plant," Nuclear Engineering and Design, vol. 4, pp. 108-117, 1966 .

129. T. Tamura, "Disposal of Radioactive Wastes by Hydraulic Fracturing, Part V, Site Evaluations," Nuclear Engineering and Design, vol. 9, pp. 315-326, 1969 .
130. W. C. McClain, "Disposal of Radioactive Wastes by Hydraulic Fracturing, Part V, Site Evaluations," Nuclear Engineering and Design, vol. 9, pp. 315-326, 1969 .

131. W. C. McClain, "Hydraulic Fracturing as a Waste Disposal Method," Disposal of Radioactive Wastes Into the Ground, International A tomic Energy Agency and European Nuclear Energy Agency, Symposium, Vienna, Austria, 1967.

132. W. C. McClain, "Disposal by Hydraulic Fracturing," Waste Treatment and Disposal SemiAnnua 1 Progress Report, JuTyDecember, 1966, ORNL-TM-1846, F. L. Parker and R. E. Blanco, Editors, Oak Ridge National Laboratory, Oak Ridge, TN, 1967.

133. W. C. McClain, "Disposal by Hydraulic Fracturing: Rock Mechanics, "Health Physics Division Annual Progess Report, Ju1y 31, 1966, ORNL-4007, Oak Ridge National Laboratory, Oak Ridge, TN, 1966.

134. W. delaguna et a 1 , Engineering Development of Hydraulic Fracturing as a Method for Permanent Disposal of Radioactive Wastes, USAEC report, ORNL-4259, Oak Ridge National Laboratory, Oak Ridge, TN, August 1968.

135. R. O. Van Everdingen and R. A. Freeze, Subsurface Disposal of Waste in Canada, Technical Bulletin No. 49, In 1 and Waters Branches, Department of the Environment, Ottawa, Canada, 1971 .

136. "Anadarko Claims Another Depth Record," 0il and Gas Formula, v01. 70, no. 8, pp.94-95, 1972

137. E. B. Ekren et al., Geologic and Hydrologic Considerations for Various Concepts of HighLevel Radioactive Waste Disposal in Conterminous United States, U.S. Geological Survey-2198-1, 1974 .

138. L. Obert and W. I. Duval1, Rock Mechanics and the Design of Structures in Rocks, John Wiley \& Sons, Inc., New York, NY, 1967. 
139. M. K. Hubbert and D. G. Willis, "Mechanics of Hydraulic Fracturing," Trans. AIME, vol. 210, pp. 153-168, 1957.

140. D. L. Katz and K. H. Coats, "Underground Storage of Flujds," Ulrich's Books, Inc., Ann Arbor, MI, 1968.

141. W. C. McClain, "Disposal by Hydraulic Fracturing: Rock Mechanics." Health Physics Division Annual Progress Report 31. ORNL-4168, Oak Ridge National Laboratory, 0ak Ridge, TN, p. 13, July 1967 .

142. R. 0. Kehle, "The Determination of Tectonic Stresses Through Analys is of Hydraulic Well Fracturing," Journal Geophysical Research, vol.69, no. 2, January 15, 1964.

143. Oak Ridge National Laboratory, Site Selection Factors for the Bedded Salt PiTot Plant, ORNLTM-4219, May 1973 .

144. D. E. White, Geothermal Energy, Geological Survey Circular 5t9, U.S. Geological Survey, 1969.

145. W. L. Lennemann, "Management of Radioactive Aqueous Waste from U.S. Atomic Energy Commission's Fuel Reprocessing Operations, Experience and Planning," Symposium IAEA/ENA on the Management of Radioactive Wastes from Fuel Reprocessing, Paris, France, November-December 1972.

146. J. H. Rubin, "The Nuclear Fuel Cycle and Waste Production," Symposium IAEA/ENA on the Management of Radioactive Wastes from FueT Reprocessing, Paris, France, November-December 1972.

147. D. E. Larson, High-Level Liquid Radioactive Waste Management Program, USAEC Report ARH-2400, Atiantic Richfield Hanford Company, Richland, WA, April 1972 .

148. D. E. Larson, Atlantic Richfield Hanford Company, Richland, WA, Telephone Communication to $W$. K. Winegardner, Battelle, Pacific Northwest Laboratory, Richland, WA, April 29, 1973.
149. T. K. Thompson et al., "Fluidized Bed Calcination of Radioactive Wastes Using In-Bed Combustion Heating," Nuclear Technology, vol. 16, November 1972 .

150. J. L. McElroy et al., Waste Solidification Program Summary Report, Volume I1, EvaTuation of WSEP High-Level Waste SoTidification Processes, USAEC Report BNWL-1667, Battelle, Pacific Northwest Laboratory, Richland, WA, July 1972.

151. L. T. Lakey et a 1., ICPP Waste Calcining Facility safety AnaTysis Report, USAEC Report TDO14620 , December 1963.

152. J. E. Mendel and J. L. MCElroy, Waste Solidification Program, Volume 10, Evaluation of Solidified Waste Products, USAEC Report BNWL-1666, Battelle, Pacific Northwest Laboratory, Richland, WA, July 1972 .

153. Waste Management Special Studies Progress Reports, USAEC Reports ARH-2437-J, At lantic Richfield Hanford Company, Richland, WA, 1972-73.

154. Code of Federal Regulations, lOCFR Part 71, office of the Federal Register, G.S.A.

155. Code of Federal Regulations, 49CFR Parts 170 through 179, Office of the Federal Register G.S.A.

156. J. J. Perona et al., Design and Safety Considerations of Shipping Solidified High-Level Radioactive Wastes, USAEC Report ORNL-TM-297i, Oak Ridge National Laboratory, Oak Ridge, TN, December 1970.

157. G. C. Mathis, Fenix and Scisson, Inc., Personal Communication with K. J. Schneider, Battelle-Northwest, Richland, WA, December 1972.

158. D. E. Rasmussen, BattelleNorthwest, Personal Communication with J.R. Sheff, Battelle-Northwest, Richland, WA, January 1973. 
159. D. E. Larson, Atlantic Richfield Hanford Co., Richland, WA, Telephone Communication to J. R. Sheff, Battelle-Northwest, Richland, WA, January 3, 1973.

160. R. Peele, Mining Engineers Handbook, Third Edition, John Wiley and Sons, New York, NY, 1941 .

161. K. Thirumalai, Twin Cities Mining Research Center, Twin Cities, MN, Telephone Communication to M. R. Kreiter, Battelle-Northwest, Richland, WA, July 25, 1973.

162. G. Jansen, Advanced Waste Management Studies - Progress Report, June-JuTy T972, USAEC Report, BNWL-B-223-1.

163. R. E. Isaacson and L. E. Browne11, U1timate Storage of Radioactive Wastes in Terrestrial Environments, AEC Report ARH-SA-T26, P. 6, August 1972 .

164. M. J. Bell and R. S. Dillon, The Long-Term Hazard of Radioactive Wastes Produced by the Enriched Uranium Pu-238U and 233U-Th Fuel Cyctes, USAEC Report, ORNL-TM-3548, 1971. And unpublished ORIGEN calculations by D. E. Deonigi et a1., Batte11e-Northwest, January 1973.
165. L. L. Ames, Battelle-Northwest, Personal Communication to J. R. Sheff, BattelleNorthwest, January 1973.

166. K. J. Schneider, "Solidification and Disposal of High-Level Radioactive Wastes in the United States," Reactor Technology, vol. 13, p. 391, 1970-1971.

167. Code of Federal Regulations, TOCFR Part 50 Appendix F, Office of the Federal Register, G.S.A.

168. R. Y. Lyon, Editor, Waste Management Special studies, Progress Report No. 7, February 1, 1973 to March 37, 1973, USAEC Report ARH-2437 G, March 1973.

169. R. D. Cheverton and W. D. Turner, Thermal Analys is National Radioactive Waste Repository: Progress through March 1972, USAEC Report ORNL-4789, Oak Ridge National Laboratory, Oak Ridge, TN, September 1972 . 


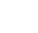

.

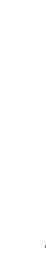

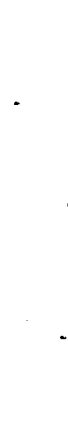

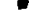


BNWL-1900

APPENDIX

SECTION 4: GEOLOGIC DISPOSAL

$\checkmark$ 
APPENDIX 4.A

GLOSSARY OF GEOHYOROLOGIC TERMS 


\section{GLOSSARY OF GEOHYDROLOGIC TERMS}

Technical terms, particularly those with somewhat obscure meanings, are defined in this glossary. For terms not defined in this glossary the reader is referred to the "Glossary of Geology and Related Sciences," compiled by the American Geological Institute, and Webster's New World Dictionary, College Edition.

In some instances, definitions have been enlarged beyond the standard textbook definitions. No attempt has been made to cite the source of definitions, and those definitions that have been enlarged may deviate slightly from the standard definitions.

Alluvial fan. A sloping, fanshaped mass of loose rock material deposited by a stream at the place where it emerges from an upland into a broad valley or a plain.

Alluvium. All detrital material deposited permanently or in transit by streams.

Amphibole. A group of dark, rockforming, ferromagnesian silicate minerals which are closely related in crystal form and composition and which have abundant and wide distribution in igneous and metamorphic rocks.

Anorthosite. A granular plutonic igneous rock composed almost exclusively of soda-lime feldspar.

Anion. An ion that is negatively charged.

Anticline. A fold, the core of which contains stratigraphically older rocks, and which in simplest form, is elongate and convex upward with the two 1 imbs dipping away from each other.

Aquifer. A formation, group of formations, or part of a formation that contains sufficient saturated permeable material to yield significant quantities of water to wells and springs.

Aquitard. A natural rock or finegrained, unconsolidated unit of low permeability which is stratigraphically adjacent to one or more aquifers and through which water movement is markedly retarded or impeded.

Argillite. A compact rock, derived from claystone, siltstone, or shale, which has undergone a somewhat higher degree of induration than is present in these sedimentary rock types but which is less clearly laminated than shale, does not have the fissibility of shale, and lacks the cleavage distinctive of slate.

Artesian. Pertaining to an aquifer is one that is confined so that its hydraulic head rises above the top of the aquifer unit; thus an artesian water body is one confined and under hydraulic pressure.

Basement. A complex of undifferentiated rocks that underlies the oldest identifiable rocks in the area.

Basin. A depressed area generally having no surface outlet; a segment of the earth's crust that has been downwarped by the accumulation of sediments on it; a synclinal tract or area in which the rocks dip toward a central point, and in which folding 
occurred subsequent to deposition; an elongate, fault-bordered intermountain area.

Batholith. An igneous intrusion greater than 40 square miles in surface exposure, composed predominantly of granitic rocks.

Bauxite. A rock composed of an impure mixture of earthy hydrous aluminum oxides and hydroxides and is the principal commercial source of a luminum.

Bentonitic. Pertaining to a rock containing bentonite, a clay formed from the decomposition of volcanic ash.

Biotite. A complex silicate of a luminum, potassium, magnesium, and iron with hydroxyl that is a widely distributed and important rock-forming mineral of the mica group.

Block-faulting. A type of vertical faulting in which the crust is divided into structural or fault blocks of different elevations and orientations.

Brackish. A somewhat general term applied to mineralized water of concentrations intermediate between those of brine and fresh water.

Breccia. A coarse-grained clastic rock composed of large, angular, and broken rock fragments cemented together in a fine-grained matrix.

Caliche. Calcareous material that forms on or near the surface of stony soils of arid and semiarid regions; thought to be genetically associated locally with capillary fringe of the water table; and is inferred to form when evaporation exceeds precipitation.
Cap rock. A low-permeability body of anhydrite and gypsum which overlies a salt body, or plug in a salt dome.

Cation. An ion that is positively charged.

Chimneying. The process of progressive collapse of rock overlying an explosion-produced cavity resulting in a tall underground cylinder (chimney) of broken rock.

Chlorite. A group of green hydrous silicate minerals containing magnesium and iron, with or without aluminum; that these minerals are widely distributed, especially in metamorphic rocks.

clastic. Pertaining to or being a rock or sediment composed principally of broken fragments derived from preexisting rocks or minerals.

cleavage. The property or tendency of a rock to split along secondary, aligned fractures or other closely spaced, planar surfaces, produced by deformation or metamorphism.

Coal measures. A succession of sedimentary rocks (or measures) consisting of clays or shales, sandstones, 1 imestones, and conglomerates with interstratified beds of coal; a group of coal seams interbedded with the above strata.

Conglomerate. A coarse-grained clastic sedimentary rock composed of rounded to subangular fragments larger than $2 \mathrm{~mm}$ in diameter, such as granules, pebbles, cobbles, and boulders, set in a fine-grained matrix of sand, silt, or cementing materials, such as calcium carbonate, iron oxide, and silica. The consolidated equivalent of gravel. 
Consolidated (material). In geology, natural materials that have been made firm, cohesive, and hard.

crystalline rock. An inexact but convenient term designating an igneous or metamorphic rock, as opposed to a sedimentary rock.

Depositional environment (sedimentary environment). A geographically restricted environment where sediment accumulates under similar physical, chemical, and biological conditions.

Diagenesis. Process involving physical and chemical changes in sediment after deposition that converts the sediment to consolidated rock.

Diamond pipe. Term used for an occurrence of kimberlite (periodotite that has been converted to a hydrous magnesian silicate) in volcanic pipes large enough and sufficiently diamond bearing to be minable.

Diapirism. The piercing of overlying rocks by a mobile core, such as a salt body or an igneous intrusion.

Discharge. In groundwater hydrology, water that issues naturally or is withdrawn from an aquifer.

Dome. A dome-shaped landform or rock mass; a large igneous intrusion whose surface is convex upward with sides sloping away at low but gradually increasing angles; an uplift or an anticlinaltype structure, either circular or elliptical in outline, in which the rock dips gently away in all directions, for example, a salt dome.

Dunite. A coarse-grained plutonic igneous rock composed almost entirely of olivine.

Ephemeral stream. A water course carrying surface water part of the time but dry or having only underflow in the streambed materials part of the time.

Epidote. A basic orthosilicate mineral containing calcium, aluminum, and varying amounts of iron, and commonly occurring in metamorphic rocks.

Fault. A fracture or fracture zone along which there has been displacement of the sides relative to one another parallel to the fracture.

Fault block. A crustal unit bounded by faults, either completely or partiy.

Fault system. A system of parallel faults that are related to a particular deformational episode.

Feldspar. Any of an important group of rock-forming minerals that are essentially silicates of alumina and some other base, such as potash, soda, or lime.

Flood-plain deposit. Sandy and clayey sediment deposited by river water that spread out over a flood pla in.

Foliation. A general term for a planar arrangement of textural or structural features in any rock type, but most commonly applied to metamorphic rocks, such as cleavage in slate or schistosity in a metamorphic rock.

Garnet. An important group of silicate minerals rich in alumina, iron, lime, and magnesia that occur chiefly as accessory constituents of metamorphic rocks and less commonly of igneous rocks.

Geohydrologic. of or pertaining to the geology and hydrology. An abbreviation combining the adjectives geologic and hydrologic. 
Geoid. The figure of the earth considered as a mean sea-level surface extended continuously through the continents.

Geotherma 1. Pertaining to the heat of the interior of the earth.

Glacial outwash gravel. Gravel removed or "washed out" from a glacier by meltwater streams and deposited in front or beyond the margin of an active glacier.

Graben. An elongate, relatively depressed crustal unit or block bounded by faults on its long sides.

Granitic. of or pertaining to granite. Granite-like.

Granitoid. A textural term indicating grain size and mineral distribution typical of granite.

Hornblende. A common member of the amphibole group of minerals.

Hydraulic gradient. The change in static head per unit of lateral distance in a given direction.

Hydrostatic pressure. The pressure exerted by the water at any given point in a body of water at rest.

Hydrotherma 1. A term applied to heated or hot magmatic emanations rich in water and applied to the rocks, ore deposits, alteration products, and springs produced by hydrothermal processes.

Ion exchange. Replacement of ions adsorbed on a solid--such as a clay particle--or exposed at the surface of a solid by ions from solution, usually in natural water. The phenomenon is known to occur when natural water moves through clays, zeolitic rocks, and other materials of the earth's crust.
Interfluve. The area between adjacent streams flowing in the same general direction.

Interstices. In geology, small openings between solid particles in a rock or unconsolidated material; may be a void or pore and often contains groundwater. Interstitial permeabi1-ity is used to differentiate interconnected pore permeability from fracture permeability.

Iron formation. A chemical sedimentary rock, typically thin-bedded and (or) finely laminated, containing at least 15 percent iron of sedimentary origin.

Isopach. A line drawn on a map through points of equal thickness of a designated stratigraphic unit or group of stratigraphic units.

Joint. A fracture or parting in a rock, without displacement.

Kaolinite. The mineral characteristic of kaolin, a group of minerals consisting essentially of hydrous luminum silicate and which are closely related in chemical composition and crystal structure.

Laccolith. A concordant igneous intrusion with a known or assumed flat floor and a postulated dikelike feeder somewhere beneath its thickest point.

Lithification. The conversion of unconsolidated sediment into solid rock by processes such as compaction, cementation, and crystallization.

Lithology. The character of a rock (described in terms of) its structure, color, mineral composition, grain-size, and arrangement of its component parts. 
Loess. An unconsolidated or weakly consolidated sedimentary deposit which is composed dominantly of silt-sized rock and mineral particles and which is deposited by wind.

Low-angle fault. A fault, the dip of which is no more than $45^{\circ}$ (or less).

Mafic. Pertaining to or composed dominantly of magnesium rock-forming silicates.

Magmatism. The development, movement, and solidification to igneous rock, of magma, a naturally occurring mobile rock material, generated within the earth and capable of intrusion and extrusion.

Matrix-hole concept. A type of radioactive water repository consisting of several drill holes spaced moderately close together.

Mesa. An isolated, nearly level landmass standing distinctiy above the surrounding country, bounded by steeply sloping erosion scarps on all sides, and capped by layers of resistant, nearly horizontal rocks.

Metallic. Of or belonging to metals, containing metals, more particularly, valuable metals that are the object of mining ore.

Mica. A group of silicate minerals of aluminum and other bases, especially potassium, magnesium, and iron, and characterized by a great perfection of cleavage in one direction that produces thin, though, elastic plates or laminae.

Monocline. A unit of strata that dips from the horizontal in one direction only, and is not part of an anticline or syncline.
Nepheline syenite. A plutonic rock composed almost entirely of alkali-feldspar and nepheline which is a silicate mineral containing appreciable amounts of potash, soda, and alumina.

olivine. An olive-green, common rock-forming ferromagnesian silicate mineral of mafic, ultramafic, and lowsilica igneous rocks.

outcrop. A part of a body of rock that appears, bare and exposed, at the surface of the ground.

Permeability (permeable). The relative ease with which a porous medium can transmit a liquid under a hydraulic gradient.

Plagioclase. The group of common rock-forming feldspar minerals that contain varying mixtures of sodium and calcium.

Playa. A flat-floored area composed of thin, evenly stratified sheets of fine clay, silt, or sand, and representing the lowermost or central part of a shallow completely closed or undrained, desert lake basin in which water accumulates after a rain and is evaporated, usually leaving deposits of soluble salts.

Peridotite. A coarse-grained plutonic igneous rock composed chiefly of the mineral olivine but also containing considerable amounts of other ferromagnesian minerals.

Pluton. A body of intrusive igneous rock of any shape or size.

Pluvial (period). Pertaining to a period of time or a climate in which rainfall or precipitation is abundant.

Porosity. That property of a rock or soil which enables the rock or 
soil to contain water in voids or interstices, usually expressed in percentage or a decimal fraction of void volume as compared to total volume.

Pyroxene. A group of dark, rockforming silicate minerals closely related in crystal form and analogous in chemical composition to the amphiboles, and found chiefly in igneous rocks.

Pyroxenite. An ultramafic plutonic igneous rock chiefly composed of pyroxene.

Quartz monzonite. A coarsegrained igneous rock, intermediate in composition between granjte and granodiorite, which contains quartz and about equal amounts of the alkali and soda-lime feldspars.

Recharge. In hydrology, a source or means for replenishment of water withdrawn or discharged from an aquifer. An aquifer in hydraulic equilibrium will discharge a quantity of water about equal to the amount of recharge.

Rift. A long fairly relative narrow depression formed along lines of multiple fracture.

Rift valley. An elongate narrow trough or valley formed by the sinking of a strip of the earth's crust between two more or less parallel nearly vertical faults.

Rift zone. A system of crustal fractures.

Rise (marine). A broad, elongate, and smooth elevation of the ocean floor.

Sedimentary basin. Geologically depressed area with thick sediments in the interior and thinner sediments at the edges.
Seismicity. The phenomenon of earth movements as manifested by earthquakes.

Shield. A continental segment of the earth's crust which has been relatively stable over a long period of time and which has exposed crystalline rocks mostly of Precambrian age; in general, representing the oldest rocks of the continent.

sill. A tabular igneous intrusion that parallels the planar structure of the surrounding rock.

Sink hole. A funnel-shaped depression in the land surface generally in a limestone region often connected to a subterranean passage developed by solution.

Static head. The height above a standard datum of the surface of a column of water (or other liquid) that can be supported by the static pressure at a given point.

stock. An igneous intrustion less than 40 square miles in surface exposure.

Strain. Deformation resulting from applied stress; proportional to stress.

Stratum. A single layer of homogeneous or gradational lithology, deposited parallel to the original dip of the formation.

Strike-slip fault. A fault, the actual movement of which is parallel to the strike of the fault.

syncline. A fold, the core of which contains stratigraphically younger rocks, and which in simplest form, is elongate and concave upward with the two 1 imbs dipping toward each other. 
Tectonic. Pertaining to the forces involved in, or the rock structures and external forms resulting from the deformation of the earth's crust.

Tectonism (diastrophism). Crustal movement produced by earth forces, such as the formation of plateaus and mountain ranges; the structural behavior of an element of the earth's crust during, or between, major cycles of sedimentation.

Terrace. A long, narrow, relatively level or gently inclined surface, generally less broad than a plain, bounded along one edge by a steeper descending slope and along the other by a steeper ascending slope, and containing unconsolidated material.

Thrust fault. A fault with a dip of $45^{\circ}$ or less in which the upper rock mass appears to have moved upward relative to the lower rock mass.

Transmissivity. Volume of water flowing through a one-foot width of aquifer of given thickness under a unit gradient (one foot vertically for each foot lateraliy) and at the viscosity prevailing in the field. Mathematically, it is the product of permeability and aquifer thickness.

U1tramafic. Pertaining to igneous rocks composed chiefly of ferromagnesian, dark minerals.

Underthrust. A type of thrust fault in which the lower rock mass has been actively moved under the upper, passive rock mass.

Uplift. A structurally high area in the crust, produced by positive movements that raise or upthrust the rocks, as in a dome or arch.

Upwarping. Uplift of a regional area of the earth's crust.

Water table. That surface of an unconfined water body at which the pressure is atmospheric.

Zeolite. Any of a large group of minerals that are hydrous silicates of aluminum with sodium and calcium, or rarely, with barium and strontium.

zeolitization. The process by which feldspars and other alumino silicates of a rock are altered to zeolites. 
APPENDIX 4.B

MAJOR STRATIGRAPHIC AND TIME DIVISIONS 
Major Stratigraphic and Time Divisions

[B̈y Geol. Names Conmittee, U.S. Geol. Survey, 1972 7

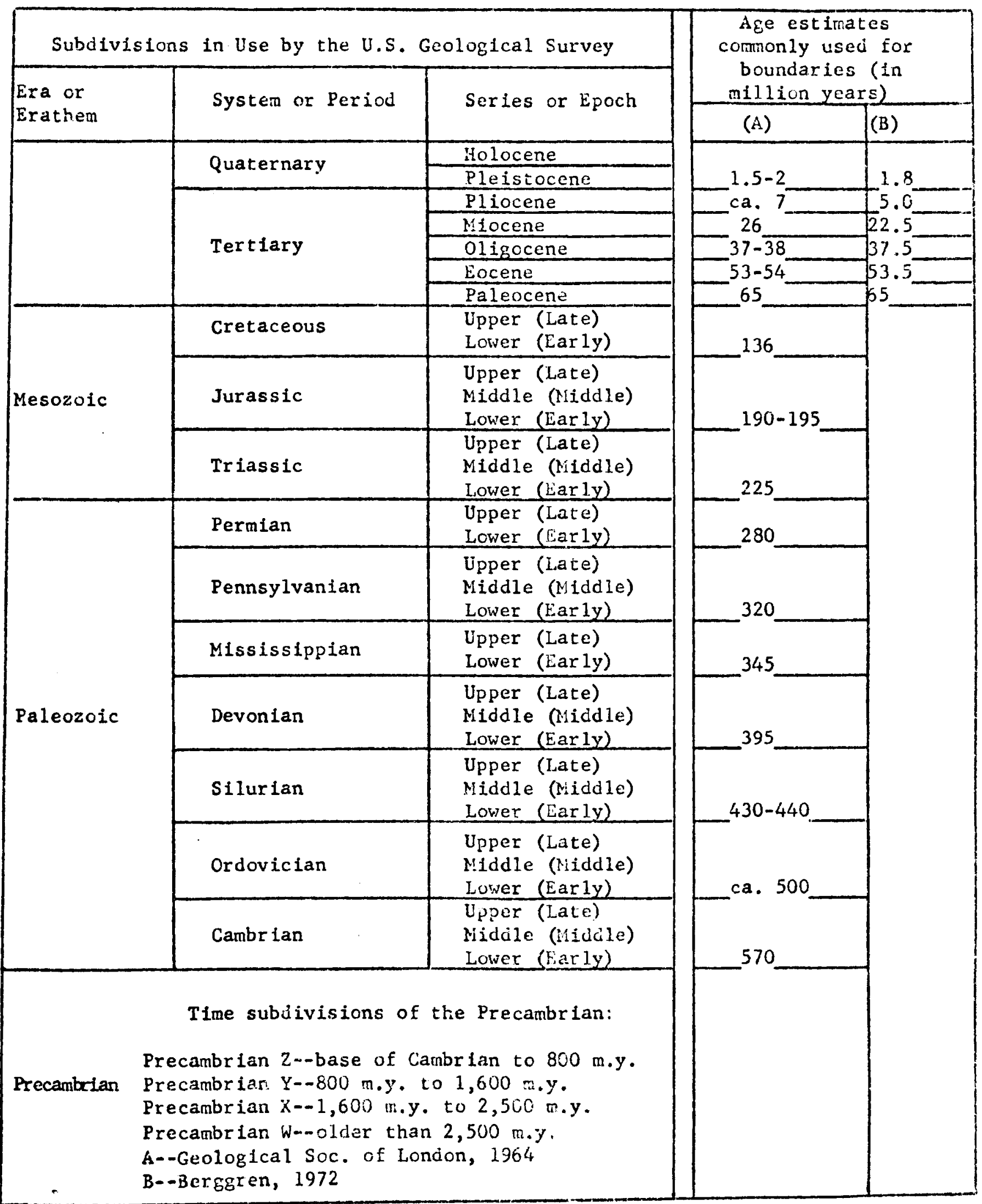


APPENDIX $4 . \mathrm{C}$

CHEMICAL COMPOSITIONS (IN PERCENT) AND PHYSICAL

AND HYDROLOGIC PROPERTIES OF PRINCIPAL ROCK TYPES 


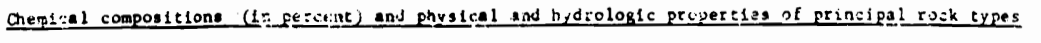

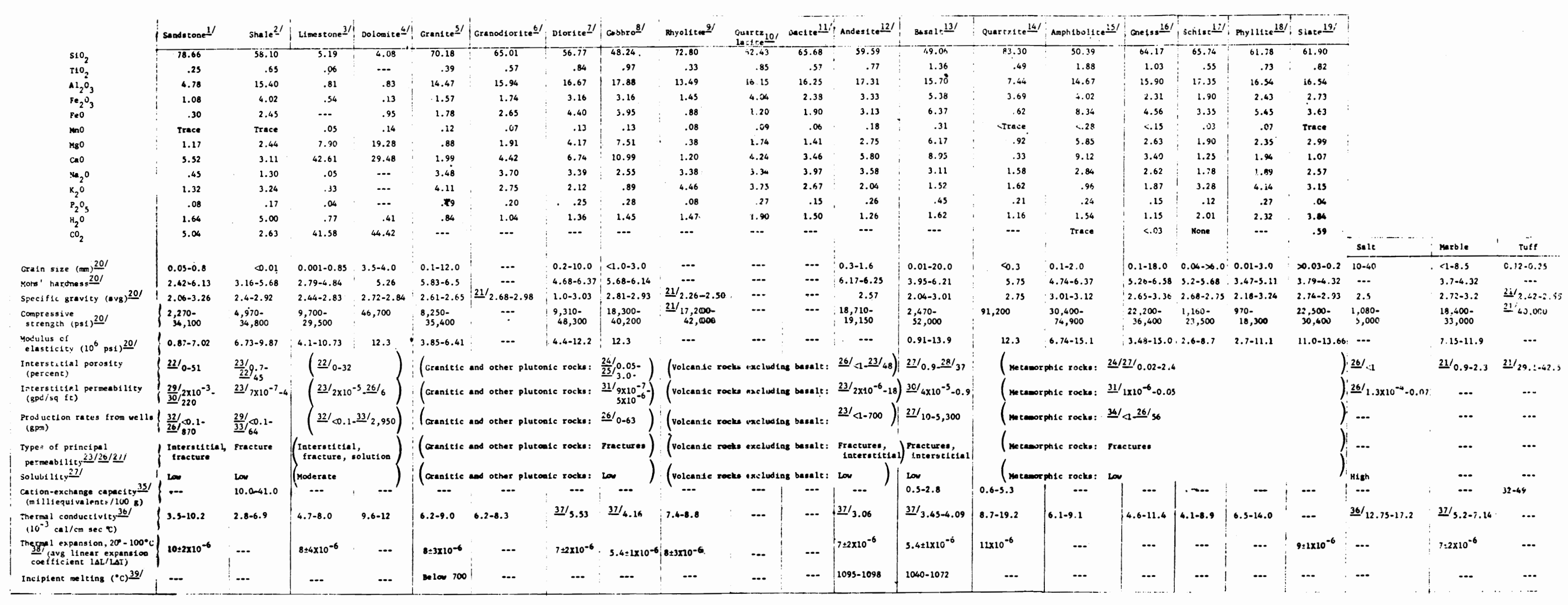

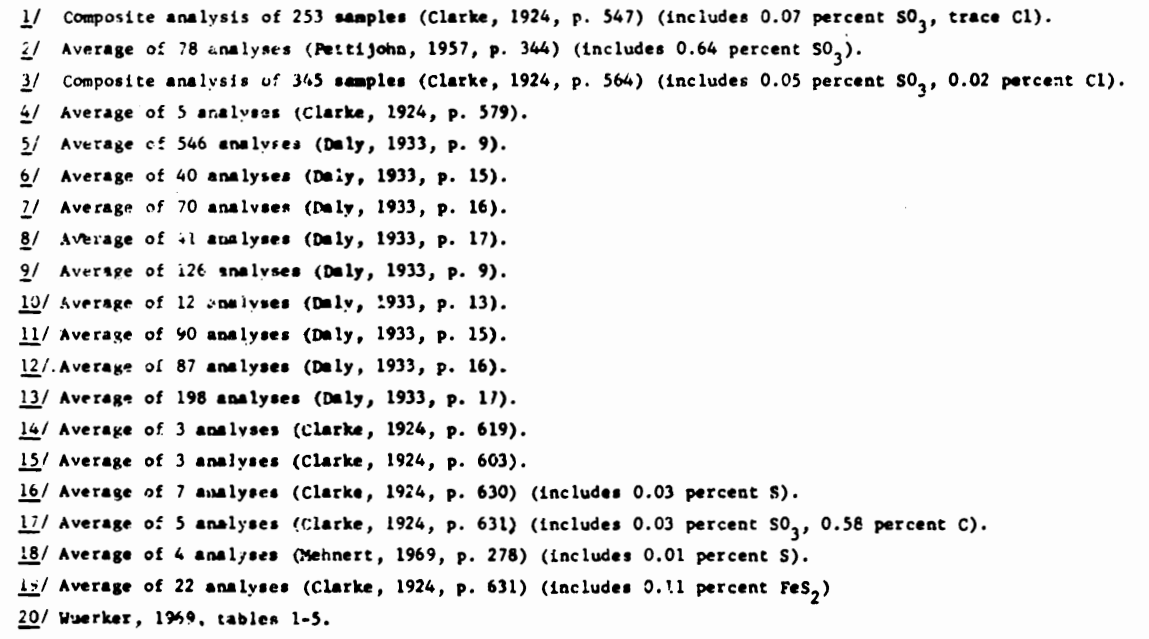

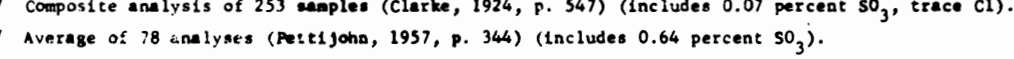

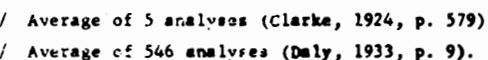

Averase of 70 a

Avernge of

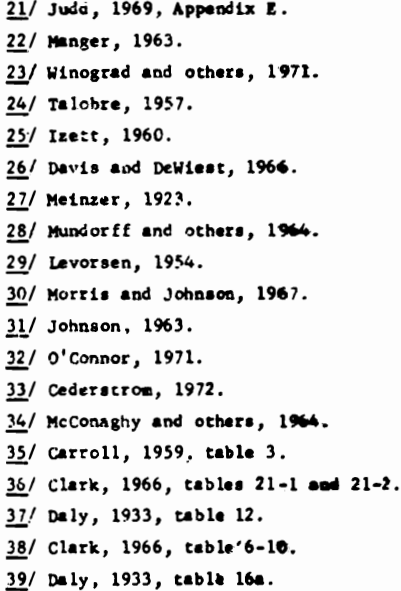

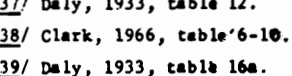




$$
\text { 4.D. } 1
$$

Table 7. Abridged Version of Modified Mercalli Intensity Scale of 1931 (Coffman and von Hake, 1972, p. 4-7)

I. Not felt except by a very few under specially favorable circumstances. (I)

II. Felt only by a few persons at rest, especially on upper floors of buildings. Delicately suspended objects may swing. (I to II)

III. Felt quite noticeably indoors, especially on upper floors of buildings, but many people do not recognize it as an earthquake. Standing motorcars may rock slightly. Vibration like passing of truck. Duration estimated. (III)

IV. During the day, felt indoors by many, outdoors by few. At night, some awakened. Dishes, windows, doors disturbed; walls made creaking sound. Sensation like heavy truck striking building. Standing motorcars rocked noticeably. (IV to V)

V. Felt by nearly everyone, many awakened. Some dishes, windows, etc., broken; a few instances of cracked plaster; unstable objects overturned. Disturbances of trees, poles, and other tall objects sometimes noticed. Pendulum clocks may stop. (V to VI)

VI. Felt by a 11, many frightened and run outdoors. Some heavy furniture moved; a few instances of fallen plaster or damaged chimneys. Damage slight. (VI to VII)

VII. Everybody runs outdoors. Damage negligible in buildings of good design and construction; slight to moderate in well-built ordinary structures; considerable in poorly built or badly designed structures; some chimneys broken. Noticed by persons driving motorcars. (VIII-) 


\section{D.2}

TABLE 7. (contd)

VIII. Damage slight in specially designed structures; considerable in ordinary, substantial buildings, with partial collapse; great in poorly built structures. Panel walls thrown out of frame structures. Fall of chimneys, factory stacks, columns, monuments, walls. Heavy furniture overturned. Sand and mud ejected in small amounts. Changes in well water. Persons driving motorcars disturbed. (VIII+ to IX)

IX. Damage considerable in specially designed structures; we11designed frame structures thrown out of plumb; great in substantial buildings, with partial collapse. Buildings shifted off foundations. Ground cracked conspicuously. Underground pipes broken. $(I X+)$

$x$. Some we11-built wooden structures destroyed; most masonry and frame structures destroyed with their foundations; ground badly cracked. Rails bent. Landslides considerable from river banks and steep slopes. Shifted sand and mud. Water splashed (slopped) over banks. (X)

XI. Few, if any, (masonry) structures remain standing. Bridges destroyed. Broad fissures in ground. Underground pipelines completely out of service. Earth slumps and land slips in soft ground. Rails bent greatly.

XII. Damage total. Waves seen on ground surfaces. Lines of sight and level distorted. Objects thrown upward into air. 
APPENDIX $4 . E$

PROMINENT EARTHQUAKES IN THE UNITED STATES THROUGH 1970 


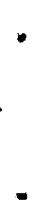




\section{APPENDIX $4 . E$}

Yrominent earthquakes in the vnited states through 1970 (Coffinan and von iake, 1972, p. 6)

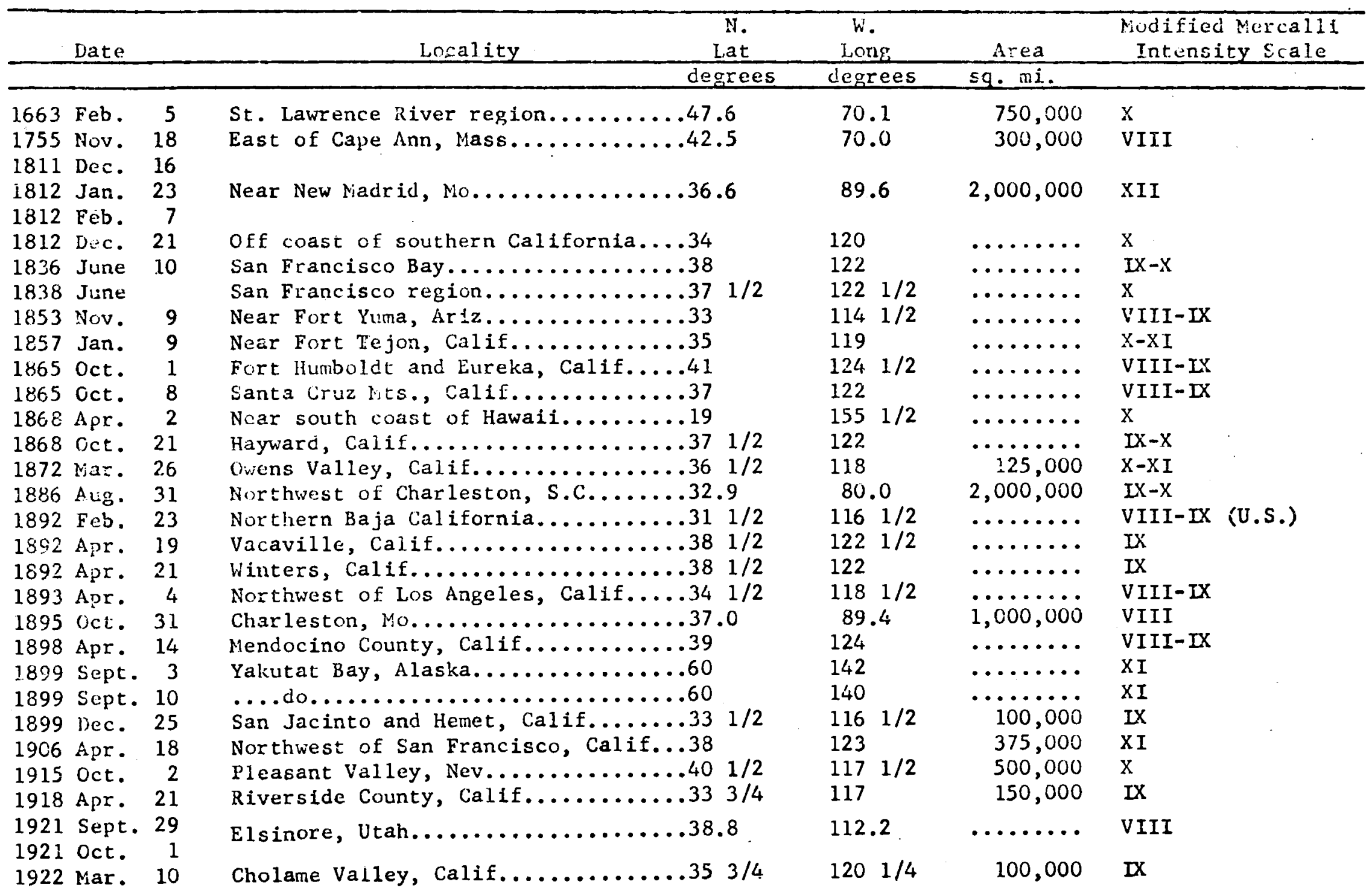


APPENDIX $4 . E$ (contd)

Prominent earthquakes in the United States through 1970--Cont inued

\begin{tabular}{|c|c|c|c|c|c|c|}
\hline & \multicolumn{2}{|l|}{ Date } & \multirow[t]{2}{*}{ Localicy } & $\begin{array}{l}\text { W. } \\
\text { Long }\end{array}$ & \multirow{2}{*}{ Area } & \multirow[t]{2}{*}{$\begin{array}{l}\text { Modified tiercalli } \\
\text { Intenslty Scale }\end{array}$} \\
\hline & & & & denrees & & \\
\hline 1925 & $\mathrm{Feb}$. & 28 & St. Lawrence River region........47.6 & 70.1 & $2,000,000$ & VIII \\
\hline 1925 & June & 27 & Helena, Mont................46.0 & 111.2 & 310,000 & VIII \\
\hline 1925 & June & 29 & Santa Barbara, Calif.............3/..3 & 119.8 & $\ldots \ldots \ldots$ & VIII-IX \\
\hline 1927 & Nov. & 4 & West of Point Argue11o, Calif......34 1/2 & $1211 / 2$ & $\ldots \ldots \ldots$ & IX $-\mathrm{X}$ \\
\hline 1931 & Aug. & 16 & Western Texas...................... 30.6 & 104.1 & 450,000 & VIII \\
\hline 1932 & Dec. & 20 & Hestern Nevada................... 38.7 & 117.8 & 500,000 & $\mathrm{X}$ \\
\hline 1933 & Mar. & 10 & Long Beach, Calif..............33.6 & 118.0 & 100,000 & IX \\
\hline 1934 & Jan. & 30 & Southeast of Hawthorne, Nev.......38.3 & 118.4 & 110,000 & VIII-IX \\
\hline 1934 & Mar. & 12 & Near Kosmo, Utah..............41.7 & 112.8 & 170,000 & VIII \\
\hline 1935 & Oct. & 18 & Northeast of Helena, Mont........46.6 & 112.0 & 230,000 & VIII \\
\hline $1935^{\circ}$ & Oct. & 31 & $\ldots$. do..................46.6 & 112.00 & 140,000 & VIII \\
\hline 1940 & May & 18 & Southeast of El Centro, Cal1f......32.7 & 115.5 & 60,000 & $\mathrm{X}$ \\
\hline 1949 & Apr. & 13 & Hestern Washington............47.1 & 122.7 & 150,000 & VIII \\
\hline 1952 & July & 21 & Kern County, Calif............35.0 & 119.0 & 160,000 & $X I$ \\
\hline 1954 & July & 6 & East of Fallon, Nev..............39.4 & 118.5 & 130,000 & IX \\
\hline 1954 & Aug. & 23 & $\ldots$............................... & 118.5 & 150,000 & IX \\
\hline 1954 & Dec. & 16 & Dixie Valley, Nev...............39.3 & $118: 2$ & 200,000 & $\mathrm{X}$ \\
\hline 1958 & July & 9 & Scutheastern Alaska............58.6 & 137.1 & 100,000 & XI \\
\hline 1959 & Aug. & 17 & Near Hebgen Lake, Mont...........44.8 & 111.1 & 600,000 & $\mathrm{X}$ \\
\hline 1964 & Mar. & 27 & Southern Alaska..............61.0 & 147.8 & 700,000 & $\mathrm{IX}-\mathrm{X}$ \\
\hline 1965 & Apr. & 29 & Northwestern Washington.........47.4 & 122.3 & 130,000 & VIII \\
\hline
\end{tabular}


BNWL- 1900

APPENDIX $4 . F$

DESCRIPTION OF SYSTEMS FOR COST BASES 


\section{APPENDIX 4.F}

\section{DESCRIPTION OF SYSTEMS FOR COST BASES}

Listings of conceptual facility, major equipment, and operating requirements for each of the geologic disposal concepts are contained in this appendix. The listings were prepared to provide bases for preliminary estimates of capital and operating costs associated with individual concepts. Costing of the various concepts was not intended to be exact because of the lack of definition of a specific site and detailed repository design. Thus the cost bases developed here provide sufficient information for approximate cost estimates and for estimating relative costs among various concepts. Section 3.2.3.1 of Section 3 in volume 1 of this report enumerates in more detail the cost bases for various depths and types of rock.

It is assumed that 14,500 canisters (30 centimeters outside diameter by 3 meters $10 \mathrm{ng}$ ), resulting from 25 years of operation of the reference 5 MT/day fuel reprocessing plant $(45,625$ metric tons of fuel equivalent) will be handled and buried. Maximum burial activity will be 20 canisters per week. Waste volume and maximum heat generation per canister are $0.18 \mathrm{~m}^{3}$ and $3.39 \mathrm{kilowatts}$, respectively.

For the liquid disposal concepts, the waste, piped from the reference on-site fuel reprocessing plant, will be available at an average rate of 1900 liters per day.

A standard buffer zone of 3.2 kilometers is expected to surround the disposal site.

Solid Waste Emplaced in Mined Cavity - No Fluid Cooling or Melting (Concept 1)

Capital cost estimates are based on a reference wherein waste canisters would be buried in the floor of a tunnel complex located inside a thick granite formation. The top of the granite formation is located at or near ground level while the working level of the mine is assumed to be located 600 meters below grade. Dimensions of major facilities and buildings and major equipment are summarized in Table 4.41. Additional details are presented below:

Surface facilities. Surface facilities include surge "tailing" storage, two hot cells, and the following concrete block/steel roof buildings: The receiving facility, hoist house, protection for ventilation fans and filters, and offices and laboratories (see Table 4.41). The receiving facility is equipped with a 100-ton-capacity bridge crane for cask handing. Canisters and cell cover blocks are manipulated with the aid of a 15 -ton in-cell crane. In the cell, the cask is transferred through the transfer gallery to beneath the hatch (cover block) of the transfer cell with a remotely operated transfer cart (the unit can also be used to raise the cask to form a seal against the underside of the cell during canister removal). The two surface hot cells are equipped with six viewing windows and six pairs of slave manipulators. 
TABLE 4.41. Facility Details for Cost Estimating Solid Waste Emplaced in Mined Cavity No Fluid Cooling or Melting

\section{Overall Facility Description}

Concrete block/steel roof construction

- Rail car air 1ock: $(45 \times 6) \times 14$ meters high

- Hoist house: $(9 \times 9) \times 6$ meters high

- Ventilation building: $(12 \times 12) \times 5$ meters high

- Offices, laboratories, etc.: $(30 \times 12) \times 5$ meters high

- Total area: 880 square meters

Hot cells

- Shielding is $1.2 \mathrm{~m}$ thick high-density concrete

- Transfer gallery: $(15 \times 8) \times 8$ meters high

- Transfer cel1: $(15 \times 15) \times 6$ meters high

- Mine-level receiving station: $(15 \times 15) \times 6$ meters high

- Total area: 580 square meters

Shafts (all concrete and steel lined)

- Transfer shaft: $0.6 \mathrm{~m} \mathrm{I.D.}$

- Ventilation shaft: $1.8 \mathrm{~m} \mathrm{I.D.}$

- Auxiliary shaft: $1.5 \mathrm{mI}$ I.D.

- Personnel shaft: $1.8 \mathrm{~m} \mathrm{I.D.}$

Tunnels

- Approximately $2.4 \mathrm{~km}^{2}$ square tunnel complex with a $3.2 \mathrm{~km}$ buffer zone surrounding the complex, or approximately $65 \mathrm{~km}^{2}$ of area

- Lattice spacing of canisters: $30 \mathrm{~m}$ (triangular)

- Burial tunnels: approximately 90 kilometers, 4.6 meters high $\times 4.6$ meters

- Access tunnels: approximately 11 kilometers

- Ventilation tunnels: $0.6 \mathrm{~m}$ I.D.

Major Equipment

100 and 15 ton bridge cranes at surface

23,600 liters/sec mine ventilation system with fans, high efficiency (HEPA) fi 7 ters, and prefilters

Transfer shaft hoist (elevator) $-150 \mathrm{~m} / \mathrm{min} 1 \mathrm{ift}$ speed, cable tension $11,000 \mathrm{~kg}$

Underground transporter; rubber tired, diesel power unit; shielded 35 -ton movable cask $22.9 \mathrm{~cm}$ lead shielding; $38.1 \mathrm{~cm}$ bore; $3.7 \mathrm{~m}$ long; 5 -ton hoist

6 viewing windows and pairs of manipulators

In-cell transfer carts - two required, remotely controlled, electric/hydraulic units

Mining rig including belt conveyors, shuttle cars, hole drilling rig, etc.

one bulkhead per individual burial tunne]

\section{Operating Data}

Staff: 11 supervisory, 23 nonsupervisory

- Administration: 4 supervisory, 10 nonsupervisory (including 5 security guards)

- Engineering: 5 supervisory, 5 nonsupervisory

- Operations: 2 supervisory, 8 nonsupervisory

operation: 5 day week, 1 shift 
Subsurface facilities. In addition to the tunnel complex and mining equipment, subsurface facilities and components include the transfer shaft and associated hoist; ventilation shaft; personnel and auxiliary shafts; the working (mine) level receiving station; and the shielded underground transporter. The transfer shaft hoist is an "elevator" designed to assure safe lowering of canisters. The working-level receiving station is a hot cell equipped with an in-cell transfer cart operated from four viewing window/manipulator stations. The underground transporter removes canisters from the receiving station and transports them to the disposal tunnels where the canisters are lowered into holes in the tunnel floor.

The mine-level receiving station is located at the center of an approximately square tunnel complex. A buffer zone 3.2 kilometers wide is established around the complex including the acquisition of mineral rights. As shown in Table 4.4l, individual burial sites are spaced on a 30-meter triangular lattice. Burial tunnels (drifts) are parallel to the 30-meter dimension, and five canisters are buried at each lattice position. There is one row of lattice positions in a burial tunnel. Preliminary calculations indicate that this triangular distribution limits granite and glass-ceramic waste temperatures to about $250^{\circ} \mathrm{C}$ and $400^{\circ} \mathrm{C}$, respectively. Both values are believed to be conservative but, as suggested in Section 4.6, are subject to change as the result of the Research and Development findings. Burial depth is 2.4 meters to the top of the top canister, and "pillar" width between burial tunnels is about 20 meters (based on mine heat loading considerations). During burial, tunnels are lined with "wire-mesh" for personnel protection from rock spalls. Burial tunnels are backfilled with crushed rock and sealed with a bulkhead when emplacement activities are completed in each tunnel. It is assumed that mining and burial can proceed simultaneously in separate main access tunnels.

Facility operations. The estimated operating staff requirements (except for security guards) are 11 supervisory and 23 nonsupervisory personnel on a 5-day week, one shift operation. The staff includes 4 supervisory and 10 nonsupervisory administrative personnel (including 5 security guards), 5 supervisory and 5 nonsupervisory engineering personnel, and 2 supervisory and 8 nonsupervisory operations personnel (cask/canister handling, burial, and mining (rews).

Solid Waste Emplaced in Mined Cavities - Interim Liquid Cooling and Conversion to Rock-Waste Matrix (Concept 2)

This concept is based on the random placement of waste canisters into a lined cavity located in any of several different geologic formations. For costing purposes, the cavity is located at a depth of 1,500 meters in a granite formation whose top extends to or near the surface. Structures and equipment are needed to receive and handle canisters shipped by rail in shielded shipping casks. The canisters are unloaded one at a time in hot cells and moved to the canister insertion room via crane. The crane cable will be used to lower the canisters into the mined cavity. 
Surface components will include the receiving facility, the canister insertion room, a well-head room for piping, and the condensers and water recycle equipment.

Water-bearing surface formations will be sealed by setting and cementing a 1.4-meter inside diameter (nominal) casing in a 2.3 meter drilled hole. The volume of the concrete and steel lined cavity will be 13,000 cubic meters.

0 ther information for capital and operating cost estimating is detailed in Table 4.42 .

Solid Waste Emplaced in Manmade Structures in Geologic Formations - Interim Air Cooling (Concept 3)

The economic incentive for artificial heat removal from buried waste lies in the reduced amount of mining required compared to a disposal concept which relies solely on conduction through the surrounding rock for removal of radioactive decay heat. The criterion used for sizing the facility is simply that the heat generation rate of the waste, at the end of the design lifetime of the cooling system, should be no greater than the rate at which heat can be conducted away from the waste through the surrounding rock without the waste containers or the surrounding rock reaching excessive temperatures. Therefore, at that time, the penetrations to the disposal area can be sealed.

To estimate the amount of mining required to hold the reference inventory of 14,500 canisters, it was assumed that: 1) The design lifetime of the cooling system is 100 years. 2) The permissible gross heat loading based on the surface area of the disposal site is $18.5 \mathrm{~W} / \mathrm{m}^{2}$ for the waste when it is 110 years 01d. This is roughly one-half the permissible heat loading of $33.6 \mathrm{~W} / \mathrm{m}^{2}$ est mated for 100-year-old waste from heat conduction calculations for the

Lyons, Kansas, disposal site. $(169)$ 3) The waste is 10 years old when buried so that the initial gross heat loading is $184.1 \mathrm{~W} / \mathrm{m}^{2}$. 4) All of the decay heat is to be removed by the cooling system. 5) The heat generation rate per canister is $3.39 \mathrm{kilowatts}$ at burial and decays to about 0.32 kilowatts 100 years after burial. 6) The burial depth is 600 meters.

The natural convection cooling systems are sized to remove the initial heat generation rate of 3.39 kilowatts per container. The cooling equipment reliability decreases with time, but so does the heat generation rate of the waste, so that a cooling unit can service more canisters in case some cooling units fail as they age. The facility requirements for this concept are listed in Table 4.43 .

Solid Waste Emplaced in Manmade Structures in Geologic Formations - Interim Water Cooling (Concept 4)

The economic incentive for artificial heat removal from buried waste lies in the reduced amount of mining required compared to a disposal concept which relies solely on conduction through the surrounding rock for removal of radioactive decay heat. The criterion used for sizing the facility is simply that 
TABLE 4.42. Facility Details for Cost Estimating Solid Waste Emplaced in Mined Cavities Interim Liquid Cooling and Conversion to Rock-Waste Matrix

\section{Overall Facility Description}

Concrete block/steel room construction

- Rail car airlock: $(45 \times 6) \times 14$ meters high

- Offices, laboratories: $(30 \times 12) \times 4.5$ meters high

- Maintenance/storage facility: $(30 \times 15) \times 14$ meters high

- Cask transfer gallery: $(15 \times 9) \times 7.5$ meters high

- Total area: $1250 \mathrm{~m}^{2}$

Hot Cells

- Shielding is 1.2 meters thick high-density concrete

- Transfer ce11: $(15 \times 15) \times 12$ meters high

- Condenser cell: $(15 \times 6) \times 12$ meters high

- Cable drum cel1: $(6 \times 15) \times 6$ meters high

- Total area: $420 \mathrm{~m}^{2}$

Drilled Holes

- Drill a 2.3 meter diameter hole 1520 meters deep

- Casing OD: $1.4 \mathrm{~m}$ (nominal) $\times 1.9 \mathrm{~cm}$ wall by 1520 meters

Three $0.6 \mathrm{~m}$ (nomina 1 ) $\times 1.3 \mathrm{~cm}$ wall by 1520 meters

- Mined Cavity: 13,000 $\mathrm{m}^{3}$ 1ined with concrete and stee 1

- Gross area: 16,000 $\mathrm{m}^{2}$ plus $3.2 \mathrm{~km}$ wide buffer zone

\section{Major Equipment}

$100 / 15$ ton bridge crane

one remotely controlled in-cell crane for in-cell transfer

One large cable drum

Eight viewing windows and pairs of manipulators

Two condensers of 20 megawatts capacity each (includes $100 \%$ redundancy)

40 megawatts of secondary air or water cooling capability (includes $100 \%$ redundancy)

Operating Data

Staff: 1 supervisory, 23 nonsupervisory

- Administration: 4 supervisory, 10 nonsupervisory (including 5 security guards)

- Engineering: 5 supervisory, 5 nonsupervisory

- Operations: 2 supervisory, 8 nonsupervisory

- 7 day week, 3 shifts 
TABLE 4.43. Facility Details for Cost Estimating -

Solid Waste Emplaced in Manmade Structures

in Geologic Formations - Interim Air Cooling

\section{Overall Facility Description}

Incoming Waste Handling Facilities

- Rail car air lock: $45 \times 6 \times 14$ meters

- Hoist House: $9 \times 9 \times 6$ meters

- Ventilation equipment: $12 \times 12 \times 5$ meters

- Offices and laboratories: $30 \times 12 \times 5$ meters

- Hot cell transfer gallery: $15 \times 7.6 \times 7.6$ meters

- Transfer cell: $15 \times 15 \times 6$ meters

- Working level cell: $15 \times 15 \times 6$ meters

- Shielding for hot cells: 1.2 meters of high-density

- Underground transporter concrete

Shafts

- Waste transfer shaft: 0.6 meter diameter (concrete

- and steel 1 ined)

- Personnel ventilation shaft: 1.8 meter diameter

- Personnel shaft: 1.8 meter diameter (steel and concrete 1 ined)

Disposal Tunnels

- Tunnel diameter: 9 meters

- Rock bolts: $2.5 \mathrm{~cm}-d i a m e t e r$ bolts, 3 meters long on

- Lining: $18 \mathrm{~cm}$.-thick shotcrete

- Tunnel arrangement: Parallel spacing 45.7 meters

- center to center

- Canister spacing: 1 canister per 0.387 linear meter

- of storage tunnel

- Total length of storage tunnel: $5.5 \mathrm{kilometers}$

- Disposal area exclusive of safety zone: $0.25 \mathrm{~km}^{2}$

- Safety zone: 3.2 kilometer minimum distance from

- Total site area: Approximately $50 \mathrm{~km} 2$

\section{Cooling Facilities}

- Total number of individual systems: 20

- Total number of cooling shafts: 40

- Shaft diameter: 2.1 meters (the shaft will be cased, rock bolted and/or shotcreted, depending on rock properties.)

- Total high efficiency filter area: 370 square meters

- Total medium efficiency filter area: 370 square meters

- Total heat removal duty for 20 systems: 50 megawatts

- Total cooling air flow for 20 systems: 3,000,000 kg/hr

- Cooling air exit temperature: $90^{\circ} \mathrm{C}$

Operating Data

Staff: 14 supervisory, 33 nonsupervisory

- Administration: 4 supervisory plus 8 nonsupervisory

- Engineering: 5 (including 5 security guards)

- Operations and maintenance: 5 supervisory, 20 nonsupervisory

operation: 5 day week, 1 shift except for security guards 
the heat generation rate of the waste, at the end of the design lifetime of the cooling system, should be no greater than the rate at which heat can be conducted away from the waste through the surrounding rock without the waste containers or the surrounding rock reaching excessive temperatures. Therefore, at that time, the penetrations to the disposal area can be sealed.

To estimate the amount of mining required to hold the reference inventory of 14,500 canisters, it was assumed that (1) the design lifetime of the cooling system is 100 years, (2) the permissible gross heating load based on the surface area of the disposal site is $18.5 \mathrm{~W} / \mathrm{m}^{2}$ for the waste when it is 110 years old. (This is roughly one-half the permissible heat loading of $33.6 \mathrm{~W} / \mathrm{m}^{2}$ estimated for 100-year-0ld waste from heat conduction calculations for the Lyons, Kansas site), (169) (3) the waste is 10 years $01 d$ when buried so that the initial gross heat load is $184.1 \mathrm{~W} / \mathrm{m}^{2}$. (4) All of the decay heat is to be removed by the cooling system. (5) The heat generation rate per canister is 3.39 kilowatts at burial and decays to about 0.32 kilowatts one hundred years after burial. (6) The burial depth is 600 meters.

The amount, size and kind of additional equipment and labor required are shown in Table 4.44 for the boiling water cooling. The cooling systems are sized to remove the initial heat generation rate of 3.39 kilowatts per container. The heat generation rate of the waste decreases with time thus reducing the cooling system heat removal load. A reduction in the heat load permits placing certain of the cooling units in a standby status for use in case failure of some of the operating units is experienced.

Boiling Water cooled Storage. Waste canisters remain within the repository after water cooling is terminated. They are initially spaced to produce an allowable heat loading of $18.5 \mathrm{~W} / \mathrm{m}^{2}$ after 100 years which should allow heat to be dissipated through the host rock without canister wall temperatures exceeding $300^{\circ} \mathrm{C}$. Heat is transferred to the surface by steam.

Liquid Waste Emplaced in a Mined Cavity - In-Place Drying and Conversion to Rock-Waste Matrix (Concept 5)

The concept is based on the placement of liquid waste into a mined cavity which is lined and located in any of several different geologic formations. For costing purposes, the cavity depth is taken to be 1500 meters in a granite formation whose top extends to or near the surface. The waste is piped from an on-site fuel processing plant.

Surface components include the hot cell where the condensers are located, the condenser operating area, and equipment for gas treatment before the gas is returned to the reprocessing plant.

Water-bearing surface formations are sealed by setting and cementing a 1.4 meter inside diameter (nominal) casing in a 2.3 meter drilled hole. The cavity has a volume of about 4000 cubic meters and has a concrete and stainlesssteel liner.

other information for capital and operating cost estimating is detailed in Table 4.45 . 


$$
\text { 4.F.9 }
$$

TABLE 4.45. Facility Details for Cost Estimating Liquid Waste Emplaced in a Mined Cavity In-Place Drying and Conversion to Rock-Waste Matrix

\section{Overall Facility Description}

Concrete block/steel room construction

- Offices, Laboratories: $(30 \times 12) \times 4.6 \mathrm{~m}$ high

- Maintenance/storage facility: $(30 \times 15) \times 6 \mathrm{~m}$ high

- Total area: $84 \mathrm{~m}^{2}$

Hot Cells

- Shielding is $1.2 \mathrm{~m}$ thick high-density concrete

- Condenser and well-head room $(6 \times 6)$ by $6 \mathrm{~m} \mathrm{high}$

- Partial cell for feed tank $(3 \times 3)$ by $6 \mathrm{~m} \mathrm{high}$

- Total area: $50 \mathrm{~m}^{2}$

Drilled Hole

- Drilla 2.3 m diameter hole 1500 meters deep

- Stainless-steel lined casing: one $1.4 \mathrm{~m}$ OD (nominal) $\times 1.9 \mathrm{~cm}$ wall by $1525 \mathrm{~m}$ three $0.6 \mathrm{~m}$ OD (nominal) $\times 1.3 \mathrm{~cm}$

- Mined cavity, $4300 \mathrm{~m}^{3}$ lined with concrete and stainless steel Gross area: $16,000 \mathrm{~m}^{2}$ plus $3.2 \mathrm{~km}$ wide buffer zone around site or approximately 40 square kilometers

\section{Major Equipment}

Two condensers of 80 megawatt capacity each

Process gas and liquid piping to reprocess plant

3800 liter temporary waste holdup tank

\section{Operating Data}

Staff: (Incremental above that of reprocessing plant needs) 5 supervisory, 14 nonsupervisory

- Administration: 2 supervisory, 7 nonsupervisory (including 5 security guards)

- Engineering: 2 supervisory, 2 nonsupervisory

- Operations: 1 supervisory, 5 nonsupervisory

Operation: 7 day week, 3 shifts 
4.F.10

Liquid Waste Emplaced in Exploded Cavities - In-Place Drying and Conversion to Rock-Waste Matrix (Concept 6)

The concept is based on the placement of liquid waste into an exploded cavity located in any of several different geologic formations. For costing purposes, the cavity is formed at a depth of 1500 meters in a granite formation whose top extends to or near the surface. The waste is piped from an on-site fuel processing plant.

Surface components include the hot cell where the condensers are located, the condenser operating area, and equipment for gas treatment before it is returned to the reprocessing plant.

Water-bearing surface formations are sealed off by setting and cementing a 1.4 meter inside diameter (nominal) casing in a $2.3 \mathrm{~m}$ drilled hole. The cavity is generated by a 5 kiloton nuclear explosion at hole bottom and is not lined. other information for capital and operating cost estimating is detailed in Table 4.46 .

Solid Waste Emplaced in a Matrix of Drilled Holes - No Melting (Concept 7 )

This concept is based on the placement of waste canisters in drilled holes in a thick granite formation, the top of which is located at a depth of approximately 3000 meters. It is overlain by medium-hard sedimentary rocks. Structures and equipment are needed to receive and handle canisters shipped in shielded casks. Canisters are unloaded one at a time in hot cells and then placed in a shielded, self-propelled charging vehicle. The vehicle transports the canisters to the disposal area (via a rail network) and lowers the canister into a previously drilled hole.

Surface components include the receiving facility, a storage and maintenance facility for the charging vehicle and drill rigs, and surge "mud" storage space.

Water bearing surface formations are sealed by setting and cementing a 38 centimeter inside diameter (nominal) casing in a drilled hole that accepts the casing. The casing extends the full length of each hole which is 4500 meters deep. Each hole contains 300 canisters in the bottom 1200 meters of the drill hole. After 300 canisters have been added to a hole, the top 3300 meters of the hole is sealed with alternating plugs of clay and cement sealants. One hole is drilled for each 4 hectares of 1 and, and a total of 49 holes is needed.

0 the $r$ information for capital and operating cost estimating is detailed in Table 4.47 .

Solid Waste Emplaced in a Deep Hole - In-Place Conversion to a Rock-Waste Matrix (Concept 8 )

The concept is based on the placement of waste canisters into deep holes drilled into any of several different geologic formations. For costing purposes, the reference stratigraphy used is $3 \mathrm{kilo}$ meters of sedimentary rock overlaying a very thick (greater than 13 kilometers) granite formation. The hole depth is to be 16 kilometers. Structures and equipment are needed to 
TABLE 4.46. Facility Details for Cost Estimating -

Liquid Waste Emplaced in Exploded Cavities In-Place Drying and Conversion to Rock-Waste

Matrix

\section{Overall Facility Description}

Concrete block/steel room construction

- Office, laboratories: $(30 \times 12) \times 4.6 \mathrm{~m} \mathrm{high}$

- Maintenance/storage facility: $(30 \times 15) \times 6 \mathrm{~m} \mathrm{high}$

- Total area: 1,000 $\mathrm{m}^{2}$

Hot Cells

- Shielding is $1.2 \mathrm{~m}$ thick high-density concrete

- Condenser room: $(30 \times 6) \times 6 \mathrm{~m} \mathrm{high}$

- Total area: $185 \mathrm{~m}^{2}$

Drilled Holes

- Drill a 2.3 m diameter hole $1500 \mathrm{~m}$ deep

- Stainless-steel lined casing:

One $1.4 \mathrm{~m} \mathrm{OD} \mathrm{(nominal)} \times 1.9 \mathrm{~cm}$ wall by $1525 \mathrm{~m}$

Three $0.6 \mathrm{~m}$ OD (nominal) $\times 1.3 \mathrm{~cm}$ wall by $1525 \mathrm{~m}$

- Exploded cavity free volume $4,300 \mathrm{~m}^{3}$

Gross area: $16,000 \mathrm{~m}^{2}$ plus $3.2 \mathrm{~km}$ wide buffer zone around site or approximately 40 square kilometers

\section{Major Equipment}

Two condensers of $80 \mathrm{MW}$ capacity each

Process gas and liquid piping to reprocessing plant

3800 liter temporary waste holdup tank

\section{Operating Data}

Staff: (incremental above that of reprocessing plant needs) 5 supervisory, 14 nonsupervisory

- Administration: 2 supervisory, 7 nonsupervisory (including equivalent of 5 security guards)

- Engineering: 2 supervisory, 2 nonsupervisory

- Operations: 1 supervisory, 5 nonsupervisory

operation: 7 day week, 3 shifts 


\section{F. 12}

TABLE 4.47. Facility Details for Cost Estimating -

Solid Waste Emplaced in a Matrix of

Drilled Holes - No Melting

\section{Overall Facility Description}

Concrete block/steel roof construction

- Rail car air lock: $(46 \times 6) \times 14 \mathrm{~m}$ high

- Offices, laboratories: $(30 \times 12) \times 4.6 \mathrm{~m} \mathrm{high}$

- Maintenance/storage facility: (30 x 15) x $14 \mathrm{~m} \mathrm{high}$

- Total area: 1,100 $\mathrm{m}^{2}$

Hot Cells

- Shielding is $1.2 \mathrm{~m}$ thick high-density concrete

- Transfer gallery: $(23 \times 9) \times 7.6 \mathrm{~m} \mathrm{high}$

- Total area: $210 \mathrm{~m}^{2}$

Drilled Holes

- Hole depth: 4,500 meters

- Casing 0D: 40.5 cm (nominal) x $1.3 \mathrm{~cm}$ wall

- Number required: 49

- Drilling and casing rate: $195 \mathrm{~m}$ per week, average

- "Lattice" spacing: square, $200 \mathrm{~m}$ on center

- Gross area: $2 \mathrm{~km}^{2}$ plus a $0.8 \mathrm{~km}$ wide buffer around site, or approximately $10 \mathrm{~km}^{2}$

- Equipped with sealed removable covers

\section{Major Equipment}

$100 / 15$ ton bridge crane

Drill rig

Charging vehicle and track layout; with shielded, 35 ton movable cask $(23 \mathrm{~cm}$ shielding, $38 \mathrm{~cm}$ bore, $3.7 \mathrm{~m}$ long), self powered unit that travels on rails, equipped with run and jog speeds, and lowering hoist. Instrumentation/power console to indicate vehicle position and cable tension and evaluation, capable of cooling canister if required and sealing drill hole when cover is open.

one rig to add clay and cement sealants to each hole when hole is filled. Rig must keep hole sealed while operating.

One remotely controlled in-cell crane for in-cell transfer

Eight viewing windows and pairs of manipulators

\section{Operating Data}

Staff: 11 supervisory, 23 nonsupervisory

- Administration: 4 supervisory, 10 nonsupervisory (including 5 security guards)

- Engineering: 5 supervisory, 5 nonsupervisory

- Operating: 2 supervisory, 8 nonsupervisory

operation: 5 day week, 1 shift except for security guards 


\section{F.13}

receive and handle canisters shipped by rail in shielded shipping casks. The canisters are unloaded one at a time in hot cells and transported to the hole in a shielded transporter. The vehicle is used to lower the canister into the previously drilled hole.

Surface components include the receiving facility, a storage and maintenance facility for the charging vehicle, a very large drill rig, and surge "mud" storage space.

The reference hole geometry and drilling steps are described as follows: Dri11 a 2.2 meter diameter hole to approximately 100 meters and set 1.5 meter inside diameter casing. Cement the casing to the surface. Drill a 0.8 meter hole to a depth of about 7.6 kilometers and set and cement a 0.5 meter outside diameter casing. Drill below the 0.5 meter casing with a 0.4 meter bit to the desired 16 kilometer total depth.

Each hole contains 2500 canisters in the bottom 7500 meters. One hole is drilled for each 0.4 square kilometer of 1 and, and a total of six holes are needed. The top 8500 meters of each hole is sealed with alternating plugs of clay and cement sealants when the hole is full.

other information for capital and operating cost estimating is detailed in Table 4.48 .

Liquid Waste Emplaced in a Deep Hole - In-Place Drying and Conversion to a Rock-Waste Matrix (Concept 9)

This concept is based on placement of liquid waste into deep holes drilled into any of several different geologic formations. For costing purposes, the reference stratigraphy used here is 3000 meters of sedimentary rock overlying very thick (greater than 13,000 meters) granite formation. The hole depth is 16,000 meters. The waste is piped into the hole from an on-site fuel processing plant.

Surface components include the hot cell where the condensers are located, the condenser operating area, equipment for gas treatment before it is returned to the reprocessing $p l a n t$, a storage and maintenance facility for the drill rigs, and surge "mud" storage space. One hot cell and associated equipment is used for each drill hole.

The reference hole geometry and drilling steps are described as follows: Drill a 2.2 meter diameter hole to approximately 110 meters and set 1.5 meter inside diameter casing. Cement the casing to the surface. Drill a 0.8 meter hole to a depth of about 7600 meters and set and cement a 0.5 meter outside diameter casing. The casing is lined with $3 \mathrm{millimeter}$ thick stainless steel. Drill below the 0.5 meter casing with a 0.4 meter bit to the desired 16,000 meter total depth.

For the reference 5 MT/day disposal site, each hole contains waste from 15,400 MT or 3100 days of operation in the bottom 7500 meters of the drilled hole. One hole is drilled for each 40,000 square meters of 1 and and a total of three holes is needed. 
TABLE 4.48. Facility Details for Cost Estimating -

Solid Waste Emplaced in a Deep Hole.

In-Place Conversion to a Rock-Waste

Matrix

\section{Overall Facility Description}

Concrete block-steel room construction (same as for drilled matrix holes)

- Rail car airlock: $(45 \times 6 \times 14$ meters

- Offices, labs: $(30 \times 12) \times 4.6$ meters

- Maintenance/storage facility: $(30 \times 15) \times 14$ meters

- Total area: $1100 \mathrm{~m}^{2}$

Hot Cells

- Shielding is 1.2 meter thick high-density concrete

- Can manipulating cells: $(23 \times 9) \times 7.6$ meters high

- Total area: $210 \mathrm{~m}^{2}$

Drilled Holes

- Casing 0D: 1.5 meter (nominal) x $1.3 \mathrm{~cm}$ wall to 107 meters depth

0.5 meter (nominal) $\times 2.5 \mathrm{~cm}$ wall to 7600 meters depth

- Drill hole: 0.4 meter diameter by 7600 meter at bottom

- Drilling rate: $69 \mathrm{~m}$ per week average

casing rate: $34 \mathrm{~m}$ per week average

- "Lattice" spacing: $637 \mathrm{~m}$ square pattern

- Gross area: $2.4 \mathrm{~km}^{2}$ plus 3.2 kilometer wide buffer zone around the site, or approximately 65 square kilometers

- Equipped with sealed removable covers (the same as for drilled matrix holes)

\section{Major Equipment}

$100 / 15$ ton bridge cranes

One drill rig - biggest yet built

Charging vehicle and track layout; with shielded, 35 ton movable cask ( $23 \mathrm{~cm}$ of shielding, $28 \mathrm{~cm}$ bore, $2.6 \mathrm{~cm}$ long), self-powered unit that travels on rails, equipped with run and jog speeds, and lowering hoist. Instrumentation/power console to indicate vehicle position and cable tension and elevation, capable of cooling canister if required and sealing drill hole when cover is open.

One rig to add clay and cement sealants to each hole when hole is filled. Rig must keep hole sealed while operating.

One remotely controlled in-cell crane for in-cell transfer

Eight viewing windows and pairs of manipulators

Operating Data

Staff: 11 supervisory, 25 nonsupervisory

- Administration: 4 supervisory, 10 nonsupervisory (including

5 security guards)

- Engineering: 5 supervisory, 5 nonsupervisory

- Operations: 2 supervisory, 10 nonsupervisory

operation: 5 day week, 1 shift except for security quards 


\section{F.1.5}

After filling, the top 8500 meters of each hole is sealed with alternating plugs of clay and cement sealants.

other information for capital and operating cost estimating is detailed in Table 4.49 .

Liquid Waste Emplaced by Hydraulic Fracturing - In-Place Conversion to a Solid (Concept 10)

Cost estimates are based on a reference system where the liquid high-level waste is mixed with dry solids such as cement to form a slurry which is subsequently injected into a well which has been fractured previously with water. The slurry is forced under pressure into the fracture and the pressure maintained until the slurry solidifies. The system consists of the surface facility, thirty injection wells, and sixty monitoring wells cased to 1000 meters. The remainder of the system consists of plant equipment such as storage tanks, mixer, pumps, well head, etc.

The waste is piped from an on-site fuel reprocessing plant to waste storage tanks, at an average rate of 19001 iters/day for 25 years for the reference five MT/day reprocessing rate. The waste is held for about five years of interim storage before injection. It is assumed that each injection will consist of 300,000 liters of a waste-cement slurry and that one well will receive about 18 million liters of waste.

The surface facility includes hot cells for mixing of dry solids and waste, an injection well head, equipment for offgas treatment waste and cement storage facility, and miscellaneous plant equipment.

The reference well is a 15 centimeter diameter cased and cemented hole by 1000 meters deep. The casing is 1.3 centimeter thick stainless steel. After the well is filled completely, it is sealed with mixtures of cements and sealants.

other information for capital and operating cost estimating is presented in Table 4.50 . 
4.F. 16

TABLE 4.49. Facility Details for Cost Estimating Liquid Waste Emplaced in a Deep Hole In-Place Drying and Conversion to a Rock-Waste Matrix

\section{Overall Facility Description}

Concrete block/steel room construction

- Office, 1abs: $(30 \times 12) \times 4.6 \mathrm{~m} \mathrm{high}$

- Maintenance/storage facility: $(30 \times 15) \times 14 \mathrm{~m} \mathrm{high}$

- Total area: $870 \mathrm{~m}^{2}$

Hot Cells

- Shielding is $1.2 \mathrm{~m}$ thick high-density concrete

- Condenser and we11-head room: $(6 \times 6) \times 6 \mathrm{~m} \mathrm{high}$

- Partial cell for feed tank: $(3 \times 3) \times 6 \mathrm{~m} \mathrm{high}$

- Total area: $46 \mathrm{~m}^{2}$

Drilled Holes

- Stainless-steel lined casing:

$1.5 \mathrm{~m} \mathrm{OD} \mathrm{(nominal)} \times 1.3 \mathrm{~cm}$ wall by $107 \mathrm{~m}$

$0.5 \mathrm{~m} \mathrm{OD} \mathrm{(nominal)} \times 2.5 \mathrm{~cm}$ wall by $7600 \mathrm{~m}$

- Drill hole: $0.4 \mathrm{~m}$ diameter $\times 2600 \mathrm{~m}$ at bottom

- Number required: three

- Drilling rate: $34 \mathrm{~m}$ per week average

- Casing rate: 19 m per week average

- "Lattice" spacing: 200 m square pattern

- Gross area: $0.1 \mathrm{~km}^{2}$ plus $3.2 \mathrm{kilometers}$ wide buffer zone around site, or approximately $45 \mathrm{~km}^{2}$

\section{Major Equipment}

Two condensers of 10 megawatt cooling capacity each

Drill rig - biggest yet built

Process gas and liquid piping to reprocessing plant

4000 liter temporary waste hold-up tank

one rig to add clay and cement sealants to each hole when hole is

filled. Rig must keep hole sealed while operating

\section{Operating Data}

Staff: (incremental above that of reprocessing plant needs)

5 supervisory, 14 nonsupervisory

- Administration: 2 supervisory, 7 nonsupervisory (including

$$
5 \text { security guards) }
$$

- Engineering: 2 supervisory, 2 nonsupervisory

- Operations: 1 supervisory, 5 nonsupervisory

Operation: 7 day week, 3 shift 
TABLE 4.50. Facility Details for Cost Estimating Liquid Waste Emplaced by Hydrautic

Fracturing - In-Place Conversion to a Solid

\section{Overall Facility Description}

Concrete $b$ lock/stee 1 room construction

- Office, labs: $(30 \times 12) \times 5 \mathrm{~m} \mathrm{high}$

- Maintenance/storage facility: $(30 \times 15) \times 6 \mathrm{~m} \mathrm{high}$

- Total area: 810 square meters

Hot Celis

- Shielding is 1.2-m thick high-density concrete

- Mixer ce1t, injection ce $11(6 \times 6)$ by $6-\mathrm{m}$. high

- Feed Tank and Waste Pump CeTr $(6 \times 6)$ by 6-m high

- Total area: $108 \mathrm{~m}^{2}$

Drilled Holes

- Stainless-steel lined casing:

1-15 cm OD (nominal) $\times 1.3 \mathrm{~cm}$ wall by $1000 \mathrm{~m}$

$4-5 \mathrm{~cm}$ OD (nominal) $\times 1.3 \mathrm{~cm}$ wall by $1000 \mathrm{~m}$

- Drill hole: 1-15 cm diameter $\times 1000 \mathrm{~m}$ at bottom

$4-5 \mathrm{~cm}$ diameter $\times 1000 \mathrm{~m}$ at bottom

- Gross Area: $65 \mathrm{~km}^{2}$ plus a $3.2 \mathrm{~km}$ wide buffer zone around the site, or approximately $200 \mathrm{~km}^{2}$

\section{Operating Data}

Staff: (incremental above that of reprocessing plant needs)

5 supervisory, 14 nonsupervisory

- Administration: 2 supervisory, 7 nonsupervisory (including 5 security guards)

- Engineering: 2 supervisory, 2 nonsupervisory

- Operations: 1 supervisory, 5 nonsupervisory

Operation: 7 day week, 3 shift 


\section{$+$ .}

- 
BNWL -1900

APPENDIX $4 . G$

TIMING REQUIREMENTS FOR RESEARCH AND DEVELOPMENT NEEDS

AND BENEFICIAL OCCUPANCY OF A COMMERCIAL REPOSITORY 


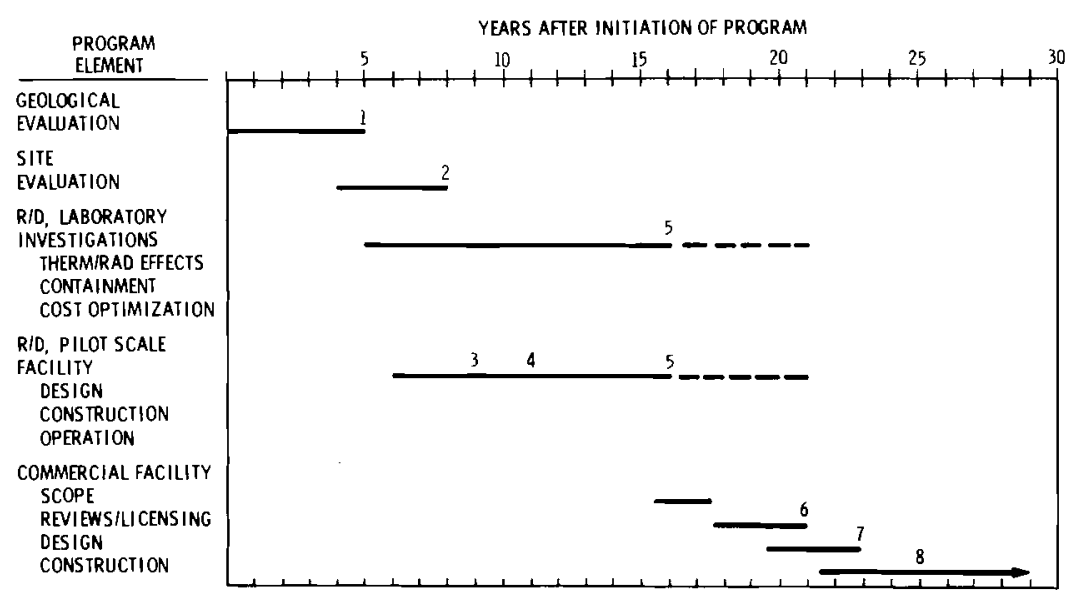

MILESTONES

1. SITE SELECTED

2. SITE EVALUATION COMPLETE AND SITE ACCEPTED FOR PILOT SCALE DEMONSTRATION

3. PILOT-SCALE FACILITY DESIGN COMPLEEE

4. PILOT-SCALE FACILITY CONSTRUCTION COMPLETE, BEGIN OPERATION

5. DECISION TO PROCEED WITH COMMERCIAL FACILITY BASED ON R\&D PROGRAM:

6. CONSTRUCTION PERMI
7. DESIGN COMPLTE

8. BENEFICIAL OCCUPANCY

FIGURE 4.G.1. R\&D Program Leading to Establishment of a Commercial Facility, Solid Waste Emplacement in a Mined Cavity - No Fluid Cooling or Melting

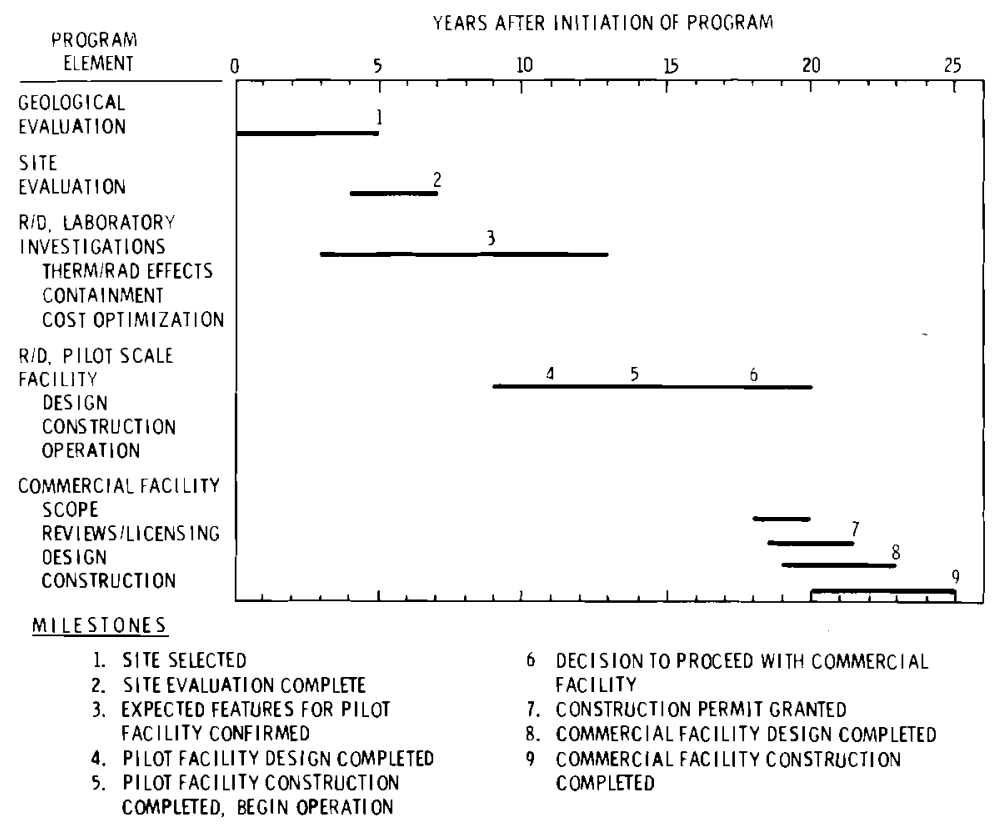

FIGURE 4.G.2. R\&D Program Leading to Establishment of a Commercial Facility, Solid Waste Emplacement in a Mined Cavity Interim Liquid Cooling and Waste-Rock Melting 

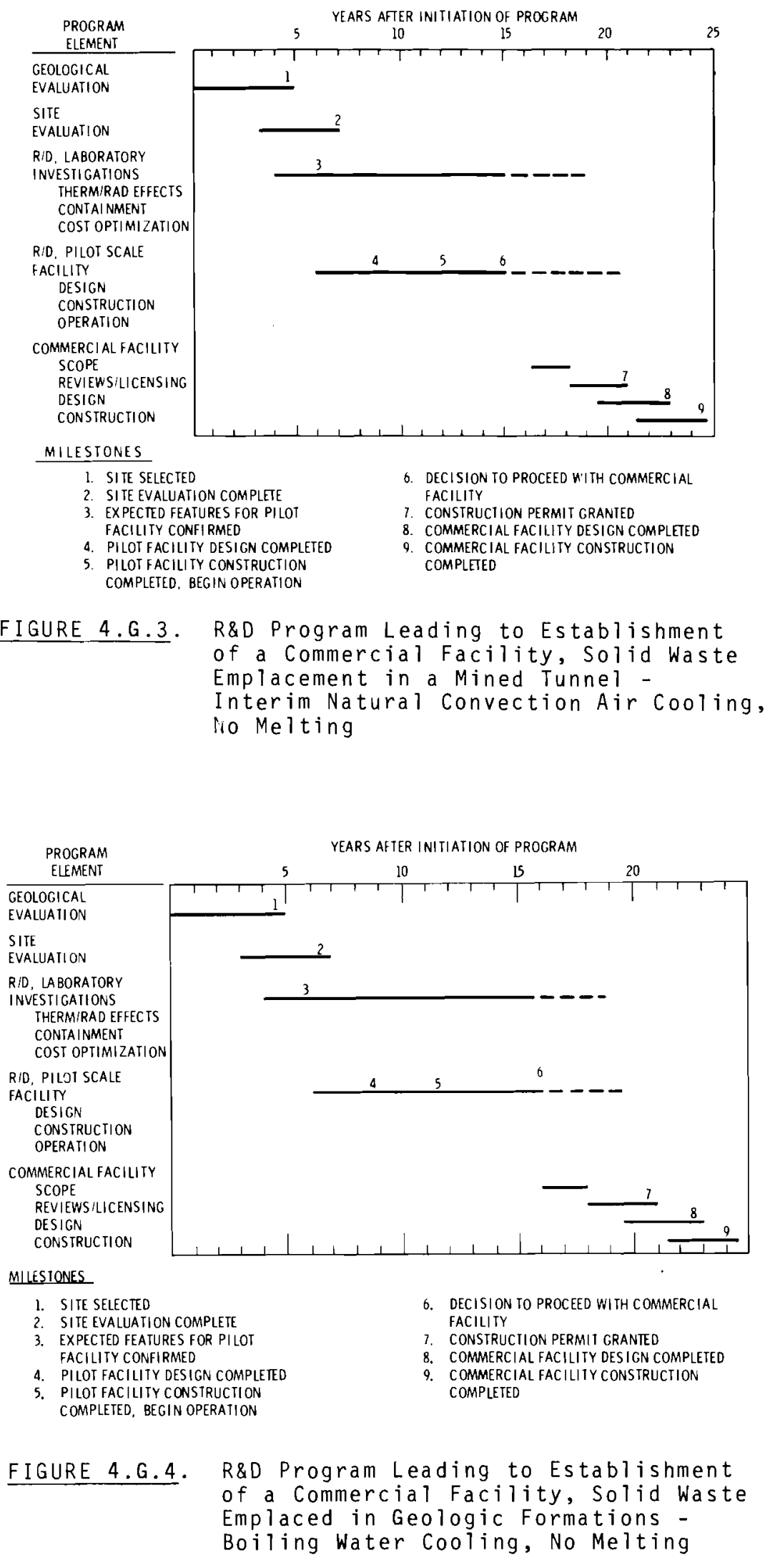

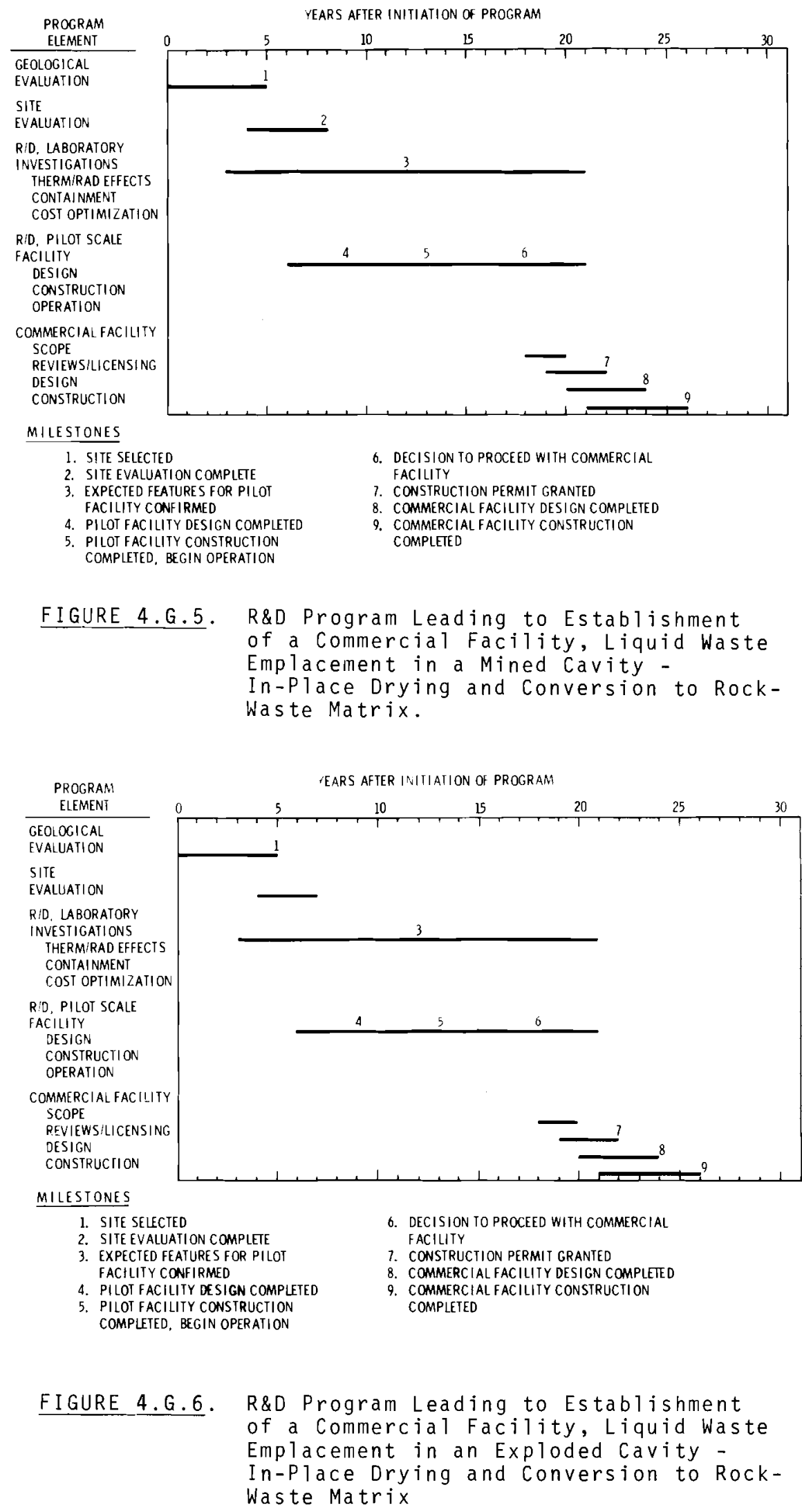

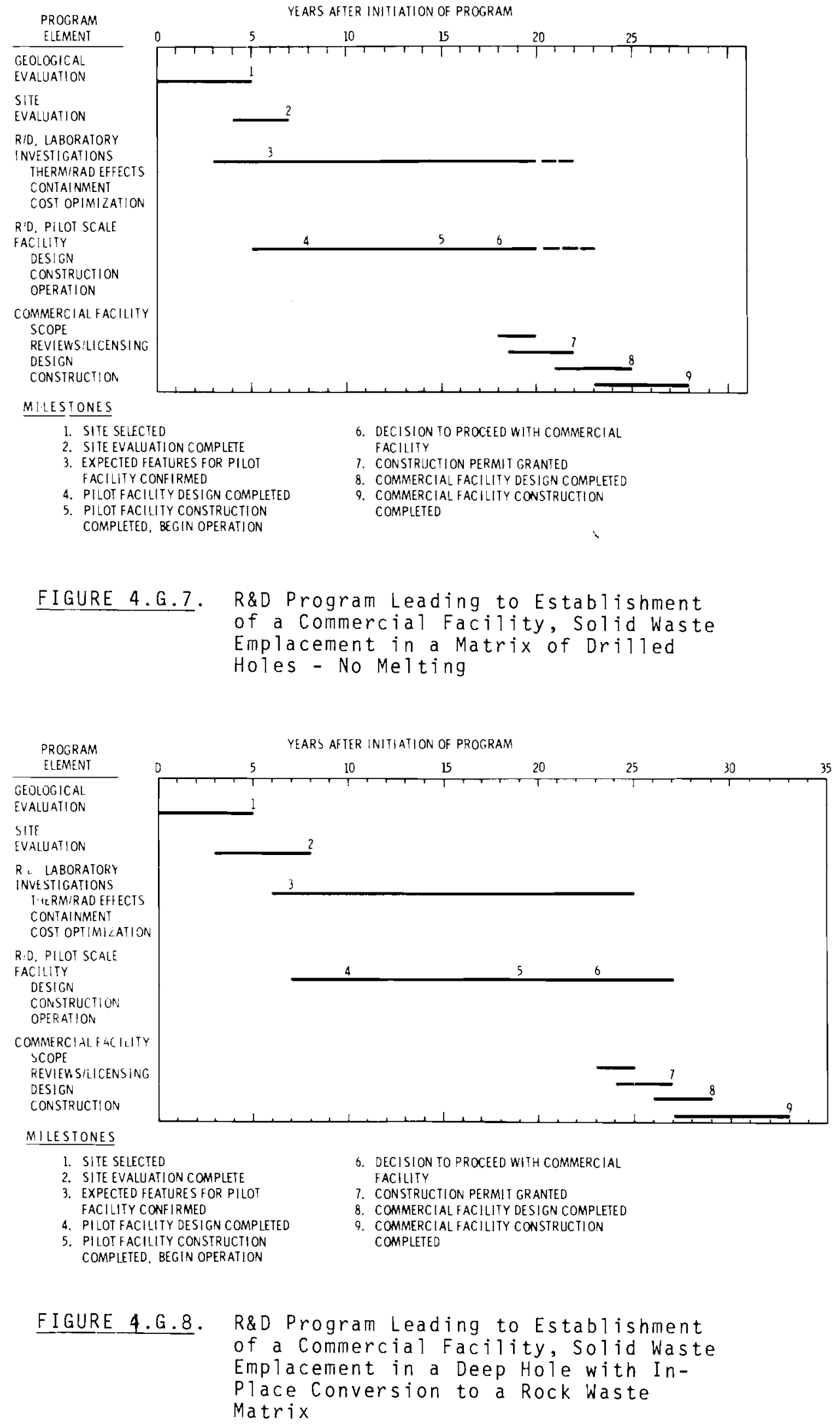

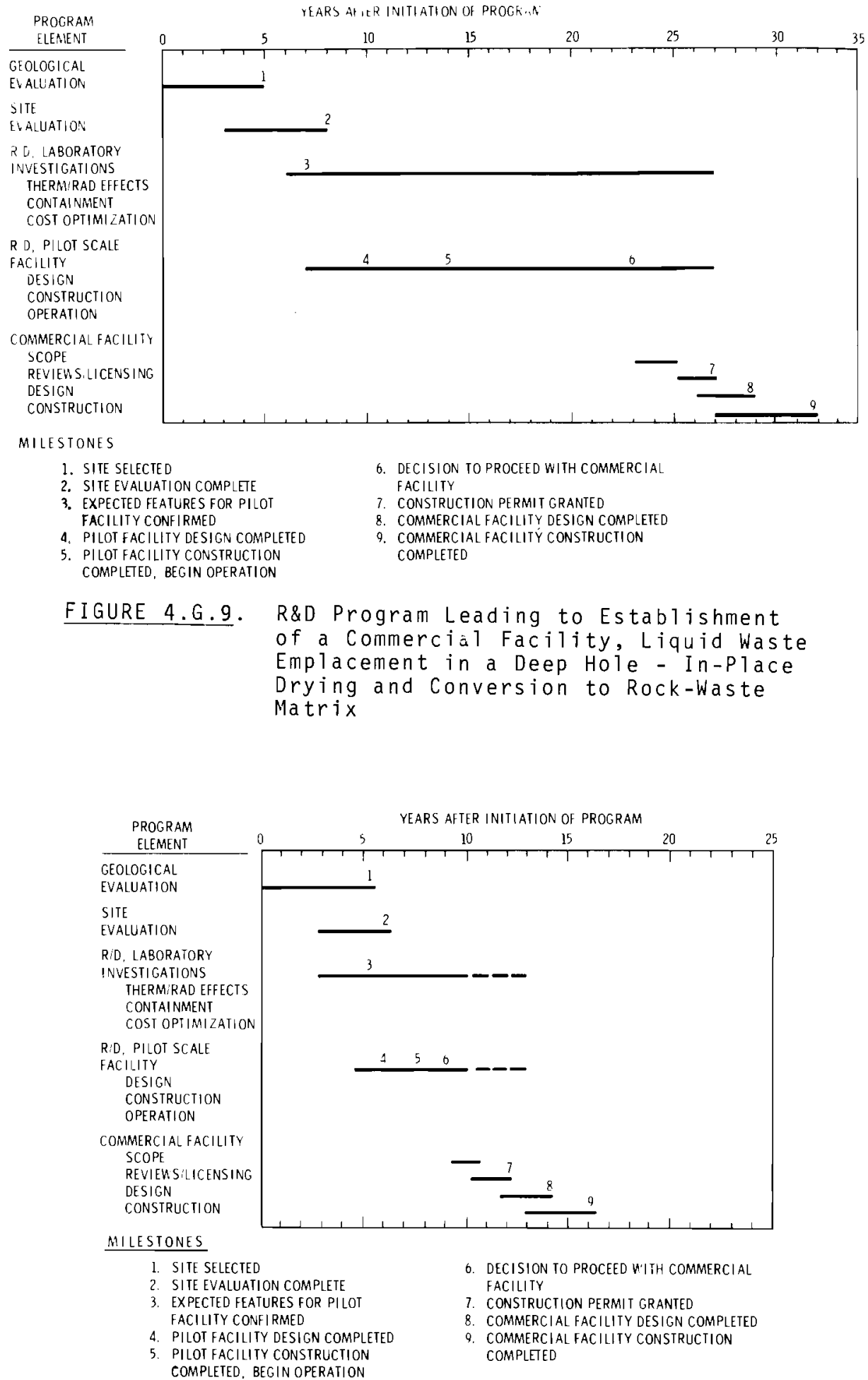

FIGURE 4.G.10. R\&D Program Leading to Establishment of a Commercial Facility, Liquid Waste Emplacement by Hydraulic Fracturing In-Place Conversion to a Solid 


\section{DISTRIBUTION}

No. of

Copies

OFFS I TE

1 AEC Chicago Patent Group

9800 South Cass Avenue

Argonne, IL 60439

4 U.S. Atomic Energy Commission Headquarters

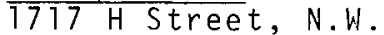

Washington, DC 20545

Public Reading Room

2 U.S. Atomic Energy Commission Advisory Committee on Reactor Safeguards

Washington, DC 20545

H. G. Mangelsdorf

Executive Secretary

50 U.S. Atomic Energy Commission Division of Waste Management and Transportation, Hdatrs. Washington, DC 20545

$$
\text { F. K. Pittman }
$$

$1 \quad$ U.S. Atomic Energy Commission Office of Regulation Washington, DC 20545

1 U.S. Atomic Energy Commission Albuquerque Operations

P.0. Box 5400

A 1buquerque, NM 87115

1 U.S. Atomic Energy Commission Chicago Operations office

9800 South Cass Avenue

Argonne, IL 60439

1 U.S. Atomic Energy Commission Idaho Operations

550 2nd street

Idaho Falls, ID 83401

Public Reading Room

1 U.S. Atomic Energy Commission Nevada Operations

P.0. Box 14700

Las Vegas, NV 98114

Reports Control Clerk
No. of

Copies

3 U.S. Atomic Energy Commission

Oak Ridge operations

P.0. Box 62

Oak Ridge, TN 37830

Manager

Technical Information Center (2)

2 U.S. Atomic Energy Commission

San Francisco operations

T333 Broadway

oakland, CA 94612

Information Services

Public Reading Room

2 U.S. Atomic Energy Commission Savannah River Operations P.0. Box A

Aiken, SC 29801

Manager

Public Reading Room

1 U.S. Mission to European

Community - Brussels

c/o American Embassy

APO NY 09667

Julis $H$. Rubin

1 U.S. Atomic Energy Commission

Scientific Representative

U.S. Embassy - Tokyo

APO San Francisco 96503

1 Allied Chemical Company 550-2nd Street

Idaho Falls, ID 83401

Technical Files

1 Argonne National Laboratory 9700 South Cass Avenue Argonne, IL 60439

1 U.S. Army

P.0. Box 282

Hanover, NH 03755

Cold Regions Research and Engineering Laboratory 
No. of

Copies

1 Brookhaven National Laboratory Upton, NY TT973

1 E.I. duPont de Nemours \& Co. Savannah River Laboratory Aiken, SC 29801

Library

1 Environmental Protection Agency Headquarters

401 M street, S.W.

Washington, DC 20460

i U.S. Geological Survey

Denver Federat Center, B1dg. 25

Denver, C0 80225

W. S. Twenhofel

1 U.S. Geologica i Survey Washington: DC 20242

G. D. DeBuchanarine

1 Library of Congress

Exchange \& Gifi Jivision

10 First sireet, S.E.

Washiriton, DC 20540

1 Los Alamos Scientific

Laborstiry

P. O. $00 x 1663$

iss Alamos, NM 87544

1 Mational Academy of Sciences

itional Research Council

öTision of Earth Sciences

2101 Constitution Avenue, N.W.

Washington, DC 20418

1 National Acronautics \& Space

Lewis pesearch Center

21000 Brookpark Road

Cleveland, $\mathrm{OH} 44135$

Dorothy Morris

1 National Aeronautics \& Space Administration USS 10

Washington, DC 20546

Document Control officer

1 National Bureau of Standards Administration BTdg. Rooni E-01 Washington, DC 20234

Library
No. of

Copies

100 National Technical Information Service

U.S. Dept. of Commerce

5285 Port Royal Road

Springfield, VA 22151

$1 \quad$ Naval Civil Engineering

Laboratory

U.S. Navy

Port Hueneme, CA 93043

1 Dak Ridge National Laboratory Nuclear Division

P.0. BOX X

Oak Ridge, TN 37830

Library

1 Sandia Laboratories

A 1 buquerque 0perations office

ATbuquerque, NM 87775

Library

1 Southern Interstate Nuclear Board

7 Dunwoody Park, Suite 104

Atlanta, GA 30341

J. T. Goodwin

1 University of California Lawrence Livermore Laboratory

P.0. Box 808

Livermore, CA 94550

Technical Information Dept.

1 Washington state

Office of Nuclear Energy

Development

Genera $1 \overline{A d m}$ inistration

01 ympia, WA 98502

L. Bradley

1 Western Interstate Nuclear Board

P.O. Box 15038

Lakewood, CO 80215

92 State University Libraries

50 State Capital Libraries

57 Major City Libraries 
No. of

Copies

ONS ITE - HANFORD

17 U.S. Atomic Energy Commission Richland, Operations

P.0.Box 550

Richland, WA 99352

R. B. Goranson (15)

Technical Information

Library (2)

2 Atlantic Richfield Hanford

Company

P.0. Box 250, Federal B1dg.

Richland, WA 99352

J. H. Warren/H. P. Shaw

Technical Files

1 Douglas United Nuclear, Inc. P.O. Box 490

Richland, WA 99352

DUN File
No. of

Copies

1 Westinghouse Hanford Company Hanford Engineering Development Laboratory

P.O. Box 1970

Richland, WA 99352

1 ! Batte? Ie-Northwest

N. E. Carter/R. C. Liikala

$\therefore$ C. Fox/D. E. Deonigi

M. R. kreiter/G. A. Jansen

H. E. Nightingale/R. E. Burns

D. E. Oleser.'R. W. Wa Ilace

A. M. P?at

L. C. Schmid/K. Drumbeller

K. j. Echreider

C. M. unruh/J. P. Corley

Technical Information (2) 
Kentucky State College

Library

Frankfort, KY 40601

Louisiana State University

Library

Alexandria, LA 71301

Louisiana State University

Library

Baton Rouge, LA 70803

University of Maine

Library

Augusta, ME 04330

University of Maine

Library

orono, ME 04473

University of Maryland

Library

College Park, MD 20742

University of Boston

Campus Library

Boston, MA 02116

University of Michigan

Library

Ann Arbor, MI 48104

Michigan State University

Library

East Lansing, MI 48823

University of Minnesota

Library

Minneapolis, MN 55455

University of Mississippi

Library

University, MS 38677

Mississippi State University

Library

State College, MS 39762

University of Missouri

Library

Columbia, MO 65201

University of Missouri

Library

Kansas City, KS 64110

University of Montana

Library

Missoula, MT 59801

\author{
Montana State University \\ Library \\ Bozeman, MT 59715 \\ University of Nebraska \\ Library \\ Lincoln, NB 68508 \\ University of Nebraska \\ Library \\ Omaha, NB 68101 \\ University of Nevada \\ Library \\ Las Vegas, NV 89109 \\ University of Nevada \\ Library \\ Reno, NV 89507 \\ University of New Hampshire \\ Durham, NH 03824 \\ The State University \\ Rutgers Library \\ New Brunswick, NJ 08903 \\ Newark State College \\ Library \\ Union, NJ 07083 \\ University of New Mexico \\ Library \\ Albuquerque, NM 87106 \\ New Mexico State University \\ Library \\ Las Cruces, NM 88001 \\ New York University \\ Library \\ New York, NY 10003 \\ New York State University \\ Library \\ Buffalo, NY 14214 \\ University of North Carolina \\ Library \\ Chapel Hil1, NC 27514 \\ University of North Carolina \\ Library \\ Raleigh, NC 27607 \\ University of North Dakota \\ Library \\ Grand Forks, ND 58201 \\ North Dakota State School of \\ Science Library \\ Wahpeton, ND 58075
}




\section{STATE UNIVERSITY LIBRARIES}

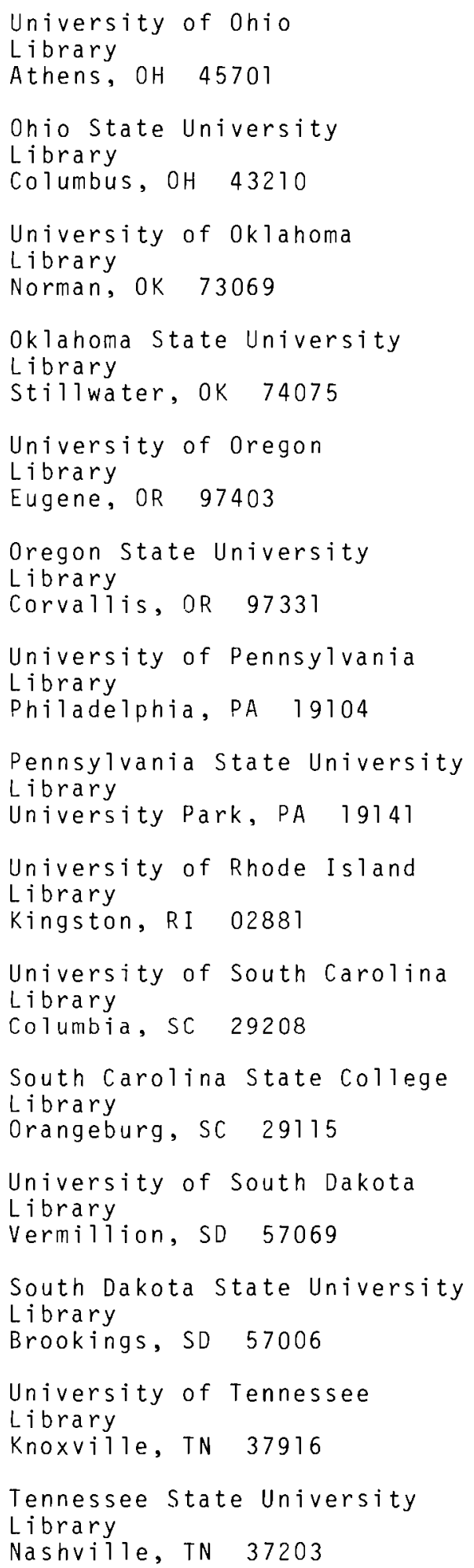

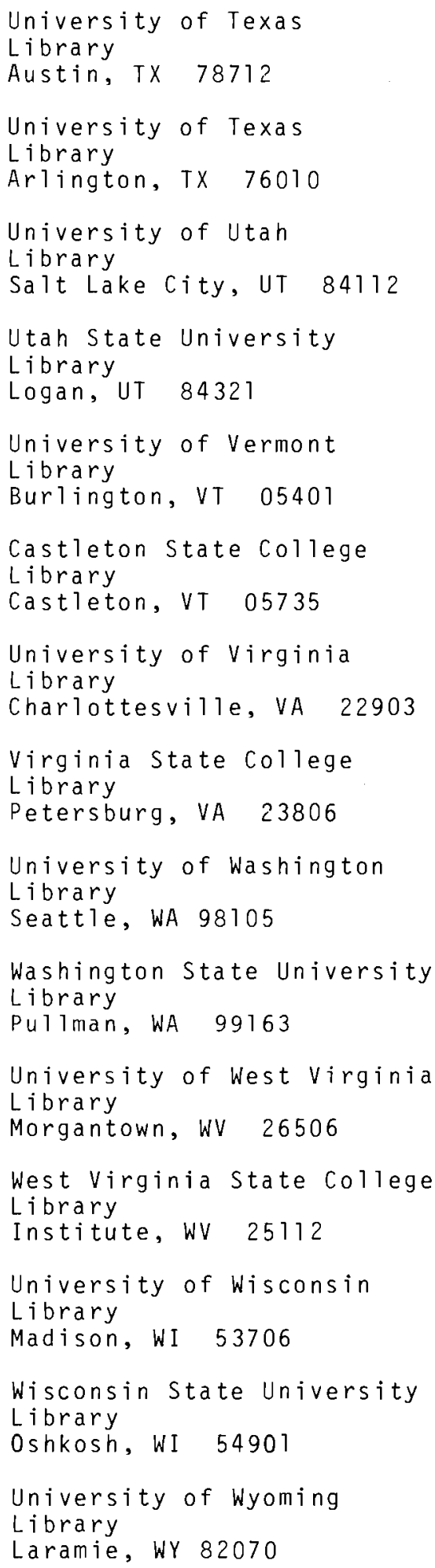




\section{STATE CAPITAL LIBRARIES}

Alabama State Library

Dept. of Archives \& History

500 Adams Avenue

Montgomery, AL 36104

Alaska State Library

P. 0. Box 1541

Juneau, AK 99801

Arizona State Library

Dept. of Library \& Archives, Regiona 1

Phoenix, AZ 85007

Arkansas Supreme Court Library

Little Rock, AR 72201

California State Library, Regional

Sacramento, CA 95809

Colorado State Library

Denver, CO 80203

Connecticut State Library

Hartford, CT 06103

Delaware State Law Library

Dover, DE 19901

Florida State Library

Tallahassee, FL 32304

Georgia State Library

Atlanta, GA 30303

Hawai i State Library

Honolulu, HI 96813

Idaho State Law Library

Boise, ID 83706

Illinois State Library, Regiona 1

Springfield, IL 62706

Indiana State Library, Regional

Indianapolis, IN 46204

Iowa State Traveling Library

Des Moines, IA 50319

Kansas State Historical Society, Library

Topeka, KS 66612

Kentucky State Law Library

Frankfort, KY 40601

Louisiana State Library

Baton Rouge, LA 70803

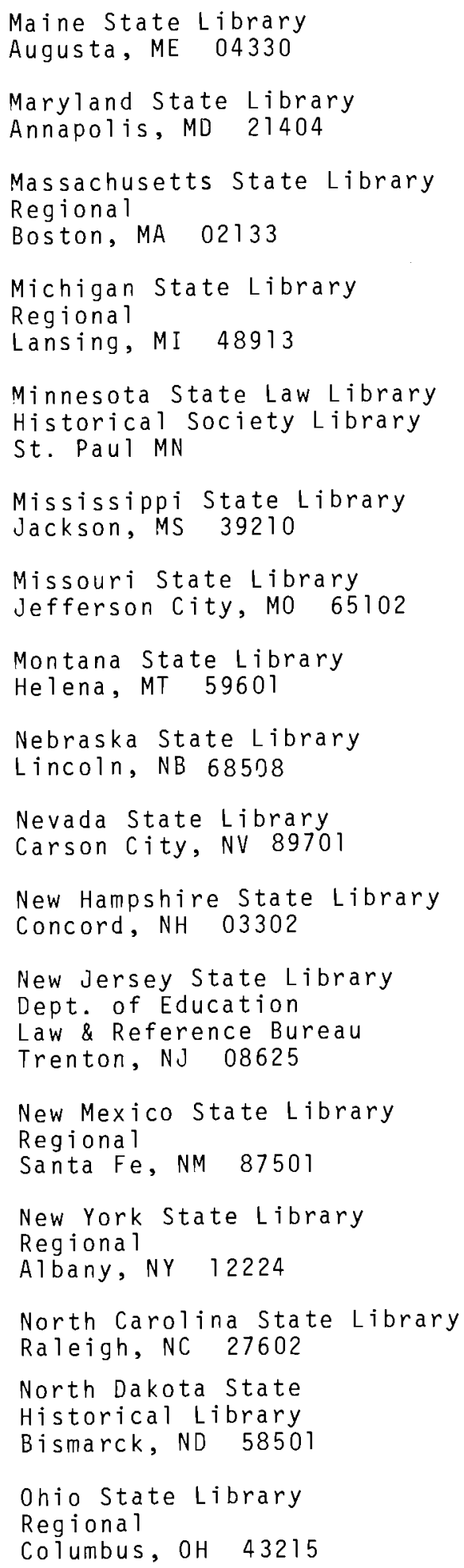




\section{STATE CAPITAL LIBRARIES}

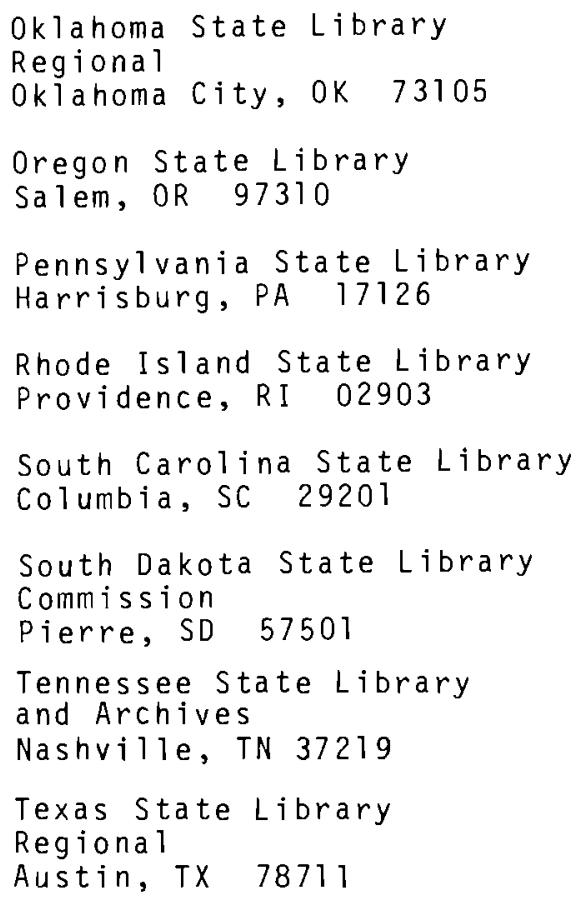

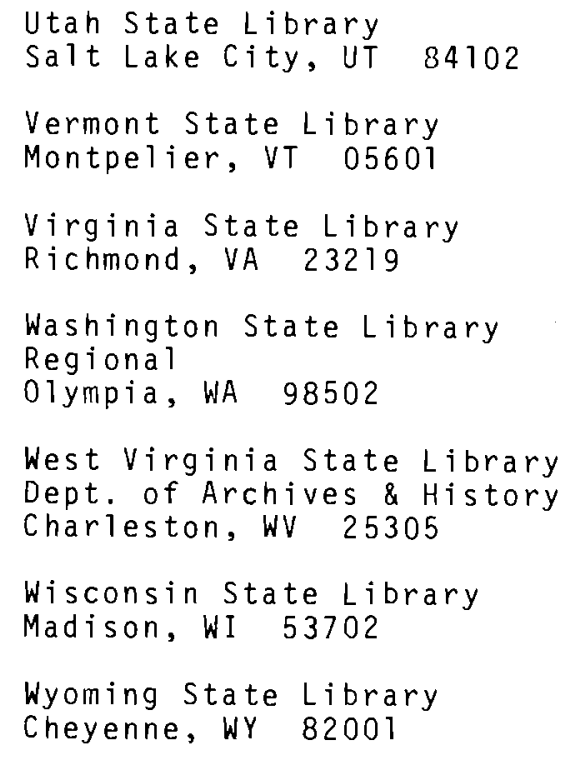




\section{MAJOR CITY LIBRARIES}

Birmingham Public Library 2020 Seventh Avenue North Birmingham, AL 35203

Alaska State Court Libraries 941-4th Avenue Anchorage, AK 99501

University of Arizona

Institute of Atmospheric Physics

Library

Tucson, AZ 85721

Arkansas (State) Library Commission 506-1/2 Center Street

Little Rock, AR 72201

Los Angeles Public Library

630 West Fifth Street

Los Angeles, CA 90017

San Francisco Public Library

Civic Center

San Francisco, CA 94102

Academy Library

U.S. Air Force Academy, CO 80840

Hartford Public Library

Hartford, CT 06103 .

Wilmington Institute Free Library

Wilmington, DE 19801

Washington Public Library

washington, DC 20001

Miami Public Library

Miami, FL 33132

University of Tampa Library

Tampa, FL 33606

Savannah Public Library

Savannah, GA 31401

Municipal Reference Library Honolulu, Hawaij 96813

Boise Public Library

Boise, ID 83706

Chicago Public Library

78 East washington Street

Chicago, IL 60602

John Crerar Library

Chicago, IL 60616

Fort Wayne Public Library

Fort Wayne, IL 46802
Des Moines Public Library

Des Moines, IA 50309

Wichita State University Library Wichita, KS 67208

Louisville Free Public Library

Louisville, KY 40203

New Orleans Public Library

New Orleans, LA 70140

Portland Public Library

Portland, ME 04101

Johns Hopkins University Library Baltimore, MD 21218

Massachusetts Institute of

Technology Library

Cambridge, MA 02138

Detroit Public Library

Detroit, MI 48208

Minneapolis Public Library

Minneapolis, MN 55401

Mississippi Library Commission

Jackson, MS 39201

Kansas City Public Library

Kansas City, MO 64110

St. Louis Public Library

st. Louis, MO 63103

Eastern Montana College Library

Billings, MT 59101

Omaha Public Library

Omaha, NB 68102

Manchester City Library

Manchester, NH 03104

Newark Public Library

Newark, NJ 07101

New Mexico State University

Library

University Park, NM 88070

New York Public Library

New York, NY 10018

Public Library of Charlotte

Charlotte, NC 28202

Fargo Public Library

Fargo, ND 58103 


\section{MAJOR CITY LIBRARIES}

Cleveland Public Library

Cleveland, $\mathrm{OH} 44114$

Cincinnati Public Library

Cincinnati, $\mathrm{OH} 45202$

Toledo Public Library

Toledo, $\mathrm{OH} 43624$

University of Tulsa Library

Tulsa, OK 74104

Reed College Library

Portland, OR 97202

Carnegie Library of Pittsburgh

Pittsburgh, PA 15213

Providence Public Library

Providence, RI 02903

Charleston College Library

Charleston, SC 29401

Carnegie Free Public Library

Sioux Falls, SD 57101

Public Library of Nashville \& Davidson County

222 Eighth Avenue North

Nashville, TN 37203
Dallas Public Library

Dallas, TX 75201

Houston Public Library

Houston, TX 77002

Brigham Young University Library

Provo, Utah 84601

Virginia Polytechnic Institute

Carol Newman Library

Blacksburg, VA 24061

Seattle Public Library

seattle, WA 98104

Spokane Public Library

Spokane, WA 99201

Marshall University Library

Huntington, WV 25701

Milwaukee Public Library,

Regional

Milwaukee, WI 53233

Natrona County Public Library

Casper, WY 82601 